No. 84

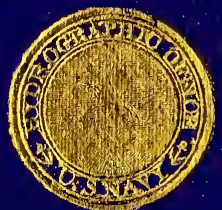

W]ITI COAST

OF

\title{
MEXICO AND CENTRAL AMERICA
} FROM

THE UNITED STATES TO PANAMA INCLUDING

THE GULFS OF OALIPORNIA AND PANAMA

BHCOND WITION 
U. $\mathfrak{s}$. Mational Inuseum

Qtis O. Aleason, Curator of the Division of Bthnolagy alccesgion พro...180690

c 
(1. 


No. 84.

UNITED STATES HYDROGRAPHIC OFFICE,

BUREAU OF NAVIGATION, NAVY DEPARTMENT.

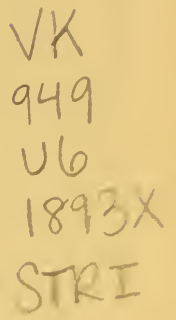

WEST COAST

$\rightarrow \quad \mathrm{OF}$

\section{MEXICO AND CENTRAL AMERICA, \\ FROM}

THE UNITED STATES TO PANAMA,

INCLUDING

THE GULFS OF CALIFORNIA AND PANAMA.

SFCOND FDITION.

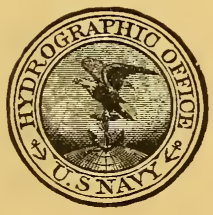

WASHINGTON:

GOVERNMENT PRINTING OFFICE.

I 893. 



\section{CONTEN T S.}

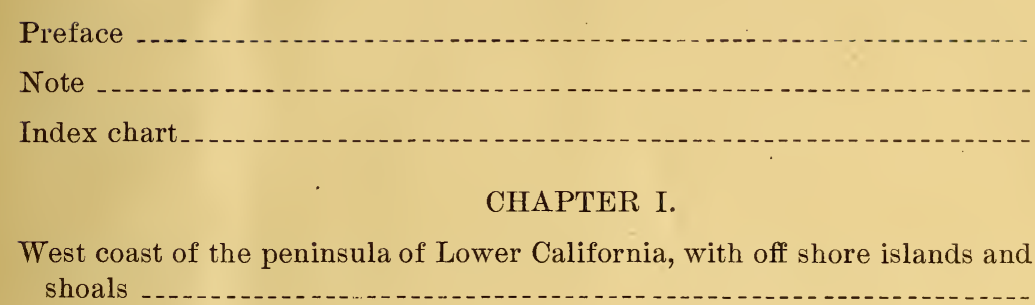

\section{CHAPTER II.}

The gulf of California.--East coast of the peninsula of Lower California --

\section{CHAPTER III.}

The coast of Mexico and adjacent islands from the mouth of the Colorado river to cape Corrientes.

\section{CHAPTER IV.}

The coast of Mexico from cape Corrientes to the Ocos river

\section{CHAPTER V.}

The coasts of Guatemala and San Salvador

\section{CHAPTER VI.}

The gulf of Fonseca and the coast of Nicaragua

CHAPTER VII.

The coast of Costa Rica

\section{CHAPTER VIII.}

The coast of Colombia from Burica point to Garachine point, including the gulf of Panama 



\section{P R E F A C E.}

The present edition of the work has been compiled by R. C. Ray, U.S. Navy, from the following sources, viz:

First edition by Lieut. Samuel Belden, U. S. Navy.

Second edition by Lieut. F. E. Sawyer, U. S. Navy.

Notes and surveys of-

Commander Dewey and officers of U. S. S. Narragansett, 1873 to 1875.

Commander Philip and officers of U. S. S. Tuscarora, 1878 to 1880.

Commander Philip and officers of U. S. S. Ranger, 1881 to 1883.

- Commander Clark and officers of U. S. S. Ranger, 1883 to 1886.

Commander F. A. Cook and officers of U. S. S. Ranger, 1887 to 1889.

Commander G. C. Reiter and officers of U. S. S. Ranger, 1889 to 1890. The latest U. S. Hydrographic Office charts.

Archives of the U. S. Hydrographic Office.

Remarks, etc., between San Francisco and Panama by Captain Wm. H. Parker.

Pacific Mail Steamship Company.

Consular Reports, U. S. State Department, and special reports from U. S. Consuls made to the U.S. Hydrographic Office especially for this publication.

North Pacific Ocean Directory, Findlay.

North Pacific Pilot, Imray.

And late reports from officers cruising on U. S. vessels of war.

RICHARDSON CLOVER, Lieutenant-Commander U. S. Navy,

U. S. Hydrographic - OfFice, Hydrographer.

Washington, D. C., March 31 , 189:3. 
The bearings, courses, and trend of the land are true; but for convenience the corresponding magnetic bearings, to the nearest degree, follow in brackets. [Variation in 1892.] The direction of the winds, the point from which they blow; of currents, the point toward which they set. Distances are expressed in nautical miles. Soundings, unless otherwise stated, are reduced to mean low water.

(vr) 



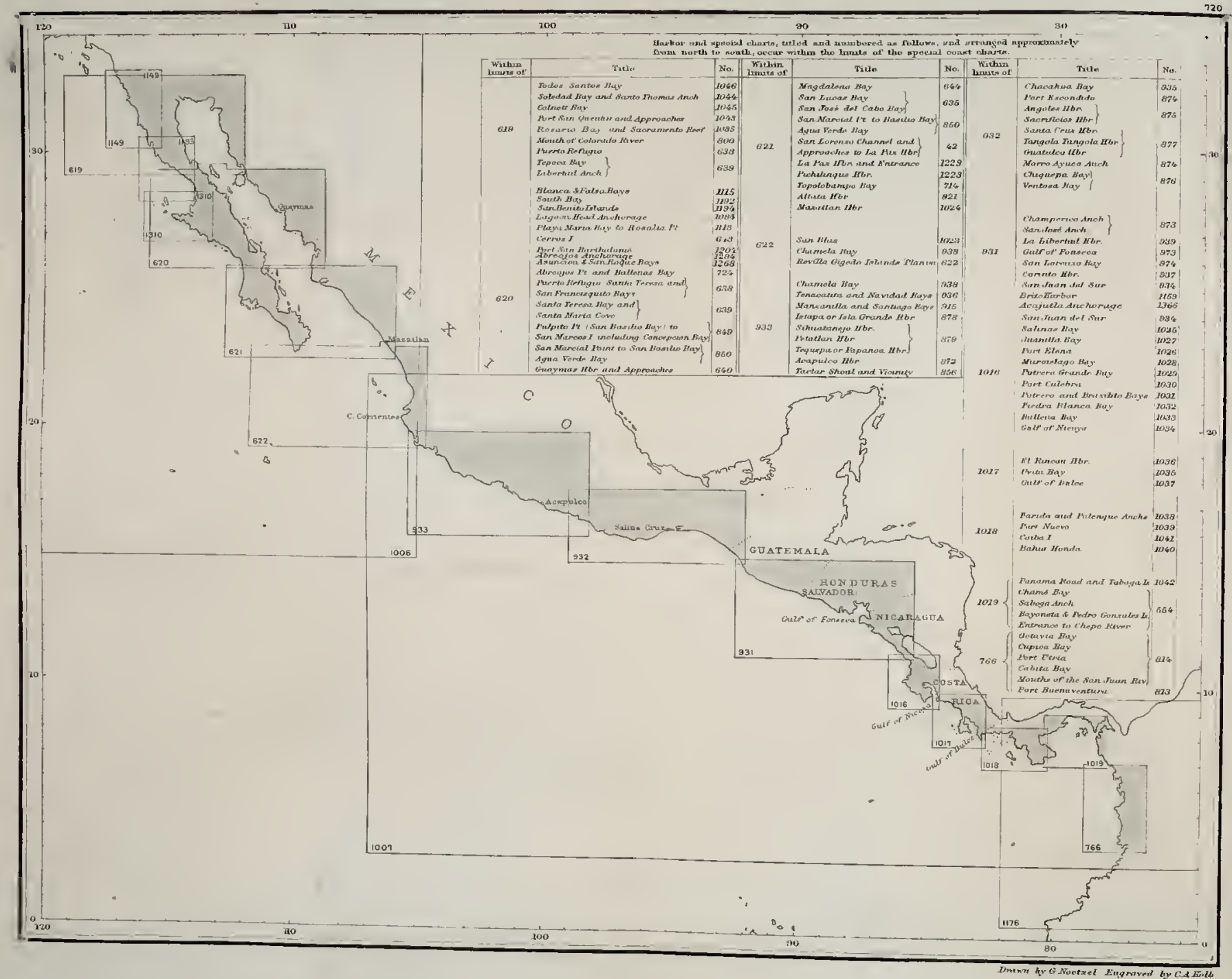







Drawn by G.Noetxel. Engraved by C.A Kolb 
WEST COAST OF THE PENINSULA OF LOWER CALIFORNIA, WITH OFFSHORE ISLANDS AND SHOALS.

Remarks.-The entire coast of the peninsula of Lower California, from the boundary line to cape San Lucas is, with the exception of the valleys of Santo Tomas and Todos Santos, barren in the extreme. The land is generally high and bold, but there are many places where vessels may anchor and find shelter from the prevailing coast wind.

Winds.-The prevailing winds along the coast are from a northe ${ }^{W}$ tsterly direction, and they may be said to blow steadily from that direction for eight months of the year. During the months of November, December, January, and February, winds from SE. to SW. will be frequently met with, and during these months moderate SE. gales, accompanied with considerable rain, will be occasionally encountered. Before the breaking of these gales the wind hauls to the SW. and sometimes blows quite hard for a few hours, then comes out from the NW. with fine weather. In December and January heavy Northers are liable to occur; these winds blow from north to NE. and last from one to three days. During the summer months strong SE. gales of short duration occur in the vicinity of cape San Lucas, sometimes extending as far north as Magdalena bay.

Weather, fogs.-During the greater part of the year the weather along the coast is clear and pleasant, and the climate salubrious and mild ; rains are most frequent between May and October. Fogs occur at all seasons of the year, the largest proportion, however, during the summer months; they usually occur at night or early in the morning and clear up about 10 o'clock in the forenoon, the remainder of the day being clear and pleasant. South of Cerros island there is much less fog than north of it, the weather clears earlier in the forenoon, the temperature is lower, and the winds lighter.

Currents.- The currents along the coast set in the direction of the prevailing wind and vary in strength from half to one knot an hour. Near the land the influence of the tides is felt. At all times an easterly set should be guarded against. A light NW. current has occasionally been found in the winter season, but it is rare.

Boundary monument.-The initial point of the boundary line between the United States and Mexico is marked by a white marble obelisk about 20 feet high, resting on a pedestal. It stands on a low table land near the edge of a bluff, about 300 yards from the beach, and is visible from the 
water. Its position, as determined by the United States Coast Survey in 1871 , is latitude $32^{\circ} 31^{\prime} 58^{\prime \prime} .46 \mathrm{~N}$., longitude $117^{\circ} 07^{\prime} 32^{\prime \prime} .37 \mathrm{~W}$., about $10 \frac{2}{10}$ miles S. $36^{\circ} 30^{\prime} \mathrm{W}$. from point Loma lighthouse.

Los Coronados.-The Coronados islets are a group of barren rocks of trap formation lying about 7 miles off the coast and extending about 5 miles in a NW. and SE. direction. The southerumost is the largest and is 2 miles long by $\frac{1}{2}$ mile in width; it is wedge-shaped, and its highest peak is 674 feet above the sea level. On the west and NW. sides of the southern islet, at a distance of $\frac{3}{4}$ and $\frac{1}{2}$ mile respectively, are two barren rocks about 50 feet high that are a favorite resort for the enormous sea elephants that frequent this coast. N. $63^{\circ} \mathrm{W} .\left(\mathrm{N} .76^{\circ} \mathrm{W}\right.$. mag.) from the northern end of the largest islet, at a distance of $2 \frac{1}{2}$ miles, lies the north westernmost of the group, a barren rock about 1,400 yards in length and 350 feet high. Between this islet and the others is a passage with from 18 to 50 fathoms water and numerous patches of growing kelp.

Anchorage.-A fair anchorage can be found on the east side of the largest islet, a little south of its center, in 8 fathoms of water, sandy bottom. Boats may safely land in a small cove near the anchorage, which is open to the northward.

Coast.-From the boundary monument the coast trends nearly south 5 miles; thence SSE. to Descanso point, it is generally bluff from 50 to 80 feet high. A ferw miles inland is a range of hills about 400 feet in height, and back of these a range of mountains, one of which, Table mountain, is 2,230 feet high, and another, a triple-peaked mountain, a few miles south of Table mountain, called Sharp peak, is 2,700 feet high. They are easily distinguished, and are excellent land marks in approaching the coast.

Four miles north of Descanso point are a ranch and an arroyo, off which are some outlying rocks at a short distance from the shore.

Descanso bay.-From Descanso point the coast turns sharply to the eastward for about 3 miles, and then curves gradually around to the southward, forming Descanso bay. Three and a half miles S. $52^{\circ}$ E. (S. $65^{\circ}$ E. mag.) from Descanso point is the Sugarloaf rock, a small rock about 15 feet high, which is the only outlying danger in the bay. There is an anchorage to the southward of it, often used by the small coasters, and anchorage may be found anywhere along the shore of the bay in from 8 to 15 fathoms, sand bottom. At $6 \frac{1}{2}$ miles southeastward of Descanso point is a small settlement near the shore, which may be recognized by conspicuous sand hills to the northward of it. Small vessels frequently anchor near it.

Sal si puedes point is low and not well defined. It is 16 miles S. $27^{\circ}$ E. (S. $40^{\circ}$ E. mag.) from Descanso point. The intermediate coast is generally sandy, with an occasional rocky cliff and high hills rising immediately back of the beach. 
Cape San Miguel is the northern limit of Todos Santos bay, and is a bold point 150 feet high. It bears S. $40^{\circ}$ E. (S. $53^{\circ}$ E. mag.) from Sal si puedes point, and is $10 \frac{1}{2}$ miles distant from it. The intermediate coast consists of alternate sand bluffs and rocky cliffs about 50 feet high, backed by hills of from 300 to 500 feet in height, and a mountain range of 2,000 feet and upwards a few miles inland. This latter has the appearance, to a person a few miles at sea, of bordering on the coast.

Enşenada point is S. $62^{\circ}$ E. (S. $75^{\circ}$ E. mag.) of cape San Miguel, at a distance of $6 \frac{1}{4}$ miles; it is a steep hill 370 feet high. The coast between them is bold, with cliffs from 50 to 100 feet in height. A large field of kelp extends from $2 \frac{1}{2}$ to 3 miles off the point to the westward, having from 13 to 16 fathoms water at its southern edge.

Ensenada anchorage.-From Ensenada point the coast turns sharply to the northward and eastward for about $\frac{1}{2}$ mile, forming a snug anchorage, where vessels may lie in from 3 to 5 fathoms water, sand bottom, sheltered from all winds except those from the SW. The soundings have decreased slightly since 1873 , caused by the streams in the wet season washing into the anchorage the light soil from the hillsides. The point affords partial shelter from the $\mathrm{NW}$. winds, except in the winter, when a heavy swell sets in. Ensenada, the seat of government of the northern district of Lower California, is a port of entry. The population is 800 . The place is improving rapidly in importance under the influence of the International Company of Mexico. Cattle raising is carried on to a considerable extent and wheat is raised. There are two flour mills and more are contemplated. The town is kept very clean, but there are no sanitary regulations. No hospitals, but two doctors. Freight and passengers are landed on a pier some 2,000 feet long. Vessels load and unload by means of lighters.

The United States is represented by a consular agent.

Supplies.-Provisiors are plentiful and fairly cheap. Water is plentiful. No coal.

Steamers.-Pacific mail steamers call once a month.

Telegraph.-There is telegraphic communication with all parts via San Diego.

Port charges.-Tonnage dues free to steamers; sailing vessels $\$ 1.50$ registered ton. Captain of port and stamps, $\$ 4$. Bill of health, $\$ 4.25$. Stamps for permit to discharge, $\$ 8$. Sailing vessels when in ballast or bringing coal are also free of tonnage dues.

Pilots.-CThere is one official pilot. Chäges, $\$ 3.50$ per foot. Each time of changing moorings, $\$ 4$.

All of the above in Mexican money.

Todos Santos bay.-From Ensenada anchorage the land sweeps around in a semicircle to Banda point, which is a bold rocky headland 500 feet high, forming the southwestern limit of Todos Santos bay. At the bottom 
of the bay is a low sand beach, about $2 \frac{1}{4}$ miles in extent, flanked on the north by a range of hills 500 feet high, and on the west by the cliffs of Banda point. A number of detached rocks line the southern shore of the bay, and a rocky ledge extends about $\frac{3}{4}$ mile to the northward and west ward from Banda point. Numerous patches of kelp are found in the bay and lining the beach.

Todos Santos islands lie northwestward from Banda point, the southeastern end of the southernmost and larger of the two being about 3 miles distant from it. From this point they extend about 2 miles in a northwesterly direction. The southernmost is about $1 \frac{1}{4}$ miles long, less than $\frac{1}{2}$ mile wide, and 313 feet high. Between it and Banda point there is a clear channel 2 miles wide. The northernmost island is about $\frac{1}{2}$ mile long, $\frac{1}{4}$ mile wide, and from 30 to 55 feet high. Both are barren, and surrounded by detached rock and kelp. There is a boat passage between them, and anchorage may be found in good weather on the northeastern side of the larger one in 10 fathoms, sand bottom.

Santo Tomas point lies 12 miles S. $14^{\circ}$ E. (S. $27^{\circ}$ E. mag.) of Banda point. The coast between them is in crescent form, high and precipitous, with deep water close to the shore, and numerous detached outlying rocks. The point itself is low and rocky, rising abruptly to a height of 395 feet where it unites with the coast range, which attains at a few miles from the coast a height of 3,500 feet.

Soledad rocks lie one mile westward of Santo Tomas point. They are 20 feet high, small in extent, and surrounded with kelp. There is deep water around them. There is a channel between the rocks and Santo Tomas point; with no known dangers. In passing through it care should be taken to keep clear of the kelp on either side.

Santo Tomas anchorage.-Half a mile to the southward of Santo Tomas point the coast makes a sharp turn to the eastward, forming a small bight, where good anchorage may be found in from 5 to 10 fathoms, sandy bottom, sheltered from the prevailing coast winds. It is the shipping point for the village of Santo Tomas. No sign of fresh water could be found. The village of Santo Tomas is 11 miles from the anchorage. There are no buildings at present near the landing.

Directions.-When making for the anchorage from the northward or westward give the land to the southward of Santo Tomas point a berth of from $\frac{1}{4}$ to $\frac{1}{2}$ mile, to avoid the dense masses of kelp found there; stand to the eastward until a small sand beach, with a few outlying rocks at its southern end, to the northward of the inner point, is open; then haul up to the northward and anchor as soon as the Soledad rocks are shut in. Coming from the southward steer for the deepest bight until the small sand beach is made out; then follow directions given above. This will 
place you in from 7 to 8 fathoms water, sand bottom, within $\frac{1}{4}$ mile of the landing place, which is on the small strip of sand beach.

Coast.-The coast between Santo Tomas point and cape Colnett recedes considerably and is a succession of broken bluffs and low beaches to within 10 miles of cape Colnett, where the perpendicular cliffs commence and extend around the cape. A patch of kelp extends about $2 \frac{1}{2}$ miles off San José point, but not less than 13 fathoms water were found in it. Twentyone miles below point Santo Tomas, behind the larger of two detached rocks, white from the deposit of birds so that they can be seen 5 or 6 miles, is a good landing place for boats. From here is a road. to San Vincente. The mission is 7 miles inland. There is a rocky patch 1,200 yards off shore just above the mouth of the San Ysidro river. These are the only known dangers from Santo Tomas point to cape Colnett.

Cape Colnett is a perpendicular cliff 100 to 250 feet high. On a base of light sandstone, 50 feet or more above the level of the sea, lies a strata of broken rock, nearly black and strongly resembling coal, the same being covered with sand. " The coast retains the same characteristics for nearly 10 miles to the northward.

Colnett bay.-From cape Colnett the coast trends to the northward and eastward about $2 \frac{1}{2}$ miles, forming Colnett bay, where good anchorage may be found abreast of a remarkable gorge, in from 6 to 9 fathoms water, sand bottom. The best landing place is at the intersection of the cliffs and the shingle beach at the bottom of the bay.

San Ramon bay.- South of cape Colnett the coast sweeps around to the eastward, forming what is called on the charts San Ramon bay, the land is lower than to the north of the cape, and consists of sand hills. For a distance of 15 or 18 miles after leaving the anchorage, fields of kelp make off from the shore about 3 or 4 miles, thence to abreast San Martin island the coast is clear, the water is shoaler than northward of the cape, but there are apparently no outlying dangers.

San Martin island lies 30 miles S. $24^{\circ}$ E. (S. $37^{\circ}$ E. mag.) of cape Colnett. It is nearly circular in form, having its greatest diameter ( $1 \frac{1}{2}$ miles) in an east and west direction. There are two remarkable peaks near the center, the westernmost of which, 471 feet high, is an extinct volcano, having a crater at its summit 350 feet in dianeter and 40 feet deep. The island is quite barren, producing nothing but the prickly pear and a few stunted bushes that grow among the loose masses of lava.

Anchorages.- There is a good anchorage on the SE. side of the island, off a small lagoon which has communication with the sea at half tide, and anchorage may be found anywhere on the NE. side. The best place to anchor is in Hassler cove, a snug little bight on the eastern side of the island, protected on all sides except the north. Anchor in from 7 to 9 fathoms, the northern end of the natural breakwater that forms the east 
side of the cove, bearing S. $57^{\circ}$ E. (S. $70^{\circ}$ E. mag.) During a southerly gale at this anchorage it is well to drop an anchor under foot in case of change of wind from SW. to NW. The island is surrounded by detached rocks and kelp, and great numbers of seal and sea fowl resort to it, particularly to the shores of the cove and lagoon.

Ben rock.-A dangerous rock, known as Ben rock, with from 9 to 12 feet water over it, lies $2 \frac{5}{8}$ miles southward of San Martin island, $4 \frac{1}{8}$ miles from the main land.

There are 11 fathoms water close to the rock and 25 fathoms 200 yards from it. There is no kelp surrounding this rock, and the sea only breaks on it occasionally in moderate weather.

Channel.-Between San Martin island and the main land there is a passage about $2 \frac{1}{2}$ miles wide, with from 10 to 15 fathoms of water, apparently free from danger.

Coast. - At the southern extremity of San Ramon bay and nearly abreast of San Martin island the coast rises suddenly in a perpendicular cliff of dark-colored rock; thence the coast is a low sand beach for a short distance, then bold rocky cliffs to Southwest hill (one of the five hills of the early navigators), which is 380 feet high and borders directly on the sea. From Southwest hill to Reef point is a low sand beach backed by sand hills.

Mount Calamahue, 10,126 feet high, is visible from this vicinity.

Reef point is the northernmost of a serics of rocky points extending out from the southern extremity of the peninsula that forms the western side of port San Quentin. A reef extends off from the point to the westward about $\frac{1}{4}$ mile. A like reef extends from a point $\frac{1}{2}$ mile to the northward of Reef point.

From Reef point to cape San Quentin the coast is low and rocky, with numerous projecting points and outlying rocks over which the sea breaks heavily. There is a short strip of sand beach, about 200 yards in length, just west of cape San Quentin, and Afuera point, which is the southernmost point of land, lies 600 yards to the westward. From cape San Quentin the low rocky beach continues for a little more than $\frac{3}{8}$ mile to the northward and eastward, thence to Entrada point is a low sand beach with one projecting rock 300 yards SW. of the point.

Entrada point is a low rocky point with no outlying dangers; it may be approached from the eastward to within 200 yards by a vessel drawing 18 feet; from any other direction it is not safe to approach it within $\frac{1}{4}$ mile. Half a mile northwestward of Entrada point is a low sandy point called Sextant point. The beach between them is low and sandy, and recedes about 400 yards, forming a small bight in which the water is shoal.

Port San Quentin is a small, perfectly secure anchorage, protected on every side; the land in the vicinity is low and sandy, and with the excep- 
tion of the cactus and a few stunted bushes, entirely without vegetation. No fresh water can be found near the coast.

Five hills.-To the northward of the port are five remarkable hills, which caused one of the early navigators to give it the name of the "Bay of Five Hills." When approaching the coast from the northward these hills have the appearance of islands.

Caution.-No vessel should attempt to enter port San Quentin without either sending a boat ahead to sound or buoying the channel, which is narrow and tortuous and liable to change with every southerly gale.

San Quentin bay.-From port San Quentin the coast trends to the eastward for 7 or 8 miles and then turns to the southward, forming San Quentin bay. The water is shoal for several miles off shore, and a long swell will usually be found rolling in, making it an uncomfortable anchorage. The shore of the bay is a low sand beach, with hills about 300 feet high rising a short distance inland, backed by a mountain range of from 1,500 to 4,000 feet in height. About 10 miles from cape San Quentin, where the coast assumes a southerly direction, its character changes, sand bluffs and dark-colored cliffs alternating for several miles, and gradually decreasing in height as they approach Baja point.

Baja point, which is situated $26 \frac{3}{4}$ miles S. $20^{\circ}$ E. (S. $33^{\circ}$ E. mag.) from San Quentin, is a low sand cliff about 30 feet high ; $5 \frac{1}{2}$ miles to the northward of it is a ranch lying in a small indentation of the coast between a dark-colored hill, 409 feet high, and an arroyo. A reef surrounded by kelp makes off a short distance to the southward of the point, and vessels entering Rosario bay should give it a gord berth.

Rosario bay.- From Baja point the coast turns abruptly to the eastward, forming Rosario bay, so called from the old mission of Rosario, which is situated in a fertile valley a few miles inland.

Anchorage.-Safe anchorage may be found in the bay in from 5 to 6 fathoms, sandy bottom, sheltered from the usual coast wind.

From Rosario bay to San Antonio point the coast is of sand bluffs 50 to 100 feet high, with hills from 300 to 500 feet in height $1 \frac{1}{2}$ to 2 miles back from the beach.

San Geronimo island.-The northernmost point of San Geronimo island lies $9 \frac{1}{4}$ miles southward of Baja point. It is a barren rock, covered in many places with a mixture of sand and guano, $\frac{3}{4}$ mile long and less than $\frac{1}{3}$ mile wide, with rocky beaches and cliffs 10 to 20 feet in height. Near the center is a peak 130 feet high; northward of this are two lower ones. A reef extends $\frac{1}{2}$ mile off the southeru extremity of the island, its termination being marked by a rock above water, over which the sea breaks heavily, and the whole island is surrounded by outlying rocks and kelp. There are several rocky patches in the kelp, inside a line joining Geronimo island and Baja point. 
Anchorage.-There is an anchorage to the eastward of the island in about 7 fathoms, sand bottom, but an uncomfortable swell will usually be felt. 'A good landing place will be found on a small shingle beach, in a slight indentation of the shore line on the SE. side of the island, at the base of the highest peak.

Sacramento reef lies southeastward of San Geronimo island, and is very dangerous. The channel between them is about 2 miles in width, with from 11 to 15 fathoms water in the center. The reef is a little more than 2 miles in extent from $\mathrm{NW}$. to SE. and $\frac{1}{2}$ mile wide; there are several large rocks awash and above water, over which the sea breaks constantly.

Caution.-The U.S. S. Ranger observed heavy breakers in the ketp both north and SE. of Geronimo island. These breakers were only observed once during several passages inside the island and Sacramento reef.

In the'passage between the reef and San Geronimo island and in that between them and the main land there are large, dense masses of kelp which should always be avoided if practicable, as there are many rocky patches in this vicinity, and although no hidden dangers have been found, vessels should proceed with great caution while in these passages.

Coast.-From San Antonio point the coast trends S. $52^{\circ}$ E. (S. $64^{\circ}$ E. mag.) to Canoas point, retaining its character of sand bluffs varying in height from 50 to 100 feet, backed by moderately high hills and in some portions by table lands from 1,000 to 2,000 feet high, of which Sombrero peak, lying about $2 \frac{1}{2}$ miles to the NE. of Bluff point, is the most conspicuous and is 1,968 feet in height.

Bluff point is a bold sand bluff 100 feet high, lying $18 \frac{3}{4}$ miles in a southeasterly direction from San Antonio point, between it and a remarkable gorge, 3 miles to the southward of the latter, is a large field of kelp which extends about 5 miles off shore; 12 fathoms water was found in this field at a distance of 4 miles from the land, bottom sand and rock. From Bluff point the coast recedes somewhat, forming an indentation between it and Canoas point.

Canoas point is a sharp perpendicular sand bluff 224 feet high, surrounded by hills of from 700 to 1,200 feet in height, which are backed by a mountain range of 2,000 feet or more.

Anchorage.-An anchorage partially protected from the coast winds will be found under the lee of the point in good weather in from 5 to 7 fathoms water, sand bottom, about $\frac{1}{2}$ mile from the shore.

Coast.-Blanca point lies 33 miles S. $53^{\circ}$ E. (S. $64^{\circ}$ E. mag.) of Canoas point. The coast between them recedes somewhat and is composed of sand bluffs and rocky points alternating with low sand beaches. From seaward three distinct mountain ranges are visible on this part of the coast. The first or coast range being from 500 to 1,000 feet in height; the second, back 
of the first, 2,000 feet high, and the third rises back of the second to a height of 3,000 feet and upwards.

Solitary rock is about 20 miles to the southward and eastward from Canoas point, and $\frac{1}{2}$ mile from shore. It is surrounded by kelp; large quantities of drift weed were found on the beach in the vicinity of this rock.

Cone point is S. $35^{\circ}$ E. (S. $46^{\circ}$ E. mag.) $10 \frac{1}{2}$ miles from Blanca point; it is a steep rocky point, with a reef of rocks extending to the southward $\frac{1}{4}$ mile.

Blanca bay.-The coast between Blanca point and Cone point recedes and forms this bay. A good anchorage may be found here protected from the prevailing coast wind. Just north of Cone point is a conspicuous hill of reddish color called Red cone. When first seen from the northward it has the appearance of an island.

Falsa bay is formed by an indentation in the coast to the southward of Cone point ; its shores are quite low and consist of sand and shingle beaches to within $1 \frac{1}{2}$ miles of Maria point, thence to the point it is steep and rocky. At the bottom of the bay is a wide arroyo, with sand hills on either side. There is anchorage in the northern part of the bay, in from 4 to 6 fathoms, pretty well protected from the usual coast winds.

Maria point, which forms the southern limit of Falsa bay, is low and rocky, with sand hills $\frac{1}{4}$ mile to the northward.

Sebastian Viscaino bay.-From Maria point the coast sweeps around to San Eugenio point in an almost unbroken curve, and with Cerros island on the west forms the great bay of Sebastian Viscaino. The eastern coast of this bay is for the most part low and sandy, with extensive marshes; high mountain ranges being visible far in the interior. The south coast has the same character until within a few miles of False point, when the bluffs become high and the mountains approach the coast. Nearer San Eugenio point the character of the coast changes, rocky formation predominating and forming a steep rocky point called False point. Sharks are abundant, wherever the water is shoal, and many other varieties of fish are plentiful. The great Jew fish attains here a weight of from 100 to 400 pounds. Within the limits of this great bay are several smaller bays and anchorages, a detailed description of which follows.

Playa Maria bay is formed by a sweep in the coast line between Maria point and Black point. Its shores are low, sandy, and barren. A few miles inland there is a little vegetation and some small game. On the northern shore of the bay is a cone-shaped hill, 236 feet high, called Station peak. There is anchorage in the northern part of the bay in 6 or 7 fathoms, sand bottom, where vessels may lie, protected from the prevailing: coast wind. A swell usually sets in rendering the anchorage uncomfortable. 
Black point, which forms the southern limit of Playa Maria bay, is a steep rocky point with a hill 609 feet high rising close to it.

Rocky point is a steep cliff, and is the abrupt termination of a ridge of high hills running at a right angle to the coast line; $1 \frac{1}{2}$ miles from the point in a northeasterly direction is a conspicuous conical hill. In clear weather the high peaks of Cerros island, 60 miles distant, are visible from this vicinity.

The coast for $3 \frac{1}{4}$ miles to the southward and eastward of Rocky point is bold and rocky with cliffs 50 feet high; thence to Elide island it consists chiefly of low sand beaches, with hills of moderate height rising a short distance inland.

Elide island is a barren rock 600 yards in length, about 40 feet high, and covered with a thin layer of guano. It is a favorite resort of seals and sea fowl. A sand spit or bar, over which the sea breaks, connects it with the main land, from which it is about $\frac{1}{2}$ mile distant.

Vessels sometimes anchor on the SE. side of the island, but the anchorage is not recommended, as a heavy swell usually heaves in there.

Santa Rosalia bay.-From Rosalia point the coast turns sharply to the northward and eastward, forming Santa Rosalia bay, where good anchorage may be found in from 5 to 8 fathoms, sand bottom; sheltered from the coast winds. On the north side of the bay is a shingle beach, where the best landing will be found. Bold, rocky cliffs line the eastern shore, and the southern limit of the bay is marked by a low projecting point with numerous outlying rocks, and a dangerous reef extending $\frac{1}{2}$ mile to the southward and surrounded by kelp. An ample supply of excellent clams was found by the Narragansett's crew, by digging on the beach. No fresh water was found.

South of Santa Rosalia bay the coast falls away about 5 miles, forming a large open bay with bluff shores from 50 to 100 feet high, increasing to 200 feet as Lagoon head is approached. High hills rise a few miles inland and mountain ranges are visible in the interior, the most conspicuous being "High Leaning peak," whose jagged top appears to overhang.

Lagoon head, the Cabo Negro of the old Spanish charts, is a high darkcolored headland of volcanic origin; its highest point is 475 feet above high-water mark, and it can be seen in clear weather from a distance of 30 to 40 miles, having, when first seen from seaward, the appearance of an island.

From Lagoon head the coast makes a sudden turn to the eastward for about 2 miles and then sweeps around to the southward, forming a small open bay which affords good anchorage in from 3 to 8 fathoms, sandy bottom. A good landing place will be found on a sand beach at the foot of the bluffs about 2 miles east of the head. 
Manuela or Upper lagoon is the northernmost of three large lagoons situated near the eastern shore of Sebastian Viscaino bay and communicating with its waters. It is nearly 8 miles long in a north and south direction and about 2 miles wide, a narrow strip of low sand beach interspersed with small hillocks and partially covered with stunted bushes intervening between it and the waters of the bay. The entrance is obstructed by a bar which makes off about a mile and has 5 feet of water over it at low tide. The sea usually breaks on the bar in fine weather, except near high water.

Black Warrior lagoon takes its name from that of a bark which was lost on the bar in 1859. It is about 10 miles long, north and south, and 3 to $3 \frac{1}{2}$ miles wide. The entrance is $7 \frac{3}{4}$ miles to the southward of that of Manuela lagoon, and shoal water makes off from $1 \frac{1}{2}$ to 2 miles. Vessels have crossed the bar drawing 13 feet.

Scammon lagoon is the southernmost and much the largest and most important of the lagoons that open into Sebastian V iscaino bay. It has never been surveyed and opinions differ greatly as to its extent (Captain Scammon, who is perhaps as good authority as any, says that its eastern limit is about 35 miles from the bar, and that it varies from 4 to 12 miles in width); it is studded with low islets and there are numerous sand bars in it, many of which uncover at low tide. A branch known as Fort lagoon extends 8 miles to the southward of the main lagoon and is navigable.

Extensive shoals make off 5 miles from the entrance, which lies $14 \frac{1}{2}$ miles in a southwesterly direction from that of Black Warrior lagoon, and it is marked by white sand bluffs on either side 30 to 40 feet high.

Caution.-No definite directions can be given for crossing the bar, which is constantly changing, and its passage should not be attempted by a stranger without either sending a boat ahead or buoying the channel. It is said that 18 feet have been carried over the bar (probably 12 to 15 feet would be found at ordinary high tides), which is about $\frac{1}{2}$ mile wide, the water rapidly deepening after it has passed to 4,5 , and 6 fathoms. The Narragansett was unable to examine either the channel on the lagoon, as the sea was breaking heavily over the bar during her stay.

The following is from a report by Capt. C. M. Scammon: "Scammon lagoon was first known commercially in 1858. The passage into it is lined on the south side by a continuous line of breakers, forming a curve which extends 4 miles from the head of the harbor, reaching the bar, which has 3 fathoms of water over it at ordinary tides; detached breakers on the north side plainly mark that side of the channel, which is of sufficient width to afford a good beating passage for a vessel of 300 tons, drawing 12 feet. The brig Boston with the schooner Maria as tender, on a whaling and sealing voyage, were the first vessels to traverse this hitherto unknown whaling ground. A good channel is found along the south 
shore, reaching to near the head of the lagoon. To the north of this channel are numerous sand bars and low islets, the latter being the breeding place of seals and sea fowls."

Salt.-Near the head of the lagoon are the salt fields of Ojo Liebre, which are capable of furnishing an almost unlimited supply. Vessels of 400 tons may lie within 5 miles of where it may be put in lighters of from 25 to 50 tons capacity. The surrounding country for miles from the shores of the lagoon is a sandy desert, the only vegetation consisting of dwarfed shrubbery and the ever present cactus. The nearest fresh water is 7 miles distant, and everything for man's subsistence, except fish, turtle, and sea fowl, must be brought from the interior or imported by sea. South and SW. from the lagoon may be seen the high, boulder-like peaks of the Santa Clara mountains.

Chester islets are two rocks 18 feet high, covered with guano. The westernmost lies $\frac{1}{2}$ mile from False point, and has a small outlying rock close to, on the north side. Two-thirds of a mile from the westernmost and $1 \frac{1}{6}$ miles from the point, is the eastern one. The channel between the two islets and that between them and the point is filled with kelp, and, although no hidden dangers were found, it is not recommended to attempt their passage.

Reef.-Half a mile to the north ward of False point is a dangerous reef. It is egg-shaped, $\frac{3}{4}$ mile long by $\frac{1}{2}$ mile in width, and is surrounded by kelp. There is a rock awash nearly in its center, over which the sea breaks heavily. From 7 to 8 fathoms, rocky bottom, were found in the channel between the reef and the point and also between it and the westernmost of the Chester islets.

San Eugenio point is the NW. extremity of the peninsula that forms part of the southern shore of Sebastian Viscaino bay. It lies $1 \frac{3}{4}$ miles from False point, and is a dark, rocky projection surrounded by a reef, which extends about $\frac{1}{4}$ mile from the shore. There is a whaling station in a little cove abont $\frac{1}{2}$ mile to the eastward of the point.

Natividad island, lying to the northwestward of Eugenio point and separated from it by Dewey channel, is about $3 \frac{3}{4}$ miles long NW. and SE., and from $\frac{1}{2}$ mile to a mile wide, being widest at its southeastern end. It is of moderate elevation, its highest point being 502 feet above the sea level, hilly and barren, with mostly steep, rocky shores surrounded by detached rocks and kelp; on the southeastern end is a sand beach about $\frac{1}{2}$ mile lor.s.

Maria rock is $\frac{1}{2}$ mile off the $\mathrm{NW}$. point; it is 15 feet high, and is connected with the island by a reef.

Sail rock lies about 400 yards west of the southern point of the island; a short reef extends off from it to the southward and eastward, on which the sea breaks only at long intervals in fine weather. About $\frac{1}{4}$ mile to the 
eastward of the southern point, connected with it by a reef, is a flat-top rock about 25 feet high, called Flat rock, upon which the sea breakks continually.

There are several reefs making off from the NE. side of the island.

Dewey channel, which lies between Natividad island and San Eugenio point, is about 4 miles wide and may be used with safety if proper care is observed.

On the Natividad side of the channel there is much foul ground and the - soundings are very irregular. One mile S. $79^{\circ} \mathrm{E}$. (east mag.) of Flat rock there is a circular shoal about $\frac{1}{2}$ mile in diameter, with rocky bottom, having 3 fathoms water over it and from 6 to 10 fathoms around it, the sea breaks over it only at long intervals in fine weather.

- For $1 \frac{1}{2}$ miles to the eastward of this numerous shoal spots exist, with from 6 to 7 fathoms over them. On the San Eugenio side there is a clear passage a mile wide, through which, at a distance of about $1 \frac{1}{2}$ miles from the shore, may be carried 17 to 20 fathoms, the kelp on either side plainly marking the channel.

Kellet channel is a deep, clear chanuel $7 \frac{1}{2}$ miles wide, separating Cerros and Natividad islands; from 20 to 30 fathoms may be carried through the center; no obstructions are known to exist.

Cerros island, which forms the western side of Sebastian Viscaino bay, is $21 \frac{1}{4}$ miles long and from 4 miles wide near the center to 9 miles near the southern end. It is of volcanic origin, with numerous high peaks, the highest of which (the Mount Ayres of Dr. Veatch) is 3,955 feet high. In clear weather the peaks of the island may be seen from a distance of 60 miles.

Morro Redondo point is the southeastern extremity of the island, and is a rocky cliff 30 feet high, with numerous outlying rocks to the southward and westward. A round hill (El Morro Redondo) lies just back of it.

Anchorage.-To the northward of Morro Redondo the coast recedes, forming a good anchorage in from 7 to 10 fathoms, sandy bottom, not over $\frac{1}{2}$ mile from the beach. Care must be taken not to let go the anchor too far off shore, as the water deepens suddenly!

Watering place.-About 4 miles to the northward of the anchorage and $5 \frac{1}{4}$ from Morro Redondo is a good watering place, which may be easily recognized by a patch of tall rank grass that lies back of a sand beach about 250 feet in length, and the only one in the vicinity. The course of the stream ends in an arroyo about a mile to the southward of the easternmost point of the island and $\frac{1}{2}$ mile from the beach, where it is lost in the sand.

There is deep water close to the shore, abreast of the watering place. Other fresh water springs are said to exist in some of the ravines to the northward, where landing can be effected. 
East coast.-The whole eastern side of the island north of the watering place is a succession of rocky bluffs and ravines, with short stretches of gravel beach. Back of the shore line the land rises abruptly in sharp ridges and precipitous cliffs to mountain peaks of 3,000 feet and upwards.

The sea on this side is generally smooth, and deep water extends close up to the shore, which is free from kelp. Capt. C. M. Scammon's report contains the following: "On the NE. side, at about 3 miles from the extreme north end, a low sandy point makes out. Southward of this is good anchorage with the prevailing winds."

The northern point of the island is formed by broken bluffs, with many large outlying rocks. A sharp peak, 1,761 feet high, with a comb or crest of cedar trees on it, rises just back of the point.

West coast.-The western side of the island for about 8 miles from the northern point has the same general character as the eastern coast, but the outlying rocks are more numerous and extend farther off shore; thence the coast curves around to the $\mathrm{SW}$. and is an unbroken line of steep cliffs to a point $2 \frac{1}{2}$ miles north of cape San A ugustin. A stony beach fronts these cliffs for the entire distance except about $2 \frac{1}{2}$ miles in the center, where a rocky ledge with outlying rocks extends into the sea.

From the point $2 \frac{1}{2}$ miles north of cape San Augustin a reef of rocks makes off 2 miles in a northwesterly direction; $\frac{1}{2}$ mile from the NW. extremity of this reef is a conspicuous rock called Red rock.

Cape San Augustin is a bold basaltic headland at the southwestern extremity of the island, and is the termination of a range of high hills that is separated from the main range of mountains. There is generally a heavy surf on the whole western side of the island, and there are extensive fields of kelp along the shore of the southwestern part.

South bay.- The character of the southern coast of the island is similar to that of the eastern side. An indentation of $2 \frac{1}{2}$ miles forms what is known as South bay, where anchorage may be had in about 7 fathoms water, close to the shore, and sheltered from the prevailing winds, but open to the southerly gales that sometimes occur during the early part of the winter. On the northern and eastern sides of the bay, sand beaches front the bluffs; on the $\mathrm{NW}$. side there are numerous outlying rocks, extending as much as $\frac{1}{2}$ mile off shore.

From the eastern limit of South bay to Morro Redondo point there are many outlying rocks, and the soundings off shore are very irregular, 10 to 15 fathoms being found within a mile of the coast, and patches of from 5 to 10 fathoms, rocky bottom, 3 miles off shore to the southward.

Fogs.-Low fog banks in the morning are of frequent occurrence, the peaks. showing plainly above them.

San Benito islands.-The easternmost of the San Benito islands lies about 15 miles to the westward of the northern part of Cerros island; the group is about 4 miles in extent east and west, and $1 \frac{3}{4}$ miles north and south. 
The westernmost island is the largest and is nearly rectangular in shape; it is rather flat-topped, with a mound in the center 661 feet high. There is an anchorage on its south side in 10 fathoms, sand bottom, a little to the westward of the southeastern point. A landing place may be found behind some rocks that lie just to the northward of the point.

All three of these islands are barren and surrounded by outlying rocks and kelp. There are boat passages between them.

Pinnacle rocks lie about a mile west of the SW . point of the largest of the San Benito islands. They are about 80 feet apart NE. and SIV., the southern one about 30 feet and the northern one about 10 feet in length on top and from 2 to 4 feet wide. At 100 feet east of the rocks bottom was found at 12 fathoms, but at no other place at the same distance from them was bottom found at 20 fathoms.

Coast.-From San Eugenio point the coast trends southeastward to Breaker point, and consists of rocky bluffs, with projecting points and outlying rocks surrounded by kelp. Sharp, bare hills rise close to the coast, the most conspicuous of which is $1 \frac{1}{2}$ miles northwestward of Breaker point, and is over 600 feet high.

Breaker point is a steep, rocky headland, with numerous detached rocks lying to the southward of it, over which the sea breaks heavily. South of Breaker point the coast recedes about a mile to the eastward. The land is lower, but rugged and barren, as far as Kelp point, which forms the northern limit of port San Bartolomé, and is about 30 feet high, of pudding-stone conglomerate, on a bed of sandstone, with many outlying rocks surrounded by kelp.

Port San Bartolomé is the best harbor on the west coast between San Diego and Magdalena bay. It is nearly circular in general form, and is about $2 \frac{1}{2}$ miles in diameter. The entrance, which lies between Kelp point and cape Tortolo, is a mile in width between the rocks that make off from either side, and is free from hidden dangers.

From cape Tortolo, which is a rocky point about 20 feet high, rising rapidly to an elevation of 417 feet, a reef makes off in a northwesterly direction nearly a mile, its outer end being marked by a rock which is 2 feet above high water.

Between the rock just mentioned and the cape there are three conspicuous rocks of large size, the outer one, Sulphur rock, being 30 feet high; the middle one, called Coffin rock, 40 feet high, and the one nearest the cape, 60 feet high. There are numerous smaller rocks awash and above water, the whole forming a natural breakwater, against which the sea breaks heavily.

The northern and eastern shores of the bay are low shingle and gravel beaches, with generally sandy and low land behind them, which gradually rises to a higher, broken country, with but few traces of vegetation. The western shore consists of high bluffs. 
Anchorage.-Vessels may anchor anywhere in the bay after passing the point of the reef which makes off from cape Tortolo. The soundings are regular and the bottom sand. In the outer bay they will be somewhat exposed to the long regular swell from the ocean.

The best anchorage is to the eastward of the reef that makes off from cape Tortolo, where perfectly smooth water will be found, with protection from every wind. The bay abounds in fish, turtle, and sea fowl; but no indications of fresh water were seen.

Directions. - In making for the port when off the coast, bring a conspicuous jagged peak, 690 feet high, to bear N. $17^{\circ}$ E. (N. $6^{\circ}$ E. mag.) and steer for it until the entrance is plainly visible, after which the eye, assisted by the lead, will be the only guide needed.

This port was formerly much frequented by whalers for the purpose of refitting their ships.

Thurloe head is a bold, rocky point, with a reef extending a short distance off from it to the southward. It lies about $2 \frac{1}{2}$ miles in a southeasterly direction from cape 'Tortolo, the coast between them being a long, irregular cliff, high, rocky, and steep, with high hills just back of it.

Anchorage.-From Thurloe head the coast recedes about a mile to the northward and eastward, forming a small open bay, where vessels may anchor in 6 to 7 fathoms water and find protection from the prevailing coast wind. The land at the bottom of the bay is low, with a shingle beach.

From this anchorage to Morro Hermoso, which is a bare, rocky cliff rising abruptly to a hill of 900 feet in height, the coast consists of steep bluffs from 50 to 100 feet high, with a range of high hills immediately back.

San Cristobal bay.-Between Morro Hermoso and San Pablo point the coast recedes several miles, forming the open bay of San Cristobal, whose shores consist principally of bluffs and sand cliffs from 50 to 100 feet high, the coast range rising to a height of several hundred feet at a short distance inland.

Rocks.-There are a few large outlying rocks near the shore in the northern part of the bay, and a strip of shingle and sand beach 4 miles in extent makes a break in the line of sand cliffs at the place where the indentation in the coast line is deepest. There is a deep arroyo 3 miles north of San Pablo point.

San Pablo point is a dark, slate-colored bluff, with a prominent hill, 760 feet high, rising immediately from it. 'A reef extends off from the point to the southward for about $\frac{1}{2}$ mile, outside of which the water deepens rapidly, no bottom being found at 50 fathoms less than $1 \frac{1}{2}$ miles from the land.

Table lands.- In the vicinity of San Pablo point, a few miles in the interior, are extensive table lands from 1,000 to 2,000 feet high; back of these is a remarkable range of peaks from 2,000 to 3,000 feet high and of variegated colors, which is probably the Sierra Pintada of Sebastian Viscaino ; it corre- 
sponds well with his description, being "of bare and naked rocks of varied and beautiful formation, where great mines of gold and silver are supposed to be."

San Pablo bay is an open bay, about $1 \frac{1}{2}$ miles deep, formed by an indentation in the coast between San Pablo and San Roque points. It is apparently free from all dangers and affords good anchorage in from 10 to 15 fathoms of water at about $\frac{3}{4}$ mile from the shore. At the bottom of this bay there is a sand beach about $\frac{3}{4}$ mile in extent, with steèp bluffs on either side of it.

Coast.-San Roque point is a light-colored bluff from 30 to 50 feet high, with a hill rising just back of it to a height of 518 feet. The water is deep close up to the point, 16 fathoms being found within 100 yards of it. From this point to Asuncion point it is $7 \frac{3}{4}$ miles; the coast between them recedes somewhat, forming the open bay of San Roque, the shore of which is generally bluff, with occasional stretches of shingle and rocky beach fronting the bluff. Back from the coast the country is hilly, with table lands a few miles in the interior.

San Roque island lies $2 \frac{1}{4}$ miles S. $58^{\circ}$ E. (S. $69^{\circ}$ E. mag.) from San Roque point and about $1 \frac{3}{4}$ miles from the bottom of the bay of the same name. It is a rugged rock a mile long east and west, less than $\frac{1}{2}$ mile wide at its widest part, and about 50 feet high.

A reef, over which the sea breaks, extends $\frac{1}{4}$ mile off from the eastern end of the island, and $\frac{1}{2}$ mile eastward from the point of the reef is a patch of rocks with $8 \frac{1}{2}$ fathoms water between it and the reef. Half way between the patch of rocks and the shore of the mainland is a 3 -fathom shoal.

Heavy breakers extend off nearly a mile from the main land north of the island, indicating shoal and rocky ground.

The passage between the island and the mainland is not recommended except for boats or very small vessels.

Asuncion point is a low, sharp, bluff point with a cone-shaped mound about 75 feet high at its outer extremity, and moderately high hills a short distance inland. A reef extends off from the point and on either side of it are several large detached rocks, against which the sea breaks heavily.

Asuncion island lies $\frac{3}{4}$ mile to the southward of Asuncion point; it is $\frac{3}{4}$ mile long and less than $\frac{1}{4}$ mile wide, of sandstone formation, and entirely barren; toward its southern end some hills reach an altitude of 165 feet. The whole island is surrounded by detached rocks and kelp; and from its northern end a reef of rocks, many of them above water and two of large size, extends off 600 yards to the northward and $\frac{1}{2}$ mile to the westward; the sea breaks over it continually. About midway between the point and the island is a solitary rock which is awash at low water. Shoal water extends all the way from the point to the island.

$11562-2$ 
Asuncion bay.-From Asuncion point the coast turns abruptly to the northward for about a mile and then sweeps around to the southeastward to San Hipolito point, forming in its western part Asuncion bay, which is about 2 miles deep and affords good anchorage in moderate weather under the lee of Asuncion point, close to the shore, in from 5 to 7 fathoms water: off shore the soundings deepen rapidly to 30 fathoms and over.

The coast hetween $\Lambda$ suncion and San Hipolito point is low and sandy, with an occasional bluff. Hill and table lands of moderate elevation rise at a short distance inland.

Phenomena.-On June 5 and again on September 6, 1892, the steamer Newbern, when about 15 miles of San Hipolito point, and in latitude $26^{\circ}$ $47^{\prime} \mathrm{N}$.; Iongitude $114^{\circ} 15^{\prime} \mathrm{W}$., passed through waters covered with crude petroleum and floating asphalt for a distance of 3 or 4 miles. The strong odor of mineral oil was very perceptible.

San Hipolito point is low and of black rock, with barren sand hills 50 to 100 feet high rising a short distance from it. A shelving, rocky reef, over which the sea breaks, extends southward from it nearly $\frac{1}{2}$ mile. A remarkable table-shaped mountain, 1,227 feet high, lies $5 \frac{1}{2}$ miles northward of the point.

From San Hipolito point the coast turns abruptly to the northward for $1 \frac{1}{2}$ miles, thence to the eastward for about 3 miles, and then sweeps around to the southeastward toward Abreojos point.

San Hipolito bay.-The open bay formed by the indentation in the coast line east of San Hipolito point is called San Hipolito bay, where good anchorage may be found under the lee of the point, in from 5 to 6 fathoms, sandy bottom, at $\frac{1}{2}$ mile from the shore.

Coast.-The coast as far as Abreojos point is low and sandy, the land back of it rising gradually to hills and table lands from 600 to 1,000 feet high ; in the distance may be seen high and broken mountains.

The soundings are regular and the water bold along this portion of the coast until within about 11 miles of Abreojos point, when the soundings become irregular and the water shoaler. About 8 miles northwestward from the point a shoal about 2 miles in extent, over which the sea breaks heavily, makes off over a mile from the shore; it is probably the mouth of a lagoon which lies parallel to the coast, ending near Abreojos point, which, at very high tides, communicates with the sea. Two miles farther up the coast is a smaller shoal making off about $\frac{1}{2}$ mile.

Abreojos point is low and sandy, being composed of a bed of pudding- . stone conglomerate which rises about 5 feet above high-water mark, and is covered with a layer of sand 10 to 15 feet in depth, in which are growing some stunted bushes. A reef extends a short distance south from the point, and there are numerous detached rocks on the eastern side close to the shore. 
A barren hill 312 feet high, in front of and separated by a conspicuous range of table land 600 feet high, lies 3 miles N. $6^{\circ}$ E. (N. $5^{\circ} \mathrm{W}$. mag.) from the point, and is a good landmark for it when off the coast.

Whale rock, which is about $\frac{1}{4}$ inile long by 200 yards in width and 10 feet above high water, lies 4 miles S. $85^{\circ}$ W. (S. $74^{\circ}$ W. mag.) from Abreojos point. A reef connected with it, over which the sea breaks heavily, makes off for over $\frac{1}{4}$ imile in a southeasterly direction.

Reef -A dangerous reef lies nearly a mile to the southwestward of the rock, with a passage between them, in which was found from 5 to $8 \frac{3}{4}$ fathoms water. The reef is nearly $\frac{3}{4}$ mile in extent north and south, and $\frac{1}{3}$ mile east and west; many of the rocks are awash at low water and the sea breaks heavily over them.

There is a passage between Whale rock and the mainland $1 \frac{1}{2}$ miles wide, through which $4 \frac{1}{2}$ fathoms may be carried.

The soundings to the southward and to the westward of the rock and reef increase quickly to 10 and 20 fathoms.

Wright shoals lie about $1 \frac{3}{4}$ miles from Abreojos point between the bearings of South (S. $11^{\circ} \mathrm{E}$. mag.) and S. $40^{\circ}$ E. (S. $51^{\circ}$ E. mag.) from the point. They consist of numerous shoals with from 2 to 3 fathonss water over them and apparently clear water between.

Abreojos point anchorage.-A good anchorage may be found to the eastward of Abreojos point in about 6 fathoms. In making for the anchorage vessels are advised to give the reef to the southward of the point a wide berth. Abreojos point and the land in the vicinity is the farorite resort of the prong-horned antelope, large droves of which were seen, as well as the coyote, or cajote, a species of wolf; both are very cunning and shy. At the foot of a barren hill on the SE. side is a pond which contains brackish water not fit for drinking, but from the large numbers of animals seen there is undoubtedly fresh water to be found at no great distance.

Knepper shoal, with $2 \frac{1}{4}$ fathoms water over it, lies $2 \frac{1}{2}$ miles $\mathrm{N} .75^{\circ} \mathrm{E}$. (N. $64^{\circ}$ E. mag.) of Abreojos point, and nearly a mile off shore.

Ballenas bay.-From Abreojos point the coast trends to the northward and eastward, forming, with the west end of a low sand island, that bears almost east from the point and its surrounding shoals which uncover at low water, a large open bay from 5 to 6 miles deep, known as Ballenas bay. The soundings in this bay are quite regular, with moderately deep water close to the shore, except off the entrances to the lagoons, which will be described hereafter. With strong winds a heavy swell rolls into the bay, causing a high surf on the beach.

The shores of the bay are extremely low and sandy, except on the western side, where two rocky points project, connected by low bluffs, behind which the land gradually rises to the hill before mentioned. 
Lagoon.-About 9 miles northeastward of Abreojos point is the entrance of a large lagoon that extends about 8 miles in a northerly direction. A shoal over which the sea breaks extends about $\frac{3}{4}$ mile off its mouth.

San Ignacio lagoon.-The coast, for 103 miles to the eastward of the entrance of the lagoon just described, is low and sandy, terminating in San Ignacio point and forms the western side of the entrance to San Ignacio lagoon. Only vessels of small size can enter. Extensive shoals which partly uncover at low tide make off from this lagoon. The channel, in which will be found from 9 to 13 feet at low tide, is narrow and tortuous; it is clearly marked by the line of breakers on either side, which are the best marks for entering. Vessels drawing 12 feet may cross the bar at ordinary high tide. As soon as the bar is crossed the water deepens rapidly. At full and change of the moon the strong tide causes a heavy swell on the bar. At this particular place the land and sea breezes are strong and regular; were it not for this the passage. would not be practicable for sailing vessels. Not far from the head of the lagoon is the village of San Ignacio, which numbers about 20 families.

Products.-Near the village are extensive tracts of cultivated land on which are raised grain, all sorts of vegetables, sugar cane, dates, figs, olives, grapes, and many other fruits.

A never-failing supply of running water relieves the village from all danger of drought.

Caution.-The several passages into the lagoon are narrow and shallow. The lead is a good guide along this part of the coast; the land being low, its proximity is not easily distinguished, especially at night.

Anchorage.-In moderate weather, good anchorage will be found off the entrance to San Ignacio lagoon, in from 4 to 5 fathoms, sandy bottom, San Ignacio point bearing N. $57^{\circ}$ E. (N. $46^{\circ}$ E. mag.), distant 3 miles.

Coast.-From the shoals off the entrance to San Ignacio lagoon the coast trends to the southward and eastward 40 miles, to San Domingo point. Throughout the entire distance it is low and sandy, and for 32 miles from San Ignacio lagoon, a lagoon lies parallel to the shore, having a strip of sand beach about a mile wide (through which there are several passages) between it and the sea.

San Domingo point is a remarkable perpendicular rocky cliff of dark color, 175 feet high, the cliff extending for several miles above and below the point. A short reef extends off the point in a southwesterly direction ; $\frac{1}{2}$ mile distance from the edge of the reef 15 fathoms water were found, sandy bottom.

Anchorage.-Anchorage may be found to the eastward of the point, under its lee, in from 5 to 6 fathoms, $\frac{1}{2}$ mile from the shore, where a vessel will find some protection from the prevailing wind. 
The surf breaks heavily on the rocks at the foot of the cliff, and unless the weather is quite moderate it will be found difficult and dangerous to effect a landing.

Coast.-From San Domingo point to San Juanico point the coast consists generally of sand hills from 100 to 200 feet high with high tabletable lands and mountains farther inland. At $3 \frac{3}{4}$ miles eastward of San Domingo point there is a break in the cliffs, through which is the entrance to a small lagoon. A shoal extends a short distance off this entrance, over which only small boats can pass.

Pequeña bay.-Twelve miles from San Domingo point there is a rocky point with bluffs of a volcanic nature 15 to 30 feet high, and a hill at the point 85 feet high. For about $\frac{1}{2}$ mile off this point the water is shoal with rocky bottom, over which the sea breaks. Outside the shoal the water deepens quickly, 12 fathoms being found within 400 yards and 22 fathoms at $\frac{1}{2}$ mile from its outer edge.

After passing this point the land falls away to the north ward for $1 \frac{1}{2}$ miles, whence it turns abruptly to the eastward for about 3 miles and then gradually sweeps around to San Juanico point, forming Pequeña bay, in which vessels may find shelter from the prevailing coast wind by anchoring to the northeastward of the point, a mile from the shore, in from 5 to 6 fathoms.

San Juanico point is a sand bluff about 50 feet high, resting on a bed of conglomerate. About $2 \frac{1}{2}$ miles northwestward of the point a shoal makes off from the land from $\frac{1}{2}$ to $\frac{3}{4}$ mile, its outer edge lying nearly parallel with the coast until after passing the point, when it gradually trends toward the shore, terminating about $1 \frac{1}{4}$ miles eastward of the point.

San Juanico lagoon.-A About $\frac{1}{2}$ mile to the eastward of San Juanico point is the entrance to the lagoon of the same name. The entrance is narrow and only about 3 feet of water will be found on the bar at low tide. The lagoon extends about 6 miles in a northerly direction and is widest in its northern part. It has an average depth of about 2 fathoms, but is much cut up in its southern part by shoals and sand bars. Small coasters drawing 6 or 7 feet enter it, crossing the bar at the highest spring tides. Considerable orchilla is gathered near the shores of this lagoon.

Anchorage.- Vessels may anchor to the sontheastward of San Juanico point in 5 to 6 fathoms, about a mile from the shore, and find some protection from the coast wind. Not far from the shore, on a barren hillside, is a spring the waters of which are slightly sulphurous.

Sierra de la Giganta. - When off the coast the famous peaks of Sierra de la Giganta, over 5,000 feet high, are distinctly visible, overtopping the intervening ranges of mountains.

From San Juanico point the coast trends to the eastward for a short distance and then curves around to the southward; 10 miles below the point 
the hills and table lands cease; thence to cape San Lazaro the colst is low and sandy, with high land many miles in the interior.

Boca de la Purissima, 11 miles S. $43^{\circ}$ E. (S. 5:3 E. mag.) from San Juanico point, is open to the sea only during the rainy season. The valley through which the stream runs is narrow but fertile. The old village of Purissima has about 250 inhabitants and lies about 10 miles inland.

Only a small portion of the land near the village is cultivated; cotton, sugar cane, wheat, vines, figs, oranges, peas, etc., are raised almost without labor. The lomboi (a small tree of soft, brittle fiber), from the salp of which an indelible ink is made, found nearly the whole lergth of the peninsula, flourishes luxuriantly here.

One of the principal occupations of the people is the manufacture of mescal, or pulque. It is a strong alcoholic liquor made from the sap of the maguey, a species of aloe.

Boca de Comandu. - Seven miles to the south ward of Boca de la Purissima is the Boca de Comandu. Like the former, it is open to the sea during the rainy season only. The ancient mission of Comandu is about 25 miles distant, in a fertile valley, near the headwaters of the river.

Boca de las Animas is the northernmost of three entrances to a series of lagoons that, commencing about 5 miles south of Broa de Comandu, extend the entire distance to Magdalena bay and are connected with it. These lagoons lie nearly parallel to the coast and are connected with one another; they are separated from the sea by a narrow strip of sand and are used by the small, light-draft coasting vessels.

The Boca de las Animas is about $\frac{3}{4}$ mile wide and is encircled by a shoal that extends $\frac{1}{2}$ mile off shore, over which the sea breaks. The best channel is on the sonthern side, near the beach, where 3 feet of water will be found at low tide. As soon as the bar is crossed the water deepens to 3 and 5 fathoms. The lagoon in this vicinity is filled with shoals and islands, and branches off in all directions; its shores are covered with a thick growth of mangroves.

Boca de San Domingo is the middle one of the three entrances before mentioned and is $9 \frac{3}{4}$ miles south of Boca de las Animas, the coast between them being a low sand beach, with occasional low hills and a few bushes. It is $\frac{3}{4}$ mile wide with a shual extending a mile off the entrance. The best channel is through the middle of the entrance, the breakers on either side plainly marking it; a high mountain 50 miles distant makes an excellent leading mark.

The least depth on the bar at low water is $2 \frac{1}{2}$ feet; tides rise 5 feet.

Boca de Soledad is the southernmost and deepest of the three entrances into the lagoons, and $13 \frac{3}{4}$ miles to the south ward of Boca de San Domingo. It is not over $\frac{1}{2}$ mile wide, and is marked on either side by a ridge of sand hills 50 to 100 feet high. From its southern side an extensive shoal, over 
which the sea breaks, extends off to the northward and westward $1 \frac{1}{2}$ miles. From the northern side the breakers do not extend far from the beach.

Directions.- To enter, approach from the northward, keeping close to the line of breakers making off from the northern side of the entrance; following this line the shoalest part of the bar will be crossed, on a southerly course, in 9 feet water, at low tide, and when midway between the two points of the entrance, the course at this time being easterly, there will be from 5 to 8 fathoms water. The tide runs at a rate of from 4 to 5 knots between the points of the entrance, and rises about 5 feet.

Between Boca de San Domingo and Boca de Soledad the lagoon has numerous inlets to the eastward.

General remarks.-The description that has been given of the entrances to the lagoons refers to them at the time of the Narragansett's visit in 1874. There is good reason to believe that the shoals arid bars at the entrances are subject to occasional changes, necessitating a previous examination before attempting to enter. At high water and in moderate weather the channels are plainly marked by the smooth water between the lines of breakers. At low water and in heavy weather the breakers will extend farther out and sometimes across the entrance.

Wells. - On the plains fronted by the lagoons there are many wells furnishing a permanent supply of good water.

Cape San Lazaro.- The coast south of Boca de Soledad retains the same general character as that to the north ward, being low and sandy, until reaching cape San Lazaro, which is a high, remarkable looking headland of volcanic origin, which can be seen for many miles, and when first made out appears like an island. About this headland are bold rocky cliffs, with high rugged mountains immediately back, the highest being 1,300 feet high. There are numerous outlying rocks along the shore, extending off $\frac{1}{4}$ mile on the northwestern and southeastern points of the headland.

From the cape proper the coast trends about SE. $3 \frac{1}{2}$ miles to a low rocky point, from which it turns abruptly north for 2 miles to the mouth of a small lagoon.

Santa Maria bay.-Between cape San Lazaro and cape Corso the coast recedes considerably, forming Santa Maria bay, which is $4 \frac{1}{2}$ miles deep from a line drawn between the two capes. The land around the bay is merely a sand beach interspersed with low sand hills and a few bushes, separated from the mainland by the lagoons connecting with Magdalena bay. The soundings in this bay are very regular, increasing gradually from 3 fathoms near the shore to 20 fathoms at its outer limit.

Good anchorage will be found in from 5 to 8 fathoms water, sandy bottom, near the western shore of the bay, at from $\frac{1}{2}$ to $\frac{3}{4}$ mile from the beach, where a ressel will be well protected from the prevailing winds. 
Cape Corso is a bold, rocky point, fronted by white sand bluffs from 70 to 80 feet high, upon which, in marked contrast, dark-colored hills rise abruptly to a height of 600 feet and upwards.

From cape Corso to Entradla point the coast is a succession of rocky points and intervening sand beaches, with numerous detached rocks close to the shore. The land rises abruptly to a height of from 500 to 1,000 feet and over, mount Isabel, the highest peak, being 1,592 feet high.

Entrada point, at the northwestern side of the entrance to Magdalena bay, is a dome-shaped hill about 200 feet high, connected with the mainland by a narrow strip of sand and rock, which is but a few feet above high-water mark. There are several outlying rocks from 10 to 20 feet high quite near it, and a reef makes off to the SE. about 300 yards, over which the sea generally breaks.

Cape Redondo is the westernmost point of Santa Margarita island, and is a round, rocky headland nearly 100 feet high, the land rising rapidly back of it to a height of over 500 feet.

Reef.-A reef extends off to the westward from the cape a distance of 600 yards, its outer limit marked by a rock awash. The sea breaks over this reef in all weathers, although Lieutenant Tanner, U. S. N., observed an interval of two hours, including the last of the flood and the first of the ebb, in which there was no break on the outer rock; it was perfectly calm and the sea smooth at the time. Lieutenant Tanner also says: "I observed at the beginning of the flood a heavy overfall at least 400 yards off from the extremity of the reef, where Lieutenant Taussig, U.S.N., found from 7 to 9 fathoms of water."

This may account for the rock reported near the middle of the channel.

Magdalena bay, a most spacious and safe harbor, is about 15 miles long, NW. and SE., and 12 miles wide. At its northwestern limit it is connected with a series of lagoons (already mentioned), which extend in a northerly direction upward of 60 miles. At the junction of these lagoons with the bay there are several shoals and sand bars, the depth of water in the channels between them varying from 4 to 8 fathoms. Whaling vessels have ascended these lagoons for a distance of 40 miles from the bay.

Numerous small lagoons are scattered along the northern shore of the bay, and shoal water extends off from that shore from one to 2 miles.

At the southeastern limit of this great bay it is connected by a navigable channel with another large bay, called Almejas or Lee bay.

The entrance to Magdalena bay is between Entrada point and cape Redondo, and the channel between the reefs that make off from either point is $2 \frac{1}{2}$ miles wide, with from 10 to 20 fathoms water and no hididen dangers. It has usually been recommended to keep well over toward Entrada point in entering, but there is no reason why a steamer should do so, as the chan- 
nel is clear to within $\frac{1}{2}$ mile of cape Redondo. With a sailing vessel it is best to keep well up toward Entrada point, as both the prevailing wind and the current tend to set her down toward cape Redondo.

Anchorage.- To reach the best anchorage, at all seasons, follow the land to the northwestward from Entrada point, keeping at a distance of $\frac{3}{4}$ mile from it, to Man-of-War cove, and anchor in from 8 to 10 fathoms water, abreast of some houses that are near the beach, $7 \frac{1}{2}$ miles from Entrada point. The best course in to an anchorage is with the outer end of the wharf in line with the south end of a large house (two stories, and the highest in the settlement) $\mathrm{N} .74^{\circ} \mathrm{W} .\left(\mathrm{N} .84^{\circ} \mathrm{W}\right.$. mag.) anchoring in from 7 to 9 fathoms.

Landing.-There is a wharf with landing steps at Man-of-War cove, but in smooth weather the beach is usually preferred, as it is sufficiently steep to permit of landing dry-shod from ship's boats.

Remarks.-The following remarks by Capt. W. H. Parker, P. M. S. S. Co., will be found useful when making for the anchorage in Man-ofWar cove in the night:

"Having rounded point Entrada, $\frac{1}{2}$ mile distant, haul up along the land to the westward. From Entrada point to mount Isabel the land is only tolerably high. Mount Isabel is the first high land after entering, and when that is abeam the shoal or sand spit running off from the low point (the only danger) 3 miles inside of Entrada point is abaft the beam, and you can haul up with safety for Cove point. Thence to Cove point the land is high, gradually sloping toward the point.

The land recedes a little from Entrada point to the sand spit.

You can not fail to make Cove point distinct from the land back of it. Run close to it, and follow to the anchorage, which is directly off the houses. Anchor in 8 or 9 fathoms water, $\frac{1}{3}$ mile from the beach.

The land back of the houses is high, with low land to the right."

Settlement.-In 1874 there were about ten houses in the settlement, one of which was the customhouse.

The United States is represented by a consular agent.

Trail to La Paz.-A rough trail through a barren and almost level country leads to $\mathrm{La} \mathrm{Paz}$, distance about 115 miles.

Anchorage.-In the winter months, with southerly winds, good anchorage will be found in the southern part of the bay; the chart is sufficient guide for picking out an anchorage. The lead should, of course, be carefully attended.

Tides.-The tides in the bay are regular and cause strong currents through the entrance (from 1 to 2 knots per hour). Springs rise $5 \frac{1}{2}$ feet; neaps, 3.9 feet.

Water.-In the summer season the only regular supply of fresh water is obtained about 40 miles from the bay, near one of the northern lagoons. 
Small vessels make regular trips for the express purpose of bringing it to the settlement. There are several places marked on the charts of the bay as watering places. 'This is accounted for by the fact that water of inferior quality was obtained by whalemen by sinking a cask in the sand on the beach.

The water obtained in this way was of a milky-white appoarance, and had to settle a few days before it became clear and drinkable.

There is said to be a spring of excellent water near the southern end of Santa Margarita island.

Supplies.—Fish, oysters, clams, mussels, and abalones are abundant in the bay and lagoons, and there is plenty of game on the northern shore. Plenty of wood may be obtained, the shores of the lagoons being covered with a thick growth of mangrove bushes.

Santa Margarita island is a high barren island of volcanic origin, $21 \frac{3}{4}$ miles long and of varying width, being $4 \frac{1}{4}$ miles wide at its widest part. It presents a bold rocky face its entire length, except a small space in the center, where the land recedes somewhat, forming on the south side an open bay called Pequena bay; the land hereabout is low and sandy, and the island at this place is only $1 \frac{3}{4}$ miles wide. A short distance to the $\mathrm{SW}$. of Pequeña bay there are two remarkable peaks 1,755 feet high, known as the Sisters. At about the same distance to the NW. of the bay is a prominent white bluff point 200 feet high, off which there is a reef and some outlying rocks above water.

Cape Tosco is the extreme southeastern point of Santa Margarita island, and is a sharp, boll, rocky point, with a reef extending off to the southeastward about 600 yards, over which the sea breaks with great violence.

Anchorage.-A tolerably good anchorage may be found to the eastward of the cape, under its lee, in from 7 to 9 fathoms water.

Cresciente island is a low sand island in something like crescent form, about 10 miles long in a nearly east and west direction; Santa Maria point, its southwestern extremity, lies $3 \frac{3}{4}$ miles from cape Tosco.

Rehusa channel, lying between Santa Margarita and Cresciente islands, is too narrow and intricate for anything except boat navigation. A shoal extends $1 \frac{1}{2}$ miles off Santa Maria point to the southeastward, and between it and cape Tosco are several shoal spots over which the sea breaks.

'The tides run strongly through this channel, causing many tide rips and overfalls.

Almejas or Lee bay is in reality a continuation of Magdalena bay, being connected with it by a navigable channel called Marcy channel, which has an average width of about a mile between the shoals that line the shores on either side, and with a depth varying from 6 to 17 fathoms. The bay is about 12 miles long, of the same general trend as Magdalena bay and over 7 miles wide. On its northern and eastern sides are extensive shoals. 
Shoal.-A sounding of 5 fathoms has been obtained in Marcy channel with Lengua point beacon bearing S. $46^{\circ}$ E. (S. $56^{\circ}$ E. mag.), distant $2 \frac{3}{10}$ miles.

El Conejo point is a low point on the mainland opposite the eastern end of Cresciente island. It is backed to the north by a dome-shaped mound about 50 feet high and separated from it by a narrow ąrm of a lagoon making to the eastward.

The general trend of the coast from El Conejo point to Lobos point is about SE. by E., and the land is generally low, sandy, and barren. A bout half way between the two points is a low, rocky point called Del Marquis point. A reef of rocks extends a short distance off from it, and on either side near the coast are low sand bluffs.

Las Mesas.-At a distance of 5 to 10 miles inland are some irolated table-shaped hills 600 to 800 feet high, known as Las Mesas. The land in the interior generally rises gradually toward the gulf coast, with conspicuous table lands here and there. From del Marquis point to the bottom of La Paz bay, about 25 miles in a northeasterly direction, the land is low and flat for nearly the entire distance, with a scanty growth of stunted trees, bushes, and cactuses.

Vessels may anchor anywhere along this part of the coast in fine weather in from 8 to 10 fathoms, a mile or two from the beach. The soundings are regular and there are no known hidden dangers. Breakers extend some distance off shore.

Caution.-In sailing along this part of the coast the learl slould be frequently used, as the land is low and not easily discerned, especially at night or in thick weather, and the lead hecouies the best means of ascertaining its proximity.

When approaching Lobos point the high mountains back of La Paz and the sharp peaks of the Sierra de la Victoria are plainly visible, mount Aguja, the northernmost and most conspicuous of the latter range, being 5,924 feet high.

Five miles to the northward of Lobos point is the Arroyo de las Palmitas, with a grove of palm trees on either bank at its mouth and a beautiful valley extending inland.

Todos Santos river is a never-failing running stream of water, which flows through the fertile valley of the same name, reaching the sea about $1 \frac{1}{2}$ miles to the northward of Lobos point.

The point on the southern side of its mouth is known as La Pozal point, and is the northern end of a table land extending from the vicinity of Lohos point. It is a perpendicular bluff about 50 feet high, with numerous outlying rocks.

Todos Santos.-The village is situated on the bank of the river of the same name, 2 miles from its mouth. A road leads to it from a sand beach 
situated about $\frac{1}{2}$ mile above Lobos point, which is the best landing place in the vicinity. The village is on the site of the ancient mission of Santa Rosa, and is beautifully situated in a fertile valley, where all the arlvantages of a temperate and tropical climate are combined, with few of the disadvantages of either.

Products.-It is surrounded by well-cultivated fields of sugar cane, while in its gardens are found the cereals and vegetables of the north, together with the fruits of the south. The population is about 800 .

This is an excellent place to procure fresh provisions and water.

Anchorage.-In moderate weather a good anchorage may be found in from 7 to 10 fathoms, sandy bottom, $\frac{1}{3}$ mile off shore and about $\frac{1}{2}$ mile to the northward of Lobos point. Anchor immediately after passing the range between Lobos point and the next point to the southward, San Pedro point.

Lobos point is the northwestern point of a.high rocky promontory. It projects at a sharp angle from a sand beach which joins it to the northward, forming a little cove, slightly protected from the ocean swell. The best landing place is at the junction of the sand beach with the rocky point.

The coast for 20 miles south of Lobos point is in general a succession of sand beaches and rocky bluffs, the latter forming slight projections in the coast line; the land immediately back of the coast is hilly, with high and broken mountains in the interior.

San Pedro point is $\frac{3}{4}$ mile to the southward of Lobos point and is the southwestern extremity of the same promontory. Just south of the point is a small bay, formed by a slight indentation in the coast line, called San Pedro bay, where landing is said to be praticable in good weather. Back of the sand beach that encircles the bay is a fertile valley in which the settlement of San Pedro is situated. The southern limit of the bay is marked by a steep, rocky bluff which extends about $1 \frac{1}{2}$ miles to the southeastward, and $3 \frac{1}{4}$ miles from the southern end is a bluff, rocky point on which is a conical-shaped hill 414 feet high.

Pescadores bay.-On either side of the point which forms the southern limit of San Pedro bay is a sand beach; the southern one receding somewhat forms the bay of Pescadores, near the shore of which, $\frac{1}{2}$ mile from the beach, is a small fishing village.

Casparino point is a rocky bluff 75 feet high just south of Pescadores bay. From this point to La Tinaja point is $8 \frac{1}{2}$ miles. Between the points are two arroyas, the northern of which has a small settlement on its banks, with some palm trees. The banks of the southern one are bluffs of a yellow color. 
La Tinaja point is a rocky bluff 75 feet high with a hill rising rather abruptly from it to a height of 596 feet; $3 \frac{3}{4}$ miles from the point is La Tinaja (the pitcher), a conspicuous mountain 2,183 feet high.

Soundings. - The soundings along this part of the coast show a depth of 100 fathoms and upwards within 2 or 3 miles of the coast.

Cerro de la Playa is a rocky bluff 75 feet high, back of which rises abruptly a conical bill 1,114 feet high. About $2 \frac{1}{2}$ miles south of this point is a rell colored bluff, rocky and 50 feet high, with numerous rocks at its foot; northward of it, close to, is a ranch.

San Cristobal point is a bold rocky bluff from 200 to 300 feet high.

The coast from San Christobal point gradually sweeps around to the eastward to cape Falso, and consists of steep sand beaches, back of which are sand bluffs of a whitish color from 150 to 300 feet high, covered with patches of low shrubs, which appear dark in contrast with the white background. From these bluffs the coast range of hills rises gradually to a moderate height, decreasing somewhat in height toward cape Falso, and rising again suddenly $1 \frac{1}{2}$ miles north of the cape to a double hill 778 feet high, known as the Paps.

Cape Falso is the southernmost point of the peninsula of Lower California, and is a rocky bluff about 50 feet high with many detached outlying rocks near the shore. The coast is bold and may be approached within $\frac{1}{4}$ mile, carrying 5 and 6 fathoms of water. A mile south of the cape 55 fathoms sandy bottom were obtained.

Between cape Falso and cape San Lucas the coast is a succession of sand beaches and bold rocky bluffs, against which the sea breaks heavily, even in the finest weather. Barren hills from 400 to 800 feet high rise immediately back of the beach.

Three-quarters of a mile west of cape San Lucas there is a gap in the hills where a strip of sand beach 200 yards in width extends through from St. Lucas bay to the sea. From this beach to the cape is a wedge-shaped mass of steep rocky hills, the highest of which, Vigia hill, is 527 feet high.

Los Frailes are two high, bold, and, upon certain bearings, grotesquelooking rocks, with a number of smaller outlying rocks near them.

The western one, connected with the just-mentioned wedge-shaped ridge of hills by a narrow strip of sand beach, is 303 feet high, of sugarloaf shape, and has on its eastern side an archway through which the sea rushes with great force.

Cape San Lucas.-The eastern Fraile is 251 feet high, with nearly perpendicular sides, and is the cape San Lucas proper. A large rock lies about 100 feet to the eastward of it, but on account of its inferior height is not visible at any great distance. This fantastically formed headland, when once seen, is not likely to be forgotten. 
Los Frailes are said to be of granite. A deposit of guano gives them a chalky white appearance.

San Lucas bay, lying to the northward and eastward of the wedgeshaped ridge of hills of which cape San Lucas is the extremity, affurds good anchorage and shelter from northwesterly winds, but is exposed to the sea from south around to east, rendering it an exceedingly unsafe anchorage during the summer or wet season, when southeasterly gales are both frequent and heavy.

Anchorage. - The best anchorage is in the northwestern part of the bay in 6 or 7 fathoms of water, $\frac{1}{4}$ mile from the beach. The soundings in the bay are very irregular and to the northward and eastward of the cape show a remarkable depth of water for a short distance across the bay.

Directions.-After passing the Frailes, which may lie approached close to, steer about N. $24^{\circ} \mathrm{W}$. (N. $34^{\circ} \mathrm{W}$. mag.) for Ritchie's, a large white house of two stories, and the first object seen in making the anchorage. Keep the lead going and be ready to let go the anchor at a moment's warning. Anchor in from 6 to 12 fathoms, but be sure to have the lead on the bottom when the anchor is let go, as the bank is very steep.

Landing place.-The best landing place is in the SW. part of the bay, where the sand beach joins the high headland.

The village of San Lucas consists of about a dozen houses, including a customhouse, and 150 inhabitants. It is situated on a level tract of land immediately back of a high ridge of sand mounds and knolls. The chief support of the people is raising eattle, for which the country is well adapter, and there are some extensive ranches in the vicinity. A road runs along the coast from here to San José del Cabo, a distance of 16 miles.

Supplies.-Wood, good beef, and vegetables can be obtained at moderate prices, as well as an abundance of fresh water of fair quality. There is plenty of game in the vicinity.

The California and Mexican line of steamers call here each trip.

\section{OFFSHORE ISLANDS AND SHOALS.}

Cortez shoal lies about 46 miles southwestward of Clemente island. The nature of the bottom is hard, composed of white sand, broken shells, and fine coral at the SE. portion, and sand with broken shells at the NW. The shoalest and most dangerous part is that known as the Bishop rock, lying 5 miles from the SE. tail of the bank, and having but $2 \frac{1}{2}$ fathoms of water upon it. Around this danger the depth increases gradually, and in an extent of $2 \frac{1}{2}$ miles in the general direction of the bank reaches but 15 fathoms.

Upon this bank the current is variable, frequently setting against the strong NW. winds with a velocity of nearly 2 miles per hour, producing 
at all times a heavy swell and even in moderate weather breaking heavily on the rocks. Proximity to the bank at night has been noticed by the increased swell.

This bank lies in the direct route now followed by the Panama and San Franciseo steamers. Bishop rock is the only rock supposed to exist. As it is difficult to find single points below the surface in a seaway it will not be surprising if others are found. A prudent navigator will give this bank a wide berth. Its existence forcibly suggests that there is a possibility that other submarine ridges lie parallel to the coast.

Guadelupe island, lying in lat. $29^{\circ} 10^{\prime} 50^{\prime \prime} \mathrm{N}$., long. $118^{\circ} 18^{\prime} 30^{\prime \prime}$ W. (ohs. spot at North point), is $14 \frac{1}{2}$ miles long in a north and south direction, and from 3 to 5 miles wide. It is of volcanic origin and has a ridge of mountains throughout its length, the highest of which, near the northern end, is 4,523 feet high. The island can be seen in clear weather at a distance of abont 60 miles and will appear, when bearing either east or west, lower at its southern extremity than at its northern. The shores are generally bold, rocky bluffs, with detached rocks close to.

Off the south end of the island are two rocky islets, one of which is $\frac{1}{2}$ mile and the other, which is 560 feet high, $1 \frac{1}{2}$ miles from it.

The southern part of the island is very barren, but in the northern part there are several fertile valleys and there is some vegetation on the mountains.

Wood and water may be obtained from a small cove on the NE. side of the island.

Anchorage.-There is a small cove on the SE. side of the island, formed by a few outlying islets, where vessels may anchor in 7 fathoms water and find shelter from all winds except those from SE. to ENE., which seldom blow here. There are no dangers to navigation at a distance of $\frac{1}{4}$ mile from the shores of the island. Sailing vessels bound from San Francisco to the gulf of California generally sight it, passing to the westward on account of the stronger $\mathrm{NW}$. winds.

The longitude given for the north point of this island may be slightly in error, as no late determination has been made.

Alijos rocks are a dangerous group lying in the track of sailing vessels bound down the coast of California, in latitude $24^{\circ} 58^{\prime} 06^{\prime \prime} \mathrm{N}$. and longitude $115^{\circ} 44^{\prime} 47^{\prime \prime} \mathrm{W}$. They extend about $\frac{1}{2}$ mile north and south and not over 200 yards east and west ; the southernmost and highest of the four principal rocks is 112 feet high and the northernmost is 72 feet high. Besides the four principal rocks there are numerous smaller ones, the whole appearing, when seen from a distance, like a ship under sail.

Reported islands and shoals.-Numerous shoals and islands have been reported to exist off the coast of Lower California as far as $140^{\circ}$ west. Among them are New island, Maria Laxara island, Gaspar rock, Paxaros, 
Passion, Cooper, and Henderson islands, with some others. Careful search has been made for them by the United States ships Portsmouth and Narragansett in the years 1873 to 1875 without finding them or detecting any indications of land near the positions assigned to them.

Similar search has been made by vessels of other governments with the same result. 


\section{CH A P'T E R I I.}

GULF OF CALIFORNFA - EAST COAST OF THE PENINSULA OF LOWER CALIFORNIA.

Remarks.-The east coast of the peninsula of Lower California, bordering on the gulf, from cape San Lucas to the mouth of the Colorado river, is, with few exceptions, high and precipitous, the mountains rising abruptly back of it.

Off the coast there are numerous islands, with navigable channels between them and the mainland.

The depth of water near the east or gulf coast of the peninsula is generally much greater than it is near the western or Pacific coast, but there are many places where vessels may anchor and find protection from the prevailing winds.

The coast and islands near it are generally barren, but there are some exceptions, among which are San Josef island, and the vicinity of Loreto and Mulege, on the gulf coast, and the vicinity of San Lucas bay and the valley of San José del Cabo, at the southern extremity of the peninsula.

Winds.-The prevailing winds in the gulf of California, from November to May, are from the NW.; during the remainder of the year SE. winds prevail. In the upper portion of the gulf moderate $\mathrm{NW}$. gales are frequently experienced during the months of December, January, and February. They generally last from two to three days. During the rainy season, or from May to November, southeasterly gales may be expected at any time in the lower part of the gulf.

Occasionally (usually with an interval of several years between them) a local hurricane or cyclone, known as El Cordonazo, blows with great violence; these occur at about the end of the rainy season and always blow from SE. to SW. They are of short duration but temendous force, and are accompanied by much lightning.

Weather.-During the greater part of the year the weather along the coast is fair and pleasant, the heat of the day during the summer months being made tolerable by the succeeding cool nights. The scarcity of rain is compensated for, in some measure, by frequent heavy dews. During the winter months the $\mathrm{NW}$. winds passing over the snow-covered peaks of the Calamahue mountains cause a quite low temperature in the northern part of the gulf.

Although the rainy season is said to be from May to November, but little rain falls during that period on the peninsula of Lower California, $11562-3$ 
and the land is for the most part dry and hot. Unlike the eastern or Mexican coast of the gulf in this respect, the rains, except in the southern part of the peninsula, occur mostly in the winter months. Summer rains are almost unknown north of Carmen island.

The following, taken from the work of M. Duflot de Mofras, attaché of the French legation at Mexico, and published in 1844, may prove valuable to the navigator:

"The year is divided into the dry and rainy seasons, the changes of which occur at variable periods. During the dry season the weather is always fine, the winds blowing regularly during the day from $\mathrm{NW}$. to west, following the direction of the coast; they are replaced at night by a light breeze off the land or by calms.

The rainy season, which commences in June, is at first indicated by calms and light showers of rain. As the season advances the showers become heavier, and, instead of occurring only at night, they commence in the afternoon and terminate in very violent tempests, accompanied by thunder and lightning and violent winds from all points of the compass. This weather continues until the end of September, and it often happens that the season terminates with a violent hurricane, that usuallyoccurs between the 1st and 5th of October.

These hurricanes, which always blow from SE. to SW., are of short duration, but are of such violence and raise such a tremendous sea that nothing can withstand them. They are known in the country as Los Cordonazos de San Francisco. A vessel surprised by them in a roadstead is liable to founder at her anchors, or, breaking from her moorings, be driven ashore. At the approach of the Cordonazo the offing should be run for, or, if obliged to remain in the roadstead, an anchorage should be chosen where it will be easy to get under way at the first sign of the tempest's striking."

Although usually occurring about the 1st of October, these tempests have been experienced as late as the 1 st of November, a fact which it is well to remember.

Currents.-The currents in the middle of the gulf set to the southeastward; they are of very little strength and are greatly influenced by the tides. Along the western shore the current, when uninfluenced by the tide, sets to the northwestward, but it is so slight as to be hardly perceptible. Off cape San Lucas the current sets to the eastward. The Narragansett experienced quite a strong easterly current off the southern extremity of the peninsula. The tides ebb and flow regularly along the coast, but their strength and direction depend greatly on the prevailing wind; the tidal current increases in strength towards the head of the gulf; at the mouth of the Colorado river they frequently run at the rate of 5 to 6 knots per hour. 
Fish.-Nearly every species and variety of edible fish found in the waters of the Mediterranean, or on the coasts of Europe, the West Indies, Atlantic North America, or Chili, are found in the waters of Lower California in greater abundance than elsewhere. Their numbers are not only incredible, but many of them are of extraordinary beauty and brilliancy of color. The missionary and discovery writers bear invariable testimony to this feature of the animal life of California.

Swordfish of immense size are found in the waters of the gulf; they have been known to attack vessels and leave their swords in the timbers.

Sharks of several species abound in every bay and harbor; among them are the thresher and the hammer-head. Some of the sharks of the upper gulf waters are said to be as large as middling-sized California whales and to weigh over 1,000 pounds. They are called tiburones, and reach a length of 30 feet; they are very ferocious, and much dreaded by pearl-divers, boatmen, and fishermen.

A singular fish found in these waters is the boops ochione, or bull'seye; it seems to be a species of sunfish, and has only one large eye, about the size of a bullock's, set in the center of the upper part of the body.

The Manta Raya, a species of ray, is an immense brute of enormous strength, cunning, and ferocity, and is more the terror of the pearl-divers than any other creature of the sea.

One measured 17 feet in width, 11 feet in length, exclusive of tail (which was armed with a spine), and over 3 feet in thickness at the middle Its mouth, armed with formidable jaws (no teeth), measured 26 inches across, occupying the space between the two singularly-shaped flaps projecting from its head like horns. Its weight was estimated at 3,000 pounds. It seems identical with the horned ray, sometimes called seadevil, of the Mediterranean.

Another inhabitant of these waters is the octopus (devil-fish), a gigantic mollusk, that is found in the rocky cavities along the shore, particularly in localities sheltered from the surf, where it lies quietly among the seaweeds watching for its prey. Its arms, which are furnished with flat disks or suckers, are from 10 to 20 feet in length. With these arms it seizes, envelops, and smothers its prey, which it afterwards devours at its leisure with its sharp, formidable bill.

Red water.-A very curious phenomenon of the gulf is the existence of extensive patches of red-colored water. This was noted by the earliest Spanish navigators, who at one time named the gulf "El Mar Verme Jo," the vermilion sea. It is believed that the first investigation and description of this phenomenon was by Assistant Surgeon Thomas H. Streets, U. S. N., of the U. S. S. Narragansett, in 1875. (See American Naturalist, February, 1878.) He makes a distinction between the vermilion patches of the mouth of the gulf and the brick-colored and corrosive waters of 
certain portions of the upper gulf. The former he assigns to the presence of countless numbers of ciliate infusoria suspended some distance below the surface of the water; the latter to the presence of great numbers of flagellate infusoria, the common Noctiluca miliaris floating on the surface of the water, giving it a milky red color.

Cabeza Ballena is a perpendicular rocky point of dark lead color from 50 to 75 feet high, with numerous detached rocks lying off it. Immediately back of the point a range of hills, one of the spurs of the Sierra de la Victoria, rises to a height of over 1,000 feet. A rocky formation, the same as that of Cabeza Ballena, extends 2 miles to the westward of it, where it joins the steep sand beach of San Lucas bay.

From Cabeza Ballena the coast for 4 miles to the northeastward is generally rocky and of moderate height; thence it recedes somewhat, and for a distance of $2 \frac{1}{2}$ miles is low and sandy, sloping gradually to a mountain range a short distance inland, called the Sierra de San Lazaro. Near the southwestern end of this sand beach are an arroyo and several ranches. After passing the strip of sand the coast is of rocky formation as far as. Palmia point.

Cerro Colorado, 602 feet high, near Palmia point, and within $\frac{1}{2}$ mile of the beach, is composed of red sandstone. It is an excellent landmark, and is the only formation of the kind between cape San Lucas and San José bay.

Palmia point is the southwestern extremity of San José del Cabo bay, and is a low, bluff, rocky point, with numerous detached rocks close to. It is backed, at a distance of 600 yards from the point, by a mound 353 . feet high. The soundings off this part of the coast showed over 100 fathoms at a distance of $1 \frac{1}{2}$ miles.

San José del Cabo bay is an open bay formed by an indentation in the coast line between Palmia and Gorda points. The shore of the bay consists of steep sand beaches, with rocky patches at either end, that toward Palmia point being the most extensive. The bay is entirely open to the south and east, and the sea breaks heavily upon its shores.

Anchorage.-Vessels may anchor anywhere in the bay at a distance of $\frac{r}{3}$. mile from the beach in from 7 to 9 fathoms water, sandy bottom, except just south of the watering place (see Chart No. 635), where there is a deep hole, with from 30 to 50 fathoms water to within 400 yards of the shore. The best anchorage is about $\frac{3}{4}$ mile to the northward of Palmia point, in 8 to 9 fathoms, abreast a short strip of sand beach about 200 yards in length, fronting a rocky formation. On this sand beach is the best hoat landing. The heavy swell that sets into the bay at all times, and particularly during the season of the SE. gales (viz, from May to October), makes this bay an uncomfortable anchorage and renders landing in ordinary ship's boats a hazardous undertaking. 
San José river waters an extensive valley of the same name, which extends many miles into the interior, and empties into the sea a little over 3 miles from Palmia point. At ordinary times the water percolates through the high sand ridge thrown up by the action of the sea, and only breaks through at the time of freshets. A mile farther to the eastward is a small outlet, which is always open, where good water may be obtained at the last of the ebb. Mount San Lazaro, 4,564 feet high, kept on a bearing N. $46^{\circ} \mathrm{W}$. (N. $56^{\circ} \mathrm{W}$. mag.), leads up to the watering place.

San Jose del Cabo.- The village is on the western bank of the river $\frac{3}{4}$ mile from the sea. The population is about 2,000; very few are foreigners.

The business of the place consists in shipping local products to the adjacent ports and to San Francisco. Some of the natives are engaged in the shark fishery and the preparation of shark oil, and it seems as though a profitable business might be done in the gathering and pressing of the castor bean, which grows wild in the vicinity in great abundance. There is also plenty of rosewood and cedar growing on the mountain sides.

The United States is here represented by a consular agent.

Supplies.-Vessels may obtain a supply of fresh meat, vegetables, and wood at moderate prices.

Steamers.--Monthly steamer from San Francisco, touching at Ensenada, Magdalena, San José, Mazatlan, La Paz, Guaymas, and return.

The valley of San José is the most fertile of Lower California. Throughout its extent are plantations of sugar cane, cotton, corn, and tobacco, while in the gardens are groves of orange, fig, lemon, lime, and pomegranate trees, while plantains and bananas are found growing by the side of every ditch or aqueduct. Here and there are seen waving groves of palm trees.

Road to La Paz and intermediate places.-There is a road winding around the numerous lateral spurs of the Sierra de San Lazaro to Santa Anita, La Palma, Miraflores, Santiago, and Los Martires, near the coast in Palma bay; thence up a cañon to San Bartolo, San Antonio, Trifuno, silver mines, and La Paz. Horses and mules for making this journey, which is somewhat over 100 miles, can be obtained at San José del Cabo at from $\$ 16$ to $\$ 20$ round trip.

Salatea.-An extensive salt marsh, known as Salatea, lies betreen the beach near the mouth of the river and the village of San José. By landing near the watering place it will be possible to procure horses to ride to the village and native guides who will point out the best places for fording the intervening water courses. Generally there will be no delay in getting horses at this point, as the natives are on the watch for parties landing, and bring them down at once. 
Gorda point is a round, rocky bluff, about 50 feet high, with many outlying rocks close to ; from it a rather flat-topped hill rises to a height of 300 feet. Near the shore, $1 \frac{1}{2}$ to 2 miles west of Gorda point, is a cluster of conspicuous hills, called Cerros Prietos. They are of conical shape and of a light-gray color, resembling small craters. They can be distinguished at considerable distance, and can not escape notice, when coming from the westward, before entering San José bay.

Coast.-Cape Pulmo lies 21 miles NNE. $\frac{1}{2}$ E. from Gorda point. The coast between them projects considerably to the eastward of the line of bearing, having a gradually sweeping convex shore line, without any intermediate prominent points that are recognizable from a distanee. It is noderately low and rocky, with occasional sand beaches, sloping gradually to the mountain range in the interior.

Polfia point, which is 3 miles northeastward from Gorda point, projects but little from the general coast line. It is low and rocky, and a heavy surf breaks upon it at all times. Porfia point, which lies 10 miles farther to the northeastward, is a bold, rocky bluff 60 feet high, which may be recognized by its light, grayish color, differing several shades from other points in the vicinity. Off this point are numerous detached rocks close to.

Shoal water.-About midway between Polfia and Porfia points, where a lateral spur of the coast range of hills terminates near a low sand beach, the water is shoal and discolored for a mile or more off shore. Soundings about a mile off shore showed a depth of 12 fathoms, increasing to $16 \frac{1}{2}$ fathoms at $1 \frac{1}{2}$ miles off. On other parts of this coast soundings at the vame distance showed 40 and 50 fathoms.

About 3 miles to the northward of Porfia point is a minor point, with a rocky bluff 60 feet high; about midway between the two points is an arroyo and ranch.

Cape Pulmo is a bold, rocky bluff of a light grayish color, 410 feet high, surmounted by a hill 850 feet high. The country between this headland and the coast range of hills is low.

Immediately south of the cape is a small bay, $\frac{3}{4}$ mile deep, at the bottom of which is an arroyo and ranch. The water in this bay and off the cape is deep, 10 fathoms and over being found within 200 yards of the beach.

Off the SE. point of the bay the sea breaks for $\frac{1}{4}$ mile off shore.

There is a small white rock, 12 feet high, $1 \frac{1}{2}$ miles northward of the cape proper, and about $\frac{1}{3}$ mile from the nearest shore to the SW.; 12 fathoms of water were found close to it.

High bluff is a rocky headland which lies 4 miles to the northward of cape Pulmo, and is from 50 to 75 feet high, surmounted by a hill 820 feet in height, which is the eastern end of a range of mountains from 1,500 to 2,000 feet high. Shoal water extends off this headland a short distance in every direction, and there are numerous detached rocks close to it; the 
coast between it and cape Pulmo consists chiefly of sand bluffs about 20 feet high, with some rocky patches and a few outlying rocks along the shore. Just south of High bluff there is a small settlement of people engaged in the pearl fishery.

Coast. - The coast between High bluff and Arena point recedes considerably, forming an open bay $1 \frac{1}{2}$ miles deep, the shores of which are sandly, and, toward Arena point, low.

At $1 \frac{1}{2}$ miles N. $16^{\circ} \mathrm{W}$. (N. $26^{\circ} \mathrm{W}$. mag.) from High bluff, and 800 yards distant from the nearest shore to the westward, is a shoal of small extent on which the sea breaks. Between it and shore is a passage with from 4 to 5 fathoms water. 'To avoid this shoal when coming from the south, after passing cape Pulmo keep it on a bearing nothing to the eastward of south (S. $10^{\circ} \mathrm{E}$. mag.) until High bluff is well on the port quarter, bearing S. $45^{\circ}$ W. (S. $35^{\circ}$ W. mag.), when you can safely haul up for Arena point. Coning from the north, keep cape Pulmo well open of High bluff, or on a bearing nothing to the east of south (S. $10^{\circ} \mathrm{E}$. mag.) until High hluff bears S. $56^{\circ}$ W.(S. $46^{\circ}$ W. mag.), when you will be well past the shoal.

Arena point is low and sandy, with a heavy surf breaking all around it ; there are no outlying dangers, and the water off the point to the eastward is very deep, no bottom being found at 150 fathoms $\frac{3}{4}$ mile off it.

Good anchorage may be found in moderate weather in from 7 to 10 fathoms water, dark sandy bottom, less than $\frac{1}{2}$ mile from the shore, Arena point bearing N. $24^{\circ}$ E. (N. $14^{\circ}$ E. mag.) distant one mile.

Caution.-In rounding this point do not approach it nearer than $\frac{1}{2}$ mile, as the soundings to the northward show only 6 fathoms, increasing rapidly from that point.

Anchorage may be obtained in moderate weather inside the point in from 6 to 8 fathoms, sandy bottom.

Palmas bay.-Between Arena and Pescaderos point, the coast falls away, forming Palmas bay, which is from 3 to 4 niles deep and $19 \frac{1}{2}$ miles between the two points. It is entirely open to easterly winds and affords no shelter from the southeasterly gales. In the northern part of the bay the hills extend to the water, with rocky cliffs and stony beaches. The southern part is less broken, the coast being low and sandy and rising gradually to the coast range of mountains.

Near Arena point there is quite an extensive plain covered with cactus and various kinds of bushes and trees; among the latter is the copal tree, which is found in many places in the southern part of the peninsula.

Soundings. - The soundings in the northern and western part of the bay show deep water close to the shore, in the southern part, between Arena point and a steep rocky point $3 \frac{1}{4}$ miles northwestward of it. Shoal water from 3 to 5 fathoms, with indications of shifting shoaler 
spots, extends $\frac{1}{2}$ mile off shore. When approaching Arena point from the northward the land should not be approached to within a mile and the lead should be kept going.

Boca Trinidad.-Several arroyos open into the bay, one of them, known as Boca Trinidad, $9 \frac{1}{2}$ miles north westward of Arena point, near a cluster of conspicuously formed hills, has an extensive ranch near it. There are several other ranches near the shore of the bay and about $2 \frac{1}{2}$ miles to the southward of Pescaderos point are the ruins of a stone building.

Pescaderos point is bold, rocky, and of a reddish color; it may be safely approached to within $\frac{1}{2}$ mile, carrying about 10 fathoms of water; the hills back of the point rise to a considerable height.

Muertos bay is very much the same in character as Palmas bay, being formed by the receding of the coast between Pescaderos and Perico points. The land back of the bay rises to a height of nearly 4,000 feet, with a gradual descent on its southern side to a sand beach, and on the northern to a broken rocky shore. The most prominent peak in the coast range of mountains, 3,768 feet high, is 9 miles N. $69^{\circ} \mathrm{W}$. (N. $79^{\circ} \mathrm{W}$. mag.) from Pescaderos point, and is not more than 4 miles from the bottom of the bay.

In the northern part of the bay the water is deep close to the shore; in the southern part anchorage can generally be had within $\frac{1}{2}$ mile of the beach in from 6 to 10 fathoms water, sandy bottom.

There are several ranches situated near the shores of the bay.

Perico point is a steep rocky bluff, of a whitish color, from 4 () to 60 feet high, back of which a hill rises abruptly to a height of 797 feet. The coast to the southeastward is of the same formation as the point for a distance of about 2 miles, where there is a small cove with a sand beach on its western and southern sides.

The soundings off the point show deep water close to; from 10 to 14 fathoms were obtained at from 200 to 300 yards off it, increasing to 135 fathoms at $\frac{1}{2}$ mile distant.

Arena de la Ventana point.-The coast north ward of the rocky bluffs of Perico point recedes a little and is low and sandy to Arena de la Ventana point, which is a low, sandy point, the eastern limit of Ventana bay and the south point of entrance to Ceralbo channel ; back of it to the westward is a low sandy plain, gradually rising as it extends inland.

Ventana bay is a large open bay lying between Arena de la Ventana and Gorda points; it is about 6 miles deep and $12 \frac{1}{2}$ miles between the two points above mentioned. The southern shore of the bay is low and sandy, with an extensive plain back of it, covered with cactus and stunted bushes. On the northwestern side the high coast hills rise more abruptly from the water's edge, forming, with the high peaks of the interior, an unbroken stretch of mountainous country extending to La Paz bay. The two high- 
est peaks, over 4,000 feet high, known as Los Cacachiles, lie $7 \frac{1}{2}$ miles in a southwesterly direction from Gorda print; they are a mile apart and visible from a great distance.

The bay is much frequented at the proper season by vessels engaged in the pearl fishery.

La Ventana is a small village, now in ruins, lying near the shore of the bay $9 \frac{1}{2}$ miles westward of Arena de la Ventana point. There is a road from the village to San Antonio (Trifuno silver mine), a distance of 15 miles; at one time the products of the mines were brought to Ia Ventana for shipment that are now taken to La Paz.

No supplies can be obtained here.

Anchorage may be found in any part of the bay within $\frac{1}{2}$ mile of the shore, in from 5 to 8 fathoms water; farther off shore the water deepens rapidly.

Gorda point, the western limit of Ventana bay, is a bold, rocky bluff 50 to 75 feet high, with high land immediately back of it. It may be safely approached to within a short distance, 5 fathoms of water being found close to.

Ceralbo island, which lies to the northward of Arena de la Ventana point, is of volcanic origin, high and barren. It is $15 \frac{1}{2}$ miles long in a nearly NW. and SE. direstion, and its greatest width is about 4 miles. It is said to contain rich copper mines. Two high peaks rise, one in the northern and one in the southern part of the island, to heights of 2,263 and 2,477 feet respectively.

The whole eastern fice of the island is a succession of bold, rocky bluffs with small stretches of gravel beach intervening, with deep water close to the shore. From the northernmost point, which is a high bluff, a reef of rocks extends off nearly $\frac{1}{2}$ mile. Small vessels, especially those engaged in the pearl fishery, frequently anchor to the eastward of and close under this point, which affords some protection from the strong NW. winds.

Seal rock.-Four miles N. $27^{\circ}$ W. (N. $38^{\circ}$ W. mag.) from the northernmost point of Ceralbo island is a rock about 100 feet long, 50 feet wide, and 12 feet above water, known as Seal. rock, from its being a favorite resort of those animals. On the northwestern side of this rock, at something less than 100 yards distant, is a smaller one that is awash at low water, and 200 yards S. $23^{\circ} \mathrm{W}$. (S. $12^{\circ} \mathrm{W}$. mag.) is a sunken rock with only 2 fathoms water over it. There are a few smaller rocks in the immediate vicinity, the whole forming a dangerous group.

Channel.-Between the above-mentioned group of rocks and Ceralbo island there is a deep channel that is helieved to be free from dangers. At $\frac{1}{4}$ mile from Seal rock 25 fathoms were obtained, increasing to over 100 fathoms at $1 \frac{1}{2}$ miles distant. 
The NW. point of Ceralbo island ends in a reef of rocks fronting a bluff point and extending off but a short distance. The western side of the island presents nearly the same appearance as the eastern-bold, rocky bluffs-wherever the steep lateral spurs of the main ridge approach the shore, with sand and gravel beaches intervening.

At $4 \frac{1}{2}$ miles from the northwestern point there is a slight indentation in the shore line, with a strip of sand beach at the bottom of the bight, known as El Limona, and 3 miles farther south a similar indentation is known as El Mostrador. The southern limit of El Mostrador is formed by a steep, high bluff of a whitish color, called Farallones Blancos; $2 \frac{1}{4}$ miles southward of this bluff is a bold, rocky point, called Carrera de los Viejos. The next point to the southward is low and sandy and forms the southwestern extremity of the island; the water off this point is very deep, but anchorage may be found on the north side of it, 400 yards distant from the shore, in 10 fathoms water. Three-quarters of a mile southeastward from the last-mentioned point is a bold, rocky point called Piedras Gordas, off which a reef of rocks extends about $\frac{1}{4}$ mile; from this point to the southeastern point of the island, which is a steep, rocky bluff, the distance is a little over 3 miles.

Montana rock is a dangerous sunken rock which has only 4 feet of water over it at low tide. It lies about $\frac{3}{4}$ mile off the southeastern point of the island. Between the rock and the island there is a clear passage with 5 and 6 fathoms water; outside the rock the water deepens rapidly to 10 fathoms and upwards. This rock, although it has not heretofore appeared on any chart, has long been well known to the native fishermen and pearl-divers.

Ceralbo channel.-Between Ceralbo island and the mainland there is a channel $3 \frac{1}{2}$ miles wide at A rena de la Ventana point, and $6 \frac{1}{2}$ miles wide at Gorda point.

Directions.-In using this channel with a steamer it is only necessary to. keep in mid-channel. The Montana Rock is the only danger that lies at any distance off shore ; that is easily avoided by keeping toward the southern side of the entrance. Do not let Los Cacachiles (before described), 4,000 feet high, bear any to the southward of west (S. $79^{\circ} \mathrm{W}$. mag.) and you will pass well to the southward of the rock.

The above directions apply equally well to a sailing vessel having a fair wind. With a head wind they should not attempt to pass through the channel, as the tides run with considerable force, sometimes $2 \frac{1}{2}$ knots per hour, and nothing would be made beating against them. Calms are also frequent in the channel, and as a rule sailing vessels bound to La Paz will do better to go well outside of Ceralbo island.

Caution.-Unless well acquainted with the coast, it is not advisable to attempt to pass through the channel at night or in thick weather. 
Coast.-The coast between Gorda point and Coyote point, a distance of $16 \frac{1}{2}$ miles, is generally bold and rocky, with occasional sand beaches. Back of the coast the country is broken and mountainous.

La Luz point is $2 \frac{6}{10}$ miles northwesterly from Gorda point, the coast between being steep, with a succession of bluffs. Two miles farther, in the same general direction, is a rocky point, with a reef of rocks extending off nearly $\frac{1}{4}$ mile; fresh water may be obtained near this point. Following the coast for $3 \frac{3}{4}$ miles from the last-mentioned point, we come to Santa Cruz point, a bluff point, outlying from which are a large white rock and several smaller ones.

Rosario bay is an open bay formed by an indentation in the coast line between Santa Cruz point and the next point to the northwestward. At the deepest part of the bight, near the shore of the bay, is a ranch known as San Rosario. Just north of this ranch a shoal extends a short distance off the coast. The soundings in the bay are from 3 fathoms at 200 yards from the shore to 10 fathoms $\frac{1}{2}$ mile off. The northern end of the bay is formed by a rocky bluff, with a conspicuous hill 984 feet high just back of it. From here to Coyote point is $5 \frac{3}{4}$ miles, the coast line curving inward somewhat, and the hills receding considerably from it. Before reaching Coyote point, when coming from the SE., a bold rocky bluff with moderately high hills is passed. This bluff is frequently mistaken for Coyote point, which is somewhat over $\frac{1}{4}$ mile northwestward from it.

Coyote point is the southeastern point of the entrance to San Lorenzo channel; it is moderately low and rocky, with a small outlying white rock close to, and a reef of rocks extending a little more than 200 yards off the point.

Las Galeras.-Two miles to the westward of Coyote point a shelving rocky ledge called Las Galeras makes off from a bluff point, in a WNW. direction, $\frac{1}{4}$ mile.

Arranco Cabello point is a steep rocky projection, just back of which is a hill 164 feet high, lying about a mile to the westward of Las Galeras. A small shoal with but $1 \frac{1}{4}$ fathoms water lies 600 yards to the northwestward of this point; between the shoal and the point is a passage with $2 \frac{3}{4}$ fathoms water.

San Lorenzo channel, which separates Espiritu Santo island from the mainland southward of it, is $3 \frac{1}{2}$ miles wide at its narrowest part, but on account of the dangerous shoals and rocks in it must be navigated with the greatest caution.

Scout shoal is a dangerous shoal on which there is, in the shoalest part, only $1 \frac{3}{4}$ fathoms water. It lies $1 \frac{1}{10}$ miles N. $30^{\circ} \mathrm{W}$. (N. $40^{\circ} \mathrm{W}$. mag.) from Arranco Cabello point and is nearly circular in form, having a diameter of $\frac{1}{4}$ mile; the bottom is rocky, being composed chiefly of loose stones. There 
is generally a buoy on its northwestern side. Between this shoal and the one previonsly mentioned as lying off Arranco Cabello point there is a passage $\frac{1}{4}$ mile wide, with 4 fathoms of water.

San Lorenzo reef is a rocky ledge lying $1 \frac{1}{4}$ miles N. $13^{\circ} \mathrm{W} .\left(\mathrm{N} .23^{\circ} \mathrm{W}\right.$. mag.) from the shoalest part of Scout shoal; its northwestern limit is about the same distance S. $39^{\circ}$ E. (S. $49^{\circ}$ E. mag.) from Lupona point. It is 800 yards in length in a general SE. and NW. direction by 500 yards in width ; the least depth of water, near the center, is $4 \frac{1}{2}$ feet. Between it and Lupona point there is a clear passage $\frac{3}{4}$ mile wide, through which 4 fathoins may be carried.

Suwanee rocks lie $\frac{1}{2}$ mile N. $52^{\circ}$ E. $\left(\right.$ N. $42^{\circ}$ E. mag.) from the shoalest part of San Lorenzo reef. The patch is small in extent and has in its shoalest part only one foot of water at low tide; all around it, close to, are 5 and 6 fathoms of water.

Buoys.-June, 1890, two new buoys were placed in San Lorenzo channel, replacing the old buoys marking the south extremity of San Lorenzo reef and the north extremity of Scout shoal.

These buoys are small and can not be seen at a distance greater than one mile.

Directions.-From the north point of Ceralbo island, approach San Lorenzo channel on a course or bearing of N. $89^{\circ} \mathrm{W}$. (S. $81^{\circ} \mathrm{W}$. mag.) which should lead about half-way between the land on each side of the middle point between the shoals. Take the danger angle $93^{\circ}$ on the sextant and steer so as to keep Coyote point, or the bluffs just east of that point, and San Lorenzo point, or where it opens Diaslo point (or, say the extremes of land seen to the southward) subtending this angle, taking care not to get above $99^{\circ}$ or below $88^{\circ}$. This will lead through the channel between the shoals. In coming out from La Paz bay, pass about $\frac{3}{4}$ mile west of Lobos rock, and steer for Bonanza point (Espiritu island) with Lobos point just open. When the eastern end of Ballenas island closes with Prieta point, put the helm hard over and steer N. $55^{\circ}$ E. (N. $45^{\circ}$ E. mag.) and then use the same danger angle as before.

Caution.- The buoys for San Lorenzo channel are not to be depended upon. The width of the channel subtends an angle of only $3^{\circ}$ at north point of Ceralbo island, 21 miles distant, and as an error of less than $2^{\circ}$ in the course indicated on $\mathrm{H}$. O. chart No. 42 might put a vessel on one of the shoals, the use of the danger angle on the sextant is advisable.

Winds.-The winds in the channel are regular during the greater part of the year, blowing from a northwesterly direction from 9 a. m. until 4 p. m., and succeeded toward evening by a southerly wind, which lasts all night.

La Paz bay.-San Lorenzo channel is the eastern entrance to the large bay of Laz Paz, which is nearly 40 miles long, north and south, and from 
16 to 20 miles wide. It has a good depth of water throughout its extent, and is believed to be free from hidden dangers. The town of $\mathrm{La} \mathrm{Paz}$ is situated in its southeastern part.

Tides.-The tide runs with considerable force, sometimes $2 \frac{1}{2}$ knots an hour; from October to February, it runs at the rate of 3 knots. Calms are frequent in the spring and summer months.

San Lorenzo point is the northwestern extremity of the peininsula that forms part of the eastern shore of $\mathrm{La} \mathrm{Paz}$ bay. It is a moderately high bluff, with no dangers off it.

Diabolo point lies about $1 \frac{1}{4}$ miles southwestward of San Lorenzo point and is a sharp, rocky bluff, with deep water close to.

Puerto Ballandra.-Between Diablo and San Lorenzo points the shore line recedes about $\frac{3}{4}$ mile, forming a small cove, called puerto Ballandra. At the entrance of this cove there are 12 fathoms water, and the 3 -fathom curve is about 700 yards inside of a line drawn between two points; inside the 3-fathom curve it is full of rocks and shoals.

Lobos rock lies $1 \frac{1}{4}$ miles S. $16^{\circ} \mathrm{W}$. (S. $6^{\circ} \mathrm{W}$. mag.) of Diablo point. It has a broken surface and is 12 feet high. The water is deep close to, and between it and the shore to the westward there is a passage $\frac{1}{2}$ mile wide.

There is a small cove or indentation in the shore to the eastward of the rock, with from 2 to $2 \frac{1}{2}$ fathoms of water, which would afford good shelter for a few small, light-draft vessels.

Lobos island lies $\frac{3}{4}$ mile to the southeastward of Lobos rock and $\frac{1}{8}$ mile from the mainland. It is about $\frac{1}{4}$ mile long and $90^{\circ}$ feet high. A light deposit of guano on its surface gives it a whitish color, by which it may le easily recognized. On its western side the water is deep close to.

San Juan Nepomucino island, which is $1 \frac{1}{2}$ miles long, north and south, byabout 600 yards in width and 60 feet high, forms the harbor of Pichi* ilnque, which lies between it and the mainland to the eastward. The western shore of the island is a steep bluff with 5 fathoms water to within 200 yards of the land, except at a point 800 yards from the northern end, where there is a rock awash, 200 yards distant from the shore. Fifty yards outside the rock there are 5 fathoms of water. The bluff character of the western shore terminates near the southern end of the island in a gravel beach which extends around the southern end. Near the SE. point, which is a rocky bluff, is a small hill 70 feet high, its western side sloping to a salt lagoon about 600 yards in length by 400 yards in width, which yields by the natural evaporation large quantities of salt. The eastern side of the island is for the most part a shelving sand and gravel beach. The United States Navy Department has a coal depot near the southeastern end of the island. In 1892 there were about 700 tons, nearly all of which had been exposed to the weather. There is a good tool house here. 
The watchman has a dwelling near the coal shed. A temporary landing place has been made, and the coal is transported in small lighters.

Lighters may be hired at $\mathrm{La} \mathrm{Paz}$ at from $\$ 10$ to $\$ 15$ per day. The ship using them has to bring them from La Paz, also return them. If men are desired to coal ship they can be obtained at Ia Paz at a cost of $\$ 1$ and $\$ 1.50$ per day. They coal ship at the rate of 8 tons per hour.

It is necessary to take a pilot for La Paz. They are reliable and charge $\$ 25$.

Pichilinque harbor, as before stated, lies between San Juan Nepomucino island and the mainland to the eastward of it. Although small, it is one of the best harbors on the coast, being well protected on all sides.

The entrance is from the southward, the northern end of the island being connected with the mainland by a shoal, over which there is only 3 feet of water. It is unnecessary to give any directions for entering the harbor, as the passage is clear with 3 fathoms of water to within 50 yards of the shore on either side, deepening to $4 \frac{3}{4}$ and $5 \frac{1}{2}$ fathoms midway between the heads. In rounding the southern end of San Juan Nepomucino island, give it a berth of $\frac{1}{4}$ mile, as the shoal water makes off a little from it.

Water.-Tolerably good water may be obtained in small quantities from a well situated in a valley on the eastern shore of the harbor.

Remarks. - In case of contagious disease at La Paz (a rare occurrence), or for vessels drawing over 20 feet of water, which can not, even at high water, pass through the channel to that place, Pichilinque harbor affords an excellent anchorage, whence communication can easily be kept up by means of boats, the wind being fair to go to $\mathrm{La} \mathrm{Paz}$ during the greater part of the day, and fair to return toward evening and during the night.

False bay.-Immediately south of the eastern point of the entrance to Pichilinque harbor is a cove about $\frac{3}{4}$ mile in extent NE. and SW., known as False bay, having in its outer part 5 and 6 fathoms of water.

Colorado point is the first point to the southward of the entrance to Pichilinque harbor, and is a bold, rocky bluff, of a reddish color, about 50 feet high. For a distance of nearly 200 yards off the point there are numerous outlying rocks. South of Colorado point is a small bay, formed by indentations in the coast line, which is full of shoals and coral reefs.

Prieta point is at the entrance to the channel leading to La Paz. It is a sharp perpendicular bluff of gray color, 32 feet high, the land rising gradually back from it. There are some outlying rocks near the point, and shoal water, with rocky bottom, extends off it about $\frac{1}{4}$ mile in a southwesterly direction. Two and nine-tenths miles N. $69^{\circ}$ E. (N. $59^{\circ}$ E. mag.) from the point is a hill 1,527 feet high (the highest in the vicinity), on the very top of which is a conspicuous single tree.

La Paz channel.-From Prieta point to La Paz, by way of the channel, is $3 \frac{1}{2}$ miles. Vessels of 16 feet draft may enter and navigate La 
Paz channel at any stage of the tide, but should always take a pilot, as the channel is narrow and tortuous, with steep banks on either side; the water in some places shoaling from 3 fathoms to 3 or 4 feet within a distance of 20 yards. In 1890, five new buoys were placed in the channel, replacing the old buoys.

If obliged to enter and pass up the channel without a pilot, an experienced eye aloft and the lead are the only guides that can be depended on; from aloft the deep water of the channel ahead can be readily distinguished, as well as the projecting points of the shoals on either side; the lead should be kept going constantly on both sides of the vessel.

About a mile to the southward of Prieta point there is an entrance to the channel through which $1 \frac{1}{4}$ fathoms may be carried; it is not over 100 yards wide, but is much used by the small coasters. To pass through it, being outside in from 6 to 10 fathoms of water, bring the north part of a large detached rock that lies on the eastern side of the channel (the only one in the vicinity) to bear S. $57^{\circ}$ E. (S. $67^{\circ}$ E. mag.) and steer for it. This course will lead through the center of the passage; when in 3 fathoms water, after having passed over the shoal, haul to the southward. When the rock is on the bearing given above, a hill 836 feet high .will be iust open to the southward of it.

Anchorage.-When waiting for a pilot, vessels may anchor anywhere to the southward of Prieta point in from 7 to 10 fathoms. The best anchorage at $\mathrm{La} \mathrm{Paz}$ is from 200 to 300 yards in a westerly direction from the wharf, in $3 \frac{1}{2}$ fathoms water, sandy bottom. Vessels drawing less than 12 feet can lie at the end of the wharf.

After passing La Paz, the channel curves to the westward and terminates in a large lagoon that lies in a low, almost level plain, covered with a thick growth of trees, bushes, and cactus. The water in the greater part of this lagoon is shoal, but there is a channel with from 2 to 3 fathoms leading to its northwèstern limit.

El Mogote.-The harbor or anchorage of $\mathrm{La} \mathrm{Paz}$ is protected on its northern and western sides by a low peninsula about 5 miles long in an east and west direction, and $1 \frac{1}{2}$ miles wide at its widest part, called $\mathrm{El}$ Mogote. It is for the most part sandy and covered with scattered shrubs and bushes.

Passage. - There is a boat passage with a scant fathom of water at low tide, which, passing near the NE. point of El Mogote, enters the main channel opposite La Paz.

Directions.-To pass through it bring a conspicuous red-brick house (the northern one of two situated to the northward of the cathedral and back of a sand bluff 28 feet high), just open of the NE. point of El Mogote, the house bearing S. $54^{\circ}$ E. (S. $64^{\circ}$ E. mag.), and stand in, keeping the house just open of the point until nearly up with the latter, when you 
will be in about 3 fathoms of water; from this point follow the shore of El Mogote at a distance of 150 to 200 yards until you can look up the street leading from the wharf at La Paz, when you may steer for the wharf. This passage is very convenient for vessels anchored north of $\mathrm{El}$ Mogote, as it affords a short cut for boats to and from the town.

La Paz, with a population of about 5,600, is the largest and most important town of Lower California as well as the seat of government for the southern district of the peninsula. This district extends from El Rosario, in latitude $28^{\circ}$, to cape St. Lucas, and is governed by a governor and local authorities.

The principal part of the business center is built on low, flat ground, but many of the fine residences, the cathedral, government house, barracks, and private dwellings are situated on a high table land back of the town, now the best portion of the city. There is a small police force and a regular garrison of 200 men.

The United States is represented by a consul and vice-consul.

Pilots.-There are two government pilots who are reliable and necessary. Pilotage in or out, $\$ 1.75$ per foot draft.

Port Charges.-Captain of port fee, $\$ 3.50$; bill of health, $\$ 4.25$; stamps for entry of manifest, $\$ 8.50$; stamps for clearance, $\$ 1$; tonnage fee, at the first port of entry only, $\$ 1.50$.

Note.-The tonnage measurement of the United States merchant vessels paying the fee is collected according to register. When a vessel brings in port part of the cargo in coal and the rest in merchandise, tonnage fee is collected on merchandise only.

Climate.- The climate is healthy, though the place has once been visited by yellow fever, in 1883, when it spread over the Pacific coast. The thermometer ranges in winter from $50^{\circ}$ in the morning to $74^{\circ}$ in the afternoon, and from June to October $80^{\circ}$ to $94^{\circ}$; the rainy months are the most unhealthy.

Quarantine, when established, is strictly enforced by a sanitary commission appointed by the Federal Government; vessels are boarded by the board of health before any other port or custom officials are allowed said privilege or any communication can be had with the town. A large and commodious hospital has recently been erected and is now open to the public and marine service. Two official surgeons are in attendance.

Súpplies.-Fresh provisions, at moderate prices and good quality, can be procured. Beef, 10 cents per pound; vegetables and fish are very reasonable; potatoes in the spring are raised around the country and sold at 4 cents per pound; when imported, at 6 and 7 cents.

Water may be obtained at a moderate price, although the supply is. somewhat limited. It is pumped from wells on the higher ground back 
of the town and carried by pipes to the end of the wharf, where casks can be filled.

Commerce.-The imports are principally from the United States. The exportsaresilver ores, bullion, hides, orchilla, and pearls. A new tariff went into effect on November 1, 1891, since favorably modified.

Lights.-On the wharf at $\mathrm{La} \mathrm{Paz}$ are shown two leading lights, visible from 2 to 3 miles. One is red and the other green.

Communication.-Two regular mail lines of steamers call at $\mathrm{La} \mathrm{Paz}$ and way coast ports; the Pacific mail steamer Newburn connects monthly with way gulf ports, leaving San Francisco the first of each month for Ensenda, Magdalena bay, cape San Lucas, San José; Mazatlan, La Paz, and Guaymas, and the Mexican steamer Alejandro makes semimonthly trips, touching at gulf ports and Altata, San Blas, Chamela, and Manzanillo.

The bay, from the eastern end of El Mogote, the southern shore of the bay, for a distance of about 8 miles, trends nearly west, and is low and sandy, covered at a short distance from the beach with shrubs and bushes; for 6 miles farther, sand hills, varying in height from 15 to 75 feet, are found, the coast line curving gradually to the northwestward. Throughout this distance a series of sand shoals extends off the coast for neariy a mile, the soundings over them varying from $\frac{3}{4}$ fathom to 3 fathoms.

At $14 \frac{1}{2}$ miles from the eastern point of $\mathrm{El}$ Mogote the character of the coast changes, and it assumes a more northerly direction. From this point it presents a long unbroken range of table land from 500 to 1,000 feet high, ending in almost perpendicular cliffs from 50 to 100 feet in height, interspersed with shingle beaches. Five and a half miles south of Coyote point, which is a perpendicular, white, rocky bluff 150 feet high, there is a small ranch called San Juan, situated back of a stretch of low shingle beach. A conspicuous dark-colored peak, 1,431 feet high, lies just back of the ranch to the westward. The soundings off this part of the coast show a depth of 15 to 20 fathoms at a distance of 2 miles from the shore.

North of Coyote point the coast recedes considerably, the bluffs gradually decrease in height, and their place is taken by sand beaches backed by sand hills. A short distance inland a range of table mountains, broken by deep cañons, rises abruptly to a height of from 1,500 to 2,000 feet. As Mechudo head is approached the main range of table mountains is nearer the coast, and perpendicular bluffs from 150 to 200 feet high replace the sand beaches.

Mechudo head is considered the northern limit of $\mathrm{La} \mathrm{Paz}$ bay. It is a bold, perpendicular, stratified cliff about 300 feet high, surmounted by a dome-shaped hill 750 feet in height. Three and a half miles nearly due west from the headland is Mechudo mountain, 3,672 feet high, the only 
prominent peak in the range of table mountains before spoken of; it is visible upwards of 50 miles, and, with the prominent headland, makes an excellent landmark in the navigation of the gulf.

Espiritu Santo island forms part of the eastern shore of $\mathrm{La}$ Paz bay It is of volcanic origin, with numerous peaks, the highest of which is 1,970 feet high, 12 miles long, and from 2 to 4 miles wide. Copper mines of great value are said to exist on it.

Lupona point is the southern extremity of the island and is low and sandy; toward the hills to the northward there are a few scattered bushes. Between it and Bonanza point, which is the next point to the northeastward, the coast consists of alternate sand beaches and bluffs. North of Bonanza point, which is a rocky bluff with a flat-topped hill of moderate elevation just back of it, the coast is a succession of white sand cliffs for about $1 \frac{3}{4}$ miles; at this point there is a mound of bowlders close to the shore, and the coast line makes a sharp turn to the east for $\frac{1}{2}$ mile, when it turns again sharply to the north; off the point formed by this last sudden change in the direction of the coast line there is a reef of rocks, many of which are above water, extending off $\frac{1}{4}$ mile; in the bight scuthward of this point, anchorage may be found in 5 or 6 fathoms, protected from the northwesterly winds.

Lobos point is the easternmost point of Espiritu Santo island, and is a high, rocky bluff, with the land rising abruptly back of it; deep water extends close up to the shore. From Lobos point the coast falls away, trending about NW. to the north end of the island; it is generally bluff, with short stretches of sand beach. About 4 miles to the northwestward of Lobos point there is a rocky point, off which a reef of rocks extends $\frac{1}{4}$ mile. At this point the general coast line is broken by an indentation $1 \frac{3}{4}$ miles deep and a mile wide at its outer part, which, with a corresponding indentation on the western side, nearly divides the island.

Isla Partida is the name given to that portion of the island lying north of the two indentations or coves just spoken of. It is joined to the main part of the island by a neck of land less than 300 yards wide and of moderate height. The northern point of the island is a rocky bluff.

Los Islotes are three rocky islets lying about $\frac{1}{2}$ mile off the northern point of the island. Two of them are from 50 to 60 feet high, with perpendicular sides and flat tops; the third is merely a large rock about 5 feet above water, lying to the westward of the other two; they are separated from each other and from the island by narrow channels, navigable only by boats.

The western side of Espiritu Santo island is in its general character similar to the eastern side, rocky bluffs predominating. About $2 \frac{1}{2}$ miles from the north end is a small inlet known as "El Cardonal;" $\frac{3}{4}$ mile far- 
ther south is the cove or indentation already mentioned in connection with a similar one on the eastern side of the island. In the cove on the west side there is said to be snug anchorage for small vessels.

Ballenas island lies about midway between the northern and southern ends of Espiritu Santo island, separated from it by a channel a little more than $\frac{1}{2}$ mile wide, with from 3 to 8 fathoms water in it. It is about $\frac{3}{4}$ mile long in a nearly east and west direction and $\frac{1}{4}$ mile wide; its highest point is 228 feet above the sea level. It is entirely barren and surrounded by rocky bluffs.

Gallo and Gallina are two small islands lying a short distance to the southeastward of Ballenas island. Between them and the western shore of Espiritu Santo is a partially protected anchorage which is frequently used by the coasting vessels.

Prieta point.-Two miles to the southeastward of the southernmost of the above-named islands is Prieta point, which is a sharp, bluff point of dark color, descending in several steps from the hills behind it.

San Gabriel bay.-Between this point and the next one to the SE. is a bay of considerable extent, but with very shoal water except in its outer portion. It is known as San Gabriel bay; vessels anchoring there should be careful to keep outside of the 5 -fathom curve.

Dispensa point is the southwestern extremity of Espiritu Santo island and is a rocky bluff of moderate elevation; $\frac{1}{3}$ mile to the northward of it is a conspicuous red mound 213 feet high, composed of lumps of lava.

Shoal.-Between Dispensa and Lupona points a shoal makes off a short distance from the land, less than 3 fathoms being found at $\frac{3}{4}$ mile distant from it.

Winds.-From May to November in the bay northwesterly winds prevail during the day, succeeded during the night by light airs from the southeastward. During the remainder of the year winds from SE. to SW. prevail day and night.

San Josef channel, which lies between the islands of San Josef and San Francisco on the east and the mainland of the pennisula of Lower California on the west, is 20 miles long with an average width of about 4 miles. It is $2 \frac{1}{2}$ miles wide in its narrowest part, near the northern entrance. It is much used by sailing vessels when beating up the gulf, as by working: through it they avoid the heavy sea found outside, and are able to take advantage of the strong tides which set through the channel. In case of bad weather they can anchor in some one of the numerous bights and coves that are found on both sides of it and find shelter. In using this channel at night or in thick weather, it is recommended to keep well over toward the western shore, as there are no outlying dangers on that side. The tides set strongly through the channel, varying from one to 3 knots. 
The coast for a short distance north of Mechudo head retains its character of high, perpendicular cliffs. A bout $1 \frac{1}{2}$ miles north of the headland the cliffs are replaced by a sand beach which, with the exception of one short bluff, extends northward a distance of $4 \frac{1}{2}$ miles, or within $1 \frac{1}{2}$ miles of San Evaristo point.

Two miles to the southward of San Evaristo point, a low, sandy point makes out a short distance, immediately south of which is good anchorage in 5 or 6 fathoms, $\frac{1}{2}$ mile from the beach. There is another anchorage immediately south of San Evaristo point, where a sudden change in the direction of the coast line forms a cove about $\frac{3}{4}$ mile deep with a sandy beach at its head. Between this sand beach and the long stretch ( $4 \frac{1}{2}$ miles) before mentioned, there is a mile of rocky bluffs from 20 to 50 feet high.

San Evaristo point is a rocky headland 130 feet high projecting $\frac{3}{4}$ mile from the general coast line. There is a ranch near the beach of the bight on the northern side of the headland.

From San Evaristo point to Nopolo point, a distance of $6 \frac{7}{10}$ miles, the land is high and precipitous, with occasional short stretches of sand beach. The soundings show deep water close to the shore. At $1 \frac{1}{4}$ miles to the southward of Nopolo point there is a slight indentation in the coast line and an estero, where it is said fresh water may be procured.

Nopolo point is a rocky cliff with a rugged peak, 1,578 feet high, immediately back of it. A succession of rocky bluffs from 400 to 500 feet high extend about $3 \frac{1}{4}$ miles northwestward from the point.

San Francisco island lies on the east side of the southern entrance to San Josef channel. The island is of an irregular shape, having an area of about $1 \frac{1}{2}$ square miles. Its shores consist for the most part of rocky bluffs varying in height from 20 to 150 feet, with intervening sand beaches. The SE. end of the island is a rocky head 300 feet high, connected with the main body by a low, sandy neck. Off the northern and southern points there are numerous outlying rocks, and in a bight on its eastern side there is a rock 4 feet high 200 yards from the shore.

Anchorage may be found in from 5 to 10 fathoms off a sand beach that lies just west of the southeastern head.

Soundings around the island show from 3 to 9 fathoms close to, except on the NW. side, where it is shoal; $2 \frac{1}{2}$ fathoms being found at $\frac{1}{4}$ mile from the shore.

Channel.-Between the islands of San Josef and San Francisco there is a channel $1 \frac{3}{10}$ miles wide, with from 4 to 6 fathoms water, but a group of rocks in the center called Coyote rocks, and another group just beyond its western limit called Seal rocks, make it very dangerous, and its passage should never be attempted unless in an emergency.

Coyote rocks, the highest of which is 40 feet high, lie $\frac{3}{4}$ mile $\mathrm{NW}$. of the northern point of San Francisco island, the channel between having 
from 3 to 5 fathoms water. The channel between the rocks and San Josef is less than $\frac{1}{2}$ mile wide, with from 6 to 7 fathoms water. There are some outlying sunken rocks to the north of the main group. If obliged to pass between San Josef and San Francisco islands, it is safest to keep the shore of San Josef close aboard.

Seal rocks lie $1 \frac{3}{4}$ miles west of the north point of San Francisco island, and consist of two flat rocks about 5 feet above the surface of the water, with several outlying ones below the surface. The soundings between them and the point, as well as between them and the Coyote rocks, show a depth of 11 fathoms.

San Josef island is of volcanic origin, $16 \frac{1}{2}$ miles long and from 2 to 6 miles wide, being narrowest at its northern end, which terminates in a sharp point. It is rather higher than Espiritu Santo, some of its peaks having an altitude of over 2,000 feet. It is covered in most parts with vegetation, especially on the high land in the numerous deep arroyos of its northeastern portion.

From the southeastern point of the island, the south coast, which is for the most part a sand beach, with hills from 100 to 500 feet high back of it, trends about W. by S. for $3 \frac{6}{10}$ miles to the southwestern extremity, which is a low sand spit making out $1 \frac{1}{4}$ miles from the body of the island. A lagoon of considerable size extends to within $\frac{1}{2}$ mile of the point, having an opening to the sea on the northern side of the sand spit.

From the southwestern point, which may be approached close to, there being 20 fathoms water within 200 yards of it, the coast turns sharply to the northeastward, trending in that direction for about $1 \frac{1}{2}$ miles, where the rio San José empties its waters; thence it assumes a northwesterly direction.

Amortajada bay, which is formed by the receding of the çoast line between the southwestern point of the island and Salinas point, is about 4 miles in extent between the two points and $1 \frac{1}{2}$ miles deep from a line drawn between them. In its southern part there is good anchorage in 7 or 8 fathoms water, protected from every wind, especially from the dreaded Cordonazos or southeasterly gales. Smelting works are located near by on the shore of this bay.

Fresh water may be obtained here.

Cayo island is a small islet lying 1,600 yards N. $50^{\circ} \mathrm{W} .\left(\mathrm{N} .60^{\circ} \mathrm{W}\right.$. mag.) from the southwestern extremity of San Josef, and protects to a considerable extent the anchorage in Amortajada. bay from the northwesterly winds. It is about $\frac{1}{4}$ mile long and 100 yards wide. It is 40 feet high at its southern end, and from 10 to 15 feet at the northern, with a break near the center, over which the sea washes at high water. A reef extends off from the northern end about $\frac{1}{4}$ mile. 
Salinas point is sandy, with a steep sand hill 50 feet high immediately back of it. It lies nearly due east from San Evaristo point, the channel between them being 3 miles wide. Near the point are two lagoons, which produce large quantities of salt, the land back of then rising in broken ridges to a height of 1,830 feet. For a distance of 31 miles north ward of the point the coast is a low sand beach, at the northern end of which is a ranch. Nearly east of this ranch the island attains its greatest elevation in a conspicuous knob of the main riage that is 2,078 feet high. For 2 miles north of the ranch, steep hills rise immediately from the water. Winding between them, its mouth about a mile north of the ranch, is a deep arroyo which extends half way across the island. At the end of 2 miles the coast again becomes a low sand beach, which, with the exception of one bluff, extends to a point opposite Nopolo point. This is the narrowest part of the channel, it being only $2 \frac{1}{2}$ milts wide between the points.

Anchorage.-Southward of the above-mentioned point is a bight, formed by the sudden change in the direction of the coast line, where good anchorage may be found in from 6 to 12 fathoms, 200 to 300 yards from the shore. The land back of the coast, which for 3 or 4 miles to the southward has been lower, commences here to rise again. Anchorage may also be had north of the point.

Just north of the point is a lagoon which has a shallow opening to the sea. Thence to the north point of the island, a distance of about 4 miles, the coast trends nearly north, and is an unbroken line of steep, rocky bluffs of dark color. A reef of rocks, some of which are above water, extends off from the northern end of the island about $\frac{1}{4}$ mile. At $1 \frac{3}{4}$ miles from the northern extremity is a sharp peak 1,382 feet high, whose sides descend steeply to both shores.

No detailed examination of the eastern side of San Josef island has been made. It is in general a succession of high rocky bluffs, with some intervening sand beaches.

Red point, which is $8 \frac{8}{10}$ miles from the northern extremity of the island, is the first prominent point from that extremity, the intermediate coast receding somewhat.

Southeast point.-From Red point to the southeastern extremity of the island, a distance of 9 miles, the general trend of the coast is S. by E. $\frac{1}{4}$ E. There are several outlying rocks off the southeastern point, and a hill 400 feet high rises abruptly just back of it. For a distance of 5 miles northward from the point the coast is a series of inaccessible bluffs from 50 to 500 feet high.

Soundings.-The soundings along the eastern side of the island show a depth of over 50 fathoms a short distance from the shore.

Las Animas are a group of rocky islets not over $\frac{1}{4}$ mile in extent, including the several outlying rocks; the largest and highest is about 90 
feet high. They lie $10 \frac{1}{2}$ miles N. $87^{\circ}$ E. (N. $77^{\circ}$ E. mag.) from the north point of San Josef, and between them and the island there is a deep clear channel.

Coast.-The coast north of Nopolo point, between it and San Telmo point, recedes considerabiy, and is a succession of rocky bluffs, with intermediate sand beaches and deep ravines. A range of mountains alout 2,500 feet high lies immediately back of the coast, and several prominent islands and rocks lie off it.

Two miles northwestward of Nopolo point there is a conspicuous, broken, rocky cliff from 300 to 500 feet high, projecting slightly from the general coast line, which is known as Los Burros. Deep water extends close up to the cliff.

Three miles farther up the coast is another point of similar character to Los Burros, which is known as Dolores point. Northward of the point a slight indentation in the coast line forms Dolores bay. Near the point is a ranch, and a fertile slope, green with vegetation, stretches away toward the mountains. The point and bay take their name from the old mission Virgen de Dolores, which is situated a few niles inland. A conspicuous red-colored rocky bluff marks the northwestern limit of Dolores bay.

Habana island, which is a barren rock about $\frac{1}{2}$ mile long east and west, $\frac{1}{4}$ mile wide, and 90 feet high, lies $2 \frac{1}{4}$ miles north of the red bluff above mentioned and $8 \frac{3}{4}$ miles N. $80^{\circ} \mathrm{W}$. (west mag.) from the north point of San Josef. It is covered with white guano, and between it and the nearest point of the mainland there is a channel a little over a mile wide, from 10 to 17 fathoms of water. West of Habana island is a small indentation in the coast line, with a gravel beach (sometimes known as Tambaliche roads), back of which is an open valley.

Moreno rocks lie $5 \frac{1}{2}$ miles N. $30^{\circ} \mathrm{W}$. (N . $40^{\circ} \mathrm{W}$. mag.) from Habana island and $\frac{1}{2}$ mile from the nearest shore. Between them and the mainland the water is shoal. The highest and largest of these rocks is 40 feet high, and has a reef of rocks above and below water, extending about $\frac{1}{4}$ mile in a southeasterly direction from it. On the nuainland, about 2 miles to the southward of the rocks, there.is a lagoon.

The coast in this vicinity is a pebble beach, with occasional bluffs of a yellowish and reddish color, from 10 to 25 feet high. A prominent mountain 2,534 feet high, lying $4 \frac{1}{2}$ miles from the coast, makes a good landmark in this part of the gulf.

Black rock, 55 feet high, lies $2 \frac{1}{4}$ miles northward of the Moreno rocks and about a mile from the shore of the mainland. The passage between the rock and the mainland is apparently safe for small vessels.

San Carlos bay.-The coast north of Black rock recedes somewhat, forming the open bay of San Carlos, which affords good anchorage in from 
5 to 7 fathoms water. At the bottom of the bay there is a narrow entrance to a lagoon, with a sand beach on either side.

San Telmo point is a sharp, rugged point 30 feet high, projecting $\frac{1}{4}$ mile from the coast. There are numerous outlying rocks off it, close to. The bluffs on either side are of a reddish color. Nearly west, $6 \frac{4}{10}$ miles from the point there is a conspicuous table mountain 2,818 feet high.

San Diego island, the center of which lies $5 \frac{1}{2}$ miles N. $6^{\circ}$ E. (N. $4^{\circ}$ W: mag.) from the north point of San Josef, is nearly a mile long NE. and SW., and its highest point is 722 feet above the sea level. A reef of rocks, many of which are above water, makes off $\frac{8}{10}$ mile from its southwestern point, ending in a small rock awash, close to which 4 and 5 fathoms were obtained. Nearly $\frac{1}{2}$ mile farther off, in the same general southwesterly direction as that of the reef, $3 \frac{1}{2}$ fathoms were found ; thence the soundings increased suddenly, 140 fathorns being found within a mile. The sea generally breaks over the reef.

Passage.-There is an apparently clear passage nearly 4 miles wide between San Diego and San Josef islands, with from 30 to 44 fathoms water midway; but it should be used with caution, as it has not been thoroughly examined.

Santa Cruz is a high, barren, rocky island $3 \frac{3}{4}$ miles long, in a general NE. and SW. direction, about $1 \frac{1}{4}$ miles wide and 1,500 feet high. Its eastern face is inaccessible, consisting of high, bold bluffs from 300 to 1,000 feet high. Its NE. part terminates in a sharp point. On the western face it slopes at an angle of $45^{\circ}$ to the shore. The only landing place is at the SW. extreme, where there is a short stretch of gravel beach.

Channel.-Between Santa Cruz and San Diego there is a channel $3{ }_{1}^{6} \sigma$ miles wide which is apparently free from all dangers. No bottom was found at 100 fathoms midway between the two, and 195 fathoms, sand bottom, $1 \frac{1}{4}$ miles from Santa Cruz.

Coast.-The coast between San Telmo and San Marcial points, a distance of 14 miles, is nearly straight; it is in general rocky, with bluffs from 75 to 350 feet high, and a few short stretches of sand beach. The water is deep close to, from 10 to 30 fathoms and over being found within $\frac{1}{2}$ mile of the beach. High mountains rise immediately back of the coast.

San Marte bay.-Between San Marcial point and a steep, rocky bluff, $1 \frac{3}{4}$ miles south of it, is the small bay of San Marte, formed by a slight indentation in the coast line. Vessels may find anchorage here in good weather, in from 10 to 12 fathoms, within $\frac{1}{3}$ mile of the small sand beach at the bottom of the bay. The land back of the bay is extremely mountainous.

Reef.-Southeastward from San Marcial point; the innermost rock, $\frac{1}{4}$ mile distant from it, is a dangerous reef of rocks awash, on which the sea breaks at all weathers. It extends about $\frac{1}{3}$ mile in a general ESE. and 
WNW. direction, with deep water close to. Between the reef and the point 9 and 10 fathoms were found and $\frac{1}{4}$ mile outside the reef 30 fathoms.

San Marcial point is a moderately high, rocky cliff, surmounted by a peak 1,131 feet high.

San Marcial rock lies $1 \frac{1}{4}$ miles N. $16^{\circ}$ E. (N. $6^{\circ}$ E. mag.) from the point. It is of small extent and 25 feet high, with numerous smaller rocks surrounding it, and a small rock awash lying about $\frac{1}{4}$ mile $N N W$. from it.

Between San Marcial rock and the nearest point of the mainland there is a passage $\frac{3}{4}$ mile wide, with from 4 to 8 fathoms water.

Agua Verde bay.-From San Marcial point the coast trends nearly north $\frac{1}{2}$ mile and then turns abruptly to the westward. A mile and a half from where the coast turns to the westward is the small bay of Agua Verde, where there is good anchorage in ordinary weather, and fresh water may be obtained from a ranch near the beack. The best landing place is in the eastern part of the bay, near a bluff point, off the NE. side of which, close to, are one or two rocks arvash at low water.

San Pasquel point, at the western limit of Agua Verde bay, is a rocky bluff with a large white rock (Solitaria) lying 200 yards to the northeastward of it. A scant mile to the westward of San Pasquel point is another rocky bluff point, off which to the $\mathrm{NW}$. are two rocks above water. West of this last point is a stretch of sand beach about 2 miles in extent, on which are some ranches and an arroyo. Three-quarters of a mile west of this point the coast line assumes a northwesterly direction.

San Cosme point is a rocky cliff, rising abruptly to a hill 225 feet high. About a mile to the northward of the point is a group of rocks, the westernmost and highest of which, San Cosme rock, is 75 feet high. A third of a mile eastward of this is San Damien rock, 45 feet high, and at about onethird of the distance between the latter and the point are some low rocks, from 2 to 4 feet above water, with some rocks awash near them. The soundings obtained between these rocks and the shore showed no bottom at 10 fathoms. Four miles to the southwestward of San Cosme point is a conspicuous, sharp, twin peak, 3,808 feet high, which is an excellent landinark.

Coast.-From San Cosme point to Candeleros point, a distance of $10 \frac{3}{4}$ miles, the coast trends about NNW., and is a succession of bluffs and sand beaches; the mountains immediately back of it rise to a height of 2,000 feet.

White rock, which is 127 feet high and is surrounded by a number of smaller ones, both above and below water, lies 4 miles S. $40^{\circ}$ E. (S. $51^{\circ}$ E. mag.) from Candeleros point, and about 2 miles from the nearest shore. There is a good depth of water on all sides of these rocks, at a short distance from them. 
Monserrate, like all the other islands in this vicinity, is of volcanic origin and perfectly barren. It is 4 miles long in a north and south direction, and from one to two miles wide; its highest peak is 734 feet high. The south point of the island bears N. $48^{\circ}$ E. (N. $37^{\circ}$ E. mag.) from San Cosme point, which is the nearest point of the mainland, the channel between them being 7 miles wide, with from 50 to 80 fathoms of water. The southern and eastern shores of the island are a succession of bold, rocky bluffs, off' which in several places are projecting rocky ledges, under water, extending from an $\frac{1}{8}$ to $\frac{1}{4}$ mile off shore. Off the north and NE. points there are some outlying rocks, and on the north side there is a small bight, witl a short strip of sand beach near the northwestern point; the western side has a low, rocky shore with shelving points.

Las Galeras are two rocky islets lying $1 \frac{3}{4}$ miles to the northward of Monserrate. The easternmost is the larger of the two, and is 70 feet high. A reef of rocks extends off from it to the SE. nearly $\frac{1}{2}$ mile. The western islet is about 40 feet high. Between the two is a passage about $\frac{1}{8}$ mile wide, full of rocky ledges, and with varying depths of water. The least water found between Las Galeras and the north end of Monserrate was 7 fathoms.

One and a quarter miles north of Las Galeras there is a dangerous rock, which is only about a foot above high water. The soundings between it and Las Galeras show from 11 to 22 fathoms.

Santa Catalina lies $11 \frac{3}{4}$ miles to the eastward of Monserrate. It is $7 \frac{1}{2}$ miles long, north and south, and about 2 miles wide; its highest peak is 1,543 feet high. No detailed examination has been made of this island, but its shores are said to be abrupt, with deep water close to. There is reported to be a landing place on a sandy beach at its southern end. No soundings were obtained in the channel between it and Monserrate.

Candeleros point is a prominent steep bluff, about 50 feet high, the land back of it rising abruptly. The water is deep close up to the point; 95 fathoms, muddy bottom, were found within $\frac{1}{2}$ mile of it.

Los Candeleros are three pinnacle-shaped rocks, lying to the northward of the point and between it and Danzante island. The one nearest to the point ( $\frac{1}{2}$ mile distant) is about 100 feet high; the second, lying $\frac{3}{10}$ mile north of the first, is 80 feet high; and the third, $\frac{3}{4}$ mile NW. of the second, and about the same distance from the south point of Danzante island, is 40 feet high, and has some outlying rocks on its SE.

Caution.-The soundings between Candeleros point and Danzante island vary from 12 to 26 fathoms, and the passage should be used with great caution, as it is thought there may be other rocks in it that have not yet been discovered.

Coast.-From Candeleros point the coast makes a sweep to the westward, forming an open bay between it and punta Coyote, in which are several outlying rocks. The soundings along the shore of the bay are 
irregular; in some places only $2 \frac{1}{2}$ fathoms were found at $\frac{1}{2}$ mile distant from it. Back of the coast the land rises gradually to high mountains, the southern portion of the Sierra de la Giganta.

Rocks.-Three and a half miles N. $51^{\circ}$ W. (N. $62^{\circ}$ W. mag.) from Candeleros point is a group of rocks, varying in height from 15 to 40 feet, the outermost of which is a mile off shore. Between these rocks there is a passage $1 \frac{1}{4}$ miles wide, with about 16 fathoms water, apparently free from dangers; between them and the mainland is foul ground, with from: 2 to 3 fathoms water.

Water.-Abuut $2 \frac{1}{2}$ miles to the southward of punta Coyote there is a strip of sand beach, behind which is a fertile green slope with a ranch at its foot. An abundance of good fresh water may be obtained here from. wells 10 to 15 feet deep.

Punta Coyote is a steep, bluff headland 75 feet high, the eastern extremity of a pear-shaped peninsula about $1 \frac{3}{4}$ miles long and $\frac{7}{8}$ mile wide at its southern end, on which is a hill 350 feet high. The northern part of the peninsula, where it joins the mainland, is a narrow neck of land on which are some low sand hills.

Puerto Escondido, or hidden port, is a perfectly landlocked and secure harbor for small vessels, in all weathers; the peninsula just mentioned forms its eastern and northern sides. The entrance, which is only about 75 feet wide, lies between the southern end of the peninsula and the mainland, and only 9 feet of water will be found on the bar at high tide; inside the bar the water deepens to 4 and 7 fathoms. It is of small extent, being about a mile long north and south, and $\frac{1}{4}$ mile wide.

Danzante is a barren island lying a short distance off the coast between Candeleros and Coyote points, its southern end is $2 \frac{1}{2}$ miles distant from Caudeleros point, and $1 \frac{1}{2}$ miles distant from the nearest point of the mainland. It is $3 \frac{1}{2}$ miles long, $\frac{7}{8}$ mile wide in its widest part, and its highest peak is 450 feet high. On the SW. side there is a strip of sand beach off which anchorage may be found; with this exception, the shores of the island consist of bold, rocky bluffs from 25 to 75 feet high, with deep water close to. The northern end of the island for $\frac{1}{2}$ mile is detached from the main body by a shallow channel full of rocks, above and below water. Off the southern end is a detached pinnacle rock 25 feet high. Between Danzante and Carmen islands there is a channel $1 \frac{1}{2}$ to $2 \frac{1}{4}$ miles wide, free from all dangers, which is much used by vessels coming from the southward bound to Loreto. The tidal currents are very strong in this channel.

Chuenque bay.-At $1 \frac{3}{4}$ miles northwestward of punta Coyote, is a small bay known as Chuenque bay, which affords protection from all winds except northerly ones. On its eastern side is a small island, about $\frac{1}{2}$ mile long and 40 feet high. To enter Chuenque bay pass to the northward of 
this island, as the passage between its southern end and the mainland south of it is only 600 yards in width and quite shoal.

Nopolo point is a bold rocky point 75 feet high, situated about 5 miles to the northward of Chuenque bay. The intermediate coast consists of pebble beaches, and bluffs from 15 to 75 feet high, with deep water close to, 10 to 15 fathoms being found within 200 yards of the shore, deepening to 120 fathoms at a little more than $\frac{1}{2}$ mile distant.

Westward of Nopolo point there is a small shallow cove, open to the northward, which is sometimes used by small ressels.

From Nopolo point to the anchorage off Loreto, a distance of $5 \frac{1}{2}$ miles, the coast is a low sand beach, immediately behind which is a fertile country. A mile and a half south of Loreto is a low sandy point projecting lightly from the general coast line, know as Primera Agua point, off which shoal water (from one to 3 fathoms) extends about $\frac{1}{2}$ mile.

Loreto.-The mission was founded in 1697 , and the town was the ancient capital of the two Californias. It is situated at the entrance to a valley which extends inland to the high mountains of the Sierra de la Giganta. At the time of the Narragansett's visit it was a straggling village of adobe houses, mostly thatched with palm leaves, and containing about 150 inhabitants. The site was badly chosen, being on the bank of a water course, often dry for several years in succession, but which, after heavy rains in the mountains, is apt to become in two or three hours a raging torrent, sweeping everything before it. From time to time portions of the town have been destroyed or carried off by this stream, so that nearly all that now remains of the old, town is the mission church and its adjoining buildings. The church, a large stone structure with an arched roof and a dome at one end, is in pretty good repair. It contains some paintings and other ornaments worthy of notice; the altar and baptismal font are of pure alabaster.

Loreto, formerly the center of a considerable pearl trade, is the seaport of Comandu, with which it is connected by means of a road which passes over the Sierra de la Giganta; there is also a road to Mulege, about 70 miles up the coast.

Anchorage.-There is a good anchorage in ordinary weather off the town in 8 or 9 fathoms, $\frac{1}{2}$ mile from the beach; the best place to anchor is with the church and Sugarloaf peak in line. Immediately south of the mouth of the water course before mentioned, a sand spit with but 2 fathoms of water over it makes off nearly $\frac{1}{4}$ mile from the shore.

Supplies.-Fresh beef, wood, water, vegetables, and fruit may be obtained at Loreto. Near the town, to the northward, are several small lagoons, which are a favorite resort of wild ducks at certain seasons of the year.

Remarks.-There is no fruit or vegetable, either tropical or of the temperate zone, that can not be cultivated here; cabbages, cotton, lettuce, 
tobacco, wheat, corn, and onions were all seen growing together in the gardens, while the olive, date palm, orange, lemon, and banana are met with in abundance, and the vineyards produce a wine unequaled by any of those of Upper California. The palma-christi, or castor bean, is here a large tree with a woody trunk. Of the woods useful in the arts, the uña de gato, or cat's claw, is found here and at Mulege. It is a leguminous tree, the branches of which bristle with curved thorns resembling cat's claws; the wood is very firm and durable, taking as fine a polish as rosewood, and surpassing the latter in beauty.

Sierra de la Giganta, the highest peak of which is La Giganta, 5,974 feet high, lies back of this part of the coast. The road from Loreto to Comandu passes over the mountain range, winding by zigzags up to what appear from below to be inaccessible cliffs whence a slightly descending plain extends to Comandu. A copper mine at the foot of the mountains, known as El Sance, is said to be very rich, but it is not worked at present.

Comandu is an ancient mission and contains the ruins of a church that was doubtless a superior building. Many of the houses in the village are of cut stone ; the remainder, of bamboo, are covered with palm thatch. The population is variously estimated at from 500 to 1,000 . The valley in which Comandu is situated is about 6 miles long and rarely more than $\frac{1}{4}$ mile wide. It is very fertile, and most of it in a high state of cultivation, the principal products being panoche (the native sugar), wine, and fruits. A fine perennial stream of water flows through the valley, affording an abundant supply to the village.

At the head of the valley is a cañon cut in solid lava, 100 feet deep, with almost perpendicular sides.

Carmen island, which is irregular in its outlines, is 17 miles long in a general N.NE. and SSW. direction and $5 \frac{1}{2}$ miles wide in its northern portion, is of volcanic origion, and has a range of peaks, varying in height from 500 to 1,500 feet, extending through its entire length.

Punta Baja, the south end of Carmen island, is 5 miles distant from Candeleros point. Shoal water, with stony bottom, extends for more than $\frac{1}{4}$ mile off the point, which is a low spit of gravel. The land back of the point slopes gradually towards the hills and is covered with grass and low bushes.

Punta Arena is $2 \frac{2}{10}$ miles NW. of punta Baja, and is low sandy point, back of which are some sharp peaks from 600 to 900 feet high. The coast between the two points is a sand and gravel beach, with a few outlying rocks close to the shore, near punta Arena. There is deep water a short distance off the point and some huts on the beach near it.

Marquez bay.-Three miles to the northward of punta Arena, the intermediate coast consisting of steep, rocky bluffs and deep ravines, is a small 
bay, known as Marquez bay, at the head of which is a short sand beach, with some huts close to. North of Marquez bay the coast is generally steep and rocky, with moderately deep water close to. Off the point which forms the northern limit of the bay there are a few outlying rocks at a short distance from the shore.

Puerto Ballandra is a small bay situated $8 \frac{1}{2}$ miles to the northward of Marquez bay. It is about 800 yards in extent each way, with a depth of from 5 to $5 \frac{1}{2}$ fathoms in most parts. The entrance, which is scarcely 600 yards in width, is between high headlands. A small lagoon lies just back of the sand beach at the head of the bay.

Cholla islet.-A mile and three-quarters to the northward of puerto Ballandra there is a bluff point (the NW. end of the island), off which, at a distance of $\frac{1}{4}$ mile, there is a small low sand island about $\frac{1}{3}$ mile long and 20 feet high, known as Cholla islet. Off the northwestern end of the islet there are some outlying rocks.

Oto bay.-From the NW. point of the island the coast line turns sharply to the eastward, and at a distance of about $1 \frac{1}{4}$ miles curves again to the northward, forming an open bay known as Oto bay, in which vessels may anchor and find shelter from southerly winds. At the head of the bay there are a few deserted huts near an arroyo.

Tintorera point, which is $2 \frac{3}{4}$ miles from the NW. point of the island, is a steep bluff aboutt 80 feet high, off which are some outlying rocks.

About $1 \frac{1}{4}$ miles to the eastward of Tintorera point there is a small open bay, semicircular in shape, known as puerto de la Lancha, where anchorage may be had, with protection from southerly winds. The soundings in this bay show from $2 \frac{1}{2}$ to 7 fathoms water. The shores are, for the most part, gravel beaches.

A short distance eastward of puerto de la Lancha, at the mouth of an arroyo, is a small landlocked cove, $\frac{1}{4}$ mile long and 200 yards wide at the entrance, with from 3 to 5 fathoms of water; near its head are some deserted huts.

Lobos point, the northeastern extreme of the island, is a rocky headland 125 feet high, surrounded by detached rocks and connected with the body of the island by a low, narrow strip of land.

From Lobos point the coast turns abruptly to the southward, and for over 6 miles, to Perico point, is a succession of rocky bluffs with occasional detached rocks, the hills immediately back of the coast rising to heights varying from 400 to 700 feet.

Perico point, so named from its supposed resemblance to a parrot's beak, is a sharp, rocky cliff, surmounted by a peak of reddish color 460 feet high. A round detached rock 30 feet high lies very near the point, and 150 yards to the southward of the rock is another, below the surface of the water. 
At the top of a high cliff near Perico point there is a natural cave which is resorted to by the inhabitants of the village during the summer months.

Salinas bay.-From Perico point the coast turns to the northwestward and runs in that direction for about $2 \frac{1}{2}$ miles, when it turns to the westward and, gradually curving to the southward, forms Salinas bay, where good anchorage may be found in from 5 to 6 fathoms, protected from all winds except those from the SE.

Salt pond and village.-Near the head of Salinas bay, separated from the sea by a strip of shingle beach a little over $\frac{1}{4}$ mile wide and over which the sea never flows, is a salt pond or lake, about $1 \frac{1}{2}$ miles long and a mile wide, the water in which rises and falls with the tide, although there is no perceptible communication with the sea. The supply of salt (which is perfectly pure) from this pond seems inexhaustible, as what is taken away in one week, is reproduced in the next. The salt is precipitated in the form of pure crystals and has to be mined from the surface with crowbars, packed and shipped to San Francisco, where it is ground and sold without any purification as the finest table salt. The pond is connected with a landing place in Salinas bay by a railway. There is a small village situated on the shingle beach that intervenes between the salt pond and the head of the bay. A coast port and customhouse have been established, and the Carmen Islands Salt Company has built a fine wharf where vessels of 20 feet draft may load with facility and dispatch. The company has a small steamer for mail service between the island, La Paz, and Guaymas.

Port rules.-Vessels wishing to discharge foreign cargoes in a coast port must obtain permission at the nearest port of entry.

Vessels that wish to load at coast ports can clear for them from any port of entry. In either case the Treasury Department must be consulted and permission can only be given by this Department.

Water can be had at the wharf and is reasonable in price.

Fish and turtle abound in the bay.

Anchorage.-No pilots are required, and with the exception of an nccasional squall during August and September, the port is as secure as can be desired. The bottom is of sand over heavy mud, making the holding ground excellent.

White point, at the southwestern extremity of Salinas bay, is a steep, bluff point with a hill surmounting it; some outlying rocks extend off about 200 yards from it.

Gavelones point.-Two miles sonth of White point, the coast between being steep and rocky, is Gavelones point, back of which, bearing distant one mile, is a sharp peak, 1,491 feet high.

South of Gavelones point the coast recedes somewhat and consists for the most part of steep bluffs. About $2 \frac{1}{8}$ miles from the point there is a 
small stream where it is said fresh water may be procured; there is a short strip of sand beach on either side of the mouth of the stream. A mile and a quarter farther south is the mouth of an arroyo known as Arroyo Blanco.

Colorado point, which is a little over $1 \frac{1}{4}$ miles south of Arroyo Blanco, is a bluff point of moderate elevation and a reddish color. A sunken rock reported to lie off the point was carefully searched for, but could not be found; there are some detached rocks close to the point.

San Francisco bay.-South of Colorado point the coast recedes considerably, forming the open bay of San Francisco. After passing the point the bluffs become lower, finally terminating in a sand beach which extends to punta Baja. As punta Baja is approached shoal water makes off some distance from the land.

The coast north of Loreto is low and sandy for a distance of about 4 miles, affording good anchorage anywhere within $\frac{1}{2}$ mile of the beach in from 3 to 7 fathoms of water.

At Tierra Firma point a shoal with 3 fathoms water at its outer edge extends off about $\frac{1}{4}$ mile. Outside this shoal the soundings increase rapidly, 120 fathoms, rocky bottom, being found $1 \frac{1}{2}$ miles from the point. Three-quarters of a mile to the northward of Tierra Firma point low bluffs commence to take the place of the sand beach, and a mile farther on is a low bluff point, with an arroyo on its southern side.

Coronados island.-The nearest point of Coronados island lies $1 \frac{1}{2}$ miles to the eastward of the low bluff point just mentioned. The island is irregular in form, being about $1 \frac{3}{4}$ miles long, north and south, by $1 \frac{1}{2}$ miles wide at its widest part; near the northern end it attains a height of 928 feet. A low spit of sand and stones extends $\frac{3}{4}$ mile from its SW. side. Off the point of the spit there are some outlying rocks. With the exception of the sand spit just mentioned the shores of the island consist of steep rocky bluffs.

Passage.-Nearly in the center of the passage between Coronados and the mainland is a low islat surrounded by shoals, naking a passage 800 yards in width, with a least depth of $3 \frac{1}{2}$ fathoms; to pass through it is only necessary to keep in mid-channel. Between the islet and the SW. point of Coronados island there is a passage $\frac{1}{4}$ mile wide, with 4 and 5 fathoms, rocky bottom. These passages are not recommended for vessels. of any considerable size.

Anchorage.-To the northward of the low sand spit which makes off from the SW. side of Coronalos island is an excellent anchorage in which to ride out a southeaster.

Coast.-The coast north of Coronados island is generally bold and rocky, with the exception of the fertile valley and plain of San Bruno; the land immediately back of it rises to a height of from 1,500 to 2,000 feet. - The mouth of San Bruno creek lies 7 miles from the north point of Coronados island. The course of the creek being, for $1 \frac{1}{2}$ miles above its 
mouth, nearly parallel to the coast line, and behind a narrow strip of land on which are some high hills, it is somewhat difficult to recognize unless close in. The entrance is very narrow and shoal water extends off from it about $\frac{1}{4}$ mile.

Mangles point is a moderately high bluff, with a bold hill, 100 feet high, rising abruptly from it. The point is the southern end of a succession of cliffs of variegated color, varying in height from 200 to 300 feet.

Anchorage.-To the southward of Mangles point there is also a good anchorage with protection from northwesterly winds, in from 5 to 9 fathoms of water, a scant $\frac{1}{2}$ mile from the shore.

This anchorage is well known on the coast for the superior quality of wood that grows in the valleys near by ; it is said that fresh water also can be obtained here.

Caution.-In making for the anchorages care must be taken to avoid some rocks, the highest of which is only 2 feet above high water, that lie $2 \frac{1}{4}$ miles S. $16^{\circ}$ E. (S. $27^{\circ}$ E. mag.) from the point, and about a mile from the nearest land to the westward. Coming from the northward and intending to anchor, vessels may haul close around the point, as there is plenty of water and no hidden dangers.

Coast.-From Mangles point to Pulpito point, a distance of $14 \frac{1}{2}$ miles, the coast is generally steep to, with rocky bluffs and outlying rocks, the coast range of mountains rising immediately back. The shore line is very irregular, forming several prominent points, with intervening bays where anchorage may be found.

Mercenarios point, lying $4 \frac{1}{4}$ miles to the northward of Mangles point, is a rocky cliff of dark sandstone, surmounted by a red cone 519 feet high. Three-quarters of a mile northwestward of Mercenarios point is a short sandy point, with a jagged, rocky bluff 50 feet high at its end. Off this point, close to, are two small islets from 10 to 30 feet high, and $\frac{1}{4}$ mile east of it is a rock 6 feet above water. Between this rock and the shore $7 \frac{1}{2}$ fathoms of water were found.

The coast between the two points recedes a little and is a sandy beach, with an arroyo a little more than half way from Mercenarios point.

San Basilio point is a rocky cliff of red sandstone, about 50 feet high, surmounted by a hill 450 feet in height. There are a few outlying rocks near the point, with deep water close tothem.

San Juanico cove.-South of San Basilio point there is a small open bay called San Juanico cove, on the shores of which are some yellow bluffs and sand beaches; behind one of the latter there is a fine-looking valley, where, it is said, fresh water may be procured. In the northern and western parts of the bay there are a number of detached rocks, both above and below water. 
San Basilio bay.-Northward of San Basilio point the coast recedes considerably, forming the open bay of San Basilio, of which Gull rock, $2 \frac{1}{2}$ miles S. $21^{\circ} \mathrm{W}$. (S. $10^{\circ} \mathrm{W}$. mag.) of Pulpito point, may be considered the northern limit. The shores of the bay are low bluffs, alternating with sand and pebble beaches. Soundings a mile off shore gave no bottom at 15 fathoms.

Pulpito point, so called from its imagined resemblance to a pulpit, is a bold headland about 500 feet high, and, when first seen from the southward, appears like an island, the land connecting it with the coast range being low: There are some detached rocks, both above and below water, extending 200 yards off the point; outside of the rocks the water deepens suddenly to 15 and 20 fathoms.

Anchorage.- There is an excellent anchorage to the southward of the point, in from 5 to 10 fathoms of water, about $\frac{1}{4}$ mile from the beach, where a vessel will be well sheltered from the northwesterly winds. Along the western shore of the anchorage there are numerous outlying rocks, some of them over 300 yards off. In the northern bight there is a sand beach and good landing place. A remarkable triple-peaked mountain, 1,640 feet high, lies $3 \frac{7}{10}$ miles S. $51^{\circ} \mathrm{W}$. (S. $40^{\circ} \mathrm{W}$. mag.) from the highest part of Pulpito point, affording a good landmark.

Santa Antonita point, which is the southeastern limit of San Nicolas bay, is $1 \frac{1}{4}$ miles $\mathrm{NW}$. of Pulpito point. It is a low, rocky bluff, 15 feet feet high, with shoal water extending off it to the northward $\frac{1}{4}$ mile.

San Nicolas bay.-Northward of San Antonita point the coast falls away to the westward, forming the large open bay of San Nicolas. The southern shore of the bay is low, the lowland extending well into the interior; the western shore is bluffy, with outlying rocks and high land back of the coast.

Several arroyos open into the southwestern part of the bay, descending from a conspicuous table land 1,235 feet high, lying $2 \frac{1}{2}$ miles back of the coast. Seven and one-eighth miles N. $45^{\circ}$ W. (N. $56^{\circ}$ W. mag.) of Santa Antonita point is the entrance to a small cove in which launches may find shelter. An arroyo opens into the cove, and on either side of the entrance a short reef of rocks makes off.

Santa Teresa point is rocky, with a small sharp hill surmounting it and nany detached rocks lying off' it; southwestward from the point, at a distance of one mile, is a conspicuous peak 955 feet high.

Ildefonso island.-Off this part of the coast, its southern end bearing N. $6^{\circ}$ E. (N. $5^{\circ}$ W. mag.), distant $6 \frac{2}{10}$ miles from Pulpito point, lies the small island of Ildefonso. It is a barren rock a little more than a mile long NNW. and SSE., $\frac{1}{2}$ mile wide, and 387 feet high. A reef of rocks extends about $\frac{1}{4}$ mile off from its northern end. Soundings along the 
eastern shore show deep water close to, and between it and the mainland the water is deep, the passage being apparently free from danger.

Coast.-From Santa Teresa point to Concepcion point, a distance of over 19 miles, the coast has a general northwesterly trend, and is high, rocky, and precipitous, affording but little shelter from the prevailing winds. Patches of red water are frequently met with on this part of the coast.

Colorado point lies $4 \frac{1}{2}$ miles to the northwestward of Santa Teresa point, and is a high bluff of reddish color with many detached rocks lying • off it. The coast between it and Santa Teresa point forms several minor points with numerous detached rocks, both above and below water, lying off them.

San Lino bay is formed by a curve in the coast line south of Colorado point. It affords shelter from winds from west around by south to SE., but none from the $\mathrm{NW}$. winds; the soundings in the bay show from 4 to 8 fathoms.

At $3 \frac{1}{2}$ miles to the northwestward of Colorado point is a low point, with a gravel beach on either side off which a reef of rocks extends a little more than $\frac{1}{4}$ mile, with shoal water some distance outside of the reef. Five and a half miles westward from this point is a conspicuous mountain, of a whitish appearance, 2,434 feet high. Between the point just mentioned and Concepcion point, a distance of over 11 miles, there are several minor points with outlying rocks a short distance off them. Soundings taken along this part of the coast, a mile off shore, show from 20 to 40 fathoms of water.

Concepcion point is the northern extreme of the peninsula forming the eastern shore of Concepcion bay. It is an ill-defined bluff point about 30 feet high, with numerous rocks lying off it to the northward and westward.

From Concepcion point the coast trends to the southwestward about 2 miles, receding slightly to Aguja point, which, with San Domingo point, $\frac{4}{10}$ mile farther to the southwestward, forms the northeastern point of the entrance to Concepcion bay.

Aguja point is a sharp rocky bluff with some detached rocks and shoal water a short distance off it.

Concepcion bay, the entrance to which, between Aguja and Gallito points, is $3 \frac{1}{4}$ miles wide, extends over 22 miles in a southeasterly direction and varies in width from 2 to 5 miles. There are several small islands in its western part and a number of anchorages where vessels may lie sheltered from all winds.

The eastern shore of the bay is regular in its outline, consisting of sand and pebble beaches, back of which the land slopes gradually toward the mountain range in the interior of the peninsula that lies between the bay and the gulf of California. There are several low, projecting points, the 
most marked of which is San Ignacio point. Half a mile southeastward from San Ignacio point there is a ranch, near which is a small stream of fresh water. Except off Las Ornillas point, and for a short distance on either side of it, where deep water is found close up to the shore, shoals extend off the entire length of the eastern shore for distances varying from $\frac{1}{4}$ to $\frac{3}{4}$ mile.

La Pasajera.-The southern shore of the bay, known as La Pasajera, is like the eastern shore, low and sandy, the water shoaling gradually toward the beach. The road between Loreto and Mulege passes close along the southern shore and follows the general direction of the western shore of the bay, generally within a mile of the coast.

The western shore of the bay is very irregular in its outline, with many bluff points and intervening bights. Near the junction of the western with the southern shore of the bay there is a lagoon, at the entrance to which are some small islands and shoal water making off about $\frac{1}{2}$ mile. Near the western shore of the lagoon is a ranch and well.

La Tinaja point, about a mile to the northward of the entrance to the lagoon just mentioned, is famous for a well which supplies the best fresh water found near the shores of the bay. The well is situated just above the high-water mark, and is $2 \frac{1}{2}$ feet deep by 20 inches in diameter; the sides are of clay and gravel, and the bottom of rock. The water in the well rises and falls with the tide, but is quite fresh.

Frigoli point.-From La Tinaja point the coast line is nearly straight, and is low and sandy, with deep water close to the shore for a little over 3 miles, to Frigoli point, which is a sharp bluff point 40 feet high. After passing Frigoli point the coast becomes low and sandy again, with shoal water extending off nearly $\frac{1}{2}$ mile; near the point are several openings to an estero.

Ricason island lies $1 \frac{1}{2}$ miles in a northwesterly direction from Frigoli point. It is $\frac{1}{2}$ mile long $\mathrm{NW}$. and SE., about 200 yards in width, and 50 feet high. A narrow sand-spit, which is only partially covered at ordinary high tides, connects it with the mainland. To the westward of the island, on either side of the sand-spit, the water is shoal.

Ranada point.-Four-tenths of a mile west of Ricason island is a low bluff point at the foot of some hills, known as Ranada point. From this point the coast makes a sweep to the westward, forming a small bay, the shore of which is a sand beach. There is a ranch near the beach in the northern part of the bay, just south of which is the mouth of an estero. Fresh water of an inferior quality may be obtained near the estero. The coast for about 3 miles to the northwestward of the small bay just mentioned in a series of bluffs, with hills, from 100 to 300 feet high, back of them.

Coyote bay, which is about $3 \frac{1}{2}$ miles in extent north and south, and $1 \frac{1}{2}$ miles east and west, has a number of islets and rocks with surrounding 
shoals within its limits, making its navigation, especially in the northern part, somewhat difficult.

Bargo island is a barren rocky islet, 100 feet high, lying in the southern part of Coyote bay, 800 yards from the nearest land to the southward. In the passage between it and the mainland there is from 7 to 10 fathoms of water. There are some large outlying rocks to the westward of the island.

Guapa island lies $\frac{3}{4}$ mile directly east of Bargo island. It is 80 feet high and is surrounded by sunken rocks.

Rocks. - To the southward of the two islands just meutioned, about 1,200 yards distant from either, and 600 yards from the point at the southern limit of Coyote bay, is a solitary rock about 50 feet high.

In the northern part of Coyote bay there are several small islets surrounded by reefs and sunken rocks. They are generally from 30 to 40 feet in height, and in the channels between them, which are narrow and not thoroughly surveyed, the soundings show from 5 to 10 fathoms water

At the northern limit of Coyote bay is a point formed by a bold, rocky hill 200 feet high, connected with the mainland by a low, narrow strip of sand. Shoal water extends for some distance off this point in all directions.

San Pedro point is a bold headland, about 100 feet high, lying 3 miles to the northward of the point at the northern limit of Coyote bay. Shoals make off a considerable distance on either side of the point, and for a distance of about 2 miles north and south of it the navigable channel is not over $1 \frac{1}{4}$ miles wide. For about 2 miles to the northward of San Pedro point the shore is a low pebble beach, then come bluffs of a moderate height for about $1 \frac{1}{2}$ miles, succeeded by a sand beach that extends to within a mile of Gallito point.

Gallito point is a conically shaped rock connected with the mainland by a low strip of sand and surrounded by shoal water.

A sunken rock, with 3 fathoms of water over it, is reported as lying about a mile to the northeastward of Gallito point, and nearly on a line between Aguja and Sombrerito points. Diligent search was made for it without success, the soundings in the vicinity showing from 15 to 19 fathoms of water.

Equipalto rock.-From Gallito point the coast for $2 \frac{1}{4}$ miles, to Equipalto rock, is low and sandy. Equipalto rock, which is at the south side of the mouth of the rio Santa Rosalia, is similar in character to Gallito point. The land back of it is low and swampy, with several small lagoons. An extensive shoal which makes off from the mouth of the river extends along the shore to the sontheastward $1 \frac{1}{4}$ miles from Equipalto rock, its outer edge being full $\frac{3}{4}$ mile from the land throughout the entire distance.

Sombrerito point is a pyramidal-shaped rock 119 feet high, standing on a round pedestal, at the north side of the mouth of the rio Santa Rosalia. The land back of the point is low and sandy for a short distance. 
Colorado peak, 836 feet high and of a reddish color, lies about $1 \frac{1}{4}$ miles to the westward of Sombrerito point, and is an excellent landmark when making for Mulege anchorage.

Mulege anchorage is between Sombrerito and Prieta points. In standing in for the anchorage, as soon as Colorado peak is made out, steer for it, being careful not to get it on a bearing south of N. $84^{\circ} \mathrm{W}$. (S. $85^{\circ} \mathrm{W}$.), as there is much foul ground near the coast south of that line of bearing; anchor in from 5 to 7 fathoms, $\frac{1}{2}$ mile from the beach.

Mulege was formerly the mission of Santa Rosalia de Moleje, and is situated on the bank of a fresh-water stream (rio Santa Rosalia), a little over 2 miles from its mouth. It is a small, straggling village, the inhabitants of which, variously estimated from 500 to 1,000 in number, are engaged principally in mining, pearl fishing, raising and exporting fruits. They are much more enterprising than the majority of the inhabitants of of the peninsula.

Supplies.-Wood, water, and excellent fresh beef may be procured at all times, as well as many varieties of vegetables and fruit in their season. Game is abundant in the mountains back of the village, and the wines of Mulege, resembling heavy port and claret, are famous.

Prieta point, just north of Mulege anchorage, is a low bluff of dark color, with shoal water extending off it a short distance to the northwestward.

Colorado point, which may be considered the southern limit of Santa Inez bay, is a mile to the northwestward of Prieta point, and is a reddish bluff of moderate height lying at the foot of a lateral spur of hills.

Santa Inez bay.- North of Colorado point the coast sweeps to the westward, forming the large open bay of Santa Inez, of which Santa Inez point is the northern limit. The shore of the bay is generally low and sandy, with low hills a short distance back. Near Santa Inez point there are some conspicuous barren table hills, the highest of which, known as Barracas table, is about 300 feet high. The soundings in the southern part of the bay show from 5 fathoms near the shore to 18 or 20 fathoms or over at about $1 \frac{1}{2}$ miles off; in the northern part the water is much shoaler; not more than 3 fathoms will be found at $\frac{3}{4}$ mile from the shore, deepening to 5 and 8 fathoms between the mainland and the Santa Inez islands.

Monument.-Five and a half miles N. $26^{\circ}$ W. (N. $37^{\circ}$ W. mag.) from Colorado point there is a monument standing on the beach, which marks the southern boundary of a track of land (Santa Magdalena plains), which has been acquired by a company organized in San Francisco for the purpose of founding a colony.

Santa Magdalena plains. - The plains of Santa Magdalena are several miles in width and extend along the coast to the northward. It is said that there is not a drop of fresh water to be found on them, and not an acre 
of land that can be cultivated, so thickly is the surface covered with rocks. It is hardly necessary to say that the proposed colony has never been established.

Mission of Guadelupe.-The old mission of Guadelupe was situated on the northern edge of Magdalena plain, at the mouth of San José cañon. The remains of an extensive aqueduct, constructed for irrigating purposes, are still to be seen there. The mission buildings are entirely destroyed.

Santa Inez point, sometimes called cape Barracas, is low and rocky, with a small hill surmounting it. Half a mile to the westward of the point, in the bay, are some outlying rocks.

Anchorage may be obtained under the lee of the point, sheltered from the northwesterly winds, in from 4 to 5 fathoms water, $\frac{1}{2}$ mile from the shore.

Santa Inez islands, three in number, lie to the southeastward of the point of the same name. They are surrounded by shoals and sunken rocks, but between them and the point there is a clear passage, through which from $4 \frac{1}{2}$ to 5 fathoms may be carried. The southernmost and largest of these islands is $\frac{7}{8}$ mile long, $\frac{1}{3}$ mile wide, and 30 feet high. Its southern point is low and rocky, with shoal water extending some distance off from it.

The northernmost of the islands is 15 feet high and small in extent; its center bears S. $69^{\circ}$ E. (S. $80^{\circ}$ E. mag.) from Santa Inez point, distant 2 miles.

Shoal.-Directly west of the southeasternmost island, its center about a mile distant from it, is a shoal $1 \frac{1}{4}$ miles long NNW. and SSE. and $\frac{1}{2}$ mile wide, with only 3 fathoms of water over it.

Eastward of this group of islands the water deepens quickly.

Chivato point is a low bluff, with many detached rocks lying off it, and table land from 40 to 60 feet high back of it. It lies $1 \frac{3}{4}$ miles to the northward of Santa Inez point, the intermediate coast being bluffy, with a few outlying rocks.

From Chivato point the coast falls away to the westward, its general trend as far as the entrance of San Lucas cove, a distance of $14 \frac{1}{2}$ miles, being WNW. The shore is generally low and sandy, with occasional bluffs; back of it the land slopes gradually to the mountains in the interior, which are upwards of 3,000 feet high.

San Marcos island lies off this part of the coast. It is a barren, extremely hilly island, about $5 \frac{1}{2}$ miles long in a general NNW. aud SSE. direction, varying in width from $1 \frac{1}{4}$ to $2 \frac{1}{2}$ miles. The highest peak, nearly in the center of the island, is 891 feet high.

The east face is for the most part composed of rocky bluffs, varying in height from 20 to 300 feet. Near the SE. extremity there is a strip of sand and gravel beach about a mile long, and there is a similar one, $\frac{3}{4}$ mile 
long, on the NE. face. Off this latter beach are a number of outlying rocks, and a rocky reef extends a short distance off from the easternmost point.

Off the north point, which is surmounted by a sharp hill, are three white islets, varying in height from 20 to 40 feet, and a number of detached rocks which extend northwarl nearly $\frac{1}{2}$ mile.

The NW. face is of steep bluffs, with many outlying rocks, of which the two most conspicuous are 25 and 40 feet high. From the western extremity of the island to the south point the coast is of sand beaches and bluffs from 15 to 20 feet high, the land sloping from the hills in the interior.

The south point of the island is a low sand-spit nearly $\frac{1}{2}$ mile long, from which a rocky shoal extends $1 \frac{1}{4}$ miles to the southward. Eastward of the low sand-spit the south coast of the island is a series of perpendicular bluffs about 30 feet high, with shoal water extending off nearly $\frac{1}{2}$ mile.

Anchorage.-There is good anchorage off the south end of the island, eastward of the low sand-spit, in from 5 to 7 fathoms of water.

Water.-Fresh water may be obtained near the northern end of the island.

Remarks.-There are extensive deposits of gypsum on the island. It is massive and crystalline (alabaster), in layers entirely exposed, from 25 to 50 feet thick. It could be worked with great facility and woukl probably yield large profits. Pumice stone is found in several localities, and one of the hills is said to be composed entirely of talc. In the waters surrounding the island are several beds of the pearl oyster.

Lobos rock, which is about $\frac{1}{4}$ mile long NNW. and SSE., and 20 teet high, lies $\frac{1}{2}$ mile S. $38^{\circ}$ E. (S. $49^{\circ}$ E. mag.) from the scuthr: j" int of San Marcos island. Numerous sunken rocks surround it, am net cyer $1 \frac{1}{2}$ fathoms can be carried through the passage between it and Sun MI:Lce.

Craig channel separates San Marcos island from the mainland. It is a little over a mile wide in its narrowest part and 4 fathoms of water may be carried through it. In using it care must be taken to avoid the shoal that makes off from the south point of San Marcos island, which has 3 fathoms on its southern edge, quickly shoaling to 2 and one fathom.

San Lucas cove is a safe anchorage in all weathers for boats or small craft drawing less than 6 feet of water. It is about 2 miles in extent, north and south, and from $\frac{1}{2}$ to $\frac{3}{4}$ mile wide. The entrance is narrow and shoal, with a small sand island nearly in the center. The channel is on the north side of the island, and has from one to $1 \frac{1}{2}$ fathoms of water in it at low tide; inside the cove the depth of water varies from half a fathom to a fathom.

Coast.-From the entrance to San Lucas cove the coast trends northerly and is low and sandy for 3 miles to a prominent point surmounted by a 
red mound 60 feet high. Thence to Santa Maria cove, a distance of $12 \frac{1}{2}$ miles, the coast is a succession of bluffs of moderate height, with intervening sand beaches. The land back rises gradually to a high range of mountains in the interior. Las Tres Virgenes, over 6,000 feet high, are plainly visible to the northwestward. The soundings along this part of the coast show, with one or two exceptions, deep water close to the shore, from 20 to 40 fathoms being found a mile off.

Santa Agueda point is 5 miles to the northwestward of the point at the foot of the red mound before mentioned, and is the eastern point of entrance to a lagoon and cañon of the same name. It is low and sandy, with a shoal extending $\frac{1}{2}$ mile off it and across the entrance to the lagoon; outside the shoal the water deepens quickly, 60 fathoms being found $\frac{1}{2}$ mile off: A short distance north of the point is a large rock 15 feet high.

Six Cañons.-Cañon de Santa Agueda is the southernmost of six similar valleys or cañons between Santa Agueda point and Santa Maria cove. They are widely known for their yield of rich copper ore, which comes from some distance in the interior. The mines were being worked at the time of the Narragansett's visit, and during that year 18 ships were loaded with the ore, principally for European markets. The ore is mostly from the surface and in the form of malachite.

At cañon de Providencia and cañon de Purgatorio are landing piers, and a short distance to the nurthward of cañon de Santa Rosalia is a ranch close to the beach.

Caution.-In anchoring off these cañons the lead.must be kept constantly going, as the water is deep to within $\frac{1}{4}$ mile of the shore and then shoals suddenly.

Santa Maria cove lies 3 miles to the northward of cañon de Santa Rosalia. It is about $\frac{3}{4}$ mile wide and $\frac{1}{4}$ mile deep ; the southern shore is rocky, with bluffs and low hills back of it; on the north side the land is hilly, ending in a sharp, bluff point, with numerous outlying rocks off it ; at the head of the cove is a shingle and sand beach. Santa Maria cañon opens into the cove.

Anchorage may be had in Santa Maria cove, about $\frac{1}{4}$ mile from the beach, in 5 or 6 fathoms of water, with shelter from NW. winds, but open to southeasters.

Tortuga island lies 23 miles nearly due east of Santa Maria cove, its highest peak bearing N. $48^{\circ}$ E. (N. $37^{\circ}$ E.) from the north end of San Marcos island, distant $15 \frac{1}{2}$ miles. It is mountainous and barren, about 2 miles long ESE. and WNW. by a mile in width at the center, narrowing towards the ends. The highest peak, near the southern shore, is 1,016 feet high.

Coast.-From the northern limit of Santa Maria cove the coast first trends nearly north for $3 \frac{1}{2}$ miles, and then gradually falls away to the 
northwestward for 3 miles farther, to Cape Virgenes. The land comes down to the coast in steep slopes from Santa Maria mountain, which is about $3 \frac{1}{2}$ miles inland and 4,424 feet high, its ridge running parallel to the coast for several miles. The shore is of broken bluffs, varying in height from 30 to 200 feet, with occasional gravel beaches and deep arroyos.

The depth of water off this part of the coast is very great, soundings within $1 \frac{1}{4}$ miles of the shore showing no bottom at 300 fathoms.

Las Tres Virgenes.-From 12 to 14 miles inland are three remarkable mountains lying nearly parallel to this part of the coast, known as Las Tres Virgenes, the highest of which reaches an altitude of 6,547 feet. They are the northeastern end of a continuous belt of volcanic peaks extending toward San Ignacio.

Sulphur is said to be found in abundance in the vicinity of these volcanoes.

Cape Virgenes is a rocky cliff about 200 feet high, surmounted by a hill 600 feet high, the high coast range lying a short distance inland. Soundings off the point gave 5 fathoms close to, deepening rapidly to 130 fathoms a mile off. Northwestward of cape Virgenes the coast is generally low, the mountain range being several miles in the interior.

Punta Baja, which is $4 \frac{1}{2}$ miles from cape Virgenes, is of shingle, with a shoal extending off a short distance. Just sơuth of this point is the mouth of a cañon which leads up to a silver mine, known as Reforma. About $\frac{3}{4}$ mile to the southeastward of the point is a landing place, marked by a flagstaff with a white flag.

Santa Ana point, $7 \frac{1}{4}$ miles farther up the coast, is steep, with hills 400 feet high immediately back of it. It forms the eastern limit of Santa Ana bay, which is about $3 \frac{1}{2}$ miles wide and from $\frac{1}{4}$ to $\frac{3}{4}$ miles deep. The southern and western shores of the bay consist of sand and shingle beaches, the lowland back of them sloping gradually to the mountains. The water is very deep to within a short distance of the shore.

Anchorage may be had, with shelter from southeasters. The western limit of the bay is a low shingle point, off which a shoal extends for over $\frac{1}{4}$ mile. On the point is the opening to a small lagoon, into which Santa Ana creek flows. This fresh-water creek may be recognized by the grass and trees on its banks.

Two and three-quarter miles northwestward is another low point and opening to a lagoon, with a shoal surrounding it.

Trinidad point is 7 miles from the point last mentioned; the intermediate coast assumes a more northerly trend and is generally bluff. There are several outlying rocks off this part of the coast, and a range of hills rises immediately back of it. The point itself is a prominent headland 250 feet high, surmounted by moderately high bluffs; several detached rocks lie off it. 
San Carlos bay is an open bay formed by the falling away of the coast line to the northward of Trinidad point. About $1 \frac{3}{4}$ miles to the northward of the point is a small, rocky islet of whitish color, the highest part of which is 6 feet above high water; shoal water is found a short distance off it on all sides. Betiveen the islet and Trinidad point is a sandy bight, with shoal water extending nearly $\frac{1}{2}$ mile off shore.

Three and three-quarters miles N. $25^{\circ} \mathrm{W}$. (N. $36^{\circ} \mathrm{W}$. mag.) from the islet just mentioned is a rocky point surrounded by numerous detached outlying rocks, one of which, nearly $\frac{3}{4}$ mile north of the point and $\frac{1}{2}$ mile from the nearest shore, is $\frac{1}{4}$ mile long and 6 feet high.

San Carlos point is low, composed of sand and shingle, and may be recognized by a peak about 5,000 feet high, known as Sharp peak, which lies $9 \frac{1}{2}$ miles nearly west from it.

Red water.-Along this part of the coast extensive patches of the red water before mentioned were met with. Soundings made while steaming through them gave no bottom at 55 fathoms.

Coast.-From San Carlos point to cape San Miguel, a distance of 12 miles, the general direction of the coast line is nearly north. The coast is for the most part low, with sand and gravel beaches and an occasional low bluff, until within about $2 \frac{1}{2}$ miles of cape San Miguel, whence to the cape the shore line is an almost continuous bluff about 50 feet high. Back of the coast the land slopes gradually to the hills and is covered with low bushes and cactus.

San Juan Bautista point, lies $4 \frac{3}{4}$ miles to the northward of San Carlos point. It is low and composed of sand and gravel. Shoal water extends. off it $\frac{1}{4}$ mile.

Between the two points the coast recedes about a mile, forming the open bay of San Juan Bautista, the soundings in which are very regular.

A little to the northward of San Juan Bautista point the hills approach the coast, ending in bluffs.

Cape San Miguel is a bold, rocky bluff, 150 feet high, with several outlying rocks a short distance to the eastward of it. Back of it, not over 5 miles distant, is a group of conspicuous mountains, varying in height from 2,000 to 3,500 feet.

Anchorage, sheltered from the NW. winds, may be found just south of the cape, in 7 or 8 fathoms of water, $\frac{1}{2}$ mile from the shore.

A mile south of the cape is the northern end of a shoal that extends nearly 2 miles along the shore to the southward, and has only $2 \frac{1}{4}$ fathoms of water on its outer edge, which is from $\frac{1}{4}$ to $\frac{1}{2}$ mile off shore.

Coast.-From cape San Miguel to Santa Teresa point, a distance of $13 \frac{1}{2}$ miles, the coast is generally low, being formed of alternate sand beaches and low bluffs, the coast range lying a short distance inland. 
Just north of cape San Miguel the coast sweeps to the westward, forming an open bay.

Santa Teresa point is a rocky bluff about 30 feet high, the land back of it rising abruptly to a height of 567 feet. South of the point is the small open bay of the same name. At the bottom of the bay there is a sand beach, with low land back of it, extending to San Francisquito bay. In the southern part the shore consists of rocky bluffs, with hills about 150 feet high rising immediately back of them and some outlying rocks fronting them.

Good anchorage, sheltered from the NW. winds, may be found about $\frac{1}{4}$ mile from the beach in 8 or 9 fathoms of water, the point bearing N. $28^{\circ}$ E. (N. $16^{\circ}$ E. mag.), distant from 600 to 800 yards.

On the low neck of land between Santa Teresa and San Francisquito bays is an extensive bed of a fresh-water pond, which is dry during 8 months of the year.

A prominent sharp peak, 6,258 feet high, lies 32 miles nearly due west from Santa Teresa point, and is plainly visible when off the coast in this vicinity.

San Pedro Martir island lies off this part of the coast and nearly midway in the gulf. It is a barren, triangular rock, less than a mile in extent either way, its highest point having an altitude of 1,052 feet. Off it southern face are several detached rocks, some of them $\frac{1}{2}$ mile from the shore.

Coast.-Northward of Santa Teresa point, and intervening between it and San Francisquito bay, is a prominent headland, having a rugged, bluff coast, with barren hills from 300 to 500 feet high back of it.

San Gabriel point lies $1 \frac{2}{10}$ miles north of Santa Teresa point, and is a rocky bluff 45 feet high, with high volcanic hills just back of it and numerous detached rocks surrounding it. Just west of the point is a strip of sand beach $\frac{1}{4}$ mile long, and adjoining the western end of the sand beach is a rocky point similar in character to San Gabriel point.

San Francisquita bay.-The point just mentioned is the eastern point of the entrance to San Francisquito bay, which is about a mile in width between the heads at the entrance and the same in depth from a line drawn between them. It is open to the north and NE., but affords good shelter from either NW. or SE. winds, which are the prevailing ones in the gulf.

A small cove opens into the southern part of the bay. The water in the cove is shoal and the entrance narrow, being between two rocky points 300 yards apart with numerous outlying rocks off them, uarrowing the passage to about 100 yards.

The country in the vicinity of the bay is extremely barren and stony. 
Anchorage.-The best anchorage is in the SW. part of the bay in from 5 to 6 fathoms of water, and about $\frac{1}{4}$ mile off a sand beach $\frac{1}{2}$ mile long and flanked on either side by rocky bluffs.

Coast.-From the NW. point of the entrance to San Francisquito bay to San Francisquito point, a distance of 2 miles, the coast consists for the most part of steep rocky bluffs, with table land from 300 to 400 feet high immediately back of them.

San Francisquita point is a low, rocky bluff, with a number of detached rocks lying off it, close to. A short distance west of the point there is said to be a place at the foot of the hills where fresh water may be found.

Sal si puedes channel, which lies between the mainland on the west and the islands of San Lorenzo, Sal si puedes, Raza, and Partida on the east, is. a wide, deep channel through which the current sets strongly, especially with an ebb tide and a northwesterly wind, against which sailing vessels. find it almost impossible to make any headway.

Owing to the great depth of water in most parts of the channel there are few places where a vessel may anchor, but anchorage may be found near the western shore and also in the vicinity of the islands Raza and Partida.

San Lorenzo island is the southernmost and largest of the islands forming the eastern side of Sal si puedes channel. It is $12 \frac{1}{4}$ miles in length and between one and 2 miles wide.

Like most of the islands in the gulf it is of volcanic origin, high and barren. The highest peak, near the southern end, has an elevation of 1,592 feet.

Three miles from the northwestern end of the island is a narrow boat passage, really making two distinct islands.

Landing.-Three miles to the southeastward of the boat passage, on the channel side of the island, is a slightly projecting sand beach where a landing may be effected in smooth weather, and at the extreme SE. of the island is another small strip of sand beach which, with the prevailing northwesterly winds, affords a good landing place.

With the exception of the above-mentioned sand beaches the shores are bold, rocky bluffs predominating.

Rock.-About $1 \frac{1}{4}$ miles nearly due east of the northwestern point of the island, and 300 yards from the nearest shore, is a detached white rock 20 feet high.

Sal si puedes island, lying a mile to the northwestward of San Lorenzo, is about $1 \frac{1}{2}$ miles long SE. and NW., with a greatest width of $\frac{1}{2}$ mile. The highest peak, near the southern end, is 376 feet high. Several detached rocks lie off the island, one of which, near the northwestern end, is 50 feet high. 
Rock.-Nearly midway between Sal si puedes and San Lorenzo islands, a little nearer the former, is a rock awash, and it is probable that there are other hidden dangers in the passage, which has not been examined, and its use is not recommended.

Isla Raza lies $4 \frac{3}{4}$ miles north of the $\mathrm{N} W$. point of Sal si puedes. It is about $\frac{3}{4}$ mile long east and west, $\frac{1}{2}$ mile wide, and about 100 feet high, presenting a whitish appearance from the deposit of guano on it. Its shores consist for the most part of moderately high bluffs, with outlying rocks close to.

Anchorage in from 5 to 8 fathoms, gravel and rocky bottom, will be found on the south side of the island, about 600 yards distant from the shore. There is a landing pier, house, and flagstaff on the island abreast of the anchorage. A reef of rocks extends a short distance off from the southeastern end of the island, and vessels anchoring should be careful to give it a good berth.

Raza rock is a small white rock 75 feet high, lying a little over a mile N. $53^{\circ}$ W. (N. $65^{\circ}$ W. mag.) from the NW. point of Raza island. There is deep water, free from dangers, on all sides of it except the SW., where at a distance of 400 yards is a rock awash, with 20 fathoms of water close to.

Remarks.-The tidal currents in the vicinity of these islands are very strong, occasionally causing heavy tide rips. Northwesterly winds frequently blow with great violence for two or three days at a time.

Isla Partida, so called from its appearing, when seen from a distance, like two islands, is $4 \frac{1}{2}$ miles N. $42^{\circ} \mathrm{W}$. (N. $54^{\circ} \mathrm{W}$. mag.) from Raza island. It is about $1 \frac{1}{4}$ miles long, $\frac{1}{2}$ mile wide, and has two peaks, each 400 feet high, joined by a low, narrow strip of land.

On the western side of the island is a small cove or bight, open to the northward, in which there are from 3 to 8 fathoms of water. A rock 85 feet high lies off the steep bluff point which forms the western side of the bight.

Off the eastern side of the island, about $\frac{1}{3}$ mile distant from it, is a small islet 75 feet high. Between this islet and Isla Partida, anchorage may be found in from 5 to 20 fathoms, with shelter from the northwesterly winds.

White rock.-Six-tenths of a mile to the northward of Isla Partida is a rock 175 feet high called White rock, from which a reef makes off to the northward about $\frac{1}{3}$ mile, ending in a rock 2 feet above water at low tide. The soundings are irregular, with rocky bottom, for about $1 \frac{1}{4}$ miles farther north, whence they increase rapidly.

San Esteban island. See page 99.

Coast.-From San Francisquito point the coast sweeps to the westward for about 10 miles, and then again assumes a northerly direction as far as Las Animas point. 
San Rafael bay is an open bay formed by the receding of the coast line north of San Francisquito point, and affords good protection from southerly winds. Its shores consist for the most part of sand beaches, with occasional low bluffs. The land slopes gradually from the interior, with numerous ravines, and is covered with vegetation. Soundings in the southern part of the bay gave 40 fathoms at a mile distant from the shore, while in the northern and western portions, at the same distance off, from 10 to 20 fathoms were found.

From the northwestern limit of San Rafael bay to Las Animas point the coast consists of rocky bluffs, with mountains rising immediately back of it.

Seven miles to the southward of Las Animas point is a conspicuous group of peaks over 3,000 feet high.

Barnabé rocks, two in number, lie $3 \frac{1}{2}$ miles to the southeastward of Las Animas point, and from 600 to 800 yards off a low, slightly projecting point. They are only 2 feet above water, and between them and the shore there is a shallow passage with a rocky bottom, fit only for boats.

Anchorage.-There is a fair anchorage southward of the rocks in 7 or 8 fathoms of water, coarse, sandy bottom, about $\frac{1}{4}$ mile from the beach.

Las Animas point is a bold rocky bluff, from 75 to 125 feet high, with several detached rocks close to. Back of it steep hills of a reddish color rise abruptly to heights varying from 300 to 500 feet, with mountains over 2,000 feet high a short distance inland. The water off the point is very. bold, 60 fathoms being found within less than $\frac{1}{2}$ mile. This point forms the southwestern point of entrance to Ballenas channel.

Ballenas channel, which lies between the mainland and Angel de la Guardia island, is about 45 miles long, varying in width from 8 to 15 miles. The northwesterly winds sometimes blow through the channel with great force, raising a heavy sea, against which a vessel can make but little headway. The tidal currents are very strong at times. A current of 3 knots was experienced by the Narragansett.

Soundings obtained within less than a mile from the shore of Angel de la Guardia gave 205 fathoms, and the water the water throughout the channel is believed to be very deep.

Las Animas bay.-From Las Animas point the coast turns suddenly to the southwestward and maintains that general direction for a distance of $5 \frac{1}{2}$ miles, to the mouth of a small lagoon, whence it sweeps around to a point (not named) bearing N. $69^{\circ} \mathrm{W} .\left(\mathrm{N} .81^{\circ} \mathrm{W}\right.$. mag.), $6 \frac{1}{4}$ miles distant from Las Animas point, forming a bay of considerable extent, known as Las Animas bay, where good anchorage may be had, with protection from either of the prevailing winds. 
The shores of the bay consist for the most part of sand beaches, with a few bluffs on that part lying between Las Animas point and the entrance to the lagoon before mentioned.

About 2 miles northwestward from the lagoon entrance is a steep, bluff point, surmounted by a brownish-colored mound 80 feet high. Off this point are several islets, varying in height from 30 to 75 feet.

The best anchorage is in the southern part of the bay, in from 6 to 12 fathoms of water, nearly on a line between the above-mentioned point or islets and the lagoon entrance, taking care not to approach the latter within $\frac{3}{4}$ mile.

The point at the northwestern limit of the bay is a sharp, rocky bluft from 25 to 40 feet high, surmounted by a dark hill 100 feet high, the mountains bacis of it rising abruptly to a height of 3,000 feet and upwards.

Off the point in a northerly direction, about $\frac{1}{2}$ mile distant and connected with it by a rocky shoal, is a low islet, only 2 feet above high water.

About $1 \frac{1}{2}$ miles N. $21^{\circ} \mathrm{W}$. (N. $33^{\circ} \mathrm{W}$. mag.) from the point just mentioned is another prominent, sharp, bluff point (not named), formed by a spur of reddish hills from 200 to 300 feet high. The coast between the two points forms a bight a mile deep, with a sand beach at the bottom.

Rocky island, which lies $1 \frac{1}{2}$ miles farther up the coast, is a barren rock 75 feet high, lying $\frac{1}{2}$ mile off shore, with a 3 -fathom passage between it and the beach, which is of sand.

From here to the entrance to Angeles bay the coast is a succession of sharp, rocky points, with outlying rocks close to, the land back rising abruptly to a height of over 3,000 feet.

Angeles bay is a fine sheet of water, which covers an area of about 25 miles. It is almost completely landlocked, having for its protection on the east and NE. no less than fifteen islands and islets. The shores of the bay are for the most part sand beaches, with one or two rocky bluffs. In the southern part, shoal water extends off some distance from the shore.

There are several safe passages into the bay. The southernmost is between Red point (which is a reddish colored, rocky bluff) and two small islands, 50 and 70 feet high, which lie about 600 yards to the northward of it. This channel is believed to be entirely free from hidden dangers and has a depth of water varying from 20 to 30 fathoms. Another passage, which is considered perfectly safe, lies to the northward of the two islands just mentioned, between them and a larger island of a dark reddish color, on the southern face of which is a hill 225 feet high, with a stone monument on it. This channel is $\frac{1}{2}$ mile wide and has from 20 to 30 fathoms of water through its center. Northward of the last-mentioned island is another passage, which is not recommended and is marked "dangerous" on the charts of the United States Hydrographic Office. .It contains many sunken rocks and rocks awash, with deep water close to them. 
On the other side of this passage is a group of islands, varying in height from 90 to 125 feet, with deep waters and no dangers between them and the mainland. The northern passage lies between Smiths island (which is the northernmost and largest of the islands lying off the entrance to Angeles bay) and a long narrow neck of land that makes off in a southeasterly direction from the mainland and is terminated by a rocky bluff. When up with this bluff, the passage lies between it and the group of islands before mentioned. The northern passage is over a mile in width and free from dangers, except at a point about midway of the length of Smiths island, where some dangerous rocks, lying $\frac{3}{4}$ mile from the island, nanrow the channel to $\frac{9}{10}$ mile. Over 10 fathoms water can be carried through it.

Neither of these passages should be attempted, unless in an emergency, when the land can not be plainly distinguished, as that is the only guide for using them.

Supplies.-Water can be obtained from springs near the anchorage, at the foot of the round-topped mountain; their situation is marked by a growth of weeds and bushes. The bay abounds in fish and turtle, and good oysters can be gathered along the rocky shores. Banks of pearl oysters are also reported to exist. The country in the vicinity is said to be rich in copper ores, sulphur, and argentiferous lead. In the northern part of the bay is a deep bight, formed by a narrow neck of land that projects $3 \frac{1}{4}$ miles in a southeasterly direction from the mainland. This bight has not been examined.

Directions.-When coming from the southward it is best to follow the coast, using the southernmost passage (that between Red point and the two small islands). Keep in mid-channel until past Red point, then steer $\mathrm{N}$. $78^{\circ} \mathrm{W}$. (west mag.) for the best anchorage, which is at the mouth of a small cove formed by a low sand spit which projects over $\frac{1}{2}$ mile from the mainland in a southerly direction. In standing in for the southernmost passage, bring a conspicuous mountain, 3,423 feet high, called Round Top, which is 2 miles from the western shore of the bay, to bear $\mathrm{S} .71^{\circ} \mathrm{W}$. (S. $59^{\circ}$ (west mag.) and steer for it, keeping it on that bearing until nearly up with Red point, when keep in mid-channel until past the point.

Coming from the northward and intending to anchor in Angeles bay, follow the coast, passing between it and Smiths island and keeping well over toward the high bluffs at the southeastern end of the narrow neck of land before mentioned, to avoid the dangerous rocks lying $\frac{3}{4}$ mile to the westward of Smiths island. Upon arriving off the extremity of the narrow neck, steer S. $23^{\circ}$ W. (S. $11^{\circ}$ W. mag.), passing between it and the group of islands to the southward. When inside the islands follow the coast line, taking care to keep rather nearer the islands than the mainland, and at least a mile from the latter, to avoid a shoal that makes off from it; $11562-6$ 
there are no hidden dangers outlying from the islands. When the point of the low sand spit, which forms the cove before mentioned, bears N. $78^{\circ}$ W. (west mag.) haul up for the anchorage.

'To pass through the channel to the northward of the two islands which form the north side of the southernmost passage, it is only necessary to keep a reasonable distance off the land on either side.

Smiths island is high and flat topped, nearly 4 miles long, from $\frac{1}{4}$ to over $\frac{3}{4}$ mile wide, and at its northwestern extreme 1,554 feet high. An islet 60 feet high lies off its northwestern point, separated from it by a narrow boat channel. Off its western face, about midivay of its length and connected with it by a rocky shoal, lies an islet 75 feet high, about $\frac{1}{2}$ mile to the $\mathrm{NW}$. of which are some dangerous rocks.

Rock.-A white rock 40 feet high, with deep water all around it, lies a little over $\frac{1}{2}$ mile to the southward of Smiths island, and $1 \frac{1}{4}$ miles to the southeastward is a small, flat-topped island from 90 to 125 feet high.

Coast.-The coast north of Angeles bay to within 3 miles of Remedios point is composed of rocky bluffs, with short pebble beaches intervening. The land back of the coast is very much broken, with mountains from 1,500 to 2,000 feet high. Off this rocky strip of coast, near its northern extreme and close to the shore, are three small islets, varying in height from 15 to 30 feet. They are about $1 \frac{1}{4}$ miles distant from each other and the two southern ones are of a whitish color.

Remedios point is low and sandy, with hills rising to the northward and westward, toward the coast range that lies a short distance inland.

Remedios bay is an open bay lying to the southward of Remedios point. It has a shore line of sand and pebble beach about 3 miles in extent, just back of which, near its southern limit, is a small lagoon.

Anchorage may be found here, with shelter from the north westerly winds. The best is off a red hill 200 feet high, $\frac{1}{3}$ mile from the shore, in 10 fathoms of water, Remedios point bearing about N. $30^{\circ}$ E. (N. $18^{\circ}$ E. mag.), distant $1 \frac{3}{4}$ miles.

Coast.-From Remedios point to Bluff point, a distance of 26 miles, the general trend of the coast is NW., and it is an almost unbroken succession of high, rocky bluffs ranging from 50 to 150 feet in height, the cuast range of mountains rising immediately back of it. It affords no anchorage or shelter throughout the entire distance.

Bluff point, the northern point of entrance to Ballenas channel, is a bold, rocky bluff about 100 feet high, and may be recognized from a distance by Sharp peak, 3,189 feet high, which lies $6 \frac{6}{10} 0$ miles $\mathrm{SW}$. by $\mathrm{W} \cdot \frac{1}{4} \mathrm{~W}$. from it. Double peak, 5,440 feet high, bears SSW. $\frac{1}{2}$ W. distant $3 \frac{4}{1^{\frac{4}{0}}}$ miles from Bluff point.

Angel de la Guardia island, which is high, rocky, and barren, is over 40 miles long, in a direction nearly parallel to the coast line, with a great- 
est width of about 10 miles. A range of mountains extends throughout its entire length, varying in height between 3,000 and 4,000 feet, being highest in the northern part. A comparatively low ridge about midway of the island separates the higher northern and southern portions.

The whole western side of the island bordering on Ballenas channel is inaccessible and without any anchorage.

Humbug bay, nearly opposite Remedios bay, has a steep, sandy shore, but the water is said to be too deep, even close to the beach, for a vessel to find anchorage. Just north of this bay is a bold, bluff point, between which and Remedios point, on the mainland opposite, is the narrowest part of Ballenas channel, it being at this place only 8 miles wide.

The southern extreme of the island is a sharp bluff point, a mile to the northward of which is a hill 772 feet high, descending abruptiy to the shore on the east and west sides.

The eastern side of the island is very irregular in its outline. The shore is generally bold, with rocky bluffs predominating. There are several open bays where vessels may anchor and be sheltered from the prevailing winds.

Starting from the southern extreme of the island the coast trends nearly north for a distance of about 3 miles, where it becomes low and assumes a northeasterly direction, terminating in a sharp point, from which a rocky reef, partly dry at low water, connects it with Pond island.

Pond island is about a mile long, with an average width of $\frac{1}{4}$ mile, and over 400 feet high, with vearly perpendicular cliffs, and some outlying rocks on its northeastern side.

Eastward of the reef connecting the two islands, about 300 yards distant from it, is a high detached rock, with a rock awash between it and the reef.

Anchorage may be had, with protection from the northwesterly winds, off a small strip of sand beach that is situated just where the coast commences to curve to the northeastward (about 3 miles from the south point of the island), in from 7 to 9 fathoms of water, less than $\frac{1}{4}$ mile off shore.

Rock point is a bold headland with cliffs over 500 feet high. It is surmouted by a hill 1,943 feet in height, the northeastern end of a spur of - very high and steep mountains projecting from the main range.

The coast between Pond island and Rock point recedes considerably to the westward, forming an open bay in its southern part, where good anchorage may be found with protection from southeasterly winds. The shore near this anchorage is a sand and gravel beach, and the soundings increase gradually seaward.

Anchorage may also be had just south of Rock point, close in shore, in from 5 to 8 fathoms of water, where some protection from the northwesterly winds will be found. 
Coast.-Between Rock point and the next prominent point to the northwestward, a distance of 12 miles, the coast recedes nearly 4 miles, forming a large open bay, the shores of which are for the most part pebble beaches, with a few small bluff points in its southern portion. The land back slopes from a moderately high table land toward the sea and is covered with cactus.

- About 2 miles south of the northern limit of the bay is a small lagoon with a narrow opening to the sea.

From the northern limit of the bay just described the coast trends about NIV. 141 miles to Bluff point, and is a succession of rocky bluffs. Five miles to the northwestward of the northern limit of the bay is a low, slightly projecting point and an arroyo.

Bluff point is the northeastern extremity of the island, and is a bold, rocky headland, with rocky bluffs from 100 to 300 feet in height, extending about a mile on either side of it.

Puerto Refugio, which extends over nearly the whole of the northern side of the island, is a fine large harbor, or more properly two harbors, where good anchorage will be found with shelter from every wind.

These harbors may be entered from three sides, viz: From the east, between Granite island and the northern point of Angel de la Guardia; from the north, between Granite and Mejia islands; and from the west, between Angel de la Guardia and Mejia islands. Either of these entrances may be used with perfect safety.

The eastern and larger of the two harbors is about $1 \frac{3}{4}$ miles in extent either way, and is entirely free from hidden dangers. The best anchorage will be found in the south or southwestern part in from 5 to 10 fathoms of water. Anchorage may also be found sonth of Granite island in from 8 to 12 fathoms, but the bottom is mostly of rock.

Granite island is a little over $\frac{3}{4}$ mile long $\frac{1}{6}$ mile wide, and varies in height from 172 to 281 feet. It is entirely barren and extremely rocky. The eastern point is low and stony, with a white rock 15 feet high lying close to. Off the southwestern end are several detached rocks awash and below water, and a reef, with one rock 13 feet above low water, extends off 200 yards from the northwestern point. The passages on either side of Granite island are over $\frac{3}{4}$ mile wide, with from 15 to 25 and 30 fathoms of water.

White rock is a large, rugged rock of whitish color, 41 feet high, lying nearly in the center of the eastern harbor, with from 7 to 13 fathoms of water close around it.

In the southwestern part of the harbor a spur of hills which terminates in a rocky, bluff point, projects $\frac{1}{4}$ mile into the bay, and from its extremity a rocky shoal extends north ward about 300 yards. 
Directions. - To enter the eastern harbor by either the eastern or northern entrance, bring White rock to bear about midway of the entrance and steer for it, passing it at a reasonable distance, when you may steer for the best anchorage, which is $\frac{3}{9}$ mile due south from it, in $6 \frac{1}{2}$ or 7 fathoms of water, sand bottom.

Mejia island is over $1 \frac{1}{2}$ miles long in and $1 \frac{1}{4}$ miles wide. With the exception of the SF. side, where there are some stretches of sand beach, the coast is a continuous rocky bluff, which attains on the $\mathrm{NW}$. face a height of 500 feet.

South of the easternmost point is a shallow cove of considerable extent, with some small islets in it. Off all the more prominent bluff points are outlying rocks, and from the northernmost point a dangerous reef of rocks, above and below water, extends 800 yards in a NNE. direction. Care must be taken to avoid this reef when using the northern passage into the harbors.

The interior of the island is hilly and barren, with a greatest altitude, near the northwestern point, of 857 feet.

Between the eastern end of Mejia island and the north end of Angel de la Guardia; is an isłand (not named) over $\frac{1}{2}$ mile long, with a greatest width of 400 yards and 250 feet high. It is connected at its southern end by a rocky reef, with Angel de la Guardia, and between its northern end and Mejia island is a channel 150 yards wide, with from 7 to 10 fathoms of water, which connects the eastern with the western of the two harbors.

Western harbor.-The western harbor is a little over a mile in extent with an average width of about $\frac{1}{2}$ mile. It may be entered either at its southwestern end, between the southern point of Mejia island (called Monument point) and a group of rocks lying off the NW. point of Angel de la Guardia, or at its northeastern end, with a leading wind or in a steamer by means of the channel (150 yards wide) that separates Mejia island from the small island before mentioned, lying between it and Angel de la Guardia and connected with the latter by a rocky reef.

Rocks.-About $\frac{1}{4}$ mile to the westward of the NW. point of Angel de la Guardia is a dangerous group of rocks, covered and awash at low water; their outer or western limit is about $\frac{1}{2}$ mile from the point. It is not recommended to attempt the passage between this group and the island.

Sail rock is a sharp, conical rock 167 feet high, lying $1 \frac{3}{4}$ miles S. $49^{\circ}$ W. (S. $37^{\circ} \mathrm{W}$. mag.) from Monument point, with deep water (16 fathoms) close to it.

Directions.-To enter the western harbor from the westward, being north of Sail rock, steer for the middle of the entrance, keeping White rock, in the eastern harbor, in range with the south end of the island that separates the two harbors, until the eastern point of Mejia island bears $\mathrm{N}$. $34^{\circ} \mathrm{E}$. (N. $22^{\circ} \mathrm{E}$. mag.), when you will be in the best anchorage, with from 
6 to 7 fathoms water, bottom of sand and shells. Wishing to pass through into the eastern harbor from the anchorage just described, steer for the north point of the island separating the two harbors, until the center of the channel between it and Mejia island bears N. $27^{\circ}$.E. $\left(\mathrm{N} .15^{\circ} \mathrm{E}\right.$. mag.), when you may steer for it. This will lead through in not less than 4 fathoms water.

Remarks.-Angel de la Guardia island is inhabited by great numbers of iguanas and it also abounds in rattlesnakes, several of which were seen to occupy one hole, near the shore. The interior of the island was not examined and no indications of fresh water were seen.

Coast.-From bluff point, on the mainland, the coast of the peninsula trends about $\mathrm{NW} \cdot \frac{1}{2} \mathrm{~W}$. and with the exception of a small stretch of low beach, 5 miles from Bluff point, is high, rocky, and precipitous as far as Final point, a distance of $20 \frac{1}{2}$ miles. Back of the coast steep hills rise abruptly, attaining, at a distance of a mile from it, a height of over 1,900 feet.

Final point is a rocky, bluff point of moderate height, the land in the interior, southwestward from it, being low.

San Luis Gonzales bay.-From Final point the coast turns sharply to the southwestward, and, sweeping around in a semicircle, forms the open bay of San Luis Gonzales, which affords good anchorage, with protection from southeasters, but is open to the northward. The shore of the bay is a low sand and gravel beach. In the southern part is dry barranca, on the bank of which, 12 miles to the southward, are the ruins of the old nission of the same name, near which are some pools of tolerably good fresh water.

Willards point, the northern headland of San Luis Gonzales loy, is about 8 miles N. $69^{\circ} \mathrm{W}$. (N. $82^{\circ} \mathrm{W}$. mag.) of Final point. Fron Willards point the bay (Willards bay) runs in a northwesterly direction 5 miles, and is then separated from a lagoon by a narrow strip of sand. The lagoon is shallow, and abounds in turtle, fish, and game. The bay is apparently free from hidden dangers, and affords shelter in all weather and from all winds. There is a depth of from 5 to 10 fathoms of water, and even near the mouth of the lagoon there is said to be 5 fathoms within $\frac{1}{4}$ mile from the shore. A poor quality of water was found near the shore of the northern part of the bay. The rise and fall of the tide in Willards bay is said to be 14 feet. Willards point is about 250 feet high, and on its extremity there is a solitary tree.

Coast.- The coast to San Fermin point is for the most part low and sandy, with but few bluffs. The land back of the coast slopes from broken hills and table lands 1,000 to 1,500 feet high, behind which is a range of rugged mountains from 2,000 to upwards of 3,000 feet in height. 
There are several islets off this part of the coast, and the water is comparatively shoal, not more than 12 or 15 fathoms being found 5 or 6 miles from the shore.

San Luis is a small island of volcanic origin lying 13 miles to the northwestward of Final point, with a clear channel $1 \frac{1}{4}$ miles wide between it and the mainland. A low sand spit extends nearly a mile from the southwestern side of the island, with shoal water nearly $\frac{1}{2}$ mile off from it, on either side.

Anchorage.-Good anchorage may be found on either side of the sand spit, on the SE. side with north westerly winds and on the NW. side during southeasters, taking care not to approach on either side within $\frac{1}{2}$ mile.

Cantada island, about 400 yards from the northern end of San Luis island, and connected with it by a reef that is bare at low water, is a rocky islet 478 feet high. A mile and a quarter N. $11^{\circ} \mathrm{W}$. (N. $24^{\circ} \mathrm{W}$. mag.) from Cantada island there is a dangerous rock about 3 feet above low water, with 19 fathoms close to it, and $2 \frac{1}{2}$ miles N. $43^{\circ} \mathrm{W}$. (N. $56^{\circ} \mathrm{W}$. mag.) from Cantada there is a reef, nearly circular and over $\frac{1}{2}$ mile in diameter, of rocks both covered and awash at low water, with deep water close to.

Another rock, awash at low water, lies a mile nearly due north from the NW. end of San Luis island.

Islets.-Parallel to the coast, and from 3 to 4 miles from it, are three small islets varying in height from 300 to 600 feet. They are distant from San Luis island, respectively, 4, 6, and 9 miles. A third of a mile eastward of the southernmost of these islets is a large outlying rock. From the middle islet a low sand spit and shoal extends over $\frac{1}{2}$ mile to the southwestward.

About 5 miles northwestward of the northernmost, and less than a mile from the adjacent mainland, is a large rock, 75 feet high.

Red bluff is a conspicuous bluff, of a reddish color, 100 feet high, back of which is a series of table-shaped hills from 1,000 to 1,500 feet high.

From this point the coast line assumes a more northerly direction.

San Fermin point is a low sand point, not well defined. Just southward of it is an anchorage with some protection from the north westerly winds. A rugged peak, 3,413 feet high, known as Rugged peak, lying $10 \frac{3}{4}$ miles WSW. from San Fermin point, serves as a good landmark. Springs rise about 18 feet.

From San Fermin point the general trend of the coast is north as far as Diggs point, a distance of 27 miles, whence it falls away to the westward, San Felipe point bearing N. $32^{\circ} \mathrm{W}$. (N. $45^{\circ} \mathrm{W}$. mag.) 13 miles distant from Diggs point. The shore throughout the entire distance is low and sandy, the coast range, a few miles in the interior, rising to a height of about 1,000 feet.

The soundings at from $2 \frac{1}{2}$ to 4 miles off shore show a depth of from 8 to 15 fathoms. 
Diggs point is low and sandy, projecting only slightly from the general coast line. A range of hills approaches the coast near it.

San Felipe point is a dark rocky headland surmounted by a dark hill which rises abruptly to a height of nearly 1,000 fect. San Felipe bay lies just south of the point; it is small in extent, but affords some shelter from the northwesterly winds. The shore of the bay is for the most part low and sandy, but in the northwestern part there are some rocky bluffs, and back of them, rising from a plain, are a number of conspicuous hills of conical shape and moderate height. The water in the bay is quite shoal, less than 3 fathoms (at low water) being found a mile off shore.

Anchorage.-The best anchorage is in the northern part of the bay, on the following bearings, viz: Dark hill surmounting San Felipe point N. $35^{\circ} \mathrm{W}$. (N. $48^{\circ} \mathrm{W}$. mag.) ; sharp white peak, a conspicuous peak 4,288 feet high, S. $64^{\circ} \mathrm{W}$. (S. $51^{\circ} \mathrm{W}$. mag.). This will place you in from 4 to 5 fathoms (at low water), muddy bottom. Spring tides rise about 20 feet.

Calamahue mountain, sometimes called Santa Catalina mountain, from the old mission of that name near its foot, lies $28 \frac{1}{2}$ miles westward of San Felipe point. It has a whitish appearance, with a jagged top, and is the highest mountain in Lower California, having an elevation of 10,126 feet above the sea level, and can be seen in clear weather from a distance of over 100 miles.

The Cocopa Indians, who inhabit some parts of this region, report the existence of gold there, and they occasionally come to the Colorado river, bringing nuggets of pure gold with them, which they trade off.

Lake.-There is said to be in the vicinity of mount Calamahue a large mountain lake which feeds the various small streams that flow toward the Pacific coast.

Consag rock, sometimes called Ship rock, from its resemblance to a ship under sail, lies $18 \frac{1}{2}$ miles N. $78^{\circ}$ E. (N. $65^{\circ}$ E. mag.) from San Felipe point. It is small in extent, 286 feet high, and covered with guano, which gives it a whitish color. A number of detached rocks lie from $\frac{1}{4}$ to $\frac{1}{2}$ mile to the westward of it, some of them over 25 feet high. Soundings between it and San Felipe point show from 10 to 15 fathoms of water, with generally muddy bottom. The tidal currents cause heavy rips in this vicinity.

This rock is an excellent mark for shaping a course to the mouth of the Colorado river.

The coast from San Felipe point to the mouth of the Colorado river, a distance of about 30 miles, trends nearly due north, and is low, with plains rising gradually toward the mountains in the interior. Mud flats and shoals, which are bare at low water, extend off shore from $1 \frac{1}{2}$ to 6 miles. Parts of this coast are subject to overflow at the time of heavy freshets and highest spring tides. 
Ometepes bay (named by an exploring party on the steamer Ometepes), situated about 20 miles southward of Robinsons' landing, Colorado river, in latitude $31^{\circ} 30^{\prime} \mathrm{N}$., longitude $114^{\circ} 52^{\prime} \mathrm{W}$., has an entrance 300 feet wide and $\frac{1}{4}$ mile in length, with a depth of 3 fathoms of water at half tide. The bay, circular in form, is about 3 miles wide, and free from hidden dangers. It is perfectly landlocked, and has a depth of 5 fathoms of water. The rise and fall of the tide is said to be 25 feet. The bay abounds in turtle, fish, and game.

Colorado river.-The entrance to the Colorado river may be considered as lying between Shoal point, on the Sonora shore, and a point 27 miles due west from it, on the coast of the peninsula of Lower California. It is much obstructed by mud flats, which are bare at low-water springs, but have navigable channels between them at high water. There are also two islands, called Montague island and Gore island, which are subject to overflow at high-water springs.

The main channel, through which $2 \frac{1}{2}$ fathoms may be carried at ordinary low water as far as Philips point, lies close along the Sonora shore.

Shoal point is a low, sandy point, with a barren sand hill about 300 feet high immediately back of it. The water is shoal for about $\frac{1}{2}$ mile off the point, and there is a shoal spot with $2 \frac{1}{2}$ fathoms, least water lying from 2 to 4 miles about northwestward of it. Between this shoal and the shore there is a channel over $\frac{1}{4}$ mile wide, with from 5 to 7 fathoms of water.

About 9 miles NW. by W. of Shoal point the beach projects slightly, and back of it are some sand cliffs at the foot of the hills which form the lateral spurs of a long, barren table land.

Direction sandhill, which lies back of the above-mentioned projecting beach, is 556 feet high, and easily recognizable from the neighboring hills by a growth of bushes at its foot. It is an excellent mark for entering the river.

Off the point just mentioned is a shoal with only 9 feet of water in its shoalest part. Between it and the shore is a channel $\frac{3}{4}$ mile wide, through which 6 fathoms may be carried at low water. There is also a channel about a mile wide, with 5 and 6 fathoms of water, west of the shoal, between it and an extensive mud flat which is bare at low-water springs.

Santa Clara beacon is on the west side of the mouth of the river of the same name and consists of a couple of piles driven in the ground, with a piece of board nailed across the top. It is about 10 miles from the low point fronting Direction sandhill.

Santa Clara river is only navigable at high water. At low-water springs it is dry, with the exception of here and there a pool of water. 
From the junction of this river with the Colorado, the sand hills and table lands, which up to this point have run parallel with the coast, assume a more northerly direction, following the course of the Santa Clara river.

Beacons. - White beacon is 5 miles N. $77^{\circ} \mathrm{W}$. (west mag.) from Santa Clara beacon. It is of piles, with a triangular cage fastened on them, and stands on a shoal spit making off from the western side of the mouth of an extensive slough.

On the opposite side of the slough, 400 yards N. $19^{\circ}$ E. (N. $6^{\circ}$ E. mag.) from White beacon, is a beacon in form of a cross.

These two beacons serve as guides for entering the slough and for avoiding a shoal which extends a short distance off its mouth.

Port Isabel is abandoned. The black beacon on Philips point has disappeared and a temporary one has been put up in its place. None is really necessary, as the point itself is prominent and can be seen, except possibly at springs or floods.

Philips point may be regarded as the head of deep-water navigation in the Colorado river. Above it the channel soon becomes very shallow and tortuous.

The north shore of the river from the mouth of the Santa Clara to Philips point and for several miles beyond is an almost level alluvial plain, subject to overflow at high spring tides.

Montague island, lying abreast of Philips point, on the south side of the main channel, is a low, flat island about 6 miles long, with a greatest width of 3 miles. It is covered with coarse grass and scattered driftwood and logs, the latter giving evidence that it is subject to overflow at the time of freshets.

There is a passage between it and the right-hand or western bank of the river, which may be used at high water by small vessels, but is entirely bare at low-water springs. Southward of the island, along the Lower California shore, a mud bank, bare at low-water springs, extends for nearly 9 miles.

Gore island, similar in character to Montague island, lies $\frac{3}{4}$ mile eastward of the southern part of the latter, separated from it by a channel in which there is at all times over a fathom of water, excepting a narrow bar (400 yards wide), where it joins the main channel, opposite Philips point, which is just bare at low-water springs. Gore island is 2 miles long north and south, $\frac{3}{4}$ mile wide, and has a mud bank, similar to that south of Montague island, extending off from it to the southward and eastward.

Channel.-About 3 miles eastward of Gore island, between the mud bank extending off from it and another similar mud bank 13 miles in length, which lies on the SW. side of the main channel, is a channel nearly a mile wide, through which $1 \frac{1}{4}$ fathoms may be carried. It joins the main channel nearly opposite the mouth of the slough. 
Caution.-It will not do to trust to compass courses, as the currents will sweep you a long way off the line. The lead must be kept continually going, as the shoals and mud flats are subject to frequent changes. Do not enter the river on the ebb tide, but take advantage of the first of the flood.

Currents. - The tidal currents run with great strength at full and change of the moon, sometimes as much as 6 knots per hour, and there is no such thing as slack water. When leaving the anchorage, bound out of the river, start on the last of the ebb.

Remarks.-The Colorado river is navigable for light-draft vessels as far as Colville, Nevada, which is about 600 miles above Philips point. The influence of the tide is felt for about 40 miles, up to a place a few miles above Heintzelmans point, and at a short distance above Philips point, at or near the time of spring tides, comes in with a bore or bank of water 4 feet high, extending in one huge breaker clear across the river, while the ebb is still running out.

Above Philips point the channel is crooked and obstructed in places by sand bars, some of which have at times not more than 2 feet of water over them. The channel retains an average width of nearly $\frac{1}{2}$ mile the entire distance to Colville. The winds at the mouth of the river are mostly from the NW., and in summer are very dry and hot.

The principal exports from the river are hemp, which grows wild in great abundance, argentiferous lead ores and copper ores. The river trade is in the hands of the Colorado Steam Navigation Company, which has three river steamers and three barges of from 70 to 100 tons burthen employed. These vessels draw about one foot of water when light and two feet when loaded. 


\section{CHA PTER I I I.}

THE COAST OF MEXICO AND ADJACENT ISLANDS FROM THE MOUTH OF THE COLORADO RIVER TO CAPE CORRIENTES.

Remarks. - The coast of Mexico, from the mouth of the Colorado river to cape Corrientes, bordering partly on the gulf of California and partly on the Pacific ocean, is for the most part low and sandy, although there are many places where the mountains approach it closely. In the distant interior may be seen the summits of the Sierra Madre and of the high mountain ranges branching off from it.

The Mexican provinces on this coast are, commencing at the Colorado river, Sonora, Sinaloa, and Jalisco, having together a population of $1,535,000$. The climate is temperate and the interior of the country is fertile, but the principal sources of wealth are the mines of gold and silver that are found almost everywhere.

There are many places along the coast where vessels may anchor, and several important ports, among which are Guaymas, Mazatlan, and San Blas.

The depth of water off this coast is in general much less than that off the western coast of the gulf of California.

The islands off the coast are generally barren and uninhabited. Tiburon island, in the upper part of the gulf, is inhabitated by the Seris tribe of Indians.

Currents.-The information regarding the currents along this coast is rather meager and the statements somewhat contradictory. They probably depend almost entirely on the winds, southerly currents predominating.

Between Guaymas and cape Corrientes, during the rainy season (from May to November), they are strong and irregular. Northerly currents are frequently encountered at that season. Tide rips are often seen along the edge of the shoals that lie off this part of the coast.

Coast.-From Shoal point, the eastern point of entrance to the Colorado river, the coast trends about ESE. for a distance of 10 miles, and is generally low, with here and there a sand hill of moderate height. Shoal water extends off this part of the coast to distances varying from $\frac{1}{2}$ mile near Shoal point to 2 miles at a point 10 miles to the eastward of it.

Adair bay is a large bay entirely open to the southward, and is not navigable for even the smallest coasters, being full of dangerous, shifting shoals. Its western limit is 10 miles eastward of Shoal point, from whence Rocky 
bluff, the eastern limit, bears S. $69^{\circ}$ E. (S. $82^{\circ}$ E. mag.), distant $25 \frac{1}{2}$ miles, the coast between falling away 10 miles from a line drawn between the two limits. The shore of the bay is low and sandy, with occasional rocky patches. In its northern part is a lagoon opening into the bay, with several sand spits at its entrance which project 2 or 3 miles into the bay and are dry at low water. Low plains, with surface deposits of soda, extend far into the interior.

Pinacate mountain lies about 19 miles in a northeasterly direction from Adair bay. It is 4,235 feet high, and is the last high mountain seen on this coast when coming from the southward.

Rocky bluff is a bold, rocky point of a dark color, surmounted by a sharp hill 408 feet high.

A small bight on its northern side is shoal and partly dry at low-water springs, but on its western and southern face 5 and 6 fathoms will be found close to, with no outlying dangers. The land back is low and sandy. A conspicuous, dark-colored, solitary hill, 426 feet high, called Flat hill, lies $4 \frac{1}{2}$ miles to the northeastward of the point.

Rocky point lies 5 miles ESE. of Rocky bluff, and is like the latter in its general character. The hill surmounting it is 226 feet high.

Rocky Point bay.-Between Rocky bluff and Rocky point the coast recedes somewhat, forming a small open bay called Rocky Point bay, where anchorage may be had in from 5 to 7 fathoms water, on a line between the two points, with shelter from the northwesterly winds. The shore of the bay is sandy, and covered with bushes. Shoal water makes off from it about $\frac{1}{2}$ mile.

Georges bay.-From Rocky point the coast falls away to the eastward, having a general trend ESE. $\frac{1}{2}$ E. for a distance of about 22 miles, and then gradually assumes a southerly trend, forming a large open bay, known as Georges bay.

The shores of the bay are low and sandy ; back of them are plains reaching to the foot of mountains well in the interior.

Six miles eastward of Rocky point is the entrance to a lagoon, into which small vessels may pass at high water; and from 9 to 10 miles farther east are some salt lagoons lying a short distance back of the beach and having no apparent communication with the waters of the bay.

Southeastward from these lagoons the water is shoal for from 1 to 3 miles off shore.

A mountain range approaches to within 5 or 6 miles of this part of the coast, the most conspicuous peak of which, called Table peak, is 1,366 feet high and flat topped.

Georges island lies 23 miles S. $43^{\circ}$ E. (S. $56^{\circ}$ E. mag.) from Rocky point. It is a barren rock, about 1,200 yards in length and 600 in width ; 
its highest peak, near the SE. extremity, is 206 feet high. Some rocks above water and awash extend a little over $\frac{1}{2}$ mile from it, in a northwesterly direction.

This island is covered with guano, which has been worked to some extent. Immense numbers of sea fowl inhabit it, and a great many seals were seen along the rocky shore.

A fair anchorage, with protection from a SE. wind, may be found to the northward of the island, in $3 \frac{1}{2}$ fathoms water.

Shoal.-Four miles to the northeastward of Georges island is an extensive and dangerous shoal, which makes off 3 miles from the western side of a low, sandy point that projects from the southeastern shore of Georges bay. There are from 3 to 6 feet of water over this shoal at low-water springs. Between it and the island is a channel, with from 4 to 7 fathoms of water.

From abreast of Georges island the coast trends nearly south for 20 miles and then gradually falls away to the eastward. . Cape Tepoca is $49 \frac{1}{4}$ miles from the observation spot on Georges island. As far as San Ignacio river it is low and sandy, with sand hills from 20 to 60 feet high. Southward of San Ignacio river the coast is higher, the hills approaching nearer the sea.

The soundings off shore increase gradually, the 3 -fathom line being from $\frac{1}{2}$ mile to $1 \frac{1}{2}$ miles from the beach.

Shoal.-Seven miles S. $20^{\circ}$ E. (S. $33^{\circ}$ E. mag.) of Georges island and 5 miles from the mainland, a shoal spot on which there were from $4 \frac{3}{4}$ to 6 fathoms of water was passed over, there being 8 and 9 fathoms north and south of it, at the same distance from the shore of the mainland.

San Ignacio river has an extensive shoal off it, over which the sea breaks heavily at times. The river as it approaches the coast loses itself during the dry season in the sand, only breaking through to the gulf during the rainy season. Near the south bank of the river, about a mile from the coast, are some Indian huts and a well; fresh water may be procured at all times just back of the sand hills. The banks are covered with vegetation, and game is plentiful in the vicinity. About 75 miles from its mouth is the town of El Altar, and 69 miles beyond is San Ignacio, with its renowned mining district (gold and silver). The mouth of the river is readily distinguished by the break in the sand hills, through which it passes to the gulf. The northern extremity of the coast range of mountains is just south of the river.

Cape Tepoca, or Tepoca hill as it is sometimes called, lies $17 \frac{3}{4}$ miles southeastward of the mouth of the San Ignacio river, the coast between sweeping about 3 miles to the eastward. It is of a reddish color and 300 feet high; when first seen from the northward it appears like an island. 
Tepoca bay.-From cape Tepoca a low, rocky point makes out to the southeastward about $\frac{1}{2}$ mile, having a reef and large rock partly covered at high water extending off from it about $\frac{1}{4}$ mile farther in the same direction. This point and reef form the western limit of Tepoca bay, which is entirely open to the southward and about $2 \frac{1}{2}$ miles in extenteast and west. The northern shore of the bay is low and sandy, covered with bushes; the eastern shore is bluffy, with the coast range rising a short distance back.

Anchorage.-There is good anchorage in Tepoca bay, sheltered from the northwesterly winds, in 5 or 6 fathoms at low water, $\frac{1}{2}$ from the shore. Spring tides rise about 15 feet, neaps about 12 feet.

A flat-topped hill, 1,575 feet high, bearing N. $60^{\circ}$ E. (N. $47^{\circ}$ E. mag.), $6 \frac{1}{2}$ miles distant from cape Tepoca, is an excellent guide to the anchorage in Tepoca bay when coming from the southward.

Coast.-From cape Tepoca the coast turns sharply to the eastward and trends in that direction for $2 \frac{1}{2}$ or 3 miles, when it again assumes a southerly trend to cape Lobos, 23 miles distant. For about 10 miles southward of the eastern limit of Tepoca bay, sand cliffs from 25 to 50 feet high lie just back of the beach; thence to cape Lobos the coast is generally low and sandy, the coast range approaching the shore. Fourteen and a half miles SSE. $\frac{1}{2}$ E. from Tepoca point a peak, 1,642 feet high, rises immediately back of a steep shore. Lobos peak, 3 miles north of the cape of the same name, is 1,186 feet high, and somewhat less than $\frac{1}{2}$ mile from the shore.

Cape Lobos is a rocky headland of the same character as cape Tepoca; near it are three hills, close together, the westernmost and highest of which is 669 feet high.

Vessels may approach the cape closely, 5 and 6 fathoms of water being found at 200 yards distant from it.

The entire distance from cape Tepoca to cape Lobos appears to be free from outlying dangers, the water shoaling gradually toward the shore.

Libertad Anchorage.-At cape Lobos the coast again turns sharply to the eastward, trending in that direction for $3 \frac{1}{2}$ miles, when it assumes a southeasterly trend. The open bay or bight thus formed is known as Libertad anchorage, where a vessel will be well protected from the northwesterly winds, but exposed to southeasters. The best place to anchor is from $\frac{3}{4}$ mile to a mile eastward of the cape and a scant $\frac{1}{2}$ mile off shore, in 8 or 9 fathoms.

Two and a half miles eastward of the cape, a sandy beach intervening, is a low projecting point, from which a shelving, rocky ledge and numerous detached rocks extend 400 yards in a southerly direction. Back of this point are some houses, one of which is used as a customhouse.

Three fathoms of water are found close to the sandy beach just mentioned. 
Libertad is a shipping point for some of the agricultural and mineral products of the province of Sonora.

Coast.-From cape Lobos to cape Tepopa, a distance of $36 \frac{1}{2}$ miles, the general trend of the coast is SSE. $\frac{1}{2} \mathrm{E}$. The shore consists for the most part of sand and shingle beaches, with occasional rocky bluffs intervening, the coast range rising to elevations varying from 500 to 2,300 feet, a short distance back of it. One or two small patches of kelp were met with along this part of the coast, close to the shore.

Eight and a half miles north of cape Tepopa is a low, slightly projecting. point, off which a shral, with from $2 \frac{1}{2}$ to 3 fathoms of water on it, extends nearly $\frac{3}{4}$ mile. With this exception the coast is clear, the water shoaling gradually toward the shore, from 15 to 30 fathoms being found a mile off.

Northivard of cape Tepopa a curve in the coast line forms a sort of open bay, which, however, affords no protection whatever from the prevailing winds. The shore of this bay is low and sandy; back of it, low plains covered with bushes stretch far into the interior.

Cape Tepopa is a bold rocky headland surmounted by a peak 1,857 feet high.

Tepopa peak is the northernmost and highest of a small group of hills that lie parallel to the coast, and are separated from the coast range, which lies 5 miles to the eastward, by low sandy plains.

Sargents point is $6 \frac{1}{2}$ miles to the southeastward of cape Tepopa. It is a barren, rocky hill, 150 feet high, at the southern extremity of a low, narrow neck of land that is subject to partial overflow at high-water springs; the coast between it and cape Tepopa is low.

Just west of the point a curve in the coast line forms a small bight, where tolerable anchorage may be found in 7 fathoms of water, $\frac{1}{2}$ mile from the shore.

East of Sargents point is a small bay, but the water in it is too shoal for it to be of any value. The beach of this bay is very flat, the low-water line being from $\frac{1}{2}$ mile to a mile outside that of high water.

At the NW. side of the bay is the outlet of a lagoon that lies parallel to the north shore, a narrow strip of sand intervening between it and the waters of the bay. Back of the lagoon is the low sandy plain before mentioned as intervening between the group of hills near cape Tepopa and the coast range.

The mainland, from Sargents point to San Miguel point, a distance of over 20 miles, has a southeasterly trend, and is for the greater part of the distance low and sandy, with a scattered growth of bushes.

Patos island, the $\mathrm{NW}$. point of which lies $5 \frac{3}{4}$ miles S. $20^{\circ} \mathrm{W}$. (S. $8^{\circ} \mathrm{W}$. mag.) from cape Tepopa, is small in extent, and, except on the NW. side, where it rises in a conical hill to a height of 274 feet, is low. A deposit of guano gives it a whitish appearance. 
The passage between Patos island and the mainland, as well as that between it and Tiburon island, is perfectly safe, with a least depth of 7 fathoms, near the land.

Anchorage.-There is a tolerable anchorage on the southern side of Patos island, with some protection from a northwesterly wind, in 5 fathoms of water, sandy bottom, $\frac{1}{4}$ mile from the beach. In using this anchorage care should be taken not to approach the low shingle point that makes off from the SW. side of the island, nearer than $\frac{1}{4}$ mile, as shoal water extends off some distance from it.

Tiburon is the largest island in the gulf of California, being about 29 miles long, nearly north and south, with an average width of 15 miles. It is high and rugged, with peaks varying in height from 1,000 to nearly 4,000 feet. A narrow, intricate channel called El Infiernillo separates it from the mainland to the eastward.

The NW. extreme is a rocky bluff surmounted by a steep hill 1,123 feet high. Some detached rocks lie a short distance off; $5 \frac{3}{4}$ miles to the eastward of this is a high bluff point, the northern extremity of the island, between which and Sargents point is a channel $4 \frac{1}{10}$ miles wide with 7 and 8 fathoms of water.

Freshwater bay is formed by a curve in the coast line between the north and NW. extremes of the island. It affords an anchorage in from 5 to 7 fathoms of water, $\frac{3}{4}$ mile from the shore, with shelter from southeasters, but is entirely open to the NW.

The land back of the bay slopes gradually toward the mountains in the interior of the island and presents a fertile appearance.

The NE. point of the island is $3 \frac{4}{10}$ miles eastward of the north extremity, and the same distance from the nearest mainland to the northeastward. A sandy islet, 5 feet high, lies in the prolongation of the point, connected with it by a shoal over which the water breaks. In the channel between the islet and the mainland are 3 and 4 fathoms of water, near the islet.

The eastern side of the island, from the NE. extreme to a low projecting point opposite San Miguel point on the mainland, a distance of about 15 miles, is, with the exception of a short stretch of bluffs, 10 to 20 feet high, low, sandy, and covered with a scanty growth of bushes.

This part of Tiburon island is separated from the mainland by a channel varying in width from 1 to 3 miles, and called El Infiernillo. In its southern part from 5 to 7 fathoms of water are found, and it is comparatively free from shoals, but in its northern psrt the water is shallow, and it is full of shoals and sand spits. It is unsafe for navigation by any except the smallest class of vessels. Half a mile northward of San Miguel point is a small lagoon with shoal water off its mouth.

From the low point (before mentioned) opposite San Miguel point to the southeastern extreme of the island it is $13 \frac{1}{2}$ miles, the shore line trending $11562-7$ 
about S. by W. For the first 8 miles of this distance the shore is low and sardy, with shoals and sand bars extending from $\frac{1}{2}$ mile to $1 \frac{1}{4}$ miles off from it. The remainder is a steep coast, with rocky bluffs near the SE. point of the island, and the water near the shore is deeper, from 5 to 7 fathoms being found $\frac{1}{4}$ mile off shore.

The SE. point of the island is a high headland situated at the extremity of a peninsula that projects a mile from the main body, and is $\frac{1}{2}$ mile in width. There are two hills on this peninsula, separated from each other by a strip of low land which forms a shallow basin for the reception of water during the rainy season.

On the north side of the peninsula just mentioned, good anchorage will be found in 5 or 6 fathoms of water, sheltered from the prevailing winds. A sand beach at the junction of the peninsula with the main body of the island affords a landing place.

Monument point, the southernmost point of Tiburon island, is a rocky bluff point, situated $3 \frac{3}{4}$ miles from the SE. extremity of the island. The intervening coast is a sand beach, and recedes $\frac{1}{2}$ mile from a line drawn between the two points.

Turners island is a small barren island, about $1 \frac{1}{4}$ miles in length north and south, $\frac{1}{2}$ mile wide, and 550 feet high, lying $1 \frac{1}{4}$ miles to the southeastward of Monument point. A reef of rocks, both above and below water, extends $\frac{1}{2}$ mile off from its northern end, leaving a narrow boat passage between it and Seal rock.

Seal rock is a rocky islet 150 feet high, lying between Turners island and Monument point. There are numerous outlying rocks surrounding it, but there is a clear channel $\frac{1}{4}$ mile wide, through, which 5 fathoms of water may be carried between it and Monument point.

At 1,200 yards southwestward of the above-mentioned islet there is a dangerous rock, awash at high water.

Red Bluff point is a sharp, rocky point of a reddish color and about 150 feet high, situated $2 \frac{1}{2}$ miles to the westward of Monument point.

Anchorage.-Between Monument and Red Bluff points the coast recedes about $\frac{3}{4}$ mile, forming a small bay, open to the southward, in which good anchorage may be found in 5 or 6 fathoms, $\frac{1}{4}$ mile from the shore, which is a sand beach, with shelter from the $\mathrm{NW}$. winds. About midway between the two points mentioned above there is a slightly projecting rocky point with an arroyo just east of it.

Willards point, the southwestern extreme of the island, is a bold cliff over 300 feet high, surmounted by a hill about 800 feet in height. There is said to be a tolerable anchorage about $1 \frac{1}{2}$ miles eastward of it, in 7 fathoms of water, close to the shore.

At $3 \frac{3}{4}$ miles eastward of Willards point, and 300 yards from the shore, there is a large detached white rock 30 feet high. 
Western shore of Tiburon.-The western shore of the island from Willards point to its northwestern extremity, a distance of 21 miles, is for the most part steep, with rocky bluffs, the mountains rising abruptly just back of the coast.

The general trend of the coast from Willards point is N. by E. $\frac{1}{2} \mathrm{E}$., and it is for the greater part clear of dangers, with deep water close to. One and a half miles northward of Willards point, and less than 200 yards off shore, there is a detached rock 8 feet high, and $11 \frac{1}{2}$ miles farther north is another similar rock. Near the NW. extreme of the island there are a number of outlying rocks close to the shore.

Remarks.-During the greater part of the year Tiburon island is the resort of the Seris (or Ceres) tribe of Indians, who inhabit the adjacent mainland, and their huts and encampments can be seen in many places along the shore, principally on the eastern side of the island. They are reputed to be exceedingly hostile, but during the stay of the Narragansett in the vicinity they were friendly. At first they were shy and made threatening gestures, but soon, finding that no harm was intended, they became friendly, and returned visits made to the shore by frequent and lengthy calls on board ship. A species of large deer is found in great numbers on the island. A rich bed of pearl oysters is said to exist in the channel between the island and the coast of Sonora, and there are reports of rich gold mines on the island, but these reports need confirmation.

San Esteban is a barren, rocky island lying $7 \frac{3}{4}$ miles south of the southwestern point of Tiburon. It is 4 miles long north and south, about 3 miles wide, and from 1,000 to 1,800 feet high. On its eastern sidé, a mile from the SE. point, is a rock 25 feet high, $\frac{1}{4}$ mile from the shore, to which it is connected by a rocky reef. Just north of this rock and reef is a gravel beach, from which a valley slopes toward the interior of the island. From the southwestern part a low shingle spit makes off $\frac{3}{4}$ mile, the soundings on either side of it increasing rapidly. The remaining shores of the island consist of almost perpendicular bluffs, varying in height from 100 to 500 feet, with short stretches of gravel and shingle beaches intervening.

Channels.-The channels between San Esteban and Tiburon on the north and San Lorenzo on the west are free from dangers, with soundings of 100 fathoms and upwards.

San Miguel point, on the Sonora coast, is low, sandy, and covered with bushes. A shoal with 3 fathoms of water at its outer edge makes off $\frac{3}{4}$ mile from its southern side.

From here the general trend of the coast is about SE. For a distance of 4 miles it is low and sandy, then follow steep bluffs, terminating in Dark bluff, 175 feet high, back of which, a short distance inland, a sharp peak rises to a height of 1,480 feet. After passing Dark bluff the coast becomes low again. 
Kino point is $17 \frac{3}{4}$ miles distant from San Miguel point and is a prominent point, of moderate elevation, with a group of hills, the highest of which reaches an altitude of 1,336 feet, rising a short distance back of it.

The soundings between Kino point and Tiburon are very regular, but show comparatively shoal water, 14 fathoms being the greatest depth obtained.

Kino bay lies just north of the point. Throughout the greater part of its extent the water is shoal, but small vessels may anchor in it and find shelter from the prevailing winds. Tides rise about 6 feet.

Pelican island, in the northern part of Kino bay, lies 3 miles from Kino point and a little over a mile from the nearest mainland to the eastward, the channel between it and the mainland having a greatest depth of $1 \frac{3}{4}$ fathoms. It is small in extent and 540 feet high. Its shores, with the exception of the southwestern face, which is of rocky bluffs, are low and sandy. In its northern part is a small lagoon.

La Cruz lagoon, which has several branches spreading out through a low, flat country, opens into the head of Kino bay. The entrance, which is $\frac{1}{2}$ mile wide, has a greatest depth of 2 fathoms, but a bar which extends off from it a short distance has only $1 \frac{1}{2}$ fathoms on it.

The Sonora river, which rises near the southern boundary of Arizona and with its tributaries drains the greater part of the province of Sonora, divides into several branches, which disappear in the low country surrounding La Cruz lagoon. Ures, the capital of Sonora, and Hermosillo, an important city, are situated on the banks of the rio Sonora. The rio de la Poza, which, like the rio Sonora, divides and disappears in the San Juan Bautista flats during the dry season, overflows them in the wet season, carrying vast quantities of sand into the gulf and creating extensive shoals along this part of the coast.

Shoal.-At $22 \frac{1}{4}$ miles southeastward of Kino point, a low, sandy point projects over a mile from the general coast line, and a sandy shoal, with 3 fathoms of water on its outer edge, extends over $3 \frac{3}{4}$ miles off from the point to the southivestward.

Caution.-Care should be taken to give this shoal a good berth, as appearances seem to indicate that it is increasing in extent to the SW. and west. Only 6 fathoms of water are found 5 miles to the westward of the low sand point.

The Estero de Tastiota has a narrow entrance, through which only 3 feet of water can be carried at high tide. Outside the entrance the water is shoal for about a mile off shore; inside it expands to a considerable size, trending to the northward, a range of hills rising behind it. Fresh water may be obtained near the head of the estero.

Anchorage may be had in good weather off the mouth of the estero de Tastiota in 6 or 7 fathoms of water $\frac{1}{2}$ mile off shore. 
Morro Colorado is a remarkable headland 758 feet high and of a reddish color. It is situated a little less than 5 miles southeastrvard of the entrance to the estero de Tastiota, the intermediate coast consisting of steep bluffs from 50 to 75 feet high, with a number of outlying rocks. Hills rise immediately back of the coast.

From morro Colorado to San Pedro point, a distance of $17 \frac{1}{2}$ miles, the coast trends SE. by S., and is high and barren; rugged, bluff points from 300 to 500 feet high alternating with short, steep stretches of sand beach. Throughout the entire distance there is no shelter from the prevailing winds, nor any safe anchorage. A number of detached rocks awash and above water lie off this part of the coast.

Las Piedras Blancas are three white rocks, one of which is 60 feet high and the other two 15 feet in height. The largest of these rocks lies 7 miles southeastward of morro Colorado, and a little over $\frac{3}{4}$ mile from the shore; the other two lie from $1 \frac{1}{4}$ to $1 \frac{3}{4}$ miles on either side of it-one to the northward, the other to the southeastward.

Another group, consisting of four rocks, varying in height from 15 to 100 feet, lies between 3 and 4 miles to the northward of San Pedro point and less than $\frac{1}{4}$ mile from the shore.

San Pedro point is a bold, rocky headland 525 feet high.

San Pedro bay is a small cove lying to the southeastward of the point. The entrance, which is $\frac{3}{8}$ mile wide, lies between two steep rocky heads, and has a depth of from 5 to 8 fathoms. The head of the bay, which is somewhat less than $\frac{1}{2}$ mile from the entrance, is a sand beach, with a range of hills lying back of it. The soundings decrease gradually towards the shore. Tides rise about 5 feet.

Anchorage will be found about midway of the entrance, in from 5 to 6 fathoms of water, with shelter from the NW. winds.

San Pedro Nolasco island is a barren rock of volcanic origin, lying $8 \frac{1}{4}$ miles to the southwestward of San Pedro point. It is $2 \frac{1}{4}$ miles in length, parallel with the coast, $\frac{3}{4}$ mile wide in the center, and varies in height from 500 to 1,071 feet. There is a place on the SE. side where a landing may be effected; in every other part it is inacessible. Some deposits of guano are said to exist on it. Off the southern extreme there are some outlying rocks close to, elsewhere the water is deep close to the bluffs. Soundings of 35 and 40 fathoms were obtained along the eastern side, 200 yards off shore.

Southeastward of San Pedro point the coast has the same rugged character as above it, for a distance of $5 \frac{1}{4}$ miles, or as far as San Eduardo point, which is a rocky, bluff point 60 feet high, the land back of it sloping from a mountain $2 \frac{1}{4}$ miles distant and 2,422 feet high, known as Algodones. 
Three-quarters of a mile to the southeastward of San Eduardo point and close to the shore is a small islet, or rock, 40 feet high, with a rock awash just outside of it.

Between San Eduardo point and San Antonio point, a distance of 51 miles, the coast is low and generally sandy. Southward of Algodones mountain, close to its foot and $\frac{1}{2}$ mile from the beach, is a ranch, with fresh water and considerable cultivated ground in the vicinity.

The Algodones are three small islands lying about $1 \frac{1}{2}$ miles to the northwestward of San Antonio point. They extend about a mile in a line nearly at a right angle with the coast line, and the largest is a little over 200 yards in width.

Venado, the outermost and largest of the three, is about 150 feet high, steep and rocky. About 800 yards east of its SW. extremity lies a solitary rock 5 feet above water.

San Luis, the second in size of the Algodones islands, is about 30 feet high, with a passage less than 150 yards wide between it and the mainland.

At 200 yards to the northward of the NE. end of San Luis is the entrance to a small lagoon.

Doble, the smallest of the three islands, lies between the other two.

San Antonio point is low and rocky, the hills back of it rising to a moderate height. On its $\mathrm{NW}$. side, close to, is an outlying rock 30 feet high.

Along this part of the coast the soundings show deep water close to the shore, 23 fathoms being found within $\frac{1}{2}$ mile of the point, increasing to over 100 fathoms $3 \frac{1}{2}$ miles off.

From San Antonio point the coast trends about east for $2 \frac{1}{4}$ miles, and is of a rocky formation, with many outlying rocks both above and below water.

Las Tetas de Cabra are two remarkable peaks 1,633 feet high, situated about $\frac{1}{2}$ miles to the eastward of San Antonio point and less than $\frac{1}{2}$ mile back of the beach. They resemble, as their name implies, a goat's teats, and are a valuable landmark in making the port of Guaymas.

Doble point, $2 \frac{1}{4}$ miles east of San Antonio point, is a headland from 200 to 300 feet in height, and of an average width of 300 yards; it projects to the southward from the general coast line nearly a mile. The southern extremity of this headland, which is 50 feet high, is called Doble point.

On the west side of the headland, where it joins the coast, is a small open bay with a sandy shore, known as the ensenada de las Tetas.

San Guillermo point is a rocky point projecting from the east side of the headland just mentioned. A number of detached rocks lie off the point, and about halfway between it and Doble point is a rock 150 feet high, known as Santa Catalina island. 
Paredones point, is a bluff point situated at the eastern side of the entrance to puerto San Carlos. The extremity of the point is 600 yards north of 'San Guillermo point and 300 yards east of the nearest part of the headland of which Doble point is the southern extremity.

Puerto San Carlos is a small landlocked harbor which affords an excellent anchorage, with perfect shelter, for small vessels. The entrance, which is between Paredones point and the headland mentioned above, is only 200 yards in width at its narrowest part, with from 4 to 8 fathoms of water. Inside, the width of the harbor increases to $\frac{1}{4}$ mile, the water shoaling gradually toward its head, 3 fathoms being found 800 yards from the narrowest part of the entrance.

San Nicolas island is a small islet about 50 feet high, and surrounded by detached rocks. It lies a scant $\frac{1}{2}$ mile eastward of San Guillermo point, and about the same distance from the nearest land to the northward. In the channel between it and San Guillermo point there are from 9 to 11 fathoms of water.

The passage between it and the mainland to the northward is considered dangerous, being full of rocks and islets.

Punta de las Cuevas is a sharp bluff point, situated $\frac{1}{2}$ mile eastward of Paradones point. Between the two points and San Nicolas island are some outlying rocks and islets, making the channel dangerous, as mentioned above.

Ensenada San Francisco is a large open bay formed by a sweep to the northward of the coast line east of punta de las Cuevas. The shore in the western portion of the ensenada is hilly, in the eastern portion of the north shore it is low and sandy, the lowland extending well into the interior. The eastern shore is for the most part rocky, with bluffs, high land rising immediately back.

An extensive lagoon known as the estero Soldado opens into the northeastern part of the bay, and there are several islets and rocks within its limits.

Chapetona lies in the northwestern part of the ensenada de San Francisco, and is a barren islet about $\frac{1}{4}$ mile long and 40 feet high, with steep bluffy. shores and numerous outlying rocks.

Medio and Candelero islands, in the eastern part of the ensenada, are respectively 20 and 35 feet high. About 200 yards north of Medio is a detached rock 40 feet high, and about the same distance north of Candelero is one 8 feet high, between which and Medio is a channel nearly $\frac{1}{2}$ mile wide and apparently free from dangers. All three of these islands are surrounded by outlying rocks close to.

Ensenada de Bocochibampo is an open bay a little more than a mile in extent either way, lying north of Colorado point. There is from 8 to 10 
fathoms of water at the outer limit of the bay, decreasing rapidly toward the head.

Good anchorage may be had in 4 or 5 fathoms, $\frac{1}{2}$ mile from the beach in the northeastern part of the bay.

Just back of the eastern shore of the bay is a shallow lagoon, into which only boats can enter.

Supplies.-Fresh water, fresh beef, fruit, etc., may be obtained.

Cerro Bocochibampo (two peaks), 1,643 feet high, lies about a mile to the northward of the northern shore of the ensenada of the same name.

Colorado point is a prominent headland 60 feet high, connected with the mainland by a low, narrow strip of sand beach. Off its southern side are numerous detached rocks.

Blanca island, lying about 300 yards to the northwestward of Colorado point, is about 230 yards long and 100 feet high.

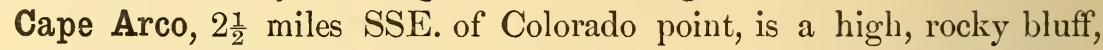
with a hill 862 feet high rising abruptly back of it. About half way between the points, a little nearer cape Arco and $\frac{1}{4}$ mile from the nearest shore, is a solitary rock 30 feet high.

Lobos island is a large rock 125 feet high, lying 400 yards to the northwestward of cape Arco and close to the shore. From 600 to 1,000 yards northward of Lobos island is a group of rocks lying a short distance off the land, some of which are from 30 to 40 feet high.

Mesquite point, which is 250 feet high, is a little more than $1 \frac{1}{4}$ miles eastward of cape Arco.

Ensenada Carisel.--Between cape Arco and Mesquite point there is a deep bight, known as ensenada Carisel. It is entirely open to the southward and has a short strip of sand beach in its most northern part. Part of its northern shore is of rocky bluffs, with outlying rocks.

San Rafael point is a rocky, bluff point, situated about midway between Mesquite point and cape Haro. Mount San Rafael, 1,200 feet high, bears N. $25^{\circ}$ E. (N. $14^{\circ}$ E. mag.) from it, distant about a mile.

Cape Haro is the southern extremity of the peninsula upon which Guaymas is situated.

It is a prominent, rocky headland, surmounted on its western end by a bold hill 365 feet high, and may be closely approached, upwards of 20 fathoms of water being found within 200 yards of it.

Light.-On the south extremity of the eastern part of the cape is a lighthouse from which, at an elevation of 345 feet, is shown a fixed light flashing every half minute. It is visible 24 miles.

Currents.-There are many conflicting reports regarding the strength and direction of the currents off this part of the coast, but it is evident that they depend greatly, if not entirely, on the force and direction of the wind. 
Narisson point, the first prominent point north of cape Haro, is 1,000 yards distant from it, and is composed of high, rocky bluffs.

Catalina bay is a small cove, open to the eastward, the entrance being between Maria and Ventana points, the former of which is a little more than $\frac{1}{2}$ mile north of Narisson point. The soundings in the bay are regular, varying from 3 fathoms near the shore at its head, to 8 and 10 fathoms at the entrance.

San Vicente island, formerly known as Trinidad, is the western point of the entrance to the harbor of Guaymas. It is separated from Paz point on the mainland by a channel 100 yards wide, through which $2 \frac{1}{2}$ fathoms of water may be carried. The name Trinidad was probably given to this island from the fact that, in connection with a large outlying rock to the northward, it appears from a short distance like three separate islands.

Pitahaya island, lying just north of Paz point, is high, rocky, and of small extent. The channel between it and the point is a little over 200 yards in width, with from 2 to 3 fathoms of water. On the mainland to the westward of Pitahaya is a small stream emptying into the bay. It is. said that fresh water may be obtained a short distance up this stream.

Pajaros is a long rocky island, the highest point of which is 212 feet high. It forms the eastern side of the entrance to Guaymas harbor, the channel between it and San Vicente being 1,600 yards in width, with 6 fathoms of water. From its SW. extremity a rocky reef makes off a short distance to the northward, and a similar one makes off from its NE. extreme.

Guaymas harbor may be considered as divided into two parts-an outer harbor for vessels of 20 or 22 feet draft, and an inner one for vessels of not over 15 feet draft. The outer harbor occupies a space inclosed between punta Baja and morro Ingles on the east, and the islands of Almagre Grande and Ardilla on the west. The inner harbor lies inside of Almagre Chico and the islands just mentioned, between them and the mainland.

Punta Baja lies about $\frac{7}{8}$ mile to the northwestward of the SW. extremity of Pajaros island, the channel between having a depth of from $5 \frac{1}{2}$ to 7 fathoms. It is a rocky bluff point with some outlying rocks close to; back of it the land rises gradually.

Morro Ingles is a solitary rocky hill situated at the western extremity of a long, low, narrow strip of sand beach, known as the playa de las Dolores. It bears N. $11^{\circ} \mathrm{E}$. (North mag.) from punta Baja, and is $\frac{3}{4}$ mile distant from it, the navigable channel between them being $\frac{1}{2}$ mile wide, with a depth of from 3 fathoms near the shore on either side to $5 \frac{1}{2}$ and 6 fathoms in the middle. A shoal, which is partly bare at low water, extends 600 yards westward from the morro Ingles. 
Boca Chica.-Between Pajaros island and the playa de las Dolores is a passage through which 12 feet can be carried. This passage is known as the boca Chica.

Anchorage.-The best anchorage for large vessels is on or just inside of a line between the highest points of Almagre Grande and morro Ingles, in $3 \frac{1}{2}$ to 4 fathoms of water, where good holding ground will be found, with protection from every wind. Smaller vessels having a draft of not over 13 feet may proceed farther in, passing between Almagre Grande and Ardilla, and anchor in $2 \frac{1}{2}$ to $2 \frac{3}{4}$ fathoms, $\frac{1}{2}$ mile from the landing place. The inner anchorage is perfectly landlocked. Vessels of over 22 feet draft should anchor between Pajaros island and punta Baja, in 6 fathoms of water.

Directions.-The land in the vicinity of Guaymas having been once seen can not, with ordinary care, be mistaken. Cape Haro and Las Tetas de Cabra are probably the best landmarks and are not easily mistaken even by an entire stranger.

It is advisable to make the land to windward of cape Haro (the prevailing wind being from the NW.), keeping it under the lee until close in, when it may be 'rounded close to, deep water extending close up to the rocks. After rounding cape Haro the entrance between San Vicente and Pajaros islands will be readily distinguished. Steer so as to leave Pajaros on the starboard hand, giving the points on either side a berth of 200 yards. After passing punta Baja, being in about 6 fathoms of water, steer for the fort on the eastern end of Ardilla islands and anchor in 4 fathoms, about on a line between the highest parts of morro Ingles and Almagre Grande. The lead is a safe guide in entering, and after passing the south western end of Pajaros island must be kept going, to avoid getting in the shoal water on the east side of the channel. With a leading wind this shoal may be easily avoided by keeping well over toward punta Baja. In beating in care must be taken not only on account of the shoal just mentioned, which may easily be avoided by a proper use of the lead, but also to avoid the shoal (which partly uncovers at low water), lying off morro Ingles.

To avoid this last shoal, do not bring the fort on the east end of A rdilla to bear anything to the westward of N. $57^{\circ} \mathrm{W}$. (N. $68^{\circ} \mathrm{W}$. mag.) or do not open the cemetery that is situated in the eastern outskirts of the town, east of the fort. Wishing to enter the inner harbor, if with a leading wind or a steamer, steer from the outer anchorage toward the highest part of Ardilla until on a line between morro Ingles and the white fort on Cantara point, then steer for the latter (passing between Almagre Grande and Ardilla), until clear of the islands, when haul up for the center of the town and anchor as soon as well clear of the passage; or, if desirable, stand in as far as the vessel's draft will permit. The soundings decrease regularly from the passage between the islands toward the shore. With a head wind the 
eye and lead are safe guides, care being taken not to approach the shores. of the islands too closely. Tides rise about 4 feet.

Guaymas is surrounded.by high mountains, and is extremely hot in the rainy season. The fevers prevalent at San Blas and Mazatlan prevail here, but in a lesser degree. The population in January, 1885, was about 7,000 , most of whom were in a state of wretched poverty; the entire business of the place is monopolized by a few wealthy firms and individuals. There is a regularly appointed sanitary commission, a military and civil hospital, and a garrison of 250 men. A number of Yaqui Indians (about 500 ) occupy one section of the city. These Indians are very intelligent and possess considerable mechanical ingenuity. They are experts in saddlery and the manufacture of straw goods ; their earthenware is of good quality, and the serapees (shawls) which they weave by hand are unsurpassed for beauty and fineness of texture.

Within the city are a number of fine structures of the architecture peculiar to the country, and a few of the American style.

The United States is represented by a consul and vice-consul.

Climate.-The climate from November to April is pleasant, but the heat during the summer months, from June to September, is excessive, the mercury reaching $105^{\circ}$ to $110^{\circ}$, and seldom falling below $97^{\circ}$ or $98^{\circ}$. When the hot winds visit the town, as they often do in the summer months, it frequently reaches $135^{\circ}$.

Supplies.-Fresh water of an indifferent quality can be procured at a cost of $1 \frac{1}{2}$ to 2 cents per gallon. Excellent flour, fresh bread, and beef can be obtained in any quantity at moderate prices. Good oysters from the Yaqui river are found in the market at the proper season. No salt provisions or ship's stores can be purchased. At the time of the Narragansett's visit the Colorado Steam Navigation Company had a small amount of coal for steaming purposes.

The exports are wheat, corn, flour, cotton, tobacco, unrefined sugar, aguadiente, dried beef, hides, gold, silver, and copper.

The imports are the products of the more southern provinces, with East Indian and European manufactured goods.

The Sonora railroad connects Guaymas with the interior and California, giving daily communication. Real estate and mines have increased in value since this road commenced operations. The railroad has built a large hotel.

Steamers.-The California and Mexican Steamship line makes regular monthly voyages to this port from San Francisco. This company receives a subsidy from the Mexican Government of $\$ 2,000$ the round trip. The Mexican steamship line, called the Gulf of Cortez line, is supposed to make trips every 21 days, touching at Manzanillo, San Blas, La Paz,'Mazatlan, Altata, and Guaymas. It receives $\$ 1,500$ subsidy the round trip, 
but is not regular. The Mexican steamer Altata, of 60 tons, belongs to the Sinaloa and Durango Railroad Company, and makes monthly trips between Mazatlan and Guaymas, touching at Altata and Agiabampo.

The telegraph line is owned by the Mexican Government.

Mails.-There is a daily mail with the United States by rail and a monthly mail by sea to San Francisco, as well as one every fortnight to the coast ports south.

La Laguna is an extensive sheet of water lying to the northwârd of the outer anchorage of Guaymas and the playa de las Dolores, with an average depth of 2 fathoms in its southern part. The northern part is full of shoals and sand bars, with a narrow channel, in which there is from 6 to 8 feet of water, extending as far as Blanco point, which is $2 \frac{1}{2}$ miles nearly north of morro Ingles. At Blanco point a sand spit moves off to the eastward $\frac{1}{2}$ mile, nearly joining one making off the same distance from the opposite shore, the channel between them being less than 100 yards in width. Northward of this, La Laguna is, with the exception of a few narrow boat channels, dry at low-water springs. A fresh-water stream, known as the estero del Rancho, empties into La Laguna a short distance northwestward of Blanco point.

San Jose de Guaymas lies on both sides of the estero del Rancho, $1 \frac{1}{2}$ miles from its mouth. It is inhabited by civilized Indians of the Yaqui. tribe. The country in the vicinity and far into the interior is level and sandy.

Hermosillo is the principal town in this part of Sonora. It is situated north of Guaymas, distant from it by the road 84 (statute) miles, and lies in a gap which the rio Sonora has cut through the western range, surrounded by high hills. It has a population of about 15,000, and is the center of an important silver-mining region. There is a mint for coining silver dollars. Cotton goods and brandy are manufactured to some extent. Maize, cotton, and fruit are exported by way of Guaymas, which is its seaport.

Coast.-From morro Ingles the coast trends nearly east for a distance of 12 miles, to another conical hill, 379 feet high, known as cerro Yacicoris. This part of the coast, which is a smooth sand beach, is called El Cochore.

Two and a quarter miles east of morro Ingles, separated from the waters of the gulf by a narow strip of sand beach, is a small lagoon, called estero Cochore, which has an opening into La Laguna. Three and a half miles further east is a deserted village in a conspicuous grove of palm trees, close to the beach.

Soundings obtained off this part of the coast show a less depth of water than is given on charts made from former surveys. Four and 5 fathoms only were found in places where the charts gave 6 and 7 fathoms. This 
would seem to indicate that the mud and sand brought down by freshets in the streams of this vicinity are deposited in the outer bay of Guaymas, and not carried off by the coast currents.

Cerro Tordillo.- A bout midway between morro Ingles and cerro Yacicoris is a bluff point, with a conspicuous hill a short distance back of it, known as cerro Tordillo.

Viego Yaqui.-Eastward of cerro Yacicoris is a deep indentation in the coast line, filled with shoals and sand bars, and navigable only for boats. The river is known as Viejo Yaqui, or rio de Matape, which takes its rise in the Sierra Yaqui, and is dry during the greater part of the year, empties into this bay or indentation.

San Marcial, 60 miles up the rio de Matape, is the nearest place to Guaymas where coal is found, and in the future it may be of importance to the prosperity of that place. At present the difficulties of transportation are too great to make working the mines profitable.

Coast.-From cerro Yacicoris to Lobos point, a distance of 31 miles, the coast trends nearly south, and is low and sandy, being merely a strip of sand separating the waters of the gulf from the numerous lagoons that lie back of it. None of these lagoons are navigable except by boats or vessels drawing less than 6 feet of water. Sandy shoals extend off this part of the coast from $\frac{1}{2}$ mile to $1 \frac{1}{4}$ miles, with not more than 3 fathoms of water on their outer edge. Outside the shoals the soundings increase regularly until about 6 miles off and about on a line between cape Haro and Lobos point, when they increase suddenly from about 40 to 190 and 200 fathoms.

The Yaqui river is the largest stream in the province of Sonora, and is indeed the only one deserving the name of river. It rises in the mountains near the Arizona boundary, and flowing in a southerly direction empties into the gulf of California, about midway between cape Haro and Lobos point. The mouth of this river is filled with shoals and sand bars, and in the dry season it is navigable only by the smallest coasters. It has three outlets, which from a short distance appear like lagoons. A sand bank over 2 miles long and from $\frac{1}{4}$ to $\frac{1}{2}$ mile wide, over which the sea breaks, extends across its mouth, having passages at either end between it and the shoals.

Coal.-There are said to be extensive fields of an excellent quality of coal on both sides of the Upper Yaqui, which may give it some importance in the future.

Currents; fogs.-Strong currents, variable in direction, are often encountered in this vicinity, and fogs are of frequent occurrence.

Baroyeca mountain, which lies 50 miles S. $85^{\circ}$ E. (N. $84^{\circ}$ E. mag.) from the center of the sand bar, off the entrance to the Yaqui river, affords a good landmark. It is 3,298 feet high. 
Lobos point, at the northwestern extreme of Lobos island, is low and sandy, with a dangerous shoal making off nearly $2 \frac{1}{2}$ miles to the northwestward. At the outer edge of this shoal from 5 to 7 fathoms of water were found, the soundings increasing within less than $\frac{1}{10}$ mile to 95 fathoms and over; bottom of fine, dark sand. Southward of the point vessels may anchor in good weather in 6 fathoms, $\frac{1}{2}$ mile from the shore.

Lobos island is low and sandy, $4 \frac{1}{2}$ miles long, nearly ESE. and WNW., and about $1 \frac{1}{2}$ miles wide. It is separated from the mainland by the estero de la Luna, which has openings to the gulf on its north and east sides. The highest part of the island is a remarkable green mound, monte Verde, 75 feet high, situated about $1 \frac{1}{2}$ miles eastward of Lobos point. Between the hill and the point is a solitary palm tree, which serves as a landmark for the coasters.

Coast.-The coast from Lobos point to the northwestern end of Ciaris island, a distance of 42 miles, trends SE. by E. $\frac{1}{4} \mathrm{E}$., and has the same general character as above the point, viz, low, sandy, covered with bushes, and cut up by lagoons, off the entrances to which shoal water extends from one to 2 miles. The soundings 3 miles off shore show a depth of from 6 to 10 fathoms.

About midway between Lobos and Ciaris islands is the former mouth of the rio Mayo, Viejo Mayo, off which there is a bar, over which the sea breaks.

Eight miles northwestward of Ciaris island and about a mile off the entrance to a lagoon is a small sand island 3 feet above the level of the water. At this point shoal water extends over 2 miles off shore.

Ciaris island is similar in appearance to Lobos island, and can only be distinguished from it by the absence of the solitary palm tree. It is a little over 12 miles long, parallel with the coast, and from $\frac{1}{2}$ mile to a mile in width. It is separated from the mainland by a narrow estero of the same name, the entrance to which, at the the northwestern end of the island, is over $1 \frac{1}{2}$ miles wide, but shoal, with heavy breakers clear across it.

Just west of the NW. point of Ciaris is a low, sand islet a mile long and about 2 feet above water. A shoal makes out to the westward from it over $1 \frac{1}{2}$ miles.

Anchorage.-Vessels may anchor anywhere along the coast between Lobos point and Ciaris island, in fine weather, taking care not to approach the land within 3 miles, or to get in less than 6 fathoms of water.

Alamos peak is a conspicuous sharp mountain, 5,877 feet high, bearing S. $88^{\circ}$ E. (N. $81^{\circ}$ E. mag.) 51 miles distant from the north point of Ciaris island.

Arboleda point is an indefinite rounding point situated $13 \frac{1}{2}$ miles to the southeastward of the NW. point of Ciaris island, on an island $2 \frac{3}{4}$ miles long in a north, and south direction, and something more than $\frac{1}{2}$ mile wide, 
separated from the mainland by the continuation of Ciaris estero. There are some clumps of scrubby trees on this island which serve as an excellent landmark for the coasters, being the only ones in the vicinity.

Coast.-From Arboleda point the coast trends somewhat more to the eastward. Four and a half miles to the southeastward of the point is the narrow entrance to the estero de Santa Lugada, which is of considerable extent. There is a bar with very shoal water at the entrance.

From the entrance of the estero to punta Rosa the coast is a bare sand beach with a few bushes, and back of the beach is a series of yellowish sand hills from 50 to 85 feet high.

Punta Rosa is a low, reddish point. From here the coast turns sharply to the northeastward for about a mile, and then trends nearly east for $8 \frac{1}{2}$ miles, to the mouth of the rio Mayo. The bight just east of the point is known as Santa Barbara bay.

Santa Barbara bay affords an excellent anchorage in NW. winds, but is entirely open to southeasters. The best anchorage is about a mile east of the point, and the same distance off shore, in about 7 or 8 fathoms of water.

A customhouse has been established in the bay, and is situated where, on H. O. chart 620 , huts are marked.

The country in this vicinity is well watered, fertile, and quite thickly populated. There are several fresh-water lakes or ponds in the vicinity, and a small stream empties into Santa Barbara bay. Game is very abundant, large numbers of deer, rabbits, wild geese, and ducks were seen. The Indian villages of Vacamora and Santa Cruz, the latter on the right bank of the rio Mayo, lie about 4 miles to the northward of the north shore of the bay.

Rio Mayo.-The entrance to the rio Mayo lies about $9 \frac{1}{2}$ miles east of punta Rosa. It, like all the rivers on this coast, is closed by a bar, leaving a narrow channel on the eastern side through which 2 fathoms may be carried in the dry season. The entrance, which is a mile wide, may be recognized by a bare sand mound 85 feet high on its western side, and a mound 75 feet high, on which there is some vegetation, on the eastern side. Shoal water extends off it for nearly 2 miles.

Just inside of the entrance, on the eastern side, is a snug little cove where small vessels may anchor in 3 fathoms of water and be well sheltered from every wind.

Coast.-The coast from the eastern point of entrance to the rio Mayo trends about ESE. for a distance of about 9 miles, to an Indian village near the shore, thence to the main entrance to the estero de Agiabampo, a distance of 16 miles, it trends nearly south, and is throughout the entire distance low, sandy, covered with bushes and cut up by lagoons. 
The estero de Agiabampo is an extensive lagoon, the entrance to which is narrow and intricate, being obstructed by shoals and sand bars, which extend about a mile off from the general coast line. 'The least depth found in the channnel at low water was 2 fathoms. On either side were shoal patches, with from 3 to 5 feet of water, over which the sea broke heavily.

The bar and channels are undoubtedly subject to change, and the greatest care is necessary. The best time to enter the estero is with the first of the sea breeze. The best anchorage outside the estero is in 7 fathoms, $1 \frac{3}{4}$ miles off shore. Tides rise about 4 feet.

Agiabampo is situated on the north shore of the estero, about 101 miles from the bar. It is a place of some importance, being the seaport of the cities of Alamo (40 miles distant) and Fuerte (45 miles distant), with both of which it is connected by roads. It has a customhouse, and exports treasure, silver ore, and dyewood.

Coast.-The coast south of the estero de Agiabampo trends about SSW. $\frac{1}{4} \mathrm{~W}$., to the outer edge of the shoal off the mouth rio del Fuerte, a distance of $22 \frac{1}{2}$ miles. It is similar in character to that north of Agiabampo, being low, sandy, and, that part of it lying south of the Alamos river, cut up by lagoons.

Alamos river.-The mouth of the Alamos river, which is narrow and has shoal water extending off from it $\frac{1}{4}$ mile, lies $10 \frac{1}{2}$ miles to the southward of the cross on the south side of the entrance to the estero de Agiabampo. It is navigable only for the smallest coasters. The sea breaks almost continually over the bar at its mouth.

The rio del Fuerte, or Santa IMaria de Ahome, forms part of the boundary line between the provinces of Sonora and Sinaloa. The entrance, which, like that of all the rivers along this coast, has a bar extending across it, lies 12 miles to the southward of that of the river Alamos.

Fronting the mouth of the river is a sand island a mile long and $\frac{1}{2}$ mile wide; at either end of the island are shallow channels leading into the river, which are navigable only by the small coasters. Two or three miles up the river, on either bank, are thick clumps of green trees and bushes. The village of Ahome is on the left bank of the river, about 10 miles from its mouth, and the town of El Fuerte, in an important mining region, is about 75 miles from the mouth of the river.

During the rainy season the river is swollen considerably, and large quantities of dyewood are floated down in rafts or on flatboats.

Ahome point is the north point of entrance to the river just described and is a low sand point projecting over a mile from the general coast line. An extensive shoal, over which the sea breaks, extends off from.it in all directions from one to $1 \frac{1}{2}$ miles.

Alligator hill.-Alligator hill is a remarkable flat-topped hill situated 6 miles N. $45^{\circ}$ E. (N. $34^{\circ}$ E. mag.) of Ahome point and is a good landmark. 
Eastward of Alligator hill and about 118 miles from the coast is the sierra de San Pablo, 2,026 feet high.

Lagoon.-A lagoon, lying parallel to the coast and having two shallow openings to the gulf, extends 8 or 9 miles northward from rio del Fuerte.

Coast.-From rio del Fuerte to San Ignacio point a distance of 19 miles the coast trends about south, and is low and sandy, consisting of a series of islands, on which are some low sand hills and a scanty growth of bushes. The islands are separated from the mainland by lagoons that lie parallel to the coast.

Estero de las Piedras is the northernmost of the two entrances to the lagoons lying between rio del Fuerte and San Ignacio point. It is about $\frac{1}{2}$ mile in width and has a narrow bar extending a short distance off, over which the sea breaks. The bar is 6 miles south of the sand island off the the entrance to the rio del Fuerte.

Lechuguia.-The island of Lechuguia lies south of the estero de las Piedras. It is $8 \frac{1}{2}$ miles long and from one to 2 miles wide, with a ridge of sand hills from 25 to 50 feet high and some scattered bushes. At its southern end is an entrance to the lagoons, known as Lechuguia estero, which is $1 \frac{1}{4}$ miles wide, and has an island a mile long and $\frac{1}{4}$ mile wide in its outer part.

Off Lechuguia estero and extending around San Ignacio point is a dangerous shoal, over which the sea breaks heavily. Soundings of $5 \frac{1}{2}$ fathoms were obtained $4 \frac{1}{2}$ miles N. $62^{\circ}$ W. (N. $73^{\circ}$ W. mag.) of San Ignacio point, the depth increasing suddenly to 60 and 100 fathoms a short distance to the southwestward.

Directions. - To clear this shoal, keep the Farallon de San Ignacio on a bearing to the eastward of S. $15^{\circ}$ E. (S. $26^{\circ}$ E. mag.). When the southern and highest peak of the sierra de San Pablo bears N. $50^{\circ}$ E. (N. $39^{\circ}$ E. mag.) you are to the north ward of the shoal.

San Ignacio point is a low, sandy point at the southern end of a small sand island, which lies off the western end of Santa Maria island, separated from it by a narrow shoal channel.

San Ignacio bay.-From San Ignacio point the coast turns sharply to the northward for about 2 miles and then curves around to the southeastern point of Santa Maria island, known as Santa Maria point, forming the open bay of San Ignacio.

There is good anchorage in San Iguacio bay in 5 or 6 fathoms of water, from $\frac{1}{2}$ mile to a mile from the northern shore, with protection from the northwesterly winds, but is entirely open to winds from the southward.

Santa Maria island, which forms the north shore of San Ignacio bay, is a sandy island $13 \frac{1}{2}$ miles long, with an average width of about a mile. It has a steep beach, with a range of sand hills from 50 to 100 feet high $11562-8$ 
back of it, and a scanty growth of bushes. It is separated from the mainland by a lagoon.

Santa Maria point, the southeastern extreme of the island of the same name, is the northern point of the entrance to Topolobampo harbor.

Farallon de San Ignacio.-The Farallon de San Ignacio is the best landmark for making the entrance to Topolobampo harbor. It lies 131 miles S. $60^{\circ} \mathrm{W}$. (S. $49^{\circ} \mathrm{W}$. mag.) from Santa Maria point, and is a small barren rock of a whitish color (from a deposit of guano), about $\frac{1}{3}$ mile in extent either way, and 465 feet high. There is deep water close to on all sides of it except the northern, where there are a few outlying rocks close to.

Topolobampo harbor.- The entrance to Topolobampo harbor is between two lines of breakers, and is exceedingly narrow and intricate. The bar is $2 \frac{1}{4}$ miles from the nearest land (Santa Maria point), and is less than $\frac{1}{2}$ mile wide at its deepest part, with from $2 \frac{1}{2}$ to $2 \frac{3}{4}$ fathoms of water on it at low tide. Inside the bar the depth of water in the channel increases gradually until abreast of Sand island, where 10 to 12 fathoms are found.

Sand island is one mile distant from Santa Maria point, and may be considered the southern point of the entrance, although Shell point is the first point of the mainland, on the south side of the entrance. A little over $\frac{1}{2}$ mile to the westward of Sand island, on the opposite side of the channel, there is an isolated shoal which is just bare at low water. After passing Sand island the channel, which averages something less than $\frac{1}{2}$ mile in width, leads to the eastward for about 3 miles, having a depth of from 5 to 8 fathoms, sandy bottom, and then takes a northeasterly direction, passing close to the rocky heads that project from the mainland on its southeastern side. Toward the northeastern limit of the harbor the channel narrows to a width of about $\frac{1}{4}$ mile and deepens considerably, 15 and 16 fathoms being found in it. After passing a high headland, surmounted by a hill 817 feet high, known as mount San Carlos, it enters a large bay called San Carlos bay.

The channel is the only part of Topolobampo harbor that is navigable for vessels of any size, the other parts of it being very shallow and full of shoals.

Anchorage.-There is excellent anchorage inside the shoals in 7 or 8 fathoms, sheltered from every wind. The best anchorage outside the bar, which is safe only in moderate weather, is in 8 or 10 fathoms of water, with Round hill, a conspicuous sharp hill on the northern shore of the harbor, bearing N. $45^{\circ}$ E. (N. $34^{\circ}$ E. mag.). The nearest breakers will then be $\frac{1}{2}$ mile to the eastward.

Directions.-The following directions will be found of service in entering the harbor of Topolobampo, but should not be too much relied on, as the channel and shoals, from the bar to Shell point, are constantly chang- 
ing, and no vessel of over 12 feet draft should attempt to enter without first sounding and marking the channel. When off the bar, bring Round hill (251 feet high), on the northern shore of the harbor, to bear $\mathrm{N}$. $45^{\circ}$ E. (N. $34^{\circ}$ E. mag.) -and steer for it, keeping it on that bearing, but taking care as Sand island is approached, not to shut in the spur, shown to the left of the northwestern slope of the table mountain in the view, until well past the island. To avoid shutting in the spur it is necessary to steer a more northerly course, bringing Round hill on the starboard bow. Be careful not to approach Sand island too closely, as a shoal extends off from it a short distance to the northward and eastward. When Santa Maria point bears N. $81^{\circ} \mathrm{W}$. (S. $88^{\circ} \mathrm{W}$. mag.) Round hill bearing about N. $50^{\circ}$ E. (N. $39^{\circ}$ E. mag.), change the course to the eastward, heading for the first rocky bluff point eastward of Shell point about N. $88^{\circ} \mathrm{E}$. (N. $77^{\circ}$ E. mag.), and after proceeding $\frac{3}{4}$ mile in this direction, anchor anywhere in the channel. If it is desirable to proceed farther in, continue on the same course until mount San Carlos bears N. $53^{\circ}$ E. (N. $42^{\circ}$ E. mag.), then steer for it, remembering that the deepest water is on the SE. side of the channel, and that the projecting points on that side may be approached to within a short distance. As mount San Carlos is. approached, steer for the middle of the passage between it and the island on the opposite side of the channel. The water is deep close to the headland on which mount San Carlos is situated.

The bar and shoals near the entrance appear to have changed considerably since 1869 , at which time a survey was made by the U. S. S. Jamestown, Commander W. T. Truxton, commanding.

In ordinary weather the sea breaks in $1 \frac{1}{2}$ fathoms, but with fresh southerly or westerly winds' it breaks entirely across the bar.

Currents. - The tidal currents on the bar and in the channel are strong, and care is required to keep on the ranges.

Remarks. - It is said that fresh water may be obtained by sinking wells in the sand near Shell point. Fish and turtle are abundant in the waters in the vicinity, and game is said to be plentiful in the interior. The vegetation in the vicinity of the harbor is very scanty.

San Carlos bay is large and lies to the northeastward of Topolobampo harbor, being connected with it by a narrow strait or channel. It has never been surveyed, but is known to extend 9 or 10 miles in a northeasterly direction and to have a width of from 4 to 6 miles.

After rounding the high headland on which mount San Carlos is situated, a narrow, intricate channel, with a gradually decreasing depth of water, was followed for about $3 \frac{1}{2}$ miles in a northeasterly direction. At that distance 3 fathoms were found. On either side of the channel the soundings were irregular, varying from 3 feet to 3 fathoms, with numerous sand bars and a few småll islands. 
Coast.-The coast from Topolobampo bar has a general trend ESE. as far as the mouth of the Sinaloa river, a distance of $41 \frac{1}{2}$ miles, and is, with the exception of the highland near Topolobampo entrance, low and sandy, being composed of a series of sand islands, separated from the mainland by lagoons. Four miles to the southeastward of Shell point the high land approaches the coast in bluffs from 20 to 50 feet in height, a sharp hill 765 feet high rising immediately back of them. Four miles farther on is an entrance to the extensive lagoon that lies parallel to the coast extending to and joining the Sinaloa river. Off this entrance is an extensive shoal, over which the sea breaks. The outer edge of this shoal, on which there is 3 fathoms of water, is $2 \frac{1}{2}$ miles from the land.

San Ignacio island is the westernmost of the series of islands before mentioned as forming the coast line between Topolobampo and the Sinaloa river. It is $12 \frac{3}{4}$ miles in extent from the lagoon entrance just mentioned, to Navachista estero, and from $\frac{3}{4}$ mile to $1 \frac{1}{2}$ miles in width. Back of the lagoon that separates it from the mainland, the peaks of the sierra de Navachista rise to a height of over 1,000 feet. In the northern part of the lagoon, nearly opposite the center of San Ignacio island, is a remarkable white rock 75 feet high.

Navachista estero.-The entrance to Navachista estero lies between the eastern end of San Ignacio island and the island of Vinorama. It is narrow and intricate, with about 2 fathoms on the bar at low water. The outer edge of the bar, which is $\frac{1}{4}$ mile wide in its narrorvest and deepest part, lies $1 \frac{3}{4}$ miles from the nearest land; and just west of the channel, the shoals extend 2 miles off the land, the sea breaking over them continually. Inside the bar the depth of water is from 5 to 7 fathoms.

Previous to 1875 the entrance to Navachista estero had been gradually shoaling and becoming more intricate, and the town of Navachista, some distance in the interior, was, in consequence, fast becoming depopulated, its rival, Playa Colorado, about 24 miles to the southeastward, increasing to a corresponding extent.'

Vinorama is a low, sandy island about $1 \frac{1}{2}$ miles in length and $\frac{3}{4}$ mile wide. On it are several cotton farms or ranches, and tolerably good fresh water may be obtained by sinking wells.

Boca Macapule lies to the eastward of Vinorama, between it and Macapule island. It is narrow and shallow, the shoal water extending about a mile off shore.

Macapule island, lying eastward of the boca Macapule, is 11 miles in length, parallel to the coast, and about a mile wide, a lagoon or estero of the same name separating it from the mainland. Its southern beach is nearly straight, and is free from shoals, having from 3 to 5 fathoms of water close to. At its eastern end is a small island, on either side of which is a narrow opening to the estero. 
The Sinaloa river empties into the gulf on either side of a small island covered with trees, the center of which is $4 \frac{3}{4}$ miles from the eastern end of Macapule island; is useless for the purposes of navigation. A shoal makes off about $\frac{1}{2}$ mile from the island at its mouth, and the discolored water from the river is very marked for some distance.

The old town of Sinaloa, built on a hill, is situated on the bank of the river, about 40 miles from its mouth. It was formerly of some importance, but it is now almost deserted.

The entrance to Playa Colorado estero is $7 \frac{1}{2}$ miles to the southeastward of the island, at the mouth of the Sinaloa river. Off it are extensive shoals, over which the sea breaks even in moderate weather. The depth of water on the bar is said to vary with the seasons, 9 feet being found at low water during the dry and 12 feet during the rainy season. As the bar is shifting, no directions that will hold good at all times can be given, and the only safe way is to sound out and mark the channel before attempting to enter. The deep water lies between the lines of breakers and they are the best guides. Inside the bar the breakers are the best guide.

Saliaca island lies to the eastward of the entrance to Playa Colorado estero. It is $3 \frac{3}{4}$ miles long $\mathrm{NW}$. and SE., about a mile wide, low, sandy, and covered with a scanty growth of bushes. An estero of the same name separates it from the mainland.

Playa Colorado.-The village of Playa Colorado, containing about 200 inhabitants, is situated 4 or 5 miles from the mouth of the estero of the same name.

Large quantities of dyewood are annually shipped from here.

Coast.-From the western end of Saliaca island the coast assumes a more southerly trend, the entrance to Altata estero being $39 \frac{1}{2}$ miles distant. Throughout this entire distance the shore is low and dangerous to approach, as it can not be seen at night before striking on the shoals that make off from many parts of it. The lead should be used freely, as the soundings are an excellent guide, and it is recommended not to get in less than 13 or 15 fathoms of water when navigating this part of the coast at night.

Altamura island lies eastward of Saliaca island, separated from it by a shallow opening to the esteros lying between them and the mainland. Shoal water extends off this opening for a distance of nearly 2 miles.

The island is 24 miles long in a direction parallel to the coast, and from $1 \frac{1}{2}$ to $2 \frac{1}{2}$ miles wide. Like the other islands on this part of the coast, it is low and sandy, with some sand hills and bushes.

Altamura point is a low indefinite point making out from the island of the sarne name, about 7 miles from its southeastern end. It is the northwestern limit of an extensive shoal which makes off 2 miles from the shore and extends 10 miles to the southeastward, across the mouth of Tule estero. 
Colorado point is the southern end of Altamura island and the northern point of the entrance to Tule estero, which lies between Altamura and Baredito islands. The shoal just mentioned as extending 10 miles southeastward from Altamura point extends clear across the entrance of Tule estero, the sea breaking heavily over it. At the time of the Narragansett's visit, in 1875, the wreck of the ship Mary Banks was lying in the breakers near Colorado point. The small town of Tule is situated on the bank of the Tule river, about 10 miles from the bar.

The Culiacan mountains, 2,000 feet high, in which the Tule river takes its rise, are about 25 miles to the eastward.

When off 'Tule estero, Agua Pepa peak, about 1,500 feet high, and the

- westernmost of three prominent peaks, will bear N. $42^{\circ}$ E. (N. $32^{\circ}$ E. mag.).

Baredito island, which is something in the form of a crescent, is about 10 miles long, with an average width of a little over $\frac{1}{2}$ mile. It forms the coast line between the entrance to Tule estero and that of Altata, and is separated from the mainland by a lagoon. Like Altamura, it is low and sandy, with a scanty growth of bushes and some low sand hills.

Shoals.-Off its southern part, a shoal on which there are heavy breakers makes out nearly 2 miles.

The entrance to Altata estero lies between the southeastern end of Baredito island and the northwestern end of a long narrow island. It is only about 200 yards in width at its narrowest part, and is marked on either side by lines of breakers.

The bar has between $2 \frac{1}{4}$ and $2 \frac{1}{2}$ fathoms on it at low water, but is shifting and subject to change.

A detached shoal, with a least depth of $1 \frac{1}{2}$ fathoms, lies on the south side of the channel leading over the bar. It is about a mile in extent NE. and SW., and $\frac{1}{2}$ mile wide, its inner edge 2 miles distant from the center of the passage between the two islands before mentioned. The sea breaks heavily over it.

Currents.-The tidal currents in the channel occasionally have a strength of 4 or 5 knots.

Anchorage.-The anchorage off Altata estero is in 6 fathoms of water, $3 \frac{1}{2}$ miles from the entrance, with El Dorado saddle in line with Double peak; bearing N. $56^{\circ}$ E. (N. $46^{\circ}$ E. mag.).

Altata, the seaport of Culiacan (the capital of Sinaloa), is situated near the mouth of the Culiacan river, which is reported to be navigable for a distance of 10 or 12 miles from its junction with Altata estero, having an average depth of about 5 fathoms; large quantities of dyewood are shipped from here.

Supplies.-There is but a poor supply of drinkable water to be obtained and provisions are scarce; cattle can be procured from a neighboring ranch. 
The Sinaloa and Durango railroad ends here. A small steamer, the Altata, belonging to the railroad, is employed in making trips between this place and Mazatlan, carrying bullion and passengers. It also makes regular trips to Guaymas. The Mexican steamer Alejandro makes semimonthly trips, touching at gulf ports Altata, San Blas, Chamela, and Manzanillo.

Coast.-From the entrance to Altata estero to the Piastla river, a distance of 87 miles S. $50^{\circ}$ E. (S. $60^{\circ}$ E. mag.), the coast is, with the exception of the boca Tavala, off which shoal water extends $1 \frac{1}{4}$ miles, an unbroken, almost straight line of sand beach, covered with bushes and free from outlying dangers, with from $4 \frac{1}{2}$ to 6 fathoms of water within $\frac{1}{2}$ mile of the beach. The low land stretches far away into the interior, and is backed by moderately high ranges of hills or mountains.

A narrow lagoon extends from Altata estero to a short distance southeastward of the boca Tavala, a strip of sand beach, from $\frac{1}{2}$ mile to a mile in width, separating it from the waters of the gulf.

Boca Tavala is a narrow outlet from the lagoon, probably caused by the rush of water from the rio Tavala or San Lorenzo, which empties into the lagoon a short distance to the northeastward. A shoal with 3 fathoms on its outer edge extends $1 \frac{1}{4}$ miles off the entrance. The anchorage is in 6 or 7 fathoms, 2 miles from the beach.

Rio Tavala or San Lorenzo.-During the dry season this river is only navigable for coasters drawing not more than 5 feet. On its right bank, about 15 miles from its mouth, is the small town of Quila, and 8 miles farther up, the town of San Lorenzo.

Elota river approaches the coast and, during the dry season, is lost in the sand $33 \frac{1}{2}$ miles $\mathrm{SE}$. of boca Tavala. It is a mere creek in the dry season, but during the rainy season becomes a turbid torrent. The village of Elota is situated on its right bank, about 20 miles from the coast, in a thinly populated and partially cultivated country.

Sierra de San Sebastian, with peaks from 1,000 to 5,000 feet high, lies from 15 to 25 miles back of the coast between the San Lorenzo and Elota rivers.

San Miguel point is a rocky point, with some close outlying rocks, situated about $5 \frac{1}{2}$ miles to the southeastward of the mouth of the Elota river. A short distance back of it is the northwestern limit of a range of remarkable hills, known as the cerros de Piastla, one of which, 920 feet high and of a triangular shape, called cerro de las Vigas, is $2 \frac{1}{2}$ miles $\mathrm{S}$. $69^{\circ}$ E. (S. $79^{\circ}$ E. mag.) from the point.

Four miles to the southeastward of San Miguel point is a rocky, bluff point of moderate height, with a mound 125 feet high immediately back of it. 
Piastla river.-The mouth of the Piastla river is 4 miles to the southeastward of the rocky, bluff point just described and 3 miles from Piastla point. Jike the Elota, it is a mere creek until the rains cunvert it into a torrent. Near the mouth of the river is a thick growth of trees and bushes, and good water may be obtained there.

The village of Piastla is about 20 miles up the river.

Piastla point is the southernmost of two rocky headlands lying about a mile apart, in a NNE. and SSW. direction. It is 156 feet high, and has a reef extending from it a short distance to the southward and westward.

Anchorage.-A sweep in the coast line between the mouth of the Piastla river and the northernmost of the two headlands forms a small bay or indentation, open to the northwestward, where vessels that come here for dyewood anchor, in 5 or 6 fathoms, about a mile from the shore.

Pier.-A short distance eastward of the extremity of the northernmost headland is a landing pier with some huts back of it. On a hill back of the pier is a signal pole.

Islet.-On a point between Piastla point and the mouth of the river of the same name, $\frac{1}{4}$ mile from the northernmost point before mentioned, is a white, rocky islet 35 feet high.

Supplies.--Drinkable water can be obtained at a short distance from the beach, from a lagoon, which is dry during the months of March, April, and May. Two wells sunk on the shore of this lagoon serve as cisterns or reservoirs. Not far from the landing place is a fertile plain, where cattle can be obtained.

Coast.-The coast south of Piastla point has the same general trend as that to the northward, and is for the most part low, sandy, and free from outlying dangers.

About $1 \frac{1}{4}$ miles southeastward of Piastla point there is a bluff 80 feet high, and 2 miles farther on is a shoal extending nearly $\frac{1}{2}$ mile off shore, over which the sea breaks.

Grueza point, $13 \frac{3}{4}$ miles southeastward of Piastla point, is a rocky bluff, surmounted by a hill 77 feet high. About midway between it and the shoal just mentioned is an arroyo, and $2 \frac{1}{2}$ miles southeastward of the point is another.

Roja point, about 5 miles below Grueza point, is a low, very slightly projecting, bluff point, with low land back of it.

Camaron point, a little more than 8 miles southeastward of Roja point, is a rocky bluff about 50 feet in height, with a hill, of reddish color, 403 feet high, 2 miles to the eastward.

Between Camaron point and the harbor of Mazatlan are several prominent islands and rocks, the former serving as landmarks in making Mazatlan. 
Pajaros island, the northernmost of the before-mentioned islands, is about $3 \frac{1}{2}$ miles southeastward of Camaron point and less than $\frac{1}{2}$ mile from the nearest point of the mainland (A renilla point). It is about 800 yards in extent each way and 467 feet high.

Anchorage.-Very good anchorage may be had on the north side of Pajaros island.

Anchor in 6 fathoms of water, with 30 fathoms of chain, swinging to not less than 5 fathoms, in a position with the SE. point of Pajaros island and the NW. point of Venado island just open.

Off the NW. point of Pajaros island, in line with the reef, uneven and foul bottom appears to extend a considerable distance. Rounding the point from the westward, a patch of 7 fathoms was found about $\frac{1}{2}$ mile from the point, dropping to 10 fathoms after passing it. About one mile off the point, in the same direction, a patch was seen breaking now and then, but, as the swell was heavy at the time, it is supposed that there is at least 7 fathoms over the patch.

Between Arenilla point and Mazatlan there are several lagoons, some of which are said to be of fresh water.

Venado island, a mile to the southward of Pajaros, is rather larger than the latter, but of the same character-rocky and barren. Its highest peak has an altitude of 587 feet.

The southern part of Venado is connected with the main body by a narrow neck of land called El Cuello. A detached rock, called Estrella rock, lies about 75 yards south of the southern extremity of the island.

The channel between Venado and the main land is a little over $\frac{1}{2}$ mile wide, and $2 \frac{1}{2}$ fathoms of water may be carried through it.

Shoal.-At $\frac{1}{2}$ mile N. $80^{\circ} \mathrm{W}$. (west mag.) from Peresil point the water is shoaler than shown on the charts, and it breaks with a moderate sea, while there is deeper water inside.

Creston island forms the western side of the outer harbor of Mazatlan. It is 800 yards in length, nearly north and south, about 400 yards wide and 470 feet high, with a short line consisting for the most part of steep, rocky bluffs. Within a mile to the northwestward of it are several islets and rocks, the most prominent of which are the north and south Hermano and Tortuga rock.

Light.-A fixed white light, visible about 20 miles, is shown from a square white tower, which rises from the center of a white building situated on the summit of Creston.

Azada island lies north of Creston, between it and Pala point, the southern extreme of the peninsula on which Mazatlan is situated. The channels on either side of it are not navigable by any except the smallest class of vessels; that on the south side is unsafe even for boats, being full of rocks. A new fort has been constructed on Pala point. 
Mazatlan harbor.-The available part of the harbor of Mazatlan is of small extent, and includes the space lying between the island of Creston on the west and Cicrvo on the east. It affords good protection from the northwesterly winds, but is entirely open to the southward, and is a dangerous anchorage for sailing vessels during the rainy season.

There is an inner harbor which can be used by vessels of 5 or 6 feet draft.

Ciervo island is similar in appearance to Creston and about half as high; it is partially covered with trees. Gama island, 160 feet high, lies 800 yards east of Ciervo.

Black rock is a small rock about 10 feet above water, over which the sea generally breaks. It lies just outside of Mazatlan harbor, on the following bearings, viz: Highest peak of Creston island, N. $34^{\circ} \mathrm{W} .\left(\mathrm{N} .44^{\circ}\right.$ W. mag.); highest peak of Ciervo, N. $17^{\circ}$ E. (N. $7^{\circ}$ E. mag.). The soundings in the vicinity of Black rock show from 12 to 14 fathoms close to it, shoaling gradually toward Creston and Ciervo islands and the anchorage between them.

Blossom rock is a dangerous pinnacle rock, with but 14 fathoms of water on it at low water. It lies in the outer part of the harbor, a little east of the best anchorage for large vessels, on the following bearings, viz: Signal station on hill north of Pala point N." $27^{\circ}$ W. (N. $37^{\circ}$ W. mag.); South bluff ${ }^{\circ}$ of Creston island west (S. $80^{\circ} \mathrm{W}$. mag.) ; Black rock S. $7^{\circ}$ W. (S. $3^{\circ}$ E. mag.). Blossom rock is generally marked with a flag buoy, but this mark should not be trusted, as it is frequently out of position. (Not in place 1892.)

A sure guide for clearing the rock is to keep monte Silla open to the westward of Ciervo island.

Monte Silla is a conspicuous saddle-shaped hill 256 feet high, situated on the point of the mainland, a little over $\frac{1}{2}$ mile northeastward of Ciervo island.

Anchorage.-A good berth is in 8 or 9 fathoms of water, with South bluff (Creston island) bearing S. $86^{\circ} \mathrm{W}$. (S. $76^{\circ} \mathrm{W}$.mag.) and the signal station on a hill northward of Pala point N. $16^{\circ} \mathrm{W}$. (N. $26^{\circ} \mathrm{W}$. mag.). To pick up this anchorage, when coming from the westward, pass the South bluff of Creston island at a distance of 100 yards, and steer. N. $77^{\circ}$ E. (N. $67^{\circ}$ E. mag.), heading for the highest part of Gama island; anchor when the signal station bears $\mathrm{N} .16^{\circ} \mathrm{W}$. (N. $26^{\circ} \mathrm{W}$. mag ). Black rock will then be just passing the beam, and bearing S. $11^{\circ} \mathrm{E}$. $\left(\mathrm{S} .21^{\circ} \mathrm{E}\right.$. mag.).

The town will come into view shortly before getting on these bearings.

Coming from the southward, pass west of Black rock, giving it a berth of 200 yards, and steer north (N. $10^{\circ}$ W. mag.) until South bluff (Cres- 
ton island) bears S. $86^{\circ}$ W. (S. $76^{\circ}$ W. mag.), when anchor, the other bearings being the same as before.

Caution.-It must always be remembered that monte Silla, open to the westward of Ciervo island, clears the Blossom rock. Should it be desirable to anchor nearer to the town, steer N. $13^{\circ}$ E. (N. $3^{\circ}$ E. mag.) from the anchorage just described and be guided by the lead; the soundings decrease regularly up to 15 feet.

During the bad weather season, September and October, it may be well to anchor farther out, or to the northwestward of Creston, where there is. more room for sailing vessels to get under way and, in the event of being obliged to do so, to stand out clear of the land.

Mazatlan-the official name of which is La Villa de los Castillos-is the only seaport of importance in the province of Sinaloa. It presents a picturesque appearance, the houses being light colored, and in the better part of the town handsome and commodious. It is considerably larger than Guaymas, having a population of about 16,000 , which varies with the seasons, being far greater in the dry season than during the rainy one. It is less unhealthy than San Blas, but severe fevers are common during the rạiny season.

It is the outlet for the products of the valuable mining districts of San Sebastian, and large quantities of English goods are imported directly from England. The trade is almost entirely in the hands of foreigners, who realize considerable profit from it. The city is well regulated, has a board of health, a civil and military hospital, several public schools, and a reading room organized by foreigners. Next to Acapulco it is the most important city on the Pacific coast between Panama and San Diego.

-It is proposed to make an artificial harbor by building breakwaters, docks, etc., and surveys are now being made to connect the harbor with the interior by a railway which will ultimately extend to connections with the American railway systems at Topeka.

It is reported that the marine railway, originally intended to be built at Acapulco, has been removed to Mazatlan.

The United States is represented by a consul and vice-consul.

Supplies.-Everything in the way of equipment or provisions that vessels require can be procured here. Fish, oysters, and turtle are plentiful. About 1,500 tons of coal are kept on hand, the price of which is $\$ 15$ per ton at the coal pile and $\$ 17.50$ per ton delivered alongside. It is bagged, and brought off in lighters towed by a tug. The coal pile is about $1 \frac{1}{2}$ miles from the anchorage. There are two large machine shops, where repairs to steamers may be made. Loaded vessels are taxed for the maintenance of the lighthouse; vessels entering in ballast are exempt. 
Landing.-In approaching the pier off the customhouse strangers should give the shore a good berth and pull for the end of the pier, as there are several sunken rocks lying a short distance off, on which boats would strike at half tide.

The inner or northern part of Mazatlan harbor is full of sand bars and shoals. It can only be used by vessels of the smallest class.

Pilots, harbor dues, etc.-Tonnage dues, $\$ 1$ per ton when loaded; if in ballast, none; bill of health, $\$ 4$; captain of the port, $\$ 4$; pilotage, $\$ 1.75$ per foot, and $\$ 5$ for a boat; customhouse papers, $\$ 25$ to $\$ 30$; ballast costs, $\$ 1.50$ for sand and $\$ 2$ for stone per ton; laborers, $\$ 2$ per day ; lighterage and landing cargo is at merchant's expense; costs from $\$ 1$ to $\$ 1.50$ per ton. Weights and measures are those of Spain. Pilotage not necessary, but compulsory.

Steamers.-The Pacific Mail steamers and the California and Mexican line call here once a month and the Mexican Steamship line every twentyone days.

There is telegraphic communication with the United States and South America.

The exports are dyewoods, fine pearls, gold, and silver.

The imports are mining machinery, fruits; vegetables are brought from San Francisco; cotton fabrics are brought from Europe.

Coast.-From Mazatlan to the Chamatla river, a distance of $32 \frac{1}{2}$ miles, the coast continues its southeasterly trend and is low and sandy, with a growth of bushes and stunted trees. There are no outlying dangers, the water deepening gradually from the shore to 10 or 12 fathoms at a distance of 2 miles from it.

Barron river empties into the gulf 10 miles to the southeastward of Mazatlan. It is only navigable in the dry season for small boats and canoes.

Metato peak, 3,000 feet high, situated near the left bank of the upper waters of the Barron river, bears N. $25^{\circ}$ E. (N. $15^{\circ}$ E. mag.), distant 15 miles from its mouth. It is the northernmost peak of a range of mountains lying 9 or 10 miles from the coast and is rather conspicuous.

Lagoon.-A narrow lagoon lying parallel to the coast and about a mile back of it, extends from the Barron to the Chamatla river, a distance of about 22 miles. The mountain range, before mentioned, also lies nearly parallel to the coast line, a few miles back of the lagoon. La Cabeza de Caballo, a remarkable peak 1,979 feet high, is nearly midway between the Barron and Chamatla rivers and about 8 miles from the coast.

Chamatla river, which like the Barron is only navigable in the dry season for small boats and canoes, has a shoal, on which there are less than 3 fathoms of water, extending $\frac{3}{4}$ mile off from its mouth, the sea generally breaking over it. On either side of the river, a short distance from its 
mouth, are some hills from 500 to 900 feet in height, known as the Chamatla hills.

The small towns of Chamatla and Rosario are situated on the banks of the river, a few miles from its moutl.

Anchorage. - The anchorage off the mouth of the Chamatla river is in 6 or 7 fathoms, about 2 miles from the shore, the northernmost and highest (3,738 feet high) of a mountain range, over 3,000 feet high, lying 18 or 20 miles from the coast, bearing N. $58^{\circ}$ E. (N. $49^{\circ}$ E. mag.), distant 21 miles.

It was from the little port at the mouth of the Chamatla that Cortez embarker, April 15, 1535, when he discovered California.

Coast.-The coast south of the Chamatla river is the same in character as that north of it, and as far as the boca Tecapan, a distance of 23 miles, has nearly the same general trend. Five miles to the southeastward of: the mouth of the Chamatla, where the hills approach the coast, is a deserted Indian village, close to the beach.

Boca Tecapan is the outlet of two quite extensive lagoons, into one of which (the northernmost) the Bayona river empties. A bar, the outer edge of which is nearly a mile off shore, extends $1 \frac{1}{4}$ miles on each side of the entrance, the sea breaking over it even in moderate weather. There are two channels leading into the estero, separated from each other by a shoal. In the northermost of these channels there is a depth of 2 fathoms, and in the southernmost $2 \frac{1}{2}$ fathoms, at high water; with southwesterly winds there is said to be a depth of 4 fathoms. The best time to enter is early in the morning before the sea breeze springs up.

There is a small Indian village nearly opposite the southern channel into the estero, called Palmito, where tolerably good fresh water may be obtained.

Anchorage.-The anchorage off boca Tecapan is about $\frac{3}{4}$ mile from the outer enge of the bar, in 6 or 7 fathoms of water, the middle and highest peak of the sierra Bayona, 2,588 feet high, bearing $\mathrm{N} .72^{\circ} \mathrm{E}$. (N. $63^{\circ}$ E. mag.), distant 14 miles.

Bayona river, which empties into an estero or lagoon, between 8 and 9 miles northward of boca Tecapan, forms the boundary line between the provinces of Sinaloa and Jalisco.

Coast.-The coast south of boca Tecapan assumes a somewhat more southerly trend, sweeping slightly to the eastward between the boca and a low, slightly projecting point 28 miles S. by E. of it. For over 27 miles from the boca Tecapan, a lagoon lies nearly parallel to the coast, the strip of sand beach between it and the sea varying in width from $\frac{1}{4}$ mile near the boca to $2 \frac{1}{4}$ miles near its southern limit.

The country for many miles back of the coast is low and level, two or three hills from 900 to 1,600 feet high, lying 15 or 20 miles inland, being 
the only ones seen throughout the entire distance. A few Indian huts and some patches of green bushes and trees are scattered along the coast.

From the low, slightly projecting point just mentioned, the coast trends SSE. for a distance of 18 miles to Camichen estero.

Camichen estero is the outlet of an extensive lagoon, which stretches northward. Off the entrance is a bar, over which the sea breaks. On the western shore of the lagoon, just north of the entrance, is a small settlement. Vessels come here for cedar and dyewood.

The usual anchorage is off the mouth of the estero, in 5 or 6 fathoms of water, about a mile from the shore.

Isabel island lies $17 \frac{3}{4}$ miles from the nearest point of the mainland, its highest peak bearing N. $74^{\circ} \mathrm{W}$. (N. $83^{\circ} \mathrm{W}$. mag.) from the bar off Camichen estero, 22 miles distant from it. It is about $1 \frac{1}{2}$ miles long, nearly NNW. and SSE., $\frac{1}{2}$ mile wide, and 280 feet high. Neither wood nor water can be obtained from it, and it is visited only by sealers.

There are several detached rocks near the island, the most prominent of which are two pinnacle rocks, nearly white, one 90 and the other 40 feet high, which lie near its northeastern side.

Landing.-On the eastern and southeastern sides of the island are sand beaches, where a landing may be effected in good weather. The soundings between Isabel island and the coast are regular, decreasing from 20 fathoms near the island to 6 and 7 fathoms $3 \frac{1}{2}$ miles from the coast.

Coast.-South of Camichen estero the coast continues its southeasterly trend, and is low and sandy. Between the mouth of the estero and San Blas, which is 19 miles to the southeastward, are the mouths of several lagoons and rivers.

Asadero estero is $7 \frac{1}{2}$ miles from that of Camichen, and has a shoal of small extent off it. The anchorage is in 5 or 6 fathoms of water, about $\frac{1}{2}$ mile from the beach. Vessels come here for cedar, deywood, etc.

Rio Grande de Santiago, or de Lerma, which takes its rise near the city of Mexico, feeds on its course Chapala lake (over 50 miles long), and, draining the larger part of the province of Jalisco, flows into the Pacific about 4 miles to the southeastward of Asadero estero. Guadalajara, the capital of Jalisco, is situated on the south bank, about 140 miles from its mouth.

A dangerous shoal, over which the sea breaks heavily, extends nearly 2 miles off its mouth.

Piedra Blanca del Mar is a small white rock, 145 feet high, lying $5 \frac{1}{4}$ miles S. $78^{\circ}$ W. (S. $69^{\circ}$ W. mag.) from the mouth of the rio Grande de Santiago. There is a safe passage between the rock and the shoal off the mouth of the river. From 8 to 9 fathoms will be found near the rock.

This rock is a good guide for making the port of San Blas, which is about 12 miles distant in an easterly direction. 
Piedra Blanca de Tierra is a small white rock 58 feet high, with two smaller ones, one NE. and the other SW. of it. It lies 1,200 yards S. $41^{\circ}$ W. (S. $32^{\circ}$ W. mag.) from the nearest land (Castillo de la Entrada), the channel between having a depth of from 3 to 4 fathoms.

The harbor of San Blas is nothing more than a small estero, having throughout the greater part of its extent very shoal water. The bar at its entrance has 7 feet of water on it at low tide. Inside, this depth increases to about 3 fathoms at low water. Vessels must moor, head and stern, in the estero, which is very narrow, and is perfectly sheltered from every wind.

The western shore of the estero is a narrow neck of land, or peninsula, in the southern part of which are some hills over 100 feet high, with the ruins of fortifications on them.

Directions.-The following directions for entering the harbor of San Blas are from Findlay's North Pacific Directory:

"By giving this point, which forms the harbor, a berth of 30 or 40 yards you will avoid a large stone, which is awash at low water, and is about 15 yards from the dry part of the rocks or breakwater. As soon as you are so far in that the innermost or eastern part of the breakwater is in line with the other part of it inside, which runs to the NNE., it may be approached to within 10 or 15 fathoms, and by keeping well off from the low, sandy point, as you warp up the harbor, you will have the deepest water. As the sea sometimes in the rainy season, although seldom, breaks over the natural breakwater which forms the harbor, it is best to moor close under the high part of the land, on which stands the ruins of an old fort, with the ship's head up the river, a bower laid off to the eastward and an anchor from the starboard quarter, the port side secured to the shore, either by taking out anchors or by making fast to the rocks. In this position it is next to impossible for any accident to happen to the ship; the cargo can always be discharged with dispatch immediately under the eye of the master or mate, and the landing place is only 200 yards from the ship. The longboat will do more in this anchorage than the two launches, which can never be used in the outer harbor in rough weather.

As there are no established pilots it is advisable to engage a person to point out where the large stone lies. The captain of the port is the best person to apply to, who, if he will not come off himself, will most likely recommend a suitable person."

The outer anchorage of San Blas is open and exposed to both the prevailing winds. It is safe in the dry season, and less dangerous than that of Mazatlan in the rainy months. The extent and configuration of the roadstead render it easy of approach, and when leaving it the prevailing 
current often affords considerable assistance. It is recommended to avoid remaining during the season of the Cordonazos.

A good anchorage is in $5 \frac{1}{2}$ to 6 fathoms of water, Piedra Blanca de Tierra bearing N. $26^{\circ} \mathrm{W}$. (N. $35^{\circ} \mathrm{W}$. mag.) distant about $\frac{1}{2}$ mile.

Landmark.-Mount San Juan, 7,550 feet high, is an excellent landmark for making the port of San Blas. It may be seen from a great distance, and is seldom obscured by fog, as the low lands frequently are. When seen from the westward it appears to be saddle peaked, and on a bearing $S$. $73^{\circ}$ E. (S. $82^{\circ}$ E. mag.) is nearly in line with Piedra Blanca del Mar and Piedra Blanca de Tierra. The coast range, from 1,000 to 3,000 feet high, lies between mount San Juan and the coast.

The land southward of San Blas is high, while to the northward it is low.

Directions.-When coming from the westward, bound to San Blas, pass close to the southward of Piedra Blanca del Mar and shape a course for Piedra Blanca de Tierra, keeping it a little open on the port bow and giving it a berth of 300 or 400 yards in passing; anchor about $\frac{1}{2}$ mile to the southeastward of it, in 5 or 6 fathoms. If it is desired to anchor nearer the town, pass between Piedra Blanca de Tierra and the Castillo de la Entrada and anchor in $4 \frac{1}{2}$ fathoms; a scant $\frac{1}{2}$ mile eastward of the rock.

Coming from the southward, steer for the westernmost hill, Castillo de la Entrada, 106 feet high, until approaching Piedra Blanca de Tierra, when anchor as before directed.

Caution.-Care must be taken in standing in for San Blas not to fall to leeward, as there is a strong southerly current setting along the coast during the greater part of the year.

San Blas at present has about 3,500 inhabitants and is the port of entry for Tepic and Guadalajera and the center of the trade in precious woods, as rosewood, mahogany, cedar, lignum-vitæ, Brazil wood, etc.

The old town of San Blas is at present a mass of ruins, with trees and bushes growing among them.

The United States is represented by a consul and vice-consul.

Supplies.-Fresh beef, vegetables, and wood can be obtained here. Water of excellent quality is found near the shore of ensenada Matenchen, 3 miles to eastward of San Blas.

Fevers, etc.-During the rainy season malignant fevers prevail, the effects of a marsh miasma generated in the numerous surrounding swamps; there are also myriads of mosquitoes and gnats, whose stings often cause painful and serious inflammatory disorders. At this season every one who is able leaves the town for the interior.

Remarks.-The following remarks are from Imray's North Pacific Pilot, Part I:

"On November 1 the dry season commences; the temperature rises steadily, and the land yields all its moisture, until, by the month of May, 
the heat of the atmosphere resembles that of an oven, and the air swarms with mosquitoes and sand flies; the sky is cloudless, the land and sea breezes regular but not refreshing.

Early in June heavy banks of dark lowering clouds, charged with electricity, collect on the high lands in the interior; lowering masses of clouds hang to seaward. The change is fast approaching, and before the 16 th of June the rains commence and deluge the land, accompanied by heavy squalls and a tumbling swell from seaward.

For the first month or six weeks the parched land absorbs the rain, but by the middle of August it becomest moist and swampy, the haunt of alligators and aquatic birds. In September the action of the sun on watersoddened land generates fever of the most violent nature, and it behooves those who arrive early in the dry season to be careful of exposure to the malária."

Steamers.-The Pacific Mail steamers touch here once a month, and the Atchison, Topeka and Santa Fe Railroad Company's steamers make regular semimonthly trips from Guaymas to Manzanillo, touching at La Paz, Mazatlan, and San Blas.

Tepic is an important town, situated on the eastern slope of mount San Juan, distant by the road about 28 miles from San Blas. It has a population of about 12,000, and is widely known for its manufacture of cigars. It has also a cotton factory.

Guadalajera, the capital of the province of Jalisco, is about 120 miles from Tepic, with which it is connected by a road. It has a cathedral, government building, theater, and several convents, and is quite prominent as a manufacturing city, the principal manufactures being leather goods, hardware, and cigars. It has a population of 83,000.

Las Tres Marias.-Off this part of the coast and from 50 to 60 miles distant from it is a group of islands extending 39 miles in a general NW. and SE. direction and known as Las Tres Manias. They are of volcanic origin and their western sides are high, inaccessible, barren cliffs, while the eastern sides are generally low and sandy, with some vegetation.

Maria Cleopha, the southernmost, is nearly circular in form, having a diameter of about 3 miles. The highest peak has an altitude of 1,320 feet. A pinnacle rock 100 feet high lies off the SE. point, distant about 1,600 yards, and a white rock 225 feet high lies $\frac{1}{2}$ mile off the westernmost point. A shoal on which there is a rock awash extends $\frac{1}{3}$ mile off from the $\mathrm{NE}$. extreme, and numerous smaller detached rocks lie a short distance off from the bold bluff points. The southeastern point is a yellowish bluff, surmounted by a steep hill 250 feet high. A heavy surf beats against all sides of the island. 
Maria Magdalena lies to the northwestward of Maria Cleopha, the channel between them being 8 miles in width and free from all dangers. It is 8 miles long, east and west, with a greatest wilth of $4 \frac{1}{2}$ miles, and its highest peak is 1,500 feet above the sea level. Just south of the eastern extreme of the island, which is a yellowish bluff about 200 feet high, is a small bight with 11 fathoms and upwards of water, rocky bottom. The NE. point is low and gravelly; a short distance west of it is a small lagoon. On the northern face, about midway of its length, shoal water extends off shore about $\frac{1}{2}$ mile, and off all the salient bluff points are outlying rocks, at distances varying from $\frac{1}{4}$ to $\frac{1}{2}$ mile from the shore. 'The shore of the northern side of the island is a fine sandy beach, the land sloping gradually from the interior.

There is considerable vegetation on this island, although the soil is of a sandy nature. The most valuable of its products is lignum-vitæ, besides which there is an almost impenetrable thicket of small trees and bushes of a thorny nature, together with the prickly pear and some plants of the orange and lemon species. Fish are abundant near its shores.

IIaria Madre is the largest of the group, being $11 \frac{1}{2}$ miles long nearly NW. and SE., and from 3 to 6 miles wide. The highest peak, near the middle of the island, is 2,020 feet high.

On the SE. face there is a small settlement of 15 or 20 people, who are occupied in collecting salt from a lagoon near by. The salt is shipped to Mexico.

The southern extreme of the island is a bold, rocky headland 12.5 feet high, with several detached rocks lying off it. Eastward of this headland there is tolerable anchorage, in from 7 to 11 fathoms of water, and a sand beach where boats may land in good weather.

Fresh water of an inferior quality may be procured on this part of the island by sinking wells.

From the NW. extreme a dangerous reef extends nearly a mile toward San Juanito island. Two miles south of the NW. point, and $\frac{1}{4}$ mile from the western shore of the island, is a detached rock, 5 feet above water, with a sunken rock between it and the shore.

The channel between Maria Magdalena and Maria Madre is 4 miles wide and free from dangers.

San Juanito, the northernmost and smallest of the group, lies 2 miles northwestward of Maria Madre. It is $2 \frac{1}{2}$ miles long, with a greatest width of $1 \frac{1}{4}$ miles, and about 200 feet high at its northern end, whence it slopes gradually to the southward.

From its southern end a reef extends a mile toward Maria Madre, which, with the reef extending off the NW. point of the latter, renders the channel between them extremely dangerous. 
Rock.-A remarkable white rock, 150 feet high, lies a mile off the western shore of San Juanito.

Caution.-The soundings increase rapidly from the shores of these islands, no bottım boing found at 100 fathoms, 2 miles distant. Calms, eddy winds, and southerly currents must be guarded against when navigating the channels between them.

The coast from San Blas to punta Raza is mountainous, and stands in marked contrast with the monotonous sandy plains farther north.

Camaron point, lying $2 \frac{4}{10}$ miles to the southeastward of San Blas, is a sharp, bluff point, with a ridge of hills terminating just back of it. Off it are some outlying islets and rocks. The mouth of the estero de San Cristobal is a mile north of the point. This estero is of no importance to navigation.

Ensenada Matenchen.-At Camaron point the coast turns sharply to the northeastward for about $1 \frac{3}{4}$ miles, and then curves around to the southward, forming an open bay called ensenada Matenchen, on the northern shore of which fresh water may be obtained. Shoal water extends $\frac{1}{2}$ mile off the shore of the bay, and there are some detached rocks lying to the eastward of Camaron point.

Santa Cruz point, with the river and village of the saine name, are at the southern limit of the ensenada Materichen.

Punta los Custodias is $5 \frac{1}{2}$ miles to the southward of Santa Cruz point, several steep, bluff points, from 45 to 75 feet high, intervening. It is a rocky, bluff point about 30 feet high, the coast range of hills rising abruptly behind it. The Custodias river, which empties into the sea just south of the point, has a bar at its mouth, over which the sea breaks.

From punta los Custodias a low straight sand beach extends southward for a distance of 8 miles, the land back of it covered by trees and bushes. Near the southern limit of this sand beach is a small stream known as the Chila river.

Chacala ensenada is a small cove situated $1 \frac{3}{4}$ miles south of the southern limit of the sand beach just mentioned, a bluff point 40 feet high intervening. From the shore of the cove, hills rise immediately, to a height of over 300 feet.

Tecusitan point.-A mile and a half south of Chacala ensenada, with some outlying rocks between, is a rocky, bluff point 70 feet high, called Tecusitan point.

About 10 miles S. $77^{\circ}$ E. (S. $86^{\circ}$ E. mag.) from Tecusitan point is a prominent peak of the main range of mountains, lying parallel to the coast, known as cerro Compostella. It is 4,262 feet high, and affords a good landmark.

Jaltemba bay.-Between Tecusitan point and punta Raza, 6 miles distant, the coast recedes somerwhat, forming the open bay of Jaltemba, in which vessels may anchor and find shelter from southeasterly winds. 
The shore of the bay is sandy, and the land back of it, which rises gradually, is covered with a thick growth of trees and bushes. Dyewood is shipped from here.

A line of soundings run from point to point across the bay showed no bottom at 13 fathoms.

Islet and rock.-A small whitish-colored islet 80 feet high lies about 2 miles to the northeastward of punta Raza and about $\frac{3}{4}$ mile from the shore. South of the islet, distant about $\frac{1}{2}$ mile, is a black rock 20 feet high. Vessels that come here to load dyewood anchor between the islet and the shore.

Punta Raza is a reildish-colored bluff point about 30 feet high, with hills rising abruptly back of it. It is distant 6 miles from Tecusitan point. Deep water extends close up to punta Raza; 20 fathoms were found at a distance of a mile, and no bottom at 13 fathoms within $\frac{1}{4}$ mile.

A little over a mile to the eastward of punta Raza, on the shore of Jaltemba bay, there is a small fresh-water stream.

Coast..-From punta Raza the coast has a general trend SE. $\frac{1}{2}$ S. for $21 \frac{1}{4}$ miles, to punta Mita, the northern point of the entrance to Banderas bay, and is a succession of bluffs alternating with sand beaches. The coast range, varying in height from 300 to 1,000 feet, borders on the sea throughout the entire distance. A short distance back of the coast is a higher range of mountains, the most conspicuous of which is cerro Vallejo, 5,036 feet high, eastward $10 \frac{3}{4}$ miles distant from Monterey point, and $7 \frac{3}{4}$ miles distant from the nearest part of the coast.

Monterey point is $8 \frac{3}{4}$ miles southwestward of punta Raza, and is a ragged bluff, with some outlying rocks on its NE. side. Three miles to the northeastward of it is an Indian village, close to the shore.

Santa Cruzita point is $4 \frac{1}{2}$ miles southwestward of Monterey point, and, like the latter, is a ragged bluff point.

Punta Mita, a low, narrow, projecting point, is surrounded by outlying rocks and reefs, which make a near approach to it dangerous. A mile and a half to the northeastward of the point is a prominent hill 454 feet high, and on the coast northward of the hill is a steep, rocky bluff 60 feet high. From the bluff the coast sweeps to the eastward $1 \frac{1}{2}$ miles, forming a small bight open to the northward, with lowland, covered with trees and bushes, between it and Banderas bay, to the southward.

For nearly $\frac{1}{2}$ mile to the westward of punta Mita there are outlying rocks and shoals, outside of which the depth of water increases quickly to 15 and 20 fathoms.

Rock.-One mile S. $22^{\circ}$ W. (S. $13^{\circ} \mathrm{W}$. mag.) from punta Mita is a dangerous shoal and rock awash, over which the sea breaks in rough weather. In the passage between the rock and the point there are from $2 \frac{3}{4}$ to 4 fathoms of water. 
Las Tres Marietas are a group of small islands, rocks, and shoals, extending $5 \frac{1}{t}$ miles in a general ENE. and WSW. direction, the easternmost and largest of which is on a line between punta Mita and cape Corrientes, bearing S. $21^{\circ} \mathrm{W}$. (S. $12^{\circ} \mathrm{W}$. mag.), distant $4 \frac{1}{4}$ miles from the former.

The easternmost island is less than $\frac{1}{2}$ mile in extent and $17: 1$ feet high, rising in broken white cliff's to the higher parts, which appear flat. A mile to the westward of it is the second of the group, somewhat smaller than the first, but similar to it in character, and 132 feet high. Surrounding this island, and in the channel between it and the first, are numerous detached rocks. A mile and a half farther westward, its center bearing S. $41^{\circ} \mathrm{W}$. (S. $32^{\circ} \mathrm{W}$. mag.), distant $6 \frac{3}{4}$ miles from punta Mita, is a reef of rocks above and below water, with deep water close to. The third island of the group is a mile and a half westward of the reef and $\frac{8}{10}$ miles S. $48^{\circ}$ W. (S. $39^{\circ}$ W. mag.) from punta Mita. It is merely a white rock, 40 feet high; $\frac{1}{2}$ mile to the westward of it is a smaller rock, 15 feet high. There are 40 fathoms of water close to these rocks.

Channel.-Between the Tres Marietas and punta Mita is a clear, safe channel; but in using it care must be taken to avoid the rock awash, that lies a mile to the southward of punta Mita. This is easily done by keeping a little nearer the islands than the point.

Anchorage.-There is an excellent anchorage during the season of the $\mathrm{NW}$. winds $1 \frac{1}{2}$ miles eastward of punta Mita, in from 5 to 7 fathoms of water, from $\frac{1}{2}$ to $\frac{3}{4}$ mile off shore, the hill, 4.54 feet high, to the northeastward of the point, bearing N. $20^{\circ} \mathrm{W}$. (N. $29^{\circ} \mathrm{W}$. mag.).

Supplies.-Fresh water in small quantities may be found near the beach. Game is abundant in the interior. A species of wild turkey, called by the natives chachalaca, is found in large flocks, furnishing excellent meat.

Corvetena rock, which is of a whitish color, 600 yards in length and 25 feet high, lies $16 \frac{1}{2}$ miles S. $83^{\circ} \mathrm{W}$. (S. $74^{\circ} \mathrm{W}$. mag.) of punta Mita. It is irregularly shaped, with a very jagged top, and in a clear day can be seen from the deck of an ordinary vessel at a distance of 8 or 10 miles. There are 40 fathoms of water close to the rock, and from 50 to 100 fathoms between it and punta Mita.

Current.-A strong current was noticed in its vicinity, setting to the $\mathrm{SE}$. Banderas bay, sometimes called Valle de Banderas bay, is formed by a deep indentation in the coast between punta Mita and cape Corrientes. It is 20 miles in extent east and west, with an average width of about 15 miles. The northern shore of the bay, as far as punta Piedra Blanca, $7 \frac{3}{4}$ miles from punta Mita, is, with the exception of a short strip of sand beach just east of the latter point, composed of broken bluffs from 10) to 20 feet high. From punta Piedra Blanca to the rio Real, which empties into the head of the bay, the shore is a sandy beach. The southern shore from 
the rio Real to cape Corrientes is high and precipitous, with occasional valleys and sand beaches, where small fresh-water streams empty into the bay. The water along the southern shore is very deep.

Pedredero point, 5 miles to the eastward of punta Mita, is a rocky point, with a large outlying rock iff it. Two and a half miles northeastward from it are some conspicuous hills over 1,800 fect high.

Punta de Piedra Blanca, which is surmounted by a hill 300 feet high, lies about 3 miles eastiward of Pedredero point. Along this part of the coast are some outlying rocks, close to.

Eastward of punta de Piedra Blanca is a small ensenada, where excellent anchorage may be found in the season of $\mathrm{NW}$. winds.

The estero de Tomates, into which the rio del Valle or Piginto empties, is $7 \frac{3}{4}$ miles southeastward of punta de Piedra Blanca, the intermediate coast, which recedes considerably to the northward, being low, sandy, and covered with bushes, the soundings off it increasing regularly, from 3 and 5 fathoms near the shore to 15 and 20 fathoms a mile or so off.

Shoal.-Off the mouth of the estero is a shoal, over which the sea breaks. Outside of this shoal the soundings increase very rapidly, 99 fathoms, rocky bottom being found $\frac{3}{4}$ mile from the mouth of the estero.

Peñas.-The village of Peñas is situated about 4 miles to the southeastward of the mouth of the estero de Tomates, on the bank of the rio Real, which empties into the head of the bay. The hills back of Peñas rise abruptly to a height of over 1,000 feet, and high mountains are plainly visible 10 or 20 miles to the eastward. One and a half miles northward from Peñas is a grove of palms and a lagoon called estero de Paran.

Anchorage.-There is an anchorage in good weather cff the mouth of the rio Real, close to the beach. The soundings off shore deepen very quickly, no bottom being found at 25 fathoms, 400 yards from the beach. Vessels come here for dyewood.

Fresh water of excellent quality may be obtained from the river.

Los Arcos are three rocks lying near the southern shore of the bay, between 4 and 5 miles to the southwestward of the mouth of the rio Real. The highest of these rocks is 291 feet high ; the other two are 20 and 30 feet high, respectively. From Los Arcos to cape Corrientes the coast is bold and backed by mountains from 2,000 to 3,000 feet high. Soundings obtained off it gave no bottom at 100 fathoms, a mile from the beach. There are some outlying rocks of the rocky, bluff points, and at the mouths of the several fresh-water streams that flow into the bay are collections of Indian huts.

Chimo point is a rocky headland, situated 7 miles to the northeastward of cape Corr entes. Just east of the point is a reef of rocks, and a short distance westward of it is a white rock 40 feet high. The river Chimo empties into the bay on the eastern side of the point. 
Tabo point and bay.-Tabo point is $4 \frac{1}{2}$ miles southwestward of Chimo point, and forms the northeastern limit of Tabo bay, which is a small open bay at the hearl of which are a few Inclian huts on the banks of a small stream which flows into the bay and is called by the same name. It is impossible to anchor in Tabo bay on account of the great dejth of water, 60 fathoms being found within a ship's length of the shore.

Corrales harbor.-West of Tabo bay, separated from it by a high hill, is the so-called harbor of Corrales, the western limit of which is only $\frac{1}{2}$ mile from cape Corrientes. It is about $\frac{1}{2}$ mile in extent, but affords no anchorage.

A sunken rock, on which the sea breaks in rough weather, lies off the mouth of the harbor about 600 yards from the shore.

Cape Corrientes, the southern point of the entrance to Banderas bay, is a bold headland 506 feet high, the land a short distance back of it rising to a height of 2,000 feet. There is a large outlying rock close to the cape. Soundings obtained 600 yards from it gave 145 fathoms.

Current.-Capt. W. H. Parker, of the Pacific Mail Steamship Company, says: "The current runs from cape Graham along the coast toward cape Corrientes, generally about NV., but sometimes setting north with considerable velocity into Natividad, Tenacatita, and Perula bays. You may be cut in a good deal and must look out for it."

Revilla Gigedo islands consist of four islands lying between $18^{\circ} 20^{\prime}$ and $19^{\circ} 20^{\prime} \mathrm{N}$. lat. and $110^{\circ} 45^{\prime}$ and $114^{\circ} 50^{\prime} \mathrm{W}$. long.; are of volcanic origin.

Socorro island, 3,707 feet high, the largest, may be said to consist of one mountain covered with a thick growth of cactus, which renders it almost impossible to penetrate the interior. A species of bean grows on a vine which runs along the ground. Capt. Colnett's men are said to have become very sick from eating it. No indications of fresh water were seen, but it is said there are goats on the island, which would hardly be the case if no fresh water could be found. Fish, turtle, crabs, and crawfish were abundant.

The Cove.-The Cove, south end of Socorro island, is the first indentation of the coast eastward of cape Rule, and Braithwaite bay is the second indentation of the coast eastward of cape Rule, being about a mile from the cape.

The Cove has a stony beach, in the center of which is a small sand beach, where the only good landing will be found.

Braithwaite bay.- There is a good anchorage in this bay during the fine weather season, that is, from December to .June, with any but southerly and easterly winds. The beach at the bottom of the bay is a mixture of stones and rocky ledges, on which the boats of the U. S. F. C. steamer Albutross landed without much trouble, the weather being fair. 
The bay is readily distinguished by the stony beach, the only one on the south side of the island.

Wishing to anchor, bring the lighest peak of the island to bear $\mathrm{N}$. $24^{\circ} \mathrm{W}$. (N. $33^{\circ} \mathrm{W}$. mag.), and anchor in 10 or 11 fathoms 1 mile from the beach. There is a good landing on the beach at the head of the cove.

Cape Rule, the southern extremity of Sorocco, is a high, rocky bluff, surmounted by a hill 250 feet high.

Cornwallis bay, on the SW. side of the island, affurds good anchorage in easterly winds. It is necessary to anchor quite near the white coral beach, as the water deep'ns quickly off shore. In the western part of the bay are some pinnacle rocks 30 feet high.

Rugged point is the western extreme of the island; north of it is a small bay, near the head of ' which is a double-pinnacle rock 25 feet high.

Cape Henslow, at the northern limit of the bay just mentioned, is a perpendicinlar bluff 100 fe'et high.

Oneal rock, lying a mile N. $25^{\circ} \mathrm{W}$. (N. $34^{\circ} \mathrm{W}$. mag.) from cape Henslow, is about $\frac{1}{2}$ mile in extent and $t 5$ feet high, with deep water close to.

Off the NW. face of the island, between cape Henslow and cape Middleton, there are several outlying rocks.

Cape Middleton is the northernmost point of the island, and is a perpendicular bluff 50 feet high. A little over a mile to the northeastward of it are two small rocks, one 15 and the other 50 feet high.

The eastern side of the island consists of perpendicular bluffs, varying in height from 15 to 150 feet, with no place where a landing might be effected, even in the finest weather.

Cape Pearce, the easternmost point, has some outlying rocks close to; back of it is a range of table mountains about 1,000 feet high.

At $4 \frac{1}{2}$ miles to the northweitward of cape Pearce is a detached rock, 6 feet above water, close to the shore.

Remarks.-The following remarks are from Findlay's North Pacific Directory : "Captain Colnett consilered the safestanchorage from June to December to be between the south and SW. points (Cornwallis bay), opposite tn two white coral beaches, which are the first two in succession from the south point towards the west. It is remarkable from the pinnacle rocks which lie close off the west point of the bay. This bay is preferable in the bad season, as the wind seldom blows more than two points to the southward of east. In the good season, however, that is, from the latter part of December until the beginning of June, the SE. (or Braithwaite bay) is to be preferred; the anchorage here is better and nearer the cove, and is the only good landing place. It is readily known, being a stony beach at the first inlet in the shore to the eastwarl of the south point. All other points 
of the coast on the south side of the islan'? are iron bound, which makes it difficult if not impossible to land."

San Benedicto island .lies 30 miles N. $17^{\circ}$ E. (N. $8^{\circ}$ E. mag.) from the highest point of Socorro. It is a bairren rock 3 miles long and from $\frac{1}{2}$ to $\frac{3}{4}$ mile wide. The highest peak is near the southern end, and has an altitude of 975 feet. There is another peak somewhat lower, near the middle of the island. These two peaks, when seen from a distance, have the appearance of two distinct islets.

Landing.-On the eastern side of the island, near the middle, is a small shingle beach. There is fairly good anchorage off the shingle beach. The best landing is on this beach, but other portions of the island can not be reached from it though people may be landcd on the rocks at the foot of the bluff further to the northward.

Rocks. - There are three small detached rocks, varying in height from 60 to 200 feet, lying close to the western shore of the island, near the northern point, and a dangerous sunken rock lies about a mile westward of the extreme western point.

Roca Partida is a small, dangerous, barren rock, 110 feet high, lying 67 miles N. $80^{\circ} \mathrm{W}$. (N. $89^{\circ} \mathrm{W}$. mag.) from the highest part of Socorro. It consists of two white pinnacle rocks connected by a low ridge 20 feet high. The low part not being visible very far, it has the appearance of two separate rocks.

It is 300 feet long and 150 feet wide, and from a distance locks like a vessel under jury masts.

Soundings of 35 fathoms, were found all around it, at a boat's length from the rock. At $\frac{1}{2}$ mile distant 50 fathoms were found and beyond that no bottom at 100 fathoms.

Clarion island is of volcanic origin, and of the same general character as Socorro, from whiç it bears S. $83^{\circ} \mathrm{W}$. (S. $74^{\circ} \mathrm{W}$. mag.), distant 214 miles. It is a little over 5 miles long, nearly east and west, and from one to 2 miles wide, being widest at its western end. There are three prominent peaks, 1,282, 916, and 996 feet high, respectively, the highest being near the western end. A thick growth of cactus covers the island.

Sulphur bay.-On the south side of the island are two indentations in the coast, with sand beaches, the only two places of the kind on the island. The western of these two indentations is called Sulphur bay. Its western limit is $1 \frac{1}{2}$ miles from Rocky point (the $\mathrm{SW}$. point of the island), and in it may be found tolerable anchorage, in northerly winds, in 12 or 13 fathoms of water, 600 yards from the sand beach. Near the beach is a salt-water lagoon, but no fresh water was found. As doves are quite numerous, there must be fresh water on the island.

With the exception of the two sand beaches mentioned, the shores of the island consist of perpendicular bluffs, varying in height from 80 to 600 feet. 
Shag rock, 40 feet high, with numerons smaller rocks close to it, lies off the SE. point of the island, close to a bold bluff.

Otf the north sic'e of the island, $1 \frac{1}{4}$ miles from the $\mathrm{NW}$. point, and about 375 yards from the shore, is a detached rock 25 feet highl.

Monument rock.-Off the NW. point of the island is a remarkable monument rock, 200 feet high, with a number of smaller rocks between it and the point. It has an almost square base and is surmounted by a broken pyramidal shaft of alternate layers of red and white conglomerate rock.

Supplies.-Fish and turtle were numerous in the vicinity of the island, also many varieties of sea birds.

Soundings obtained south of Clarion island gave 20 fathoms and over $\frac{1}{2}$ mile from shore, increasing to 40 and 50 fathoms at a mile distant. The current in the vicinity of the group is southerly and from half a knot to a knot.

Reported islands and shoals.-Careful search has been made for the many islands and shoals that have been reported in this vicinity at different times, without finding them or any indication of them. 


\section{CHA PTER I V.}

THE COAST OF MEXICO, FROM CAPE CORRIENTES TO THE OCOS RIVER.

Cape Corrientes derives its name from the currents off it, which set to the northward and westward into the gulf of California, and is a bold and lofty headland with a flat summit which rises to the height of 50 feet. On approaching it from any direction the high land back of it is first seen. The mountains are covered with woods, which in the rainy season are green and in the dry season dark brown. From the northward and westward the cape does not present a remarkable appearance, but from the southward and eastward it is bold and projecting. It may also be distinguished by a white rock patch on the side of the slope, well down, and by the reddish brown rocks at the base, whereas the points near it are grayish bluffs and rocks.

Ysatan point is about 3 miles to the eastward of.cape Corrientes and is a grayish rock point, a sand beach intervening between them. It appears to be the farthest projecting point on almost any line of approach, and may be easily mistaken for cape Corrientes.

The currents off this point are the most remarkable on this coast. Capt. W. H. Parker, late of the Pacific Mail Steamship Company's service, says: "And here I must caution you against one of the most marked currents on this coast; the current running from cape Graham along the coast toward cape Corrientes generally about NW., but sometimes setting north with considerable velocity into Navidad, Tenacatita, and Perula bays. You may be cut in a gond deal and nust be on the lookout for it." *

Dangers.-There are no dangers off the cape which can not be seen, and a vessel can pass in safety within $\frac{1}{4}$ mile of it. There is a shoal or ridge to the westward of the cape with 50 fathoms on it, which has deep water both outside and inside of it ; this may account for some of the tiderips and broken water seen at times off this point.

Landing. - A heavy sea breaks on the beach so that landing is impossible, but a good landing may be had in Corrales bay, about $\frac{1}{2}$ mile to the northward and eastward of the cape.

Coast.-From cape Corrientes the coast line trends about SSE. for 6 miles, with low yellowish rock bluffs on the intervening white sand beach.

Cucheritas rocks.-At this turning point (Cucheritas) in the shore is a group of low rocks on the beach called the Cucheritas, with a low reef

* In Uctober, 1892 , the U. ‥ S. San Francisco experienced in the vicinity of cape Corrientes a current setting along shore to the SE. at the rate of from $\frac{1}{2}$ to $\frac{8}{4}$ knot per hour. 
extending out in a SW. direction about $\frac{1}{4}$ mile from the beach. The highest rock of this reef is only about 3 feet above water, and the breaks on and around it can be seen 6 or 8 miles.

If Corrientes is passed close to, Cucheritas shuts out Y pala point.

Ypala point when siglited off the cape stands out as a moderately high and bold-faced rocky bluff point of a grayish color. It is about 7 miles from the above-mentioned reef, the coast between of an unbroken white sand beach. There are no outlying dangers off this point, the only rocks being on the west side of the point and inside of a tangent to its extremity.

Anchorage.-On the southeastern side, where the sand beach begins, is a cove where small vessels can anchor and find shelter from all but southerly and southeasterly winds. Anchor in about 5 fathoms of water, and be particular not to run too near some sunken rocks that lie about 30 yards from the beach near the left center of the cove. Larger vessels may anchor farther out on good holding ground in 10 fathoms, with the white house bearing S. $78^{\circ}$ E. (S. $87^{\circ}$ E. mag.) and about $\frac{1}{2}$ mile from the beach.

The landing is bad except in the cove, where natives have two or three canoes moored.

Supplies.-Vessels. load here with logwood, etc. Eggs, chickens, and such produce can be obtained from the natives in small quantities.

Village.-About $1 \frac{1}{2}$ miles to the eastward from the point and indicated by a low place in the shore range of hills, is the closed mouth of a lagoon and near it a small village lying back from the beach but hidden by the trees. About 500 yards to the left of the lagoon and 150 yards from the beach stands a white adobe house among the trees; this is the only structure visible from the anchorage.

Coast. - From Y pala point the coast trends southeastly to a rocky point about 20 miles from Corrientes, the shore being a sand beach with a woody back ground. This rocky point is low and not remarkable; about 200 yards off the point are a few sunken rocks. From this point the coast trends SE. by S. for 6 miles and then about SE. for nearly 17 miles to Black Rock point, a high sand beach extending nearly the whole distance. At nearly 2 miles from the rocky point is a large lagoon with a closed mouth (except in rainy season). This lagoon appears to extend to the southward and eastward into a large valley, back of which is a shore range of hills. This range contains near its eastern end, and distant about 3 miles from the beach, a pyramid-shaped mountain 916 feet high, being easily recognized. About 7 miles farther on is another closed lagoon, one mile eastward of the low sandy point which marks the change in direction of shore line. The surf is heavy along this beach, and landing can only - be attempted with danger. A third lagoon lies 18 miles southeastward of the rocky point. 
Black Rock point is about $4 \frac{1}{2}$ miles from this lagoon; it is so called from its appearance and the knob back of it. Although nearly white from the deposit of gulls and other sea birds, it generally shows black from seaward. The rock when first sighted appears well outside a low bluff point under a peculiar black knob which forms the western extremity of a shore range of hills that extend to the eastward, diverging from the coast. This knob is 655 feet high, and is easily recognized from either side, making a good landmark for the locality of Black rock.

Black rock, 35 feet high, is irregular in shape, and has a low rock just outside and close to it. There are also a few sunken rocks close to the inner side. Vessels may pass within $\frac{1}{4}$ mile of the rock without danger. At the end of the sand beach, to the westward of the point, there is a stream or lagoon where boats may find a landing. On the west side of the point, $3 \frac{1}{2}$ miles to the southward of Black point, are several kuts, and to the right of them is a large lagoon, mouth not open during the dry season, but which seen from seaward appears like a river mouth. In front of the huts and 200 yards from the beach is a low rock 3 feet out of the water, with sunken rocks near it, upon which the sea breaks. Off the southern side of the point is a cluster of rocks 2 or 3 feet high.

There are sunken rocks all around and immediately under the point, and all vessels should give the point a berth of at least one mile.

Coast.-From Black Rock point the beach continues in a SE. direction nearly 3 miles to a low, flat, rocky point that extends out 400 yards from the general beach line. When first seen it appears to be a small island, but on a closer approach a short and narrow sand strip is found to join it to a low bank on the shore line.

To the southward and eastward of this rocky point a sand beach extends about 4 miles until it meets the bluffs to the westward of Chamela bay. From the end of this sand beach, just behind which is a closed lagoon, extend bluffs and short sand beaches for 5 miles to the NW. point of Chamela bay. The first bluff is a short one, and is separated by a shingle beach $\frac{1}{2}$ mile long, from the next rocky bluff point, which from the westward resembles an island and has a group of low rocks outside of it. The shore line then bends in, forming a shallow bight with three short sand beaches at the bottom. These beaches are separated from each other by two dark red bluffs. There is a group of rocks lying $\frac{1}{2}$ mile off the first of these bluffs and bearing south from it. They are within the bight and out of the track of vessels.

From cape Corrientes to Chamela bay the water is shoaler than along any other section of the coast, and vessels may anchor off any of the sand beaches, but this coast is not considered safe between June and the end of November, during which time SE. and SIV. gales are prevalent, bringing in a heavy sea. 
Rivas point.-At the NW. entrance to Chamela bay is a bold cliff, of reddish-brown bluff's, not distinctly marked, with outlying rocks, on which the sea continually breaks. The hill over the point rises to a height of 200 feet.

Chamela bay is the first noticeable indentation of the coast to the southward and eastward of cape Corrientes, and is called Perula bay on some charts. It is a shallow bight, sheltered by a chain of islands and extending from Rivas point to Flat Top point, its SE. extremity, having a length of 5 miles and a depth of $1 \frac{3}{4}$ miles.

Islands.-Two conspicuous islands occupy a central position between the headlands. The most westerly of these is Passarera, 186 feet high, remarkable for its perpendicular white cliffs, which are seen from a long distance; the other large island, Colorado, having a reddish appearance, takes its name from its color. It is lower than Passarera and more regular in shape, being about 160 feet high. About 300 yards from the NE. end of Passarera and between it and Colorado is the small islet of Novilla, from which a shoal with $3 \frac{1}{2}$ and 4 fathoms on it extends in a NE. direction to the beach.

Cocina is a small island 110 feet high, $\frac{3}{4}$ mile ESE. from Colorado. To the southward and eastward of Cocina are several small islands and islets, the principal of which are San Pedro, San Augustin, Sphynx, San Andres, and Negrita, with sunken and outlying rocks around them. From Rivas point a chain of rocks extends to the eastward, close to the land, with deep water close outside of them.

Entrances.--Between the most easterly rock on the west side of the bay and Passarera there is a passage of a mile in width, with least depth of 13 fathoms 250 yards from the rock, and 11 fathoms less than $\frac{1}{4}$ mile from Passarera. There is also another passage $\frac{3}{4}$ mile wide, with deep water, between Colorado and Cocina.

Anchorage.-The best anchorage is in the NW. part of the bay, where 6 fathoms of water is found within 500 yards of the beach, with protection from all but southerly winds. In anchoring here be governed by the size of your vessel and her draft, as there is anchorage anywhere within a line from Perula point to the north end of Passarera. Small vessels anchoring closer in, in the bight, get more out of the swell, which is heaviest during the period of full and change. Another anchorage is between Colorado island and the beach to the eastward, but it is more exposed; yet, if wishing to communicate with the village of Chamela, this is the inore desirable. Small vessels anchor inside of Cocina island, in 4 or 5 fathoms, $\frac{1}{2}$ mile from the village. Inside of this it shoals rapidly. During the fine or dry season, from November to June, when the sea breeze from the northward and westward is regular during the day and the land breeze at night, the anchorage is perfectly safe in any part of the bay; but during 
the rainy season, June until November, gales from the SE. or SW. are frequent and occasion heavy seas.

The village of Chamela, located at the SE. end of the bay, is a port of entry, with the regular customhouse officials. A large white house, situated on a bluff, can be seen a long distance at sea, particularly with the sun past the meridian. A stream of fresh water flows into the bay just north of the village and at the base of the bluff on which the white house stands.

Supplies of fresh beef, chickens, eggs, fruit, \&c., can be had in small quantities by giving notice in the village.

The exports are chiefly hides and dyewoods, the latter of an inferior quality.

\section{Tonnage dues are $\$ 1$ per ton.}

Directions.-In approaching Chamela bay two prominent mountains lying back of it form excellent landmarks, easily seen and recognized in clear weather for a long distance on either side of Chamela. The nearer one, Gueguenton, lies about 11 miles N. $73^{\circ}$ E. (N. $65^{\circ}$ E. mag.) from . "the observation spot at the head of the bay, while the other lies N. $60^{\circ} \mathrm{E}$. (N. $52^{\circ}$ E. mag.) 5 miles from Gueguenton, and is 4,675 feet high. Its appearance from either up or down the coast is about the same. Wishing to enter Chamela, bring these mountains in range bearing N. $60^{\circ} \mathrm{E}$. (N. $52^{\circ}$ E. mag.) and stand in on this course until near Passarera or Colorado islands, then go either to the east or west of the islands, according to where you desire to anchor. Just to the southeastward of Chamela is a hill in the nearest shore range 1,265 feet high, with low and yellow bluffs just under it. These, with the hill, might be used in approaching from the eastward when the mountains are shut in by haze, smoke, or rainy weather. Passarera will be the mark, under the same conditions of the weather, when coming from the westward.

Farallon point and anchorage.-To the eastward of Chamela point the coast line for upwards of 6 miles is a succession of low rocky bluffs terminating at a sand beach; the end bluff (eastward) shows a whitish face from seaward. This sand beach curves around to the southward and from its end extends Farallon point, which is low and rocky. The point forms the southern part of a fairly protected anchorage in the season of southeasterly winds. The anchorage, in 10 fathoms, about $\frac{1}{4}$ mile from the beach, with Farallon point distant $\frac{1}{2}$ mile, is marked by a clear-cut bluff resembling a palisade, a few yards back from the shore near the southern end from the anchorage. The landing for boats is fair at the southeastern end of the sand beach.

Just off Farallon point lies a small rock islet that resembles a low bluff at a distance, with a small rock just at its western end. From this point 
the coast line trends southeasterly, for 6 miles, to a turn, off which lie two remarkable needle-shaped rocks called Los Frailes.

Los Frailes, 75 and 120 feet high, stand out clearly and distinctly from the land, and at times having the appearance of a sail. The outer Fraile is one mile from the beach, and the inner one about $\frac{7}{10}$ mile.

The inner one, with three or four low rocks about its base, shows sharper than the outer. The top is white from the deposits of sea birds. Between these two rocks there is a passage of $\frac{1}{4}$ mile wide, with plenty of water and free from hidden dangers. Inside the inner Fraile, and about 15') yards distant, lies a small, low rock, and still farther inside a rock cluster and reef extends nearly to the bluffs. A vessel might pass between the inner Fraile and this reef in case of necessity, but it is not safe. There is deep water close to the outer Fraile and no hidden dangers near it. A few low rocks lie off the SE. side close to the base, but not in a dangerous position. Vessels may pass the outer Fraile within 200 yards, if necessary.

From the Frailes to Brothers point, the NI. head of Tenacatita bay, distant 5 miles, the coast is a sand beach with two rock bluffs breaking it at short intervals. On the east side of the second bluff a lagoon empties into the sea.

Brothers point is a large bluff headland 185 feet high, with a remarkable double hill over it, which from the westward has the appearance of an island. Off Brothers point, and to Squall point, are many low, detached rocks, with sunken reefs and rocks awash in between. Vessels should not approach either of these points within $\frac{1}{2}$ mile.

Bird rock lies $\frac{3}{10}$ mile off Brothers point. It is a square, perpendicular rock 152 feet high, of a reddish brown color with a whitish top. It has a sharp and lower rock off its south face, appearing as a part of it.

Porpoise rock, $1 \frac{2}{5}$ miles westward of Bird rock, is about 12 feet high and on a range from the outer Fraile and the inner slope of Navidad head. It can easily be seen in coming from the westward and appears to lie well out from the bluffs to the westward of Tenacatita bay. It may be passed close to in rounding into the bay, but on no account should an attempt be made to go inside of it, as there are many sunken rocks between it and the shore.

A sunken rock with only a couple of feet of water on it lies N. $43^{\circ} \mathrm{E}$. (N. $35^{\circ}$ E. mag.) of Porpoise rock and distant $\frac{1}{3}$ mile.

Tenacatita bay is a large indentation lying between Brothers point and Navidad head. This bay contains West bay, a small cove in the northwestern part, and Tamarinda bay in the eastern part. It is free from dangers with the exception of Center rock, the depth of water being regular, vessels of any size may enter with perfect safety and find a good 
anchorage. Detached rocks lie off all the eastern shore of the bay, with deep water close to them.

Center rock, about 10 feet high, lies in the NW. part of the bay, $\frac{2}{5}$ mile off Squall point. It has plenty of water all around and close to it.

Anchorage.-The best anchorage and one well sheltered during the rainy season is in the northeastern part of the bay, off Tenacatita village, in 10 fathoms of water, about $\frac{1}{4}$ mile from the long sand beach, towards. which the water shoals gradually. This excellent anchorage is well sheltered during the rainy season. In West bay vessels of light draft will find a good anchorage in 7 or 8 fathoms sheltered from nearly all winds, but must pass to the eastward and northward of Center rock. Vessels can anchor in Tamarinda bay, where the boat landing is better than off the village, but it is not convenient for loading or discharging cargo.

Supplies.--Provisions can not be obtained here without sending into the interior, and then only beef, chickens, and eggs. Water is procurable near the village and firewond and coquita nuts and shells are abundant. These shells can be used for fuel in case of necessity; 3 tons of them are about equal to one of coal for steaming purposes. In buying these shells it is best to deal directly with the natives.

Navidad head, 400 feet high, is remarkable when seen from any direction. It is a wedge-shaped, high, rocky island ridge making straight out from the mainland. In one place the division is complete, forming two islands, separated by a very narrow passage. The inner island is separated from the mainland by a narrow and rocky passage through which boats may, with great caution, pass in a still time. The outer extremity of Navidad head is the highest point and forms the head proper; when bearing north it has the form of a wedge.

Extending out from the head in a SSW.direction are three large rocks, which are additional marks for Tenacatita as well as for Navidad bay, some 7 miles to the eastward of them. The inner and highest of these rocks is a dark rock just under the head and is about 115 feet high; as seen from the westward, there are two lower and sharp rocks on its right.

White rock. - The second rock lies about $\frac{3}{8}$ mile outside the head, it is about 100 feet high, rather square in shape, with a pointed or rounded top. The top shows dark, while the niddle portion, tapering to the base, shows white, from the deposits of sea birds.

This rock is often mistaken for the white islet off Manzanillo.

The third principal rock is lower, only 40 feet above water, and of a dark color. It lies $\frac{1}{2}$ mile outside the head and has several small, low rock clusters just outside of it.

Inside the limits of Tenacatita bay, and nearly opposite the end of the island ridge forming the head, lies a group of white rocks, which show out $11562-10$ 
very prominently against the dark background when approaching from the westward.

Sunken rock. - Outside of the above-mentioned cluster and S. $21^{\circ} \mathrm{W}$.

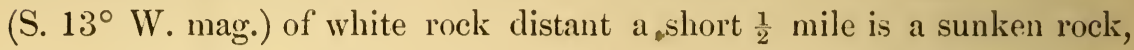
over which the sea breaks at most times. A rock awash lies $\frac{1}{5}$ mile eastward of white rock but is out of the way of all vessels.

Coast.-From Navidad head to the N W. bluff's of Navidad bay, distant about 6 miles, the coast trends to the eastward and presents a broken line of rocky bluffs from 50 to 100 feet high ; back of the bluff's the country is woody and hilly, rising to a height of 4,000 feet. Four miles eastward of the head is a deep bight, in the west side of which are several sharp-pointed rocks, the highest being about 40) feet high. This bight has two short sand beaches at its head with a small stream coming in on the southern side.

Harbor point.---At the northern entrance of the bay is a high projecting point which, with several detached rocks, forms the shelter or protection for the anchorage with the wind from the SW.

Navidad bay lies between Harbor point on the north and Graham head on the south. It is about $1 \frac{1}{2}$ miles wide and $\frac{4}{5}$ mile deep, with a sand beach at its head.

There are two small villages at either end of the beach, which are inhabited only during the dry season, the people wisely moving into the interior while the rains last. A small lagoon near the village at the western end of the bay extends to within a short distance of the beach and breaks through it during the rains; the water is not recommended for use.

Near the eastern end another lagoon empties into the bay. There is $1 \frac{1}{2}$ fathoms at its mouth, through which a strong current runs, and, though the lagoon is very shallow, it is navigable for boats at all seasons, the natives say for 20 miles into the interior.

Anchorage.-During the dry season this is an excellent anchorage, but it is not recommended for sailing vessels at other times, as they might have difficulty in getting out with the prevalent southerly winds. Sailing vessels might anchor further out, but there will be more swell.

Supplies.-Beef, chickens, eggs, and fruit can be had in small quantities from the natives by giving a few days' notice. The best oranges on the coast of Mexico are found here at the cheapest rates, and coquita nuts are abundant. In obtaining supplies here, as in all other places in Mexico, deal with the natives.

Graham head, 700 feet high, in common with all others on this coast, appears as an island when first sighted at a distance. A reddish conical rock (Cone rock) 280 feet high lies close under the head on the west side, but it is not readily seen against the background at any distance.

A rock 8 feet high lies $\frac{3}{5}$ mile from the nearest point of the beach under Graham head. Vessels passing this point should give it a berth of at 
least $\frac{3}{4}$ mile. There are no known dangers outside the low rock mentioned above.

Coast.-From Graham head the coast trends about E. by S. for nearly $13 \frac{1}{2}$ miles to the bluffs at the western entrance to Manzanilla bay. A sand beach extends the whole distance and the country just back of it is low and partly occupied by a large lagoon, remarkable for its bilge-water stench. The wreck of the S. S. Golden Gate lies 9 miles from Graham head; only a portion of the wreck remains.

Piedra Blanca, or White island, the principal landmark for Manzanilla bay, lies one mile southwestward of the junction of the sand beach and bluffs. It is nearly circular in shape and about $\frac{1}{4}$ mile in diameter, but is irregular in outline and height. The highest point, 260 feet high, is on the south side, with all its faces precipitous. From the deposits of sea birds the island is very white in appearance and is readily distinguished at a great distance. There is plenty of water close up to it on all sides, and vessels can pass between it and the beach or the group of rocks off the bluffs. These rocks, about 5 feet high, lie $\frac{1}{2}$ mile west of the bluff, and only about $\frac{1}{5}$ mile off the beach. The country back of the beach at this point rises into low woody hills, which rise into the mountains of Juluapan, lying on the NW. side of Manzanilla bay.

Manzanilla, Santiago, and adjacent bays.-Between punta Carrizal, on the west, and punta de Campos and Sail rock, on the east, are the bays of Carrizal, Higeras, Santiago, and Manzanilla. The largest and most important, Santiago and Manzanilla, are only separated by a small, narrow projection of the coast called punta de Santiago.

Santiago bay is about $1 \frac{3}{4}$ miles wide and deep at its narrowest part, and Manzanilla bay about $2 \frac{1}{2}$ miles wide by $1 \frac{1}{2}$ miles deep.

In standing in for Manzanilla you have the following excellent landmarks, viz: Pïedra Blanca (White island) and cerro Juluapan (Table mountain), with Wreck cone on the west; and Vigia Grande, with its projecting peninsula, and Sail rock off of it on the east of the entrance of the bay.

Cerro Juluapan or Table mountain, a very remarkable table-topped mountain, rises from the shore $\mathrm{N} W$. of Santiago bay. It is 2,620 and 2,790 feet high, the outer or seaward end being the lower. It is seen as a tabletopped mountain from the westward or eastivard, but from the southward the ends are nearly in range.

Wreck cone, a conical-shaped single peak, about 1,500 feet high, lies nearly SW. 3 miles from the inner end of Juluapan, and about midway between it and the Piedra Blanca.

Vigia Grande is a cone-shaped peak about 700 feet high, westward of Manzanillo and overlooking the town.

From the eastward it appears as the inner hill of what appears as a cape. From the westward this peninsula looks as if there was a cut through the 
middle. This is called "Las Ventanas," and is not visible from the eastward when close in to the beach.

Vigia Chica is the lookout station for Manzanillo. It is about 220 feet high and situated close under and to the northward of Vigia Grande.

Sail rock, so called from its appearance when seen at a distance, is about 112 feet high and lies $\frac{1}{4}$ mile off punta de Campos. It has several detached rocks, from 5 to 10 feet high, off its south face, and one black rock about 20 feet high about one-third of the way between it and punta de Campos.

Passage.-A vessel can pass between the point and this rock, but it is not recommended to do so. There is deep water outside and close to the rock, and no hidden dangers except those shown on the chart. Vessels bound in or out can pass within $\frac{1}{4}$ mile of all the bluffs from Sail rock to the anchorage, the sunken and detached rocks being iudicated on the larger charts.

Los Frailes. - Lying in the western part of the bay, $2 \frac{4}{5}$ miles from punta Carrizal, are seven small detached rocks from 5 to 20 feet high. 'These rocks may be passed close to on either side, there being deep water close alongside of them.

Pelican rock, off punta de Santiago, is of a whitish color and 72 feet high; it is $\frac{1}{4}$ mile in circumference.

Directions. - After making out either of the landmarks for Manzanilla bay and getting off the entrance, no sailing directionsare necessary, as you have but to stand in through a clear open bay to your anchorage, all dangers showing themselves well above water.

Capt. W. H. Parker says : "In making Manzanillo from the westward it is better to get hold of 'Frailes', then Navidad head, Graham head, and White island, passing about one mile from these points. The outlying danger is the Sister rocks (Los Frailes). If very dark or thick, you can easily make sure of avoiding these rocks by keeping over toward the starboard shore ; run 5 miles from the White island, then haul up; bring the Sugarloaf (Vigia Chica) on your starboard bow; as you pass this close to you will open the lights of the town. Should there be no light on the buoy, you will find it by steering about S. $65^{\circ}$ E. (S. $73^{\circ}$ E. mag.) directly for a high peak with which the buoy is in line.

Bound into Manzanillo from the eastward, you should pass Tejupan point at a distance of 2 miles, and verify your position by taking the time when Black head is abeam. You have then but 42 miles to run to Manzanilla point, and there is nothing to excuse your rumning by the harbor. Mauzanilla point is a bluff headland, and you will be sure to see it if you keep close enough to the shore. Sail rock will make out to the left of the point, unless you are set off, in which case it will be on with the point and can not be seen. Pass $\frac{1}{3}$ mile from the rock and point, and follow the land round with a port helm to your buoy. It is all a bold shore." 
Anchorage.-The anchorage is immediately under Vigia Grande, about $\frac{1}{4}$ mile from the village beach, in 9 fathoms of water. It was considered safe with all winds, except gales from the southward and westward, but in October, 1881, Manzanillo was visited by a terrific hurricane, commencing at east and SE. and veering to the south and SW. When in the eastern quarter it tore off the roofs of all the houses, uprooted trees, and drove ashore every vessel in the harbor. During the dry season the bay is safe; but this is the most unhealthy season of the year. Fever and ague prevail at all times, but are more fatal during the dry season. It is recommended not to lie here more than three or four days at a time, and to take an offshore berth in 15 fathoms, where you can get the full benefit of the sea breeze during the day and lessen the stench from the lagoon at night. Allow the crew or officers to land or be exposed in hoats as little as possible. and under no circumstances take water on board from Manzanillo. If water must be had, get it from Santiago.

Manzanillo, a town of about 1,000 to 1,500 inhabitants, is of importance only as the seaport of Colima, and as the terminus of the Manzanillo and Laredo railroad, and is growing in size and importance. There are no wharves, vessels loading from or discharging into lighters, but the railroad company propose building one so that that vessels can lie alongside and load or discharge their cargoes.

Behind Manzanillo there is a large stagnant lagoon filled with dead and dying vegetable matter, which renders this locality unhealthy and malarious and the stench (bilge water) is almost unbearable at night, carried out beyond the 15 -fathom anchorage by the land breeze.

Supplies of beef and vegetables, as well as other necessaries, can be had here, but, as before mentioned, fresh water should on no account be received on board.

Steamers._The Pacific Mail Company's steamers call here once a month.

Imports-Exports.-It imports coal, machinery, dry goods, etc., and exports cedar, brazil-wood, indigo, coffee, etc.

Port charges.-Tonnage dues, $\$ 1$ per ton; pilotage, $\$ 3.50$ per foot, but not compulsory; bill of health, $\$ 4$.

Tides. - The tides occur twice in 24 hours; spring rise about 6 feet; ordinary rise from 3 to 4 feet.

Currents. - During the survey the current from Manzanilla bay to cape Corrientes was found to be variable in force, but always setting alongshore to the northward and westward, stronger into the land than off shore, and increasing in force as the cape is approached. Sometimes no current would be noticed, then near the full and change nearly 2 knots per hour to the northward and westward. 
(Of currents off this coast Capt. Parker says:

"Between cape Corrientes and Manzanillo in August, N W., 1.() knot; in April between lat. $19^{\circ} 13^{\prime}$, long. $104^{\circ} 30^{\prime}$, and lat. $21^{\circ} 03^{\prime}$, long. $107^{\circ}$ $25^{\prime}$, N W. ., $\frac{1}{2}$ knot."

Colima.-From Manzanillo N. $72^{\circ}$ E. (N. $64^{\circ}$ E. mag.) and 35 nautical miles distant is Colima, the principal city and capital of the State of the same name, with a population of about 26,251 .

It is handsomely built, and like Sacatula on the coast, was founded by Cortez. The climate in this valley is very hot; the soil, however, is very productive. The vegetation consists of palms, aloes, and superb orange trees; and above the usual level these tropical plants are replaced by forests of somber pines.

Volcano of Colima, 12,290 feet high, lies N. $21^{\circ}$ E. (N. $13^{\circ}$ E. mag.) and $17 \frac{1}{2}$ miles distant from the city, and is the western extremity of the volcanic chain which traverses Mexico from east to west. Little is known of the volcano beyond the few facts obtained by Don Manuel Abad, vicar of the Bishopric of Michoacan, and while it frequently throws out smoke and ashes, no violent eruption has taken place for a very long period.

Safa volcano.-About $3 \frac{1}{2}$ miles north of the volcano of Colima there is the extinct crater of volcano de Safa, 14,610 feet above the sea. Its summit is usually covered with snow, and it, with the volcano of Colima, may be seen from a great distance at sea, and offers, when the atmosphere is clear, an excellent landmark for navigators approaching Manzanillo.

Coast.-From punta de Campos to Black head, distant about 43 miles, the shore line is a gray sand beach, upon which the sea breaks heavily. Anchorage can be had anywhere off the beach, except directly in front of mouth of the Cayutlan lagoon, whence extending directly out to sea there appears to be a submarine valley, as will be noticed by inspecting the soundings on the chart.

Cayutlan lagoon, separated from the sea by a narrow strip of low land on which runs the railroad from Manzanillo, extends for 18 miles inside and parallel to the shore line.

Rock.-At $25 \frac{1}{2}$ miles from Sail rock and 18 miles from Black head lies a rock only 5 feet above water. It is about one mile from the beach, and has 15 to 20 fathoms close to it on all sides; it is the only known danger between the two points, and lies inside the line joining them.

Rio Pascuales._About 5 miles N. $18^{\circ} \mathrm{W}$. (N.26 $6^{\circ} \mathrm{W}$. mag.) from Black head, and marked by a line of breakers extending out about $\frac{1}{2}$ mile from it, is the mouth of the rio Pascuales. A hut stands on its east bank. Vessels sometimes load here with dyewoods.

Black head juts out from the mainland, and has the appearance of an island when first seen from the westward or eastward. It is a cliffy peninsula, 560 feet high, densely wooded from base to top, and connected 
with the higher wooded hills on the mainland by a low sandy neck of land $\frac{1}{2}$ mile wide. A small white rock, 75 feet high, lies $\frac{1}{5}$ mile from the northwestern side of the head. An excellent anchorage in 10 fathoms may be found $\frac{1}{4}$ to $\frac{1}{2}$ mile inside of this rock and about $\frac{1}{2}$ mile from the beach. Boats can land on the beach, but there is nothing to be found here. Vessels can pass within $\frac{1}{4}$ mile of Black head, deep water being found close up to it.

Coast. - From Black head the coast breaks away and trends SE. by E. for 12 miles to the mouth of the $\Lambda$ pisa river. Three and a half miles from the head the sand beach is broken by a short line of rocky bluffs; and 2 miles to the westward of the river extend a line of cliff-faced bluffs backed by a shore range of hills 1,440 feet ligh.

The mouth of the Apisa is surrounded by a narrow line of breakers; the river seems to be a large stream extending back between two shore ranges. Midway between Black head and Tejupan point, about 4 miles back from the beach, is a remarkable table-topped mountain. It lies in an east and west direction ; its top is almost level, the seaward end being 4,030 feet high and the inner end $3,7.18$ feet.

From the mouth of the A pisa the coast trends SSE. for $6 \frac{1}{2}$ miles to Tejupan point. Three-fourths of a mile SE. of the river begins a line of low white rocks, 5 to 12 feet high, and extending nearly 2 miles. Two miles west of Tejupan point a dangerous shoal and reef makes out from the shore more than a mile, its locality being marked at most times by the breakers on it. A line from Black head to Tejupan point barely clears the reef, and vessels from the westward standing into an anchorage under Tejup:n should be particular not to get inside of the line. Between the inshore end of the reef and Tejupan point there is a line of low bluffs separated from each other by small sand beaches.

Tejupan and San Telmo points, from either the westward or eastward, look like one projecting point; from the westward Tejupan apparently projects most; from the eastward San Telmo seems furthest out, and when directly abreast of them there is no point visible, both being in appearance a series of rocky bluffs. Tejupan is the most prominent of the two, owing to the three rocky islets that lie S. $79^{\circ} \mathrm{W}$. (S. $71^{\circ} \mathrm{W}$. mag.) for $\frac{3}{5}$ mile. The outer one is a black rock about 20 feet high and only a f'ew yards across ; the middle islet is 40 feet high and about $\frac{1}{5}$ mile long, whilst the inside one is 60 feet high and about $\frac{1}{4}$ mile long. Each one is surrounded by sunken and detached rocks, which renders landing difficult and a near approach dangerous. There is an anchorage to the NIV. of these rocks in 12 or 15 fathoms of water, with a low stone pile on the middle islet bearing S. $45^{\circ}$ E. (S. $53^{\circ}$ E. mag.) ; there being but little shelter from southeasterly winds, this anchorage is not a good one.

Caution.-During the daytime Tejupan point can be passed close to, but at night a good berth should be given it on account of its lowness and the variable current setting along this part of the coast. 
San Telmo.-There is nothing remarkable about San Telmo point. The same caution that was given for passing Tejupan at night applies here, but during the day ressels may pass close to the rocks and bluffs.

Capt. Parker says:

"Point 'Tejupan is low with several large rocks or islets off it. Vessels frequently anchor here in the dry season close inshore, and inside of the islets. You can pass the point at a distance of 2 miles and then shape your course for morro Petatlan. As it is sometimes difficult to make out point Tejupan at night, I have found it necessary to take a departure from White Rock point, which lies 10 miles further to the eastward and is more readily distinguished by the rocks lying to the ESE. of it."

Coast.-Between Tejupan and San Telmo the shore line is of rock bluffs, with short white sand beaches adjoining each point. At San Telmo the coast line changes its direction and trends ESE. for $8 \frac{1}{4}$ miles to the Piedra Blanca of Maruata, the White Rock point of old charts.

For $2 \frac{3}{4}$ miles the shore line is a succession of rock bluffs and sand beaches, which end in a remarkable sugarloaf rock 75 feet high ; then follows a white sand beach $2 \frac{1}{2}$ miles long, where it meets the low bluffs 3 miles west of Piedra Blanca. These bluffs, increasing in height to Maruata, are separated by sand beaches.

Piedra Blanca, lying only a few yards off the south side of the bluff, is a white rock 110 feet high and about $\frac{1}{4}$ mile in circumference, and, taken together with the white bluffs back of it on the shore, forms the best landmark for Maruata bay, which lies $\frac{3}{4}$ mile to the eastward of the bluff. 'The bluffs show white to the eastward and are the first high white bluffs to the eastward of San Telmo point.

Maruata bay is exposed to all winds except those from the northward and westward. On the west side of the bay lie four small rock islets in a line from east to west, off the point extending about $\frac{1}{5}$ mile. The shore line of the bay is a white sand beach, and the rocky islets with a rock bluff at the end of the beach form the west limits of the bay.

Anchorage, landing.--The anchorage is in 7 fathoms of water, sand over mud bottom, with the easternmost of the four isles bearing $\mathrm{N} .76^{\circ} \mathrm{W}$. (N. $84^{\circ} \mathrm{W} . \mathrm{mag}$.) and about $\frac{3}{10}$ mile from the beach. A native hut stands in a grove of cocoanut palms back from the main sand beach. Although boats can land on the western end of the beach, it is better to pass outside and to the southward of the islets and land on the short sand beach to the westward of them, where the water, being out of the heavy swell which sets into the bay, is moderately smooth.

Supplies.-Vessels sometimes load here with dyewoods, but no supplies of any kind can be obtained. Water can be had from the lagoon which empties into the western end of the bay, but it should not be taken on board except in case of neccssity. The Mexican Government has tried. 
three times "to open" Maruata to trade by establishing a customhouse here, but each set of officials having died of the local fevers and diseases, etc., the attempt has been abandoned; it is without doubt the most unhealthy place on this coast.

Paps of Tejupan.-These should be called the paps of Naruata, being nearer to that place than to Tejupan point. They are at the summit of a range about 5,600 feet high and not well defined as "Paps." From a vessel to the eastward or westward of them a double-nipole sumnit appears, the northernmost one being wooded to the top, while the other is alnost bare. They are not distinctly seen from the south ward, as they are then overshadowed by the more lofty ranges back of them, which rise to an elevation of 9,(000 feet above the sea. A smooth wooded cone 2,140 feet high is remarkable when passing this part of the coast. It is $3 \frac{1}{2}$ miles northeastward of the anchorage at Maruata.

Coast.-For 3 miles eastward of Maruata extends a line of high and bold-faced bluffs, backed by woody hills. A low rock reef extends for $\frac{1}{4}$ mile in a southwesterly direction off the next to the end bluff. A sand and shingle beach succeed these bluffs for $3 \frac{1}{2}$ miles, where begins a high and remarkable bluff line extending 6 miles to Pichilinquillo bay. This last bluff line is broken by 3 or 4 projecting points with detached outlying rocks off of each, but from Tejupan to Lizard point the water is deep close to the bluffs and a vessel can pass within $\frac{1}{2}$ mile of each one. All dangers show themselves above water in low outlying rocks. Westward of Pichilinquillo, $2 \frac{1}{2}$ miles, the bluffs are vertical and overhanging, from 50 to 120 feet high ; the sea faces of them are pefectly smooth, and a vessel might brush against them, the water being deep and free from danger clnse to their bases. Near the center of these vertical bluffs a small stream flows over the face of the cliff, leaving a yellowish white deposit, which shows a long way to sea.

The whole country between Maruata and Lizard point, which is broken, mountainnus, and densely wooded, rises in successive ranges until an elevation of 9,000 feet is reached 15 or 20 miles inshore. About 5 miles to the westward of Pichilinquillo are two small sand beaches between the bluffs where fresh-water streams empty into the sea.

Pichilinquillo bay lies to the westward of Lizard point, with a white sand beach at the bottom. It is open to all southerly winds, yet it affords good anchorage for small roasters. Large vessels can anchor in 9 or 10 fathoms, sand bottom, on a line from the islet to Lizэrd point; smaller ones can go into 5 or 6 fathoms $\frac{1}{4}$ mile from the sand beach and find better shelter. Nothing in the way of supplies is found here; in fact there are no sigus of habitation any where near the bay. Three-quarters of a mile from the western side of the bay, and on a line with Lizard point, lies a 
rocky islet 100 feet high and about $\frac{1}{2}$ mile in circumference. It is not easily distinguished as an island unless close into the coast.

Between this island and the sand beach inside of it are a great many sunken rocks, through which it would be difficult for a boat to pass. There are also two sunken rocks on a line between it and the bluff point on the west; one about half way, and the other close to the point.

Lizard point, which forms the eastern side of Pichilinquillo bay, appears from either up or down the coast as low, narrow, and projecting, but in reality it is a dark bluff headland, $1 \frac{1}{10}$ miles long on its sea face, and about 150 feet high, covered with thick woods.

There are several outlying rocks close to Lizard point, but a vessel may pass within $\frac{1}{4}$ mile of them.

Coast.-From Lizard point the coast trends E. by S. for $25 \frac{1}{2}$ miles to a low rock-facerl bluff, and not remarkable point, that projects $\frac{1}{2}$ mile beyond the general bluff' line. 'There are many low outlying detached rocks off these bluffs, but all are close in and out of the track of passing ressels.

Bufedero.-Three miles west of this low point there is a reddish bluff with a "Bufedero" in it, which sends up a jet of water or spray, forced by the sea through the crevice of the rock below, that resembles the spouting of a whale.

Landing.-At $6 \frac{1}{4}$ miles to the eastward of Lizard point, a fine, rapid current empties in the sea on the east side of a low shingle point of the beach. A palm grove stands on the west bank and the landing for boats is fair when no sea is running.

Coast.-At $18 \frac{1}{2}$ miles east of Lizard point is a remarkable peak when seen from up or down the coast. It is sharp at its summit, 1,443 feet high, and descends in a long saddle like slope to the outer extrenity of the ridge which terminates in a decided point knob 960 feet high. The highest peak is $\frac{9}{10}$ mile back from the shore line, which is here a low bluff $\frac{9}{10}$ mile long. From the outer peak or knob, a gentle slope falls to the shore line and the low extreme point, 7 miles to the eastward, shows as a prolongation of the slope, which appears at a distance from up or down the coast as a low point extending out from the knob. There is a large river, with a line of breakers across its open mouth, lying between this knob and the Bufedero bluff.

From the extreme bluff point, $3 \frac{1}{4}$ miles east of Bufedero, the coast line trends about east for $11 \frac{1}{2}$ miles to the end of the bluff line and the commencement of a long, unbroken sand beach extending around Mangrove and Sacatula points.

Along this coast are frequent high-water breaks, indicating mouths of streams during the rainy season. There are many detached rocks off the little bluffs, but they are close to the beach, and may be approached to * 
within $\frac{1}{2}$ mile without danger. The country back of this coast is rough and mountainous.

Anchorage.-Vessels may anchor anywhere off the sand beach in from 10 to 15 fathoms, $\frac{1}{2}$ to $\frac{3}{4}$ mile from the shore; the sea breaks heavily all along the beach.

Calpica village is $5 \frac{1}{2}$ miles down the beach from the end bluff, with two small groups of huts between it and the bluffs. About 9 miles from Mangrove point is another village of 15 or 20 huts, on the east side of the closed mouth of a lagoon.

Mangrove point is called a bluff on some of the old charts, but it is a low, round point 20 to :30 feet high, formed by the change in direction of the shore line. It is covered with mangroves and palms, and near the point with dead trees and brush. There is nothing to mark this locality, as the country back of it is low and flat, forming the delta of the Sacatula river.

Sacatula point.-This double or rounding point is formed by Mangrove and Sacatula points, distant from each other 3 miles N. $68^{\circ} \mathrm{E}$. (N. $60^{\circ} \mathrm{E}$. mag.) Sacatula point is near the principal mouth of the river of the same name, and is the northeastern projection of the delta, while Mangrove point is the southern.

Sacatula river is a large stream which rises in the mountains near the city of Mexico, and empties into the sea through three mouths, the first and largest being near Sacatula point, the second 6 miles west, and the third 8 miles west of Mangrove point. This river is known to the natives under three different names, viz, Sacatula, near its mouth or in the delta; Balza, from the head of the delta for some distance inland, and the Mescal thence to its headwaters. Instead of being "very small," as was supposed by Capt. Richards, R. N., it is one of the longest and largest rivers in Mexico. "During the rainy season an immense volume of water is discharged into the sea, discoloring the surface some 8 or 10 miles off shore.

The soundings off this particular part of the coast, that is, off the delta of the Sacatula, are very irregular and extend 5 miles off shore; the bottom is of shifting sand and discharged mud.

Anchorage.-Vessels can anchor anywhere off this beach, the deeper and safer water being to the westward of Mangrove point. There is no landing in either of the mouths of the Sacatula.

Petacalco bay.- In this bay, as to the southward and eastward of it, the bottom is very uneven and lumpy. Vessels should approach the shore with great caution, as the bottom is shifting and the soundings on the chart, close in, are not reliable for any length of time.

Canuta.-There is an excellent boat landing at this place, but nothing in the way of supplies can be obtained. 
Coast.-From Canuta the coast trends southeastward 2:3 miles to punta Troncones, a low, cliffy headland 540 feet high, rising to a peak back of it 1,145 feet. The beach is low, covered with palms and cocoanuts, and broken in a number of places by small streams which drain the adjacent country during the rainy season. The water is deep close to the beach and anchorage can only be had in Salada bay, $1 \frac{1}{2}$ miles west of punta Troncones. From this point the coast trends SE. $8 \frac{1}{2}$ miles to Istapa bay.

Isla Grande(Istapa) bay. - An excellent harbor of refuge is formed by Isla Grande and the mainland and protected from all winds except those between WSW. and WNW., from which direction the wind seldom or never blows. About a mile to the northward of the bay is the Rincon, which, like Sacatula and most other rivers in Mexico, is closed by a bar with heavy breakers on it; but boats can cross this bar without much danger by selecting a smooth time. A small Indian village lies about 5 miles up the river, where an excellent quality of fresh beef can be had, but no other suipplies.

A sunken rock lies in the bay and about $\frac{1}{2}$ mile N. $6^{\circ} \mathrm{W}$. (N. $14^{\circ} \mathrm{W}$. mag.) of Isla Grande, and has only 5 feet of water on it at low water; with a heavy swell and at low. water it breaks, but at other times it does not show. By keeping close to the rock off Isla Grande, say 400 yards, this danger may be easily avoided; then stand into the anchorage, being governed by the draft of the vessel and the lead line.

Anchor anywhere after passing a line from the outer rock to the Rincon river, but the deepest water is near Isla Grande. There is a free passage between Isla Grande and the mainland, all dangers showing above water.

Isla Grande (Istapa) is a small, irregular-shaped island, about 170 feet high, and $\frac{1}{5}$ mile from the mainland. It is thickly covered with brush and undergrowth. When seen from the offing it has not the appearance of an island, but looks more like a headland on the mainland.

Istapa peninsula, one mile. SSE. of Isla Grande, and 200 feet high, heavily wooded, may easily be mistaken for an island, as it is separated from the mainland only 50 feet, and connected with it by a narrow land strip about 3 feet above the water. This peninsula forms with Isla Grande an open bay to the southward, and anchorage can be had here in 6 fathoms, but the bay is not so good as Istapa.

San Juan de Dios bay is to the eastward of Istapa peninsula, but it is foul, being cut up by a group of rocks or islets called Islas Blancas.

Islas Blancas are six or eight detached rzcks from 20 to 150 feet high, the eastern one being the largest, not $\frac{1}{4}$ mile in circumference, and quite square in shape. They are very conspicuous from the offing, particularly when the sun is past the meridian. When seen with the sun shining on them they have a white appearance, but at other times, or on an "overcast" day, the name "blancas" is a misnomer, as they are dark brown in color. Vessels can pass within $\frac{1}{4}$ mile of them in safety. 
Coast.-Isla Grande is the westernmost elevated ground in the immediate vicinity. The coast to the eastward is bold and rocky, the bluffs coming down to the water. About 4 miles from the peninsula is the first bluff point; 2 miles from it is the second and one mile from the second is the third bluff, and $\frac{1}{2}$ mile from this is still another, then the rocky beach breaks away to the uorthward and eastward, about 2 miles to the sand beach.

Sihuatanejo harbor lies between the second and third bluffs and is a small but excellent harbor, free from all dangers and easy of access, with deep water close to the rocks on either side of the entrance. The harbor is open to all winds from the SW., but you can anchor any where inside the bay, making allowance for the draft of the vessel and the heavy swell that sets in from the sea. The holding ground is good; the bottom is soft mud. The land all around it, except at the head of the bay, rises abruptly from the beach, the bluffs bearing NW. and SE. from each other, those on the east side being the higher.

Supplies.-Excellent beef and water can be obtained here, but no other supplies.

Black rock, 46 feet high, is one mile off the entrance to the harbor, and is the only good mark to the entrance of the bay. Between the rock and the entrance to the harbor the bottom is gravel and stone. Directly back of the harbor there are two remarkable peaks.

Directions. - Coming from the westward, after passing Mangrove point, steer about S. $65^{\circ}$ E. (S. $73^{\circ}$ E. mag.) 35 miles for Islas Blancas; pass outside of them, and as you get nearer you will easily distinguish Black rock. Coming from the southward, after passing morro de. Potoci or White Friars steer N. $37^{\circ} \mathrm{W}$. (N. $45^{\circ} \mathrm{W}$. mag.) for Black rock, leaving it on either hand. Pass on either side of the rock. You can go within 200 yards of it, there being from 5 to 10 fathoms within a boat's length of the break at its base. As you near Black rock from the southward the sand beach to the right and in the harbor can be seen, but the huts at the head of the bay do not show until quite well in.

Remember that Black rock is the mark for this harbor, and without getting hold of it there may be trouble in finding Sihuatanejo, while with it close aboard one can not miss or mistake the entrance.

Morro de Petatlan, about 640 feet high and $\frac{1}{2}$ mile in diameter, is a round hill jutting out into the sea, and is densely covered with bushes and straggling trees. The morro at a distance, either east or west, appears like an island. It is connected with the mainland by a narrow neck of land thickly covered with undergrowth. Around the point to the northward and westward is the bay or roads of Petatlan, affording anywhere an excellent anchorage, with shelter from all winds except those from the SW. to NW., according to the draft of the vessels, in 9 and 10 fathoms just inside the point, hard sand bottom, shoaling gradually to the beach. On the north 
side of the morro is a straight and abrupt shingle beach ; at the end of the shingle, and the commencement of the sand beach, there is an excellent boat landing; at the head of the bay is a salt lagoon. There is an abundance of very good edible fish in the lagoon, but there are no supplies to be had, nor is there any fresh water in this vicinity.

Petatlan can be approached within $\frac{1}{4}$ mile, as the water is deep close to and all rocks and dangers show themselves.

Morro de Potoci or White Friars, lying $1 \frac{1}{2}$ miles west of morro de Petatlan, are seven or eight barren rocks or islets. Four of these are quite high (50 to 80 feet) and large; the remaining are small rocks. There is an excellent passage between the rocks and Petatlan, with the deeper water nearer the rocks, which have deep water close to.

Coast.-From Petatlan the beach trends about ESE. in an unbroken line for 17 miles to Japutica point. This unbroken sand beach is low, covered with bushes, palms, and cocoanut groves. The land back is cultivated and rises to the mountain range, 10 miles from the beach, to an elevation of from 2,000 to 4,7 0 feet.

Japutica point, low, black, and rocky, is easily recognized, as it is the only rocky projection on this immediate coast. To the northward and westward of Japutica the coast recedes a little and vessels may anchor here. About a mile east of Japutica point there is a remarkable sand patch 300 yards back from the beach and extending up the bank 75 to 100 feet; it is bright, clear, free sand, surrounded by bushes, and a little to the eastward of it is a large cocoanut grove. The water is deep close in to the beach, but breakers have been seen off the extreme point of Japutica during a heavy blow, although no hidden dangers at any distance from the rocky beach have been found.

From Japutica the sand beach continues in a gentle curve for 9 or 10 miles to Tequepa point or morro de Papanoa.

Morro de Papanoa or Tequepa is a bold, rocky headland 527 feet high, densely covered with brush and small trees. There are several detached rocks off its western face, but to the southward it is bold and clear and a vessel can pass within $\frac{1}{4}$ mile of the beach.

Tequepa bay.-Punta de Papanoa is the extreme west point of this headland. To the northward and westward of Papanoa or Tequepa is Tequepa bay, which has excellent shelter from all winds except those between SW. and NW. A good boat landing is found at the head of the bay, but neither water nor supplies of any kind can be obtained.

Morro de las Animas, a large white rock with several smaller rocks around it, lies 2 miles north ward of the extreme point of Tequepa. Animas is fanshaped, opening to the north ward, about 112 feet high, the highest part being at the south point. There is a clear passage, with 3 and 4 fathoms water, between Animas and the main. 
Coyuquilla river is about $3 \frac{1}{2}$ miles N. $15^{\circ} \mathrm{W}$. (N. $2: 3^{\circ} \mathrm{W}$. mag.) of Tequepa and to the westward of Animas rock. The small stream 9 miles east of Tequepa is the San Luis river, which breaks through the beach only during the rainy season. The land back of 'Tequepa is very high and thickly wooded.

Coast.-To the eastward of Tequepa are three bluffs or projecting points ; the most eastern is 3 miles from Tequepa, the commencement of the long sand beach to Acapulco. The sand beach trends ESE. without interruption, except in rainy season, when streams break through, for 70 miles to the head of Acapulco. The beach is from 10 to 15 feet high, crowned with a heavy undergrowth of bushes, interspersed with palms and cocoanuts. The land back of the beach is low and cultivated, then rises in successive mountain ranges until it attains a height of 12,000 feet, back of the paps of Coyuca, and 28 miles from the beach.

Between Tequepa and the heads of Acapulco a vessel can approach the beach to within $\frac{1}{3}$ mile, and anchor anytwhere in from 10 to 15 fathoms of water about $\frac{1}{2}$ mile from the line of breakers, just outside of which is 6 fathoms of water. Boat landing is almost impossible on this beach, as there is always a very heavy surf.

Paps of Coyuca is a remarkable double-coned mountain, in lat. $17^{\circ} 23^{\prime}$ N., long. $100^{\circ} 05^{\prime} 30^{\prime \prime} \mathrm{W}$. These cones or "paps" lie in a NW. and SE. direction from each other, their summits or apexes being separated by only about a mile in a horizontal line. The northwestern is 10,594 feet high, and the other, or southeastern, only 10,474, while the height of the cones or paps above the mountain proper is about 1,200 or 1,500 feet, the northern being the higher. Owing to the height of this mountain clouds settle over it, and the paps are seldom seen, particularly near and during the rainy season. During this time all of these high ranges are covered with clouds; early in the morning they are clearest.

From the lighthouse on Grifo islands the paps bear N. $15^{\circ} \mathrm{W} .\left(\mathrm{N} .23^{\circ} \mathrm{W}\right.$. mag.) distant 35 miles, and from Tequepa point they bear about $\mathrm{N} .83^{\circ} \mathrm{E}$. (N. $75^{\circ}$ E. mag.) distant 56 miles. To the northward and westward of the paps, and nearly 30 miles from the beach, is a remarkably high range of mountains, some of which have an elevation of 12,000 feet.

Directions.-Capt. Parker states as follows:

"Having passed morro Petatlan (and the seven remarkable white rucks lying off it) steer to pass one mile from Tequepa point, which lies in latitude $17^{\circ} 17^{\prime} \mathrm{N}$. longitude $101^{\circ} 01^{\prime} \mathrm{W}$.; thence S. $67^{\circ} \mathrm{E}$. (S. $75^{\circ} \mathrm{E}$. mag.) will carry you along the beach to Grifo island. This beach extends without interruption to the heads of Acapulco.

Twenty-nine miles from the buoy in Acapulco harbor is a low bluff (with high land back of it coming nearly to the beach). A grove of cocoanut trees to the westward of it and a few huts a mile or so to the eastward. 
Further on, 18 miles from the buoy, is a ridge and conical peak, (high land back of them) with a village to the eastward and probably a river. If you will take an opportunity of making out these marks in the day you will find them easily recognized afterwards at night, and of great assistance to you when running for the harbor in the rainy season.

Having passed Grifo island, at a distance of $\frac{1}{\ddagger}$ mile, you have only to follow round to the left into the harbor." (H. O. chart 933 gives the south point of Tequipa as in latitude $17^{\circ} 15^{\prime} 30^{\prime \prime} \mathrm{N}$. and longitude $101^{\circ}$ $04^{\prime} 40^{\prime \prime} \mathrm{W}$.)

Acapulco harbor is considered the finest in Central America or Mexico, and, for its size, one of the most complete in the world. The bottom is sand, but clay beneath, and affords good holding ground.

All around the harbor are high mountains, which afford considerable shelter to the harbor, and may be seen a great distance at sea.

Roqueta or Grifo island lies just outside the port, at its western entrance. It is 350 feet high and irregular in shape. Its eastern and western extremities have each a reef extending seaward nearly 300 yards, parts of which are above water; in other respects the island is clear of any known sunken dangers. At $\frac{1}{8}$ mile from the island there is a small islet or rock, 50 feet high, named El-Morro, outside of which is a depth of 15 fathoms. At $\frac{1}{3}$ mile eastward of El Morro is a rock 5 feet above water and having a depth close to of from 10 to 12 fathoms. Its position is a dangerous one, coming from the westward. There is no passige between it and Grifo, as the sea always breaks over it and it is well marked by day.

Light.-From the summit of Roqueta or Grifo a fixed white light is shown, which should be visible from 15 to 20 miles. This is only lighted when the mail steamers are expected or leaving the harbor.

Boca Chica, between Roqueta and the main, is $\frac{1}{8}$ mile wide in its narrowest part. Vessels using this channel have only to keep clear of the rocks that show; there is no hidden danger.

Boca Grande, between Roqueta and Bruja point, is also clear of danger, except the rock before mentioned, between which and Bruja point there is a passage over one mile wide.

Serieuse shoal.- There are no dangers in Acapulco harbor except this shoal or rock in the northern part of the bay. It is 1,100 yards $\mathrm{N} .79^{\circ}$ E. (N. $71^{\circ}$ E. mag.) from the fort, and has 15 feet of water on it. It was discovered by the French ship Sérieuse striking on it, and lies on a line between fort San Diego and the Obispo rock. San Lorenzo rocks lie between these, and are a short distance from the shore, between which is no safe passage.

Acapulco is situated on the low ground at the western end of the harbor, is poorly built, only a few of the houses having more than one story. There 
is one large church, a fair market house, and a small plaza or garden near the center of the town.

It has a population of about 5,000 , mostly of mixed blood, the Indian and negro races predominating. There are a few Europeans, who carry on most of the exporting and importing trade of the place.

Acapulco was at one time subject to severe earthquakes, but of late years they have been few and not very destructive. The rainy season, also a great drawback to the prosperity of the town, and very severe, commences about the end of June and lasts until the end of October. Owing to the immediate vicinity of a lofty chain of mountains that overlook the town the fall is heavy and almost incess int. During this period the inhabitants are compelled to use every precaution to keep their houses dry, particularly the floors; a neglect of this is supposed to produce fever.

During part of the dry season the air is filled with a putrid effluvia from a morass to the eastward of the town. This, together with the heat of the sun's rays on the granite rocks which environ the town, renders it very especially unhealthy to Europeans. A cut has been made in the rocks to the westward of the town to let in the sea breeze, which has tended to improve its salubrity. The heat during the latter part of the dry season becomes intense, the thermometer rarely falling below $98^{\circ} \mathrm{F}$; w water becomes scarce and the streams running dry; it is then necessary to depend upon wells for water; this is not always good. There is no system of underground sewerage, but of late the town has beeu kept quite clean by sweeping the streets and attending more carefully to the police of the town. Acapulco rarely escapes a visit of pernicious fever once a year ; this usually comes during the latter part of the rainy season. The harbor is infested with man-eating sharks.

The United States is represented by a consul and vice-consul.

Supplies.-The market is well supplied with fresh provisions, and fruit is excellent and abundant. No naval stores of any kind can be obtained. Fresh water of a good quality is found at several points between the fort and Obispo rock, but the best streamsare between the fort and San Lorenzo. Ships can now be supplied with water from a water boat fitted for the purpose; this water is taken from a well in the town, and is of fairly good quality.

The customhouse is at the water's edge, near the short sand beach in front of the town, where all imports other than coal must be landed. The captain of the port visits all vessels entering the harbor, and has control of all loading and unloading. Nobody is allowed to work in boats, lighters, or vessels except the men of the IIricicula of the port, under the immediate command of the captain of the port. A vessel having 1,800 tons of coal discharged it in thirty days.

$11562-11$ 
Dues.-Tomnage on foreign vessels, $\$ 1$ for each cubic meter (about 35 cubic feet, English measurement). Use of hoisting engine, 25 cents per ton. Bill of health, \$t. Harbor fees, $\$ 6.50$. Water, per gallon, 1 cent f. o. b. Ballast, f. o. b., $\$ 1.75$ per ton. Steamers as well as sailing vessels bringing coal are exempt from the payment of tonnage fees.

Telegraph. - There is telegraphic communication to all points.

Mail.-The mail leaves every day for the interior and the city of Mexico. The Pacific Mail Steamship Company's steamers call here to take coal and exchange freight with the coastwise steamers of the same line four times every month, twice going and twice coming. They take the mails for Panama, San Francisco, and intermediate ports.

Coal of good quality can most aliways be obtained. One of the merchants has a contract with the British government to keep constantly on hand at least 600 tons of Cardiff coal. There is usually 1,000 tons on hand.

Repairs. -The Pacific Mail Steamship Company maintains a small machine shop, where slight repairs, but no work of an extensive nature, can be done.

Pilots. - All vessels are signaled from the Vigia to the port, and pilots will go out to bring in vessels, but none cruise off the harbor. Pilotage, - \$1.75 per foot draft inward and outward. Pilotage compulsory.

Imports, manufactured goods and coal.

Exports, hides, wool, cotton, jndigo, cochineal, cedar logs, fruit, etc.

Anchorage.-The best anchorage is in Sta. Lucia bay, in front of the town. By anchoring in about 10 or 11 fathoms of water, and with fort San Diego bearing N. $11^{\circ}$ E. (N. $3^{\circ}$ E. mag.) distant $\frac{1}{2}$ mile, the vessel will be abreast of the low land called the Manzanilla, between the bay and the sea to the westward, and thus secure the benefit of the sea breeze, which blows across this neck of land. The sea breeze blows quite fresh from about 11 a. m. until after sunset. The land breeze comes from the northward and eastward during the night, but it is always very feeble, and dies out about sunrise.

The advantages of this berth may be further increased by running out a hawser to the rocks just north of the anchorage and bringing the ship broadside to the wind. There is a mooring ring in the largest of these rocks.

Port Marques._Between Bruja and Diamante points, just outside the eastern entrance, is a little bay of this name, with mud, sand, and rock bottom, where there is good shelter from all winds, except westerly, which blow directly into it.

Diamante point has a reef extending from it a short distance; there is also a small rock on the north side of the bay at about 200 yards from the 
shore, and at the head of the bay is a sunken rock; all these can easily be avoided.

Directions.-The heads of Acapulco are the only rocky projections breaking the sand beach from Tequepa point on the west, to Acamama point on the east, a total distance of nearly 140 miles. In making Acapulco from the SW. or south the entrance is remarkable from the yellowish cliff of Diamante point and Roqueta island, which can be seen at a long distance; the paps of Coyuca are also seen, but the eastern peak appears cut off. There is also a white woxden tower on the summit of Roqueta island used for a lighthouse. There can be no difficulty in making the harbor, as it is further pointed out by a lofty promontory, which maintains its height and abruptness to the sea. This high land is covered with trees and shrubs and everywhere presents a green surface; except where it meets the sea its face is laid bare, and shows only white and gray cliffs of granite, not of a massive character, but splintered in all directions.

Entering by the boca Grande a vessel can use Obispo rocks as a mark to lead in through mid-channel until nearly abreast Grifo point; then haul up for anchorage. As there is deep water close to the rocks near this point, and no outlying rocks, a vessel can pass very close to it.

Leaving Acapulco bound east, after passing the Potrero or Rodrigo rock, the rocky coast breaks away for $\frac{1}{2}$ mile or upwards, where it joins the sand beach. This beach continues uninterrupted (except where lagoons break through during the rainy season) for nearly 60 miles, to the rocky point of Acamama or the cerro del Coacoyal.

Caution.-About 15 miles from the Potrero is a low sandy point covered with green bushes with very heavy breakers off it. Owing to a current setting E. by S. off the heads of Acapulco and some distance east at from $\frac{1}{2}$ to 3 knots, therefore in leaving Acapulco bound to the southward and eastward, this fact, and that the current sets strong to the eastward, should be remembered, and if at night or thick and rainy do not steer higher than S. $48^{\circ}$ E. (S. $56^{\circ}$ E. mag.) until well clear of the point. This sandy point is extending year by year. The lagoon and river just east of it makes a great deposit that, with the wash of the sea, causes the point and shoal to grow.

During three seasons of surveying, Commander J. W. Philip, U. S. Navy, noticed a change in the astronomical bearing of the outer breaker from the lighthouse.

Papagayo lagoon or river is east of this sandy projection, with a bar across its mouth. During the rainy season and for a time after until the neighboring country is drained, this lagoon breaks through the beach and its discharge discolors the sea for miles off the coast, and is a good mark for the entrance to Acapulco, especially if you are close in shore and are without observations. Off this sandy point (west of the mouth of the 
lagoon), although there is a rery heary surf and breakers extend some distance out, the beach can be approached within a mile if necessary.

About 20 miles N. $28^{\circ}$ E. (N. $20^{\circ}$ E. mag.) of the mouth of this lagoon the remarkable Corcovado peak, mentioned by Capt. Parker, makes an excellent mark (when not obscured) for vessels from the east bound to Acapulco.

Nexpa village.-Twenty-two miles from this same lagoon is a small collection of huts on the beach, called the village of Nexpa, which, though small, is the largest along this coast. Just east of the village is the boca del rio de Nexpa.

Along this entire beach, which is low and sandy and erowned with low bushes interspersed with palms and cocoanut trees, a heavy surf breaks, and there is no boat landing. Inland the country, which is low and cultivated to the foot hills, rises to hills and mountain ranges from 1,200 to nearly 6,000 feet high.

Cerro del Coacoyal is back of Acamama point, and rises gradually from the beach. It is more of a mound than mountain, and has only an elevation of 626 feet.

Acamama point, low and rocky, with two or three detached rocks off and to the westward of it, ends the sand beach from Acapulco. There is a heavy line of breakers extending in a SE. direction for upwards of a mile off this point. In the extreme edge, or end of the break, 4 and 6 fathoms of water was found during the survey of this part of the coast by the U.S.S. Tuscarora. The surf breaks so heavily that the steam cutters could not go in to ascertain the depth, or whether it was rocks or a shoal that caused the breakers.

Soundings and anchorage.-Between Rodrigo and Acamama points anchorage can be had anywhere along the beach in 10 to 15 fathoms bottom, saud on top, and good holding ground.

Bay of Dulce.-From Acamama point the coast breaks away to the northward and eastward for 4 miles, then to the southward and eastward for $4 \frac{1}{2}$ miles to the Dulce river, forming what is called the bay of Dulce.

The Dulce river, on the banks of which lies the village of Tecoanapa, discharges large volumes of mud and water during the rainy season, which forms a shifting bottom off' its mouth; consequently soundings are irregular and changeable; a shifting bar across the mouth can only be crossed by boats or lighters at certain stages of tide and swell. There is 6 feet of water at low tide; rise and fall about 7 feet.

At the full and change of the moon there is always a heavy swell setting in from the SW., cutting. off all communication with the river and village.

Supplies. - There is excellent hunting and fishing up the Dulce, which can be ascended 15 or 18 miles, using ships' boats, or in canoes obtained 
at Tecoanapa. Beef of a fair quality can be had and water obtained well up the river; owing to the bar it will be difficult to raft ịt off.

Coast.-From the Dulce river the coast trends about SE. 14 miles in an unbroken sand beach to the Maldonado, off which about 3 miles lie the Tartar shoals.

Tartar shoals, the least known and greatest danger to navigation on this portion of the coast, lie off Maldonado point, or, better named by the native coasters, punta Escondido; this point cannot be made out from the westward, unless inside of N. $68^{\circ} \mathrm{W}$. (N. $76^{\circ} \mathrm{W}$. mag.), and in coming from the eastward disappears after passing the bearing $\mathrm{N} .23^{\circ} \mathrm{W}$. (N. $31^{\circ} \mathrm{W}$. mag.).

Within these limits are several shoal patches with rock, which constitute the dangers to navigation. This danger has been incorrectly reported on various. bearings and at distances of from 4 to 13 miles off shore.

To the westward of the 5 -fathom shoals the depth is irregular, being from 6 to 11 fathoms, but outside of 3 miles the depth increases gradually to 40 fathoms in a westerly rirectiou and 100 fathoms in a southerly direction.

At a distance of $1 \frac{4}{10}$ miles N. $70^{\circ} \mathrm{W}$. (N. $78^{\circ} \mathrm{W}$. mag.) from the point is the wreck of the steamer City of San Francisco on a shoal that is gradually growing by the action of the sea on the bottom. Heavy breakers extend $\frac{1}{3}$ mile outside of the wreck on a line with it and the point.

Caution.-Vessels in passing along this dangerous coast should use the lead diligently and not venture in less than 30 fathoms of water.

Punta Fscondido is seen only when close in to the beach. There is a small bight close around the point to the westward, where there is a good boat landing; and one mile from the landing to the northward and westward is an abundance of fresh water.

To the westivard of this point is a sandy beach, and for a distance of 6 miles is a series of sand bluffs from 200 to 300 feet high, with ravines between them, which are good landmarks at certain seasons.

To the eastward, for a distance of 2 miles, the coast is rocky, with 2 small breaks where there is a sandy beach; and within a distance of one mile from the point are several sand cliffs about 250 feet high, which are prominent and show white from the southward. The entire country in the vicinity of the point is from 300 to 400 feet high and thickly wooded.

Remarks.-At the close of the dry season the forest fires, which everywhere prevail, produce so much smoke as to obscure all the higher land, and also that near the coast, except when close to, so that one not familiar with the country would greatly overestimate his distance, and owing to the peculiar lay of the land in regard to the "rising sun" a shadow is cast beyond the beach line of breakers, making the beach appear much farther 
than it really is. Navigators passing or approaching this portion of the coast should bear this in mind.

The white cliffs or bluffs, which are the only ones along this coast, lie back of Tartar shoal, and are the principal marks for it.

Passing Maldonado at a distance of 7 or 8 miles from the land, no point, bight, or hook can possibly be distingui-hed. The whole coast appears as one beach or line; but close in (inside or near Tartar shoal) the two points of Maldonado can easily be made out. A ship, for safety, shonld never be that close to the shore.

When well outside of the shoals, say 6 or 8 miles, a scicond range of hills will show above the shore range or beach bluff's. If, however, the back range is not visible (the weather being clear) the ship is too near the shoals for safety. As it is impossible, too, during the "smoky time," to distinguish objects on the land at a distance of 5 miles, navigators should always shape their course so as to pass Maldonado point at a distance of not less than 8 miles.

The current sets E. by S. to SSE. It varies from $\frac{1}{2}$ to 2 knots per hour, and in strongest on the ebb tide E. by S. Close in to the point the flood sets to the northward and westward.

About 6 miles SW. of the point very heary "tide rips" were observed; the water would curl up to the point of breaking. The U. S. S. Tuscarora sounded through, in, and around it, but the least water ever found was 18 fathoms.

Anchorage may be had to the northward and westward of Tartar shoal in 6 or 8 fathoms; sandy bottom anywhere along the sand beach. The best is nearer the wreck and punta Escondido than farther up-that is, if you intend to land with your boats.

Coast.-From "El Recodo" or the bluffs of Maldonado there is a white sand beach for 49 miles to the mouth or bar of the rio Verde. This long sand beach, which is steep-to, and surmounted by palms and low bushes, is broken only twice by low rocky bluffs.

Just east and back of the Maldonarlo bluffs there is an extensive low plain, well cultivated for this part of Mexico, with a few villages on it and a large lagoon near the beach. $\quad$ N. $42^{\circ}$ E. (N. $34^{\circ}$ E. mag.) of Maldonado, and 24 miles from the coast, there is quite a remarkable fort or castle-like mountain, with a cone-shaped turret at each end of the ridge; the cones are 3,400 (left) and $3, \$ 00$ (right) feet high and the ridge about 6 miles long. They make an excellent mark for Tartar shoals if coming from the eastward in clear weather. During the months of April, May, June, and the first part of July, the atmosphere is so smoky and hazy at times that it is inpossible to see and distinguish objects 2 miles from the beach.

Anchorage may be had off the beach to the eastward of the bluff in 7 to 10 fathoms; the bottom is of coral and rock; and uneven. 
Seven miles from El Recorlo is a village and 9 miles from it another, near a small bluff and an outlet to a lagroon. Five miles to the eastward of these bluffs are four or five rocky bluff's of whitish color 50 to 75 feet high, with two or three small rocks to the southward and westwarr $\frac{3}{5}$ mile off the beach. At these bluffs, to the westward, is the mouth of the rio' Tecogame, and the Alotengo lagoon. The land back of the beach is lieavily wooded, and in a series of foothills or ranges finally attarns an altitude of upwards of 8,000 feet. These fonthills or ranges commence near the beach and run off in a north and easterly direction and in going up or down the coast in shore, in a west or east direction, the sea end of these ranges have the appearance of points and islands when first seen and before they are well above the horizon.

Just to the westward of the rio Verde the land rises rapidly to a height of 1,000 or 1,200 feet, and just off this beach in the bight to the westwarl of the river the water is the shoalest and most uneven.

Five miles N. $60^{\circ} \mathrm{W}$. (N. $68^{\circ} \mathrm{W}$. mag.) of the rio Verde are two or three rock bluffs, and $1 \frac{1}{2}$ miles $\mathrm{N} .60^{\circ} \mathrm{W}$. (N. $68^{\circ} \mathrm{W}$. mag.) of these bluffs there is a reef of rocks $\frac{1}{5}$ mile off shore. These rocks are two or three in number, from 10 to 15 feet high, and can be seen only when close in ; the water is deep and free just outside of them.

Coming from eastward or westward the land at the rio Verde appears as a low, sandy point covered with trees, one or 2 miles long, with heavy breakers off it.

Rio Verde, the largest river on this part of the coast, is about 50 miles to the eastward of Tartar shoals. It runs to and beyond, Oaxaca, and like the Sacatula, after draining a large extent of country, deposits an immense anount of débris at its mouth. It is supposed that the low land at its mouth is gradually extending or growing out into the sea, and that the river causes the shoal water to the westward, as well as the holes and deep pits outside. During and after the rains the water is cliscolored for a long distanc: off shore. Its mouth is closed by a bar, which has very little water on it, and on which at a distance of $\frac{3}{4}$ mile from the beach the sea breaks heavily. The breakers extend in a horseshoe shape from beach to beach, with deep water close to the outer curl. The natives give information, and their statement is confirmed by the Jefe Politico of Tutupec, that there are several rocks directly in the line of breakers. It is impossible to enter the river with boat or canoe, and the natives even never attempt it.

Six miles eastward from the bar of the river is the punta Galera.

Playa San Juan is the beack between the rio Verde and punta Galera.

Punta Galera or the Little Morro is a bold, barrell, and isolatel rocky bluff or headland, of a grayish color, with several detacherl rocks otf its eastern end, and connected with the mainland by a low, narrow strip of land. When first seen, in approaching it from the westward or eastward, 
it appears as an island well out from the coast line. Coming from the westward inshore, Galera appears as an island, with morro Hermoso to the northward of it and over the Verde point.

At $\frac{3}{10}$ mile SE. of punta Galera there is a sunken reef, with as little as 6 feet of water on it at low water. With a heavy swell the sea occasionally breaks on this reef. At $\frac{3}{5}$ mile eastward of punta Galera, and one mile from the sand beach, there is a low reef of rocks from 10 to 15 feet above water. This reef, about 300 feet Jong, runs in an east and west direction; the sea breaks heavily on the reef.

There is deep water all around the rochs and a passage between them and Galera, but owing to the sunken hidden reef to the southward and westward of them, the passage can not be considered a safe one.

Chacahua lagoon. - To the north ward of the Galera is the outlet to the Chacahua lagoon, with a sand bar across it, and a depth of 4 feet during the rainy season, but at other times it is dry all the way across, and the surf breaks heavily upon it. When the bar is open a boat can enter the lagoon "by watching for a smooth time" with no greater inconvenience than filling.

This lagoon extends from the Galera to the base of the morro Hermoso and some distance inland; its waters are fresh, but highly impregnated" with sulphur, and even were its waters sweet a supply could not be obtained owing to the difficulty in crossing the bar. The lagoon has a depth of from 12 to 15 feet during the rainy season, but this is reduced about 4 feet during the dry season. Just back of the Galera, nativesulphur in small particles crop out on the surface of the hill, and metal implements change color in a few minutes when immersed in the waters of the lagoon.

Tututepec is about 10 miles $\mathrm{N}$. by E. from the Galera. It is an Indian village of 2,000 or 3,000 inhabitants, governed by a Jefe Politico. 'This village is situated on a spur of the foot-hills about 900 feet above the sea, and can be well seen from the offing when the sun shines upon it; the cluurch shows as a white spot on the hillside.

Between Tututepec and the coast there is an extensive plain plentifully watered by clear and running streams and well arlapted to the growing of sugar cane and cotton.

To the northward of Galera and Tututepec the hills are brown and barren, having a spotted appearance from the offing, whilst elsewhere they are densely wooded.

Supplies.-Beef, fowls, eggs, fruit, etc., can be obtained by sending for them to the village.

Chacahua bay lies between Galera on the west and morro Hermoso on the east. It is formed by the sand beach breaking away to the northward for about a mile and then trending in a gradual curve to the eastward until 
it joins the morro bluffs. It is about 6 miles wide in an east and west direction and only about a mile deep in the western part of the bay.

Anchorage. - There is a good anchorage anywhere in the bay, but the best is between the reef of rocks (above the water) and the sand beach to the northward. Back of the bay the beach rises to a ridge which is covered with a dense undergrowth and stunted trees.

Morro Hermoso, a rounded bluff or headland about 8:30 feet high, looks like an island when coming from the eastward or westward. On its south face it is quite steep, bare, of a redish color, and without any vegetation, but on its inshore side and to the middle of the top it is covered with heavy undergrowth and thick timber. The line letween the wooded and barren part is well marked. The eastern end of the morro is only abont 300 feet high, and very abrupt on the sea face. The SE. point of the morro is called Encomiedo point.

A ressel can pass within a mile, as all known rocks and dangers show themselves above the water and are close to the rocky shore.

Rio Grande.-At $3 \frac{1}{2}$ miles from Encomiedo is the mouth of the rio Grande, which, like all other rivers here, is closed with a sand bar, open only during the rainy season. The water is shoal off the mouth of the river and between it and morro Hermoso.

Coast.-At $6 \frac{1}{2}$ miles eastward of Encomiedo point is a low, flat rocky bluff only about 30 feet high, breaking the sand beach, the first break in the beach east of the morro. SE. of this bluff, $\frac{1}{2}$ mile from the beach, there is a sunken rock with only 9 feet of water on it. Occasionally the sea breaks on this rock, but this can not be depended upon.

Piedra Blanca or Alcatraz.-At 10 miles, eastward of Encomiedo point there is a sharp black rocky bluff about 90 feet high, and a mile east of this is a small rocky islet called the Piedra Blanca. It is about $\frac{1}{10}$ mile long in an east and west direction and of whitish color. Off it to the eastward there are a couple of detached rocks showing above water. The islet is about $\frac{1}{4}$ mile off the beach, with from 2 to 6 fathoms inside of it, but the passage is not safe, as there is a reef extending off the NW. end in the direction of the sharp black bluff to the westward. The water is deep close to, outside of Piedra Blanca. About 6 miles east of Piedra Blanca is the mouth of the Manialtepec river, to the east of which are a few huts on the beach, and a small village a mile or so back. From Piedra Blanca the coast trends in a gradual curve to the eastward for 15 miles to the bluffs on the west side of Escondido bay.

Escondido blufis are perpendicular and rocky and from 50 to 100 feet high, flat on top, the seaward face of a grayish color and their tops covered with low bushes and trees. These bluffs are the only ones of any size from morro Hermoso to those westward and back of White rock, near port Angeles. The extreme western bluff is a low flat point of a decided red 
color. There is a bright yellow spot about midway in the Escondirlo bluffis, which can be seen a long way to the westward.

Escondido bay lies between the bluff's on the west and Escondido point on the east, and is open to south and westerly winds. It is an excellent anchorage with good holding ground. Bring the rocks Piedra de la Marina, in the northeastern part of the bay, to bear about N. $20^{\circ}$ E. (N. $12^{\circ}$ E. mag.) and anchor in 11 or 13 fathoms of water on this bearing.

The east part of the bay is formed of rocky bluff's and point, with two or three detached rocks lying off and close to the point. To the south ward and westward the water is shoal.

Landing is good at the head of the bay.

Supplies.-Beef, fowl, eggs, fruit, etc., can be obtained here, but no fresh water.

Cerro de la Ocote, 2,161 feet high and 4 miles NNE. of the bay, with the high bluff, is the best mark for finding the bay. The lead will guide you in and to the anchorage.

San Pedro de Mistepec is about 9 miles north of Escondlido bay, and like Tututepec and other small inland towns, is governed by a Jefe Politico.

Road to Oaxaca.-There is an excellent road from Escondido to the city of Oaxaca, and, judging from information received from the natives, the road is better and shorter than that from port Angeles to the same place; these two roads join some leagues from the coast.

Punta Sicatela.-From Escondido point the coast trends southeastward for 2 miles to a low sandy point, called punta Sicatela, covered with mangrove bushes. Off this point the water is shoal, and breakers extend some distance from the beach.

Sicatela river, just west of punta Sicatela, is a large and important stream for Mexico, but, like nearly all these rivers, its mouth is closed with a sand bar, over which a boat can not pass.

At 9 miles eastivard of the river the sand beach is again broken by low rocks and flat bluffs extending into the sea.

Point of Rocks is a low point with several small detached rocks. off it; the water is shoal, the bottom rocky, and heavy breakers extend some distance out from the shore. For upwards of 5 miles along here there are several rocks and bluffs on the beach, with very foul bottom off them.

Coast.-Eastward $15 \frac{1}{2}$ miles from the point there is a large bold rocky bluff projecting a little from the general line of the coast. It is 255 feet high, covered with brush and dense foliage except on the sea face, where it is bare brown and yellowish rocks. . Uff its base are a couple of detached rocks 20 to 50 feet high.

Counting the sand beaches as commencing at morro Hermoso, this bluff is at the extreme east end of the beach as it is also the first commencement of the rocky bluffs to the wẹstward of port Angeles. 
A mile southeastward of this bluff, there is a low rocky point projecting $\frac{1}{2}$ mile in a SSE. direction from the coast, off which there are several detached rocks. East of the end of the beach, $\frac{1}{2}$ mile, there is a sm oth rounding hill, brown in appearance. Coming from the westward it projects and shows as a bare point.

From the end of the sand beach to port Angeles, a distance of $5 \frac{1}{4}$ miles, the coast is a continuous series of rocky bluffs, rising abruptly from the beach to a height of from 100 to 500 feet. Several small rocks lie off these bluffs and shore line, but they are close in, with deep water outside.

White rock lies $2 \frac{1}{4}$ miles westward of port Angeles. It is a round, rocky islet of a whitish color, and 106 feet high, nearly $\frac{1}{2}$ mile in circumference, and abont $\frac{1}{3}$ mile from the beach. The outside or south edge off this rock is the extreme south point of the Mexican coast, west of the gulf of Tehuantepec.

Black rock.-One-quarter of a mile west of the White rock is a small detached rock, black in color. It is 40 feet high, and not more than 50 feet across.

Caution.-The coast recedes a little back of these rocks forming a shallow bay. The bottom is very foul, in fact full of sunken rocks, and no vessel should enter it, nor should she go within a mile of the rocky bluffs to the westward of White rock. A ship can go within 200 yards of White rock or the bluffs to the eastward or the rvestward of port Angeles, as there is deep water and all dingers show themselves abrve water.

Port Angeles, or Pachutla, as it is called by the natives, is the port of entry of Oaxaca. The entrance to the bay is $2 \frac{1}{4}$ miles from White rock. The best way for strangers to find the entrance, is to get close to White rock and then steam close inshore to the eastsvard; the distance, $2 \frac{1}{4}$ miles, is no sure guide, as the current may be strong either with or against you. The west side of the bay is marked by a sharp, rocky point 150 feet high, in which there are two or three caves or holes through which the sea washes.

The head of the bay is marked by a white sand beach about 500 feet long. This is the first sand beach seen after reaching the bluffs to the east of White rock. East of the entrance there is' a bold, round abrupt bluff, 300 feet high, covered with trees, with a low detached rock off it.

A very good road runs from port Angeles to the city of Oaxaca. All the bluffs in the vicinity of port Angeles are covered with a dense undergrowth and trees; their faces are bare, abrupt, and gray, while their bases, where the sea washes against them, are dark or almost black in appearance.

Anchorage.-The bay is very small and of not much depth, but gives good shelter and an excellent anchorage for schnoners and small craft during the dry season. Large vessels can anchor inside of the line from the outer SW. rock to the SE. bluff in 15 fathoms of (water; bottom, gravel and 
sand, and, with 45 fathoms of chain, will swing clear of the rocks on either side. At times a very heavy swell sets into the bay. To the eastward of the sand beach at the head of the bay, and out of sight from the entrance, are three or four buildings used as storehouses.

The coastwise steamers of the Pacific Mail Steamship Company call here - twice a month en route to and from Acapulco.

Supplies.-Neither water nor supplies can be obtained; there is a small spring of excellent water near the head of the bay, but the quantity of water to be gotten from it is insignificant; there is good shooting, and small gañe is very abundant.

Oil wells.-About $1 \frac{1}{4}$ miles east of port Angeles, between two large bluffs, is another sand beach about the size of the one at port Angeles, but not so far back. Up the hillside back of this beach are two buildings of a reddish color. These and the sand beach are good marks, when close in, for the bay of port Angeles when coming from the eastward. Near these buildings are the "oil wells," which are of very little value and are not worked at present.

Coast.-From Angeles the coast breaks away to the northward and eastward for nearly 4 miles and then trends in a general easterly direction for 15 miles to the entrance to Sacrificios bay. There are several rocky biuffs in this stretch of coast with strips of sand beach between. Ten and 13 miles from Angeles are two different reefs of detached rocks, above and below water, from 10 to 20 feet high. They extend $\frac{1}{5}$ mile off the beach, but as they show themselves and as the water is deep outside of them, they can be approached, if necessary, to within a mile.

The land back of the bluffs between port Angeles and Sacrificios is heavily wooded, but low and flat when compared with that to the eastward or westward.

The deepest water on any part of the coast from Mangrove point to Ventosa is found to the southward off port Angeles and Sacrificios.

Currents.-Along the coast from Tartar shoals to Ventosa the currents are exceedingly irregular, both as to direction and force as well as to duration, sometimes setting to the eastward with a velocity of from $\frac{1}{2}$ to $2 \frac{3}{10}$ knots per hour; within twelve hours they stop and run as strong in the opposite direction.

Commander J. W. Philip, U. S. N., says: "Once, while anchored $\frac{1}{2}$ mile off the beach to the westward of the rio Verde, the current set $\mathrm{N}$. by $\mathrm{E}$. directly on the beach, at the rate of $\frac{7}{10}$ mile an hour, and while this lasted only three hour., it was long enough to affect a ship close in to the shore."

Sacrificios bay is a small harbor adapted only to small vessels. The soundings inside are regular. The whole shore of the bay has many outlying and sunken rocks, on which the sea breaks heavily. 
Sacrificios island.-There is a passage between this island and the mainland with 4 fathoms, but it is not advisable to use it.

Supplies.-No water and but few supplies can be obtained at Sacrificios, which, though formerly a port of entry for the city of Oaxaca, is now abandoned.

Rock. - A sunken rock lies near the fairway entrance to the inner anchorage and has but 11 feet of water over it at low water. There are 7 fathoms of water close to this rock on all sides.

Directions.-To enter the harbor, bring the west point of Sacrificios island to bear N. $19^{\circ} \mathrm{E}$. (N. $11^{\circ}$ E. mag.) and then in on this course until the south extreme of western entrance point bears $\mathrm{S} .86^{\circ} \mathrm{W}$. (S. $78^{\circ} \mathrm{W}$. mag.) from this point N. $2^{\circ}$ E. (N. $6^{\circ}$ W. mag.) leads in, in depths of $7 \frac{1}{2}$ and $5 \frac{1}{2}$ fathoms.

Cacaluta island.-From Sacrificios the coast trends to the northward and eastward $4 \frac{1}{2}$ miles to Cacaluta island and is a succession of bold bluffs about 100 feet high, with detached rocks off but close to each bluff. The tops of the bluffs are covered with dense undergrowth and bushes. The island is about $\frac{3}{10}$ mile across and 220 feet high; it is $\frac{1}{5}$ mile off the main. There is a white sand beach back of it and on each side of the island.

From the island the coast trends to the northward and eastward about $2 \frac{1}{4}$ miles to the Bufedero, the entrance to Guatulco river.

Anchorage.-To the eastward of Cacaluta island there is an anchorage in 7 fathoms of water and a good boat landing. When in the offing, abreast of Cacaluta, that island and the first bluff east of it appear as two bluff headlands, and hoth might easily be taken for islands. Back of the island the Tayuta river empties into the sea, and here fresh water may be had with little trouble.

Bufedero.-There is a cave called the "Bufedero," in one of the rocks, level with the water and close inshore, and every. swell that comes in throws a quantity of water into it, and as the cave has a small aperture in the upper part of it, the water flies up, resembling the spout of a large whale. During the night time or in foggy weather, when it is blowing off shore or in a calın, the sound, like the blowing of a large whale, can be heard at some distance.

Guatulco harbor.--The Bufedero is the best and only well-defined mark for making the harbors of Guatulco and Santa Cruz. In fact, those harbors are so difficult to distinguish that vessels have been upwards of a fortnight finding them. But with the Bufedero to the westward and Piedra Blanca to the eastward and cerro de Zadan bearing due north, there should be no difficulty in finding Guatulco.

The bays of Guatulco and Santa Cruz are together, being separated only by a small peninsula 150 feet high, jutting out from the mainland $\frac{4}{10}$ mile. 
The inner harbor of Guatulco is the best and only one for small vessels from Acapulco to Ventosa. Here you can ride at anchor, landlocked whereas anywhere else the anchorage is open to the SW. winds, which often blow here. There is good clear ground anywhere and gradual soundings from 20 fathoms to 5 fathoms and 3 fathoms very near the beach. The bay is bounded by a smooth shore very good to land upon, and at the bottom of the bay there is a small fresh-water brook running into the sea during the rainy season.

Santa Cruz bay, which joins Guatulco bay, is much larger and more open, and an anchorage can be had in any portion of it in 5 to 10 fathoms, with shelter from all winds except those from the south ward and eastward. As both bays are open, no sailing directions are needed except the common sense of keeping off the visible rocks and anchoring so as to have room to swing.

No supplies can be had in either of these two bays except fresh water and fresh beef in small quantities.

When about 5 miles off shore from the Bufedero the extreme western point of land has a rocky, broken appearance, and is not so high as the land adjoining. When 6 miles out another cape farther westward can be seen. Its extreme point is rather low, but rises gradually inland to an elevation of 1,200 feet. 'This "low point" as it appears is the land of port Angeles.

Piedra Blanca.-To the southward and eastward ${ }_{1}^{4} \overline{0}$ mile in the continuation of the peninsula which separates the two bays is a reef. $1^{2}$ mile long, lying in an east and west direction. The westernmost rock, which is 90 feet high and about $\frac{1}{4}$ mile in circumference, is called Piedra Blanca (of Guatulco), and is.composed of 8 or 10 separate rocks, the smallest of which is barely above water. There is a passage between this reef and the peninsula, but it is not safe, as another reef extends some distance from the peninsula in the direction of Piedra Blanca. When in the offing perhaps the best mark for the harbor of Guatulco is the cerro de Zadan, a bell-

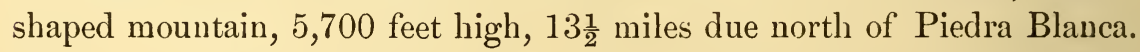
This is of reddish-brown color, owing to the absence of any brush or undergrowth (this "brown" may be green during the rainy season), and at its northern side a ridge connects it with the higher range of the Cordilleras.

Cerro de Leon, 10,300 feet high, is 10 miles N. $50^{\circ} \mathrm{W}$.(N. $57^{\circ} \mathrm{W}$. mag.) of "Zadan," and is the highest peak along this part of the coast. The land back is covered with stunted trees and brush wood, but over the foothills a few miles from the cuast the land is well cultivated.

Tangola Tangola bay, which is next to, but separated from Santa Cruz bay by a peninsula $\frac{5}{8}$ mile wide, has several small rocky islets in it that can be approached close to, and there is no danger in entering the bay to find anchorage, where there is good holding ground in from 5 to 10 
fathoms, bottom of sand and shell. Off the western entrance there is a reef of rocks, but the water is deep close to the outer rock, which is awash. There is usually a very heavy swell setting in from the southward.

Supplies.-Fresh water can be had with little trouble, as there is an excellent spring and stream at the head of the bay, but no provisions can be obtained. There is said to be good shooting in the vicinity, and pearl oysters and abalones are abundant.

Tangola Tangola island is separated from the mainland by a channel $\frac{1}{5}$ mile wide, with 3 fathoms of water in it. This passage, even though keeping near the mainland, is considered unsafe. The island is remarkable in appearance, and easily recognized. It is about $\frac{4}{10}$ mile long $\mathrm{NE}$. and SW., $\frac{3}{10}$ mile wide, about 200 feet high, and on top covered with a heavy undergrowth and bushes. From the westward the island makes as part of the mainland; the outer part is quite bluff, or rather a cliff of brownish stone.

Capulita river empties into the sea, 3 miles NE. of Tangola Tangola. It is a small stream with a bar across its mouth, which is impassable.

Sunken rock.-.-Off the second bluff, to the eastward of Tangola Tangola island, there is a sunken rock. It lies SE. of the bluff and within 100 yards of the beach.

Coast.-From Tangola Tangola the coast trends in a NE. direction for 20 miles to the morro de Ayuca, the southern part of an open bay lying in latitude $15^{\circ} 52^{\prime} 17^{\prime \prime} \mathrm{N}$. and longitude $95^{\circ} 46^{\prime} 42^{\prime \prime} \mathrm{W}$.

There are some twenty-odd headlands in this stretch from 100 to 200 feet high, which do not project much beyond the general line of the coast. Most of them have a steep cliff facing the sea, with fine sandy beaches between them. The land back rises in irregular-shaped hills towards the Cordilleras, which are three or four ranges or foothills, then the high (10,000 feet) back range.

Anchorage may be had abreast the beaches in from 8 to 10 fathoms water, sandy bottom, about one mile off the beach.

Morro Ayuca is a bold cliffy point, 270 feet high, surrounded by a reef with deep water close to. The reef extends around the morro to the northward, losing itself in the sand beach of the bay.

Back of and near the morro is a large lagoon, into which empties the small river of Ayuca, the stream that runs by Haumilulu. During the rainy season the lagoon breaks through the beach just to the westward of the morro.

Ayuca is an open bay and vessels can anchor anywhere in it, being guided only by the draft of the vessel and the locality of Ranger rock. The bay is open to all winds from the east and the south to SW., yet it is a safe anchorage at all seasons. 
The best anchorage, however, is in the western part of the bay, in 7 fathoms of water.

Estrete island, $11 \frac{1}{2}$ miles from Ayuca, is a barren, rocky, white islet, composed of two rocks of about equal size and two or three outlying reefs. There is a passage between the island and the mainland, with deep water all around and close to the rocks.

Coast.-Between morro Ayuca and punta Chipequa, a distance of 25 miles, are several bluff headlands with fine sand beaches between them. These bluffs, which are gray and almost perpendicular to the water's edge, do not project far out from the general coast line and afford no shelter.

Back of the beach the hills are barren and brown, but during the rainy season their appearance is more pleasing. Twenty miles from the Ayuca and 8 miles from Estrete island there is a remarkable dome-shaped bluff, covered with a dense undergrowth of stunted trees and bushes. At the base of this bluff, close to the beach, are two detached rocks, conical shaped, and from 20 to 30 feet high.

Rock awash.-From $\frac{1}{2}$ to $\frac{1}{4}$ mile from this dome bluff there is a rock awash. At high water it can not be seen, as the sea seldom breaks on it, but at low tide the sea breaks at each swell and the rock is visible. Seven to 12 fathoms are found close up to the rock.

The currents here are very irregular and at times very strong.

Bamba bay.-At the dome bluff just mentioned the shore breaks away to the northward to punta Chipequa and forms the bay of Bamba. This should not be entred unless actually necessary, as there are two sunken rocks in the western part, $\frac{1}{2}$ to $\frac{3}{4}$ mile from the sand beach.

Punta Chipequa is a very remarkable headland and one immense and growing sand downs.

It projects nearly a mile from the line of the coast and forms a kind of double headland. At sea, from the westward, it shows as a bold, dark cliff, surmounted by a belt of sand over its top or back, and is an excellent landmark. Its outer end is rounding and brown, then the rest is a remarkable sand down, both sides being covered with sand from the top to the beach; the whole being quite bare of vegetation, a few stunted bushes being on the eastern slope, cropping through the sand.

This is the first sand down seen from the westward, though there are two or three smaller ones between it and Ventosa.

Just back of Chipequa is a very remarkable knife-like rirlge from 1,000 to 1,50 feet high, sloping gradually to the westward but almost perpendicular to the eastward, one-third of the way down from the top. The backbone of this ridge, $\frac{1}{2}$ mile long in a $\mathrm{NW}$. by W. and SE. by E. direction, terminates in a reef off punta Chipequa. This reef lies northeastward from the point and is $\frac{3}{4}$ mile from the nearest beach. It consists of four or five detached rocks, from 10 to 15 feet high and 125 feet in extent. Between 
the rocks and the shore there are only about 2 fathoms of water at low tide, while outside and close to the rocks the water is deep. It may be mentioned here that detached rocks and rocky reefs extend off all the points from Sacrificios to Ventosa, and it is not prulent to go within $\frac{1}{2}$ mile of any of them.

Punta Guela-gichi.-At Chipequa the coast breaks away to the NNW. for nearly 2 miles, then curves gradually to the eastward, terminating in a bold bluff 535 feet high, nearly $\frac{1}{4}$ mile wide, and covered with stunted pine trees.

Chipequa bay, between the two last-mentioned points, is about 5 miles wide and from one to 2 deep. There are clean even soundings on a sandy bottom, from 2 fathoms close in to the beach to twenty-odd at the outer limits of the bay. The beach is clean, hard, white sand, back of which is a level plane, heavily timbered, extending to the foothills. Near the beach is a lagoon and well of fresh water.

Commander J. W. Philip, U. S. N., says of this bay: "Although Chipequa bay is open to all winds from the NE. to the south, I consider it the best anchorage in all seasons from Acapulco to La Union. It is far more commodious and better protected; has a better boat landing, less surf, and is in every way superior to either Ventosa or Salinas Cruz. At the full and change of the moon a heavy sivell always sets in and increases the surf on the beach, but during a number of visits no boat ever swamped or capsized, although landed at all hours of the day and many times as late as midnight."

Anchorage.- There is good holding ground in all parts of the bay, but the best anchorage is in the western part, between the reef of rocks and the sand beach to the northward. No supplies of any kind can be obtained here, but there is excellent shooting.

Coast.--There are four bays or anchorages between Chipequa and Ventosa point, viz, Chipequa, Conejo, Salina Marques, and Salina Cruz. The whole of this coast can be approachèd within a mile in safety, while off each bluff are detached rocks showing above water, and between the bluffs are stretches of sand beach on which the surf breaks heavily. On Conejo and morro de Salina Marques are sand downs which are not so extensive as that on Chipequa point.

Conejo bay is formed by a small indentation of the coast line between Conejo bluff and morro de Salina Marques. It is about 2 miles wide and a mile deep and is open to easterly and southerly winds. The soundings are even all over the bay and the holding good, but on account of the heavy surf rolling in on the steep beach there is no boat landing.

Back of the bay, $\frac{1}{4}$ mile from the beach, is a solitary conical peak 300 feet high, called Hermosa cone. 
Salina Marques bay lies between morro de Salina Marques and morro de Salinas. It is a little larger than Concjo, lies in the same greneral dirèction, and while the soundings: are regular on a hard sand bottom, there is no boat landing. Back of the sand beach there is a large lagoon which discharges into the sea during the rainy season. The two bays just mentioned are of but little or no use, owing to the close proximity of the bays of Chipequa and Salina Cru\%.

Morro de Salinas is a round rocky projuction, just outside of which are several clusters of rocks above and under water to an extent of 250 yards. The water is deep just outside of them. The morro is ' 241 feet high, with an almost perpendicular cliff to the eastward.

Sunken rock.-There is a sunken rock to the southward and westward of the morro and about 200 or 300 yards off shore. It is on a line with morro de Salina Marques and the outer rock.

Salina Cruz bay, formed by a slight indentation of the coast between the morro de Salinas and Ventosa point, is exposed to all winds except the "Norther," which here blows with great fury. In anchoring, run in as close to the beach as possible and let go. The bottom is hard sand. The bay is surrounded by hills on its northern and western sides, ranging in height from 200 to 2,000 feet high. Five miles from the anchorage is a remarkable "whale-back" mountain, called "Tecuani," 2,214 feet high.

Shadani, $3 \frac{1}{2}$ miles from the anchorage and $1 \frac{3}{4}$ almost due east from flat-top Tecuani, is a remarkable square flat rock, 60 feet high and 150 feet square, on a peak 1,070 feet high. This "house rock," called the Shadani, resembles a house when seen from a distance of 2 or 3 miles at sea. The flat-top mountain and this rock are the two best landmarks for Salina Cruz when approaching from the sea, as they can be seen and recognized farther than anything else.

Salina Cruz is the port of entry of Tehuantepec, the customhouse having been brought here in 1862 from Ventosa owing to the worthlessness of that bay. The village, which "consists of about a dozen huts and sheds, is situated on the western side of the bay, near the beach; there are the ruins of a large building on the elevated ground some 300 or 400 yards back of the village. It is only of importance as being the southern terminus of the railroad to Tehuantepec, a distance of 10 miles, and its being the port on the Pacific ocean for the city of Tehuantepec. The Pacific Mail Steamship Company's coast steamers call here on their way to and from Acapulco to land and take freight and the mails. Communication with the shore is had by means of surf lighters, especially built for the purpose, and which pass through the surf on a rope stretched from the shore to a buoy moored well outside of the breakers. The telegraphic cable lands here. 
Boat landing.-There is a good boat landing here; watch your chance and beach the boat through the surf seems to be the only way of communicating with the shore.

Supplies.-No water and very few provisions or supplies of any kind can be obtained.

Tehuantepec city, lies almost due north 9 miles from the Salina Cruz. There is a good wagon road from the port to the city ; the distance being 15 miles. The city is situated on the Tehuantepec river and is in telegraphic communication with the world.

At Salina Cruz and Tehuantepec the United States is represented by a consular agent.

Ventosa point, $2 \frac{1}{2}$ miles eastward of morro de Salinas, is a bold rocky headland jutting out from the mainland. Off the point are many outlying rocks from 50 to 150 feet high with deep water close to. The point can not be mistaken, as it is the last of the high land, on the western part of the gulf of Tehuantepec.

Ventosa bay lies to the northward and eastward of the point; it is about 2 miles wide, and but little over $\frac{1}{2}$ mile deep. The soundings in the western part of this bay are irregular, and on account of the great amount of sediment brought down by the Tehuantepec river during the rainy season, this part of the bay is fast filling up. Owing to this fact and the great difficulty in making a landing in the best of weather, together with its known inferiority to Salina Cruz, the customhouse, etc., was transferred to the latter place.

Tehuantepec river empties into the bay about a mile northward of the point. There is a bar across its mouth, whish, at low water, in the dry season, is out of water; canoes cross at high water, but heavy breakers extend a mile outside the bar, and the breakers increase or expand their outer limit from the beach, in proportion as this part of the bay fills with the deposit from the river.

Currents, tides.-Commander J. W. Philip makes the following observations on the currents and tides between Mangrove point and Maldonado: "** Along this part of the coast the current is supposed to set to the SE. and east during the winter months, and to the N IV. and west during the summer when SE. winds prevail, varying in force with the strength of the wind. The greatest current, I think, is found off the head of Acapulco, setting about ESE. from $\frac{1}{2}$ to $2 \frac{3}{10}$ miles per hour. This current is influenced by the wind and is more rapid on the ebb tide.

The tides are regular; the ebb setting to the southward and eastward and the flood to the northward and westward inshore. The rise and fall is about 7 feet at Maldonado and decreases gradually to the westward, until at Mangrove point it is only about one foot. 
At and near the full and change of the moon there is always a heavy swell setting in on the beach from the southward and westward, decreasing as the moon quarters."

Capt. W. H. Parker states as follows on the winds and currents :

Winds. - "Along the coast of Mexico northerly winds prevail in winter, and SE. and SW. in summer. The land and sea breezes are regular when close inshore; northerly at night and SIV. in the afternoon."

Currents.- "Between Teq!epa point and Acapulco: In July, eastward one knot; in June, westward $\frac{7}{10}$ knot; in $\Lambda$ pril, eastward $\frac{1}{2}$ knot; in January, eastward one knot."

Between Acapulco and port Angeles: In July, eastward $\frac{1}{2}$ knot; in December, westward $\frac{1}{2}$ knot; in January, eastward $\frac{6}{10}$ knot ; in October westward $\frac{1}{2}$ knot; in January, eastward one knot."

Current along shore in Tehuantepec gulf.-The currents which are specially under the influence of the winds are particularly so in the gulf of Tehuantepec during the season of the Northers. When a Norther is is blowing the current sets strong to the northward and eastward along the shore on the west side of the gulf, and to the northward and westward inshore on the east side of the gulf; at other times the current. sets in the opposite direction, and it is accounted for in this way: the fury of the Norther blows the water out of the gulf to the southward, and as the waters lower at the head, there is a rush along each shore to the northward, to supply or fill the vacancy. When the Norther moderates or ceases to blow, the water that was "banked up" as it were flows back up the gulf, and the extra amount rushes out along each shore to the southward and eastward on the east or Guatemala shore. As this fact has been observed as far east as rio Verde, and down the east coast as far as Champerico, mail steamers and coasters should note carefully the currents in coasting the gulf from either direction.

Off Sacrificios, the current setting to the northward and eastward has been found as high as 2 miles per hour during a heavy Norther, and $\frac{6}{10}$ per hour setting to the southward and westward when the wind was from the opposite direction.

The strongest current was off the "rock awash," 3 miles west of punta Chipequa, $2 \frac{3}{10}$ miles per hour.

Cipt. Parker states along the coast from Manzanillo to Sacrificios point the current is supposed to set to the SE. and east during the winter months, and to the NW. and west in summer when SE. winds prevail. This is not, however, by any means always the case.

In the gulf of Tehuantepec, on a line between Acapulco and Montuosa islands, the current generally sets to the WNW., but running over to the coast of Guatemala the current will probably be to the SE. and east as you approach the coast. 
Northers.-A gray mist hanging over the mountains and a red sunset, the red extending toward the zenith, are sure indications of a Norther. If on entering the gulf either from the eastward or westward a northwest(riy swell is met with a Norther will surely follow. Sometimes doubleheaded clouds are seen to the northward, with clouds or mists hanging over tops of the mountains; at others it will blow a fresh gale without a cloud in the sky. The barometer does not indicate them nor does the temperature of the water. There winds commence from the NE. or NNE., veer round to the northward, and in the gulf veer to the $\mathrm{NW}$., and finally die out at west as the coast of Guatemala is approached.

Crossing the gulf of Tehuantepec.-In the foregoing directions it is supposed to keep close along the shore of Tehuantepec down the coast during the season of the Northers. This is not considered the best plan. After passing Sacrificios point steer directly across the gulf, say N. $82^{\circ} \mathrm{E}$. (N. $75^{\circ}$ E. mag.) ; then, in case of a Norther setting in, keep the ship off so as to bring the wind and sea one or two points abaft the beam and make a run for it. Should it be necessary to keep to the southward of this course, say SE., the wind will veer to the northward and westward, enabling the ship to come up gradually to the course, and as the coast of Guatemala is approached it will veer more and more to the westward until it dies out. This is much better than to haul up to the northward in order to get under the lee of the land. This applies to the down trip.

When bound up, hug the Guatemala coast and follow close around the gulf shore; the wind then is constantly hauling ahead, and although it will be frequently found that, after passing Soconusco bluff in a Norther, the wind will temporarily die out, it will be pretty sure to freshen up again, in which case the better plan is to continue to hug the coast, giving Tonala bar a wide bertl.. If it should be blowing a Norther at the time of passing Sacrificios point, then go up at least as far as Estrete island, keeping a mile or two off shore.

In the gulf of Tehuantepec north winds prevail (sometimes with great violence) from October to April. In summer SE. and southerly winds.

Of currents Capt. Parker says:

Between morro Hermoso and lat. $15^{\circ} 16^{\prime} \mathrm{N}$., long. $94^{\circ} 37^{\prime} \mathrm{W}$., in October, westward $\frac{1}{2}$ knot.

In April, between lat. $16^{\circ} 09^{\prime}$, long. $95^{\circ} 00^{\prime}$, and lat. $14^{\circ} 18^{\prime}$, long. $92^{\circ} 00^{\prime}$, westward $\frac{1}{2}$ knot.

In October, between lat. $15^{\circ} 16^{\prime}$, long. $94^{\circ} 37^{\prime}$, and lat. $13^{\circ} 35^{\prime}$, long. $91^{\circ} 30^{\prime}$, north $\frac{1}{2}$ knot.

In Octoher, between lat. $15^{\circ} 40^{\prime}$, long. $94^{\circ} 31^{\prime}$, and lat. $15^{\circ} 07^{\prime}$, loug. $95^{\circ} 38^{\prime}, \mathrm{SW}$. one knot.

In October, between lat. $15^{\circ} 07^{\prime}$, long. $95^{\circ} 38^{\prime}$, and lat. $15^{\circ} 26^{\prime}$, long. $96^{\circ} 00^{\prime}, \mathrm{xW}$. one knot.

In October, between lat. $15^{\circ} 40^{\prime}$, lorig. $94^{\circ} 31^{\prime}$, and lat. $13^{\circ} 37^{\prime}$, long. $91^{\circ} 10^{\prime}$, eastward $\frac{1}{2}$ knot. 
In January, between lat. $15^{\circ} 41^{\prime}$, long. $94^{\circ} 00^{\prime}$, and lat. $15^{\circ} 47^{\prime}$, long. $97^{\circ} 00,^{\prime}$ eastward $\frac{1}{2}$ knot.

In October, between lat. $15^{\circ} 43^{\prime}$, long. $96^{\circ} 43^{\prime}$, and lat. $15^{\circ} 00^{\prime}$, long. $93^{\circ} 12^{\prime}, \mathrm{NW}$. by W. $\frac{7}{10}$ knot.

Winds-Gulf of Tehuantepec.-The heavy blasts which blow over the isthmus of Tehuantepec derive their source from the country which they cross, and are caused by the Northers in the gulf of Mexico, which here find a vent through the opening formed between the Mexican and Guatemalian mountains. They blow with great force from north to NNE. and raise a very high, short sea, and are felt several hundred miles off the coast. During the season when they prevail (October to April) every preparation should be made to meet and carry sail through them if not heavily laden; if this cau be done they are soon crossed, and 200 or 250 miles of westing (or easting) made; otherwise, if you are obliged to heave to, 36 or 118 hours of heavy weather may be expected, exposed all the while to a very high and short sea. In the rainy season they cease, but the weather here, as along the whole coast of Mexico, is then very bad; gales and strong breezes from SE. to SIV. constantly occur, whilst squalls, accompanied by thunder and lightning, with heavy and almost incessant rain, characterize the season throughout.

These gales are at times very serere, rendering the navigation of such a coast very unpleasant, as, with one exception, there is scarcely any shelter from them to be found. During the fine season, however, nothing can be more regular or quiet than the weather on the Mexican coast; a regular sea breeze sets in about noon, beginning from SSW. to WSW. and getting more westerly as the sun goes down, decreasing with it, and gradually sinking into a calm as the night closes in. 'This is succeeded by the land wind off the shore, which is more irregular in its direction and force; but these winds and the method of making a passage to the westivard along the coast have been so well and so truly described by Dampier and Basil Hall that nothing remains but to add testimony to the correctness of the accounts they give, as far as the phenomena fell under observation.

As soon as the coast begins to trend northward again, which it does about Tejupan point, northerly winds are met, which blow down the gulf of California, and which are found a few miles off the coast pretty steady during the fine season. By taking, advantage of these, and the daily variations caused by the land and sea breezes, the passage is made from this point to San Blas and Mazatlan; but it is always a tedious beat, owing to a contrary current and frequent caìms.

NotE.-The U. S. S. Thetis encountered a severe Norther September $29,1890$.

Ventosa point to the Gulf of Fonseca-General remarks. - To the eastward of Ventosa the coast line forming the head of the gulf of Tehuan- 
tepec sweeps away in a gradual curve, forming the arc of a circle of large radius; the character changes and the shore line is a whitish gray sand beach that extends away to the eastward some hundreds of miles, unbroken by a single rock. To the southward and westward of Ventosa, to and beyond the turn of the gulf coast at port Sacrificios, the shore line is of a rocky and biuff character, with intermediate sand beaches, while the mountains are rugged and stand not far back from the shore.

The depths change from deep water, close up to the bold bluffs, to a gentle shelving bottom with only 30 fathoms of water in places, 15 miles from the shore. The mountains to the eastward somewhat resemble tablelands, and sweep away inland to a maximum distance of about 25 miles, leaving a large, low area, partly occupied by an extensive lagoon, with its numerous branches or divisions and a few scattering hills or mounds, ranging from 236 to 2,280 teet in height, the highest standing farthest to the eastward.

This area is sparsely wooded, and parts of it are under cultivation, while large numbers of cattle graze in the open.

The mountain chain forming the backbone of the continent here becomes confined to the narrow limits of the isthmus and also becomes lower, affording in one place a pass through which a survey for a proposed interoceanic ship canal is located. A telegraph line crosses the isthmus here, starting at Salina Cruz, connecting with the telegraph cables on either side that form a part of the North and South American telegraphic system.

After this low place is passed, the mountains gradually begin to rise and spread out, approach the coa-t line again, until, at Soconusco bluffs, a detached cluster of hills very near the beach form a prominent landmark. Farther to the eastward the mountain chain extends nearly parallel with the shore line, and between it and the shore there lies a low, wooded belt filled with many lagoons.

The entire coast line from Ventosa point to Acajutla is a sand beach with not a single outlying danger, while back of the beach is a lagoon which extends nearly the entire distance, and it is fed by the streams and rivers flowing down the coast.

Anchorage may be readily found in from 10 to 15 fathoms water, with sandy bottom, almost anywhere along this stretch of beach. There is 110 protection against winds from any direction, but the Northers blow off shore and vessels can readily put to. sea.

Landing.-A heavy surf is almost constantly breaking on this beach, and landing is an extremely hazardous undertaking; at times, however, the surf becomes quite quict, and a landing may be made at any point.

Winds.-Besides the variable winds, which are rather light, and the land and sea breezes of the murning and evening, two prevalent winds, the NNE. and SSW., blow during a great portion of the vear on the 
southern coast of the isthmus. The first of these is not felt to the eastward beyond the boca of Tonala, nor to the westward beyond the mountains of Chahuhe, the west bounds of the lagoon of Tongulunda. The NNE. wind, which usually begins about the 15 th of October and ceases in the first part of April, in November blows almost without interruption, and at that time reaches its maximum, while towards the middle of December it ceases during intervals of from ten to twelve days, and then begins anew to blow one or two weeks. These alternations or interruptions are reproduced at short and uncqual periods. The length of the period of discontinuance goes on gradually increasing till the wind only blows one day and finally ceases completely.

The Indians of Santa Maria del Mar, who are faniliar with the coming of the NNE. winds, say if about sundown the summits of the mountains of Guichicovi and San Miguel Chimalapa (seen from the coast) are concealed from view by quantities of slate-colored vapor it is an indication that the Northers will blow the following day and last as many days as the summit of these mountains continue to be covered with similar clonds. Vapors of a corresponding hue, seen at the same hour, on the horizon of the Pacific ocean announce that the SSW . winds will blow the day following.

The SSW. wind, which in winter succeeds the northerly, during the one or two days of its cessation, is the only general wind prevailing during the months of June, July, and August. After some gales of more or less intensity, which may be compared to the violence of the northerly wind, and not exceeding one and a half or two hours' duration, the southerly wind is definitely fixed; still, this wind is subject to more interruption than the north wind and the intervals of repose are longer. After passing over the ocean this wind reaches the "oast of the isthmus laden with vapors which at certain hours of the day resolve themselves into abundant showers. In winter and in summer, during the prevalence of the southerly and northerly winds, the current of the sea is from east to west; its greatest relocity is about $1 \frac{1}{2}$ miles an hour.

Coast.-From V'entos I point the beach trends ENE. for 23 miles to San Francisco bar or Boca Barra (mouth bar).

At $9 \frac{3}{4}$ miles from Ventosa is a high-water break or closed mouth of a lagoon and $\frac{3}{4}$ mile further on a second break, both connecting with the same lagoon.

San Mateo is midway between these breaks and about $\frac{3}{4}$ mile back from the beach. The whitewashed or painted dome of the church can be seen some distance to seaward, and forms an excellent landmark when the mountains are obscured. The cuuntry in this vicinity is low and sparsely wooded and cut up by branches of a lagoon exterding behind the beach. 
There are two other high-water breaks, distant $1: 3$ and $20 \frac{1}{2}$ miles, respectively, from Ventosa.

Santa Maria del Mar, $17 \frac{1}{2}$ miles fron Ventosa point, stands about $\frac{3}{4}$ mile back from the beach. Here also is a whitewashed cathedral tower, which forms a good mark, standing up from a group of scattered palmetto trees. This tower is an open cupola, while that at San Mateo is a dome.

San Francisco bar or Boca Barra is formed at the open mouth of an immense inland lagoon that here connects with the sea through an opening $\frac{3}{10}$ mile wide. The mouth may be readily found, as a white sand bank about 20 feet high stands about $\frac{1}{2}$ mile to the westward of the opcning, on a low spit of sand.

The growth of trees and bushes breaks off some distance on either side of the opening, so that from a few miles at sea the mouth seems broad and spacious. There are heavy breakers extending out from $\frac{1}{4}$ to $\frac{1}{2}$ mile at the middle of the mouth, and ordinarily there is not even a channel for boats. The lagoon extends to a distance of 1.3 miles back from the beach and is broad and open. It is fed by small rivers and streams, and there are several small villages on its shores. There are not over 21 feet of water in any part of the lagoon.

The village of San Franciscu stands about 3 miles NE. of the mouth of the lagoon.

Coast. - From San Francisco bar to Tonala bar, a distance of 47 miles, the shore line sweens around in a gentle curve and is an unbroken sand beach, upon which a heavy surf is almost constantly breaking, rendering landing extremely difficult. Occasionally the surf is light, and a landing can be made at any point. Between these two bars the country is low and wooderl. A lagoon extends a short distance back of the beach.

Tonala bar, in its narrowest place, is about $\frac{7}{8}$ mile wide, and on the eastern sicle a growth of trees seems to come down close to the water's edge. There is, however, a channel, and ressels of light draft can cross at certain stages of tide and sea, but the bar-is continually shifting. The breakers on the bar extend out from $\frac{1}{2}$ to $\frac{3}{4}$ mile from the beach and their outline is rounding.

Anchorage.-An anchorage can be had $\frac{1}{2}$ mile outsicle the center of the breakers in 11 fathoms of water.

Landing.- - The nearest and best buat landing is on the beach, on the eastern side of the mouth, clear of the breakers.

At 4 miles to the westward of the bar stand two or three huts on the dividing neck of land.

Coast.-From Tonala bar to Soconusco bluffs the coast line trends away with a slight curvature SE. by E. for a distance of 19 miles.

La Puerta, 8 miles to the eastward of Tonala bar, is the place of embarkation for the town of Tonala and its port of entry. It has about 20 houses 
visible on the beach, with many native huts back of it. A 600-foot pier extends into deep water.

A good mark for finding it in all weathers is Tonala bar itself, but in clear weather the high peak of Tres Picos, 7,945 feet high, is an excellent landmark. It is a place of call for the Pacific mail steamers (two steamers each way every month), and the company has a number of buoys moored outside the breakers for use in working the lighters.

The anchorage is directly off the houses, in 10 fathoms of "water. The customhouse officers are provided with a set of international signal flags, and understand their use.

Tres Picos or Soconusco volcano stands a little less than 19 miles from the nearest point of the beach. It is easily seen from Ventosa in clear weather, and from a distance appears as a cone which towers above the surrounding mountains. From Tonala bar it is seen divided into three points, the middle one being the sharpest and highest, the others being about the same șape and size.

San Marcos bar is 4 miles to the eastward of La Puerta, at the mouth of a narrow lagoon. The breakers on the bar extend out a little more than $\frac{1}{4}$ mile from the beach and are not very heavy.

Sharks are numerous and may be seen swimming in the edge of the breakers here and at all the bars along this coast.

Soconusco bluffs are 6 miles to the eastivard of San Marcos bar. They are a group of hills or mounds and have altitudes of upwards of 2,000 feet; the name bluffs's seems a misnomer.

San Bernardo hills stand 5 miles back of the beach and are wooded and green in the rainy or tropical winter, and light brown in the dry season; standing as they do so near the shore, and seeming to abut upon it, form the best landmark in all seasons for this part of the coast. It is at this point that the high mountain range approaches nearest to the cuast, and there are peaks ranging from 6,000 to 7,000 feet high standing less than 15 miles back from the shore.

Coast.-From Soconusco bluffs to Sacapulco bar the coast trends SE. by E. for 17 miles. Beyond the bluffs a belt of low wooded country lies between the shore line and the mountaine, with occasional mounds or hills standing up out of it. One of these, about 1,100 feet high and with a long ridge top, stands 5 miles back from the shore line at a point 12 miles eastward of Soconusco bluffs.

Sacapulco bar is at the opening of a narrow lagoon which seems to extend all along behind the beach to the westward and eastward. The opening is about $\frac{1}{8}$ mile wide and the breakers extend out about $\frac{1}{4}$ mile off the mouth ; there is not enough water on the bars for ships' boats.

Coast.-From Sacapulco bar to Soconusco bar the beach trends SE. for 43 miles. A lagoon follows along behind the beach for the whole distance. 
Thick woods come down to the edge of the sand and palmettos are scattered along among the other trees. At $12 \frac{1}{2}$ miles eastward of Sacapulco bar is a small village and 14 miles farther to the eastward is a second village.

Soconusco bar is similar to Sacapulco. The opening is about $\frac{1}{5}$ mile wide, with breakers extending $\frac{1}{4}$ mile off the mouth, which render an entrance by boat almost impossible. No habitations are visible here.

Tacana volcano, 14,0(30 feet high, is in sight from this bar. It is on the boundary line between Mexico and Guatemala.

San Simon bar is distant $19 \frac{1}{2}$ miles from Soconusco. The opening is about $\frac{1}{8}$ mile wide and breakers extend off $\frac{1}{8}$ mile. There are 9 fathoms water $2 \frac{1}{4}$ miles off the beach at this bar.

Puerto de San Benito is $19 \frac{1}{2}$ miles from San Simon bar, and the forest between bordering the beach is sprinkled with palmetto trees. The town consists of a group of about 30 thatched houses standing. upon and just back of the beach. The Pacitic Mail agency and the customhouse, with flagstaffs in front of them, are the largest and stand nearest the water.

Lighters afford the only means of landing. The buoy moored outside, with a surf-line fast to it, is used through the heavy surf that runs at times. The Pacific Mail steamers call here, one steamer each way every month. An iron pier is proposed. The sanitary condition of the town is poor. Climate warm and unhealthy. There is one telegraph office.

Supplies.-All kinds of provisions are very scarce. Water has to be brought from a distance of 6 or 8 miles and has a strong alkali taste.

Railroad.-A railroad is proposed to Tapachula.

Tapachula is about $15 \frac{1}{2}$ miles back from San Benito, which is its port as well as the port for the agricultural and stock-raising country adjacent, but the monthly steamers seem to do all the carrying trade.

Coast.-From San Benito the coast line trends southeastward 19 miles to the mouth of the Ocos river.

At $5 \frac{1}{2}$ miles eastward of San Benito a lagoon comes close to the beach, and is only separated from the sea by a narrow strip of land. The lagoon probably had an opening here, and the bar at its mouth is called Cuayacan bar. Three miles farther on a similar narrow place between sea and lagoon is called Suchiate bar.

Suchiate river is the boundary between Mexico and Guatemala.

At $15 \frac{1}{2}$ miles east of San Benito and $3 \frac{1}{2}$ west of Ocos river is a closed lagoon mouth called Ayutla bar.

Boundary between Mexico and Guatemala.-The boundary line commences at a point in the sea, 3 leagues from the mouth of the Suchiate river, and follows the deepest channel of that river till it intersects the vertical plane, passing through the volcano called Tacana and a point situated 25 meters from the southern pillar of the gate of Talquian. (Tal- 
quian is not located on our maps, but is very near the foot of the south slope of Tacana.)

The boundary continues in the same vertical plane till it encounters the vertical plane passing through the highest points of the mountains Buena Vista and Ixbue.

Buena Vista has been located by the Mexican scientific commission, but Ixbue is said to be at least 30 miles out of position on their best map, that is, 30 miles too far west. 


\section{CHAPTER V.}

THE COASTS OF GUATEMALA AND SAN SALVADOR.

Guatemala extends from the borders of Mexico to the rio la Paz. Population in 1888 (estimated), 1,394,000.

Guatemala or Guatemala la Nueva, the capital of the republic, is situated on a broad table land 4,855 feet in height, inland of its port, San José, with which it is connected by a railroad. Population, 65,796.

The famous volcanoes Agua, Acatenango, Fuego, and Atitlan are here seen in all their grandeur and are a distinguishing feature of this isthmus.

The principal towns are connected by telegraph.

Climate.-The climate of the republic varies greatly with the varying elevations, from the tropical heat of the coast lands and lower valleys, through the intermediate spring-like temperature of the interior plateaux and higher valleys, to the cold and sometimes almost wintry climate of the most elevated table lands and mountains. At Guatemala the climate is one of perpetual spring, the thermometer averaging $65^{\circ} \mathrm{F}$.

Seasons.-The seasons are divided into dry and wet, the latter commencing at about the middle of May and continuing until the middle or end of October; the dry season then sets in and lasts the remainder of the year.

Exports.-The exports consist of coffee, cochineal, indigo, india rubber, woods of various kinds, and hides.

Dues.-Anchorage dues, $\$ 2$. Tonnage dues, 25 cents per ton. Roll dues, 25 cents per head. Vessels of 25 tons and under and vessels touching for shelter or repair are exempt from dues.

Coast.-From the Ocos river the shore line runs in almost a straight line to Champerico in a general direction of SE. by E., distance 20 miles.

The water is shallow, but preserves a regular depth at the distance of one mile from shore of from 7 to 8 fathoms, deepening very gradually seaward.

There are no obstructions to navigation, the coast preserving a monotonous stretch of sand beach lined with trees and undergrowth; in fact, this may be said of the entire coast line from Ventosa to Acajutla; the 
water preserves uniform depths at equal distances from shore, and the shore line itself is a continuous stretch of sand beach throughout.

Ocos, just east of the river of that name, is a port of entry of Guatemala. There are twenty or more houses visible on the beach, and an iron pier 1,200 feet long, with a white shed on its outer end, extends from the center of the village out into deep water.

The place is said to be very unhealthy at all seasons.

Pacific Mail steamers call twice each month going each way.

The United States is represented by a consular agent.

Anchorage.-The best anchorage is in line with the pier in from 5 to 10 fathoms water, one to 2 miles off shore.

Light.-A fixed white light, shown only when steamers are due, is exhibited from the end of the pier at an elevation of about 30 feet above the sea and is visible from a distance of 4 to 5 miles in the direction of the length of the pier.

Champerico.-Until recently this village was only a stopping place for the Pacific Mail steamers once a month and the port for the western part of Guatemala, but now a railroad running back into the country to Retaleuleu and San Felipe has increased its importance as a port of entry and brought about a number of improvements. It has telegraphic communication. There are already many substantial buildings, and more are building. A heavy surf renders landing dangerous, but an iron pier, between 1,300 and 1,400 feet long, has been built, with steam hoisting apparatus and a cage for landing passengers, for which a fee of $\$ 1$ is charged for each passenger and baggage. Iron ladders can be found on either side of the pier for landing from boats.

The swell here is rather heavier than at any other place on the coast. At times it is difficult to land or to take on cargo unless the vessel is sprung around, head to sea.

The United States is represented by a consular agent.

Anchorage may be had in about 5 fathoms water at a distance of from 300 to 500 yards from the pier, sandy bottom with mud.

Of this anchorage Capt. Parker says :

"The tides rise and fall at about 8 feet at full and change days. At the full and change of the moon heavy rollers sometimes set in from the southward, without a breath of air, and break in 4 fathoms water. In such a case you would anchor farther out in 7 fathoms or more.

The current here in the dry season sets generally to the ESE. one knot. per hour, and more at spring tides. Sometimes, however, it will set ESE. for three or fuur days, and then set WNW. for the same time.

Do not attempt to land in your own boats at any of these embarcaderos unless it is very smooth." 
Steamers. - The Pacific Mail steamers call about six times a month going each way. There is also the Hamburg line alout once a month, and the Kosmos line about six times a year.

Coast.-From Champerico the coast continues, with the same characteristics and hydrography, for 12 miles to the small village of San Luis, at the mouth of the Samala river. Ten miles beyond, at the mouths of the Sacua and Naguala rivers, is the village of Sesecapa. A third small village, Tecojate, is at the mouths of the Madre Vieja, and Coyolate. It is a coffee port and of no great importance. The port may be recognized by a large white house on the beach used for the storage of coffee.

Seven miles from Tecojate is San Geronimo, at the mouth of the Guacalate river. It is of no commercial importance except as a coffee port. All these villages are simply embarcaderos where vessels load with coffee, dyewood, etc., bringing lighters for same from ('hamperico or San José, where they must enter and clear. The distance from San Geronimo to San José is 26 miles.

San José de Guatemala, the chief seaport of Guatemala on the Pacific coast, is increasing in importance on account of the railroad which runs to Guatemala city, $7+$ miles distant by rail. It has already about 1,000 inhabitants, is healthy, and has no endemic disease; the thermometer ranges from $90^{\circ}$ to $68^{\circ}$. Quarantine is maintained by the captain of the port, who will not allow passengers or freight to land unless the ship has a clean bill of health; there is neither hospital nor doctor. It has an open roadstead with safe anchorage in from 9 to 13 fathoms, one mile from shore.

In anchoring off San José, or in fact off any of these ports, the farther off from the beach the less the swell will be.

San José is lighted by electricity, and there is a row of twelve lights on the beach, extending from just westward of the lighthouse to eastward of the wharf, which forms a dark spot in the middle of the row. These lights can be seen during the night at a distance of several miles.

The United States is represented by a consular agent.

Winds.-From July to October SW. and westerly winds prevail, with heavy squalls and frequent rains. The winds, as at other parts of the coast of Central America, are, from November to May, generally from SE. by S. to west, from 10 a. m. to 8 or 9 p. m.; a short interval of calm then follows, which is succeeded by light winds from north to $\mathrm{NE}$.

The current is strong and changes with the tide.

- Supplies.-No coal can be obtained. Fresh provisions and water in limited quantities can be had. Water is taken on board in casks.

Pier.-There is a good iron wharf, extending 1,060 feet outside the surf, for the accommodation of lighters and small craft. Ships should have their cargoes delivered alongside, as lighterage is very high. Ballast is almost impossible to obtain and ships should bring it with them. 
Landing.-Boats land at end of iron wharf. Passengers ascend vertical iron ladders; in barl weather, they are hoisted in a cage. Landing is not bad if boats are well handled.

Telegraph.-There is telegraphic communication with the city of Guatemala, and overland to the United States and other points.

Mail.-The mail leaves every day by rail for the city of Guatemala and by the Pacific Mail steamers three times every month, both north and south, and the coast line.

Light.-A fixed white light is shown fron the cupola of the government house at an elevation of 64 feet and is visible in clear weather from a distance of 18 miles. The government house is a two-storied building erected on iron posts 450 feet west of the wharf.

The light is an electric light of 100 -candle power. It is unreliable, especially in the rainy season.

Istapa, 6 miles from San José, at the mouth of the Michatoya river, is of no importance. It lies on the northerly treud of the bight of the coast line extending from San José to Acajutla. A number of native villages are to be seen on the beach between these places. The beach is sandy and unbroken by hills or bluffs until directly at the town of Acajutla; here the coast line makes a sudden break, running directly to the southward for about 2 miles, and then trending away again to the eastward. Twenty miles west of Acajutla is the rio $\mathrm{La} \mathrm{Paz}$, the boundary line between Guatemala and San Salvador.

\section{SAN SAJ.VADOR.}

San Salvador extends from the rio La Paz about 160 miles eastward to the north side of the gulf of Fonseca. It is the most densely populated of the Central American republics, the population in 1888 (estimated) being 664,513 .

The coast presents generally a belt of low, rich, alluvial land, varying in width from 10 to 20 miles. Behind this and presenting an abrupt face seaward is a range of mountains, or, rather, a broad plateau of about 2,000 feet. Along this plateau there are not less than eleven volcanoes running in nearly a direct line from SE. to NW.

Its principal stream is the rio Lempa, which is hopelessly barred.

With the exception of La Union, a fine harbor, the ports are Acajutla and La Libertad, mere open roadsteads, and only of importance from their proximity to the cities of San Salvador and Sonsonate. La Concordia is the port of the town of San Vicente.

San Salvador, the capital, has been several times destroyed by earthquakes. Its population in 1888 numbered 16,327.

Port charges.-Entry from $\$ 5$ to $\$ 15$; tonnage, 15 cents per ton. 
Acajutla is the port of entry of Sonsonate, 12 miles in the interior, and the two places are connected by a railroad which extends to Armenia. The customhouse and huts comprising the town are on a height overlooking the shore, and are not distinctly seen from a distance, but the harbor flagsta ff $^{\circ}$ is a good guide. The harbor is an open roarlstead, partially sheltered by a reef of rocks off Remedios point.

The United States is represented by a consular agent.

Supplies.-Provisions are scarce and dear, but can be had from Sonsonate on giving notice.

Anchorage.-The anchorage is in 8 or 10 fathoms off the pier. In winter it is safer to anchor farther from shore in 12 to 15 fathoms. In making the anchorage bring the volcano Isalco to bear N. $40^{\circ} \mathrm{E} .\left(\mathrm{N} .34^{\circ}\right.$ E. mag.), which will lead in until the port is made.

Landing is difficult and vessels are obliged to load and unload by means of bungos or large lighters built like a whaleboat. Two buoys are now moored outside the iron pier which has been recently constructed.

Light.-From the customhouse a light, fixed white with red and green sectors, is shown and should be visible from 7 to 8 miles. It shows red to southward, white in the middle, and green to the northward. 'The best anchorage is in the limit of the white sector.

The light is reported of such a poor character as to be hardly distinguishable from the lights of the town.

Steamers.-The Pacific Mail steamers, the Acapulco line, and the Champerico line call at this port three times every month going north and south.

Caution.-The anchorage on south side of mole is dangerous, being rock and bad.

Remedios point. $-\mathrm{A}$ reef and shoal water extend off Remedios point for nearly a mile in a southeasterly direction, the water shoaling from $4 \frac{1}{2}$ to $1 \frac{1}{2}$ and 2 fathoms.

Black rock, about 25 feet high, is close off the point.

East rock, about 8 feet high, lies $1 \frac{1}{5}$ miles S. $43^{\circ}$ E. (S. $49^{\circ}$ E. mag.) from Black rock. It is in the midst of breakers which extend from the shore, abreast of the rock, for one mile in a southerly direction.

Remedios rock.-The sunken rock off Remedios point, on which a German steamer was recently lost, and on which the sea breaks occasionally at low water, lies $2 \frac{1}{4}$ miles S. $39^{\circ}$ E. (S. $45^{\circ}$ E. mag.) of Black rock.

- Caution.-Vessels should not approach Remedios point nearer than 5 miles. A current $1 \frac{1}{2}$ knots an hour has been reported as setting to and around Remedios point to the eastward.

Coast.-A fter passing Remedios point, at a distance of 4 miles, a N. $87^{\circ} \mathrm{E}$. (N. $81^{\circ}$ E. mag.) course for a distance of about 30 miles will take a vessel $11562-13$ 
to the anchorage off La Libertad. After running 12 miles past the point, ten very noticeable bluffs will be seen separated by small beaches. There are no dangers along this part of the coast, and the shoalest water will never be less than 12 or 14 fathoms when 2 miles cff the bluffs. The country along the coast between the ports is called Costa del Balsamo.

The volcanoes San Vicente and San Salvador, situated somewhat inland, are a great assistance to the vessels bound into Acatajula and La Libertad, as they are visible from a great distance at sea.

La Libertad is the port of the city of San Salvador, and contains 1,500 inhabitants. It has an iron pier with hoisting gear, boat, ladders, etc.

The harbor is an open roadstead, and is exposed to the full sweep of the Pacific. The port can be considered safe in fine weather or from northerly winds, but should not be visited from July to October. At times the beach is smooth, but at full and change of the moon the rollers, which set in suddenly and are apt to snap cables unless anchored with a long scope, break at times in 4 or 5 fathoms at least $\frac{1}{4}$ mile off the beach, making the landing bad.

Supplies.--Poultry, bullocks, etc., can be obtained, but compared with those of Corinto the prices are exorbitant. Water is obtained with some difficulty from the small river of Chillama, about $\frac{1}{2}$ mile westward from the houses.

Telegraph.-The Central American cable lands here. To avoid fouling this cable do not bring the mole to the westward of N. $25^{\circ} \mathrm{W} .(\mathrm{N}$. $31^{\circ} \mathrm{W}$. mag.).

Steamers. - The Pacific Mail, the San Francisco and Panama line, and Champerico and Panama line eall twice a month going north and south, and the Acapulco and Panama line once a month.

Directions.-- When bound to this port from the southward, vessels should sight the volcano of San Salvador and steer with it, bearing N. $12^{\circ}$ E. (N. $6^{\circ}$ E. mag.), as it will lead to the roadstead. If coming from the eastward or westward, follow the coast about 5 or 6 miles distant.

Light.-From the west angle of the customhouse a fixed white light is shown. It is visible from 6 to 7 miles, and only shown when mail steamer is expected.

Coast.-From La Libertad the coast trends nearly ESE. for 33 miles to the mouth of the rio Lempa. The land, bordered with a belt of white sand, consists of an extensive plain, from which rises, in the distance, the volcanoes San Vicente and San Miguel; these are visible from a long distance at sea.

Rio Lempa, the current of which runs 4 or 5 miles an hour, is the. largest in San Salvador, but is navigable for river steamers only 24 miles The entrance is known by some large trees with white trunks and tops almost bare, which rise above the lighter colored and lower woods, simi- 
lar to the copse wood of northern countries. It may be found when coming from the eastward or southward, by bringing San Salvador volcano to bear N. $45^{\circ}$ W. (N. $51^{\circ}$ W. mag.) or San Vicente N. $16^{\circ} \mathrm{W}$. (N. $22^{\circ}$. W. mag.) and then running on either of these bearings will bring a vessel up to the bar. Coming from the westward San Miguel bearing N. $66^{\circ}$ E. (N. $60^{\circ}$ E. mag.) will bring a vessel up to it.

The entrance is about $\frac{1}{2}$ mile broad, barred by breakers which reach a mile or $1 \frac{1}{2}$ miles off. It is unimportant, and there are only a few fishing huts on its left bank.

A shoal at the mouth of the river extends $\frac{3}{4}$ mile off shore.

Rio Jiboa is about midway between La Libertad and rio Lempa. It is the outlet of lake Ilo Pango, but is closed by a bar with heavy breakers.

La Concordia.-One and a half miles from the mouth of the Jiboa is the entrance to the lagoon of Jaltepeque. At the mouth of the lagoon is the port or anchorage of La Concordlia, which has lately been opened to foreign commerce.

Coast.-From the mouth of the Lempa the coast trends about E. by S. for 20 miles to Lempa shoals.

Lempa shoals.-Properly speaking, this is not a "shoal" but a horseshoe bar, which is continually shifting and extends nearly 4 miles off the mouth of the bay of Jiquilisco or the bahia del Espiritu Santo of the natives. The shoals break in rough weather. The rise and fall of the tide is about 10 feet and a vessel of moderate draft can cross by taking advantage of tide, wind, and sea, having previously sounded and marked the channel.

In passing the shoal from east or west the lead is a good guide, for in the vicinity the soundings gradually decrease to the edge of the breakers.

In passing, it is not prurlent to go within the 10 fathom line:

Jiquilisco bay.-As above stated, the mouth of the bay is obstructed by Lempa bar, the depth on which, in its shallowest part, does not exceed 2 or 3 feet at low water. The harbor inside is extensive and deep, from 6 to 9 fathoms. Its length is from 15 to 20 miles and its.breath varies firom $1 \frac{1}{2}$ to 3 miles. It has in it three habitable islands, the largest of which is 5 or 6 miles long.

The bar at the entrance is reported as having a depth of 22 feet at slack high water.

Caution.-In passing along this part of the coast from Lempa shoals to Amapala point the distance of the coast line and line of breakers is deceptive, and it should be approached with caution:

Rio San Miguel is 5 miles eastward of Lempa shoals, but, like the other rivers, it is closed by a bar with heavy breakers. There is a small shoal at the mouth of the river. Inside the bar the water is deep, communicating with Jiquilisco bay. 
Coast.-From Jiquilisco bay the coast trends easterly for 34 miles to Amapala point. The soundings from a distance of some few miles in the offing are believed to decrease gradually to the shore, and vessels may anchor off the coast if overtaken by a calm, which it is perhaps most prudent to do, the currents being variable, sometimes to eastward and sometimes to westward, with a strength of about $1 \frac{1}{2}$ miles an hour.

Amapalu point is a low flat point about 4 miles long and from one to 2 miles broad, bordered by a reef of rocks and sand extending some distance out to sea and causing heavy breakers. Outside the point at a short distance there is a depth of from 6 to 8 fathoms.

From the point the shore bends in northwestward to the outlet of a small river and then turns northeastward 9 miles to Chicarene point, round the north side of which is La Union.

Conchagua volcano is 3 miles inland in a WSW. direction from Chicarene point and is 4,293 feet high. It has not the conical form characteristic of the volcanoes of this part of Central America. It is a large mountain with two summits contiguous to it, of which the higher has a gradual slope and is in parts crownerl with trees, whilst the other, of a very rounded form, is covered with the herbs named sacate. The second summit is the true crater and has been inactive many years; it is 3,972 feet high.

The volcano presents a remarkable appearance and when coupled with its nearness to the sea it can not be mistaken for any other mountain on the coast.

Port La Union, the western arm of the gulf of Fonseca (subsequently described) is a capacious and landlocked harbor.

On the north side of the bay are extensive mud flats that contract the channel in places to less than a mile in width, while another in front of the town uncovers at half tide, virtually cutting off all communication with the shore. This flat has encroached upon the anchorage since Sir Edward Belcher's survey was made, diminishing the depth slightly and shifting the channel a little to the northward.

La Union, the port of San Miguel, is situated on the southwestern shore of the bay, $4 \frac{3}{4}$ miles above the entrance. A small pier facilitates landing at high water. The population is estimated at 2,000. Coffee, cotton, hides, and balsam of Peru are exported.

The United States is represented by a consular agent.

Supplies.-Beef, poultry, and oysters can be obtained at reasonable rates. As ships find great difficulty in watering here, it is recommended to anchor and fill up at the spring, one mile below Chicarene point.

Light.-On the end of pier a fixed white harbor light is exhibited at an elevation of 33 feet and is visible 7 miles. It is not always exhibited. 
Directions. - If bound for La Union, keep to port of all the islands and steer to come between Conchaguita and the western shore under the volcano of Conchagua. When fairly in mid-channel the entrance to the harbor will be seen ahead between Punta Sacate island on the right and Chicarene point, which terminates the eastern slope of the volcano, on the left. Steer nearly for the point, and even bring it a little on the starboard bow if the flood tide is running, as it set across the shoal north of Conchaguita. As the point is approached open it a little from the north end of Punta Sacate and run past, giving the island the widest berth, as there is a rocky patch, Sacate reef making out from the SW . point.

It has been recommended to keep Chicarene point close aboard, but a steamer drawing 15 feet touched a rock in doing so; therefore a safe rule would be to keep a little to the westward of mid-channel. During the springs the tide runs through the pass at the rate of 3 knots an hour.

Maguera, Conchaguita, Perez, and Punta Sacate islands all belong to San Salvador.

Tides. - The tides are regular, except in the rainy season, when the ebb continues rather longer than the flood. At the entrance of the bay, between Chicarene point and Punta Sacate, the ebb sometimes runs at the rate of 3 knots and causes a strong race which has the appearance of breakers; in the vicinity of the town the rate is seldom more than 2 knots. 


\section{CHAPTER VI.}

THE GULF OF FONSECA AND THE COAST OF NICARAGUA.

General remarks.-During the dry season, which begins in November and lasts until May, the weather is fine on the Pacific coast of Central Anıerica. A light land breeze generally springs up before midnight, and in the forenoon the sea breeze sets in and lasts till sunset. Opposite the lakes Nicaragua and Managua violent winds, called Papagayos, varying in direction from NNE. to ENE., come after the rainy season is over, and reach their maximum of strength in December or January; these are often accompanied by a clear atmosphere and a cloudless sky. Sir Edward Belcher, R. N., remarks that their full force is seldom felt more than 20 miles from the land, and M. de Laplin recommends keeping 30 and even 45 miles from the shore, if it can not be coasted within 5 or 6 miles. The gusts are said to attain their greatest force during the forenoon, and to decrease about sunset; but too much dependence should not be placed upon this, since heavy squalls have been met with at night. The tendency of the wind, under certain conditions, to rush down the seaward slopes of mountain ridges should not be lost sight of by vessels keeping near the land.

In the gulf of Nicoya and on the coast below the Northers are sometimes felt for a day or two. Late in the season the sea breeze freshens considerably torvards sunset in and near the gulf of Fonseca. During the months of March and April the natives clear the land by burning the brush, and sometimes the smoke is so dense that the mountain peaks are obscured. The dry season is called by the Spaniards Verano de la Mar del Sud (summer of the South sea).

The rainy season lasts from May until November, but at first only occasional showers are experienced, generally in the afternoon. The officers of the Pacific Mail Steamship Company do not anticipate bad weather on the coasts of Nicaragua and Costa Rica before the middle of June. Later in the season calms and southerly storms prevail, the rain falls continuously, while thunder and lightning are at times incessant. Commander Wood, R: N, says: "From May to November, which is the rainy season, the weather is mostly bad; gales from the west and SW., with thunder, lightning, etc., being frequent, and at times violent." Other authorities refer to gales from the SE. and south as well. In his remarks about the 
anchorage at San José de Guatemala, Capt. W. H. Parker; Pacific Mail Steamship Company, says: "A southeaster brings in a heavy sea, and sometimes communication is impossible. This whole coast is at that season subject to very violent squalls of wind and rain, attended with heavy thunder and very vivid lightning. These squalls are called Chubascos", and they usually come from the eastward and southward and eastivard. The natives at Corinto expect a heavy southwesterly gale on or about the 4th of October, and an interval of comparatively clear weather between the 15th of July and the 15th of August.

Current. - The current during the dry season generally sets to the northwestward, but only off Guionos point, where the velocity is sometimes 2 miles per hour, does it run uniformly in that direction. The alternate currents on the coast of Mexico, that are felt as far east as Cocos island, are said to give rise to counter currents inshore, but the officers of the Pacific Mail Steamship Company have never remarked a steady southeagsterly set near the coasts of Nicaragua and Costa Rica during the rainy season. The force of the current off Guionos point would indicate some local agency, and, as it is strongest when the Papagayos are blowing, it may be that so much water is driven out of the gulf to the westward that an influx is occasioned. Crossing the entrances of the gulf and bays, the tides will be felt, and the set should be allowed for during thick weather or at night.

The gulf of Fonseca, sometimes called Conchagua, contains the port of La Union, in San Salvador, and that of Amapala and San Lorenzo, in Honduras, and is the outlet of the estero Real, a navigable river of Nicaragua. The entrance to this gulf is plainly marked by the volcanoes of Conchagua and Coseguina.

There are a number of islands in the gulf, but only the largest and those that by their situation affect the approaches to the inner waters of the gulf need be mentioned.

The Farallones are a group of light-colored rocks, the largest in the center, having a rounded top, while the others are sharp and jagged. It would be prudent to keep $\frac{1}{2}$ mile from them. They are $5 \frac{1}{2}$ miles westward of Monypenny point.

Manguera is the most seaward of the islands in the gulf. It is oval in form, its shores are cliffy, and it rises to a height of 1,660 feet. The eastern side has a sandy flat of 12 to 15 feet extending from it $\frac{1}{2}$ mile, beyond which are soundings of 4 and $4 \frac{1}{2}$ fathoms; south of it is a rock on which the sea asionally breaks, but from all nther directions it can be approached close to. () ff the SE. point is the small island of Manguerita or Perigallo.

Conchaguita, 2 miles northwestward of Manguera, is almost circular in form and has an elevation of 1,680 feet. The central peak throws out 
spurs to the north and south, and these shoulders are well defined when approaching from the west and SW. From the NE. side a flat extends all the way to Perez. There are no other dangers near it. The channel westward of it has 6 and 7 fathoms in it, while that to the southeastward, the one usually followed to Amapala, has a depth of from 8 to 11 fathoms.

Perez, $2 \frac{1}{2}$ miles northeastward of Conchaguita, is situated on the western edge of the flat extending from Conchaguita in a northeasterly direction to Disposicion, and northwards to the shore. The flood here sets northeastward and has a tendency to carry vessels towards the flat.

Punta Sacate is of an irregular shape. Sacate reef extends southwestward for over $\frac{1}{2}$ mile from the $\mathrm{SW}$. point of the island; it is never entirely covered, and presents no great danger. Between the island and the shore northward of it there is no safe passage, almost the whole space being occupied by a mud flat which dries at low water. At a short distance from its east side is an islet named Chiquito.

Garova, Disposicion, Sacate Grande and Tigre islands are eastward of those just mentioned. These islands are all more or less situated in the northern part of the gulf, and among them are many islets and rocks of which no special mention need be made.

Sacate Grande, or Velasques island, is the largest in the gulf, and the only one not densely wooded to the sunmit. Several of its peaks are 2,000 feet high and covered with grass.

Tigre has an extent of about 3 miles, and is almost circular in form. It is the highest of the islands in the gulf and its summit has an elevation of 2,490 feet. A bank of $2 \frac{1}{2}$ fathoms extends 2 miles from its SW. side, in the direction of Manguera, leaving between it and that island a channel $2 \frac{1}{4}$ miles wide and about 4 fathoms deep ; the east side of the island, in the direction of San Lorenzo, is so shallow that it is only for a short distance that vessels can get near it ; its north side is unapproachable, and it is only on the west that Amapala can be approached.

Knob island is close to the western side of the Tigre, and 325 feet to the westward of it is a pinnacle rock marked by a portion of a wreck. A bank has formed around this rock and appears to extend towards Knob island. The tide at a quarter ebb sets past the rock at the rate of from 2 to 3 knots an hour.

Amapala, the only accessible port of Honduras on the Pacific coast, is on the NW. end of Tigre island, which protects it on the south. The town, which has a floating population of 2,000 , occupies a narrow shelf on the north side of the island at the foot of Tigre mountain. There is a wooden pier, 400 feet long, extending out from the center of the town; the beach is steep, and lighters can load with facility. All trade with the interior is carried on by means of boats through Cismuyo bay and the 
esteros leading into it. The principal exports are silver and gold in bars and ores. Pacific Mail steamers call regularly.

The United States is represented by a consular agent.

Supplies.-Fresh beef and poultry are plentiful; oysters and fruit are to be had at times; vegetables are scarce. Water can be obtained from wells; it is said to be abundant and of good quality.

Port charges.--Nanifest, $\$ 2$; tonnage dues, 25 cents per ton.

Anchorage.-The captains of the Pacific mail steamers state that the best anchorage is immediately off the end of the pier and somewhat inshore of the anchorage indicated on the chart. Reports state that there is less water at the anchorage than shown on the chart.

Landing.-The boat landing is at the outer end of the pier, where there is always plenty of water.

Directions.-Making Amapala from the westward, steer for midchannel, between Conchaguita and Manguera islands, so as to bring the high conical peak of Tigre between then, then run directly for it, taking care not to be swept by the flood north of a range between it and the southern end of Conchaguita island, as there are shoals on the port hand. When Disposicion has fully opened from Sacate Grande the shoal will be passed and Tigre island will be a mile distant.

The channel west of Tigre is about $\frac{3}{4}$ mile wide, and when in the lead should be freely used, as the edge of the bank is steep. The rock off Knob island is at present marked at low water by the steam drum and boiler of the wreck on it. When approaching the port the direction and influence of the tidal stream must not be forgotten. The flood sets north and towards the bank.

The best time to leave Amapala is at the end of the flood and with a land breeze.

Coning from the eastward, having doubled Coseguina point, steer to the northward, passing the Farallones, not closer than $\frac{1}{2}$ mile, and the little island of Marguerita, and then bring the latter on a range astern with the westernmost of the Farallones.

Cismuyo bay, 3 miles north of Amapala, with the entrance between Sacate Grande and Disposicion islands, extends beyond the islands into the mainland, but its shores are low, marshy, and covered with mangroves. Near the head is La Brea, a small collection of huts, connected with Tegucigalpa, the capital of Honduras, by road; here all merchandise to and from Amapala is transshipped by boats.

Tides.-At the north end of Manguera the flood sets ENE. with a strength of about a knot an hour; the ebb, on the contrary, flows between Conchaguita and Manguera SSW. at the rate of $1 \frac{7}{10}$ knots.

San Lorenzo.--East of Tigre and Sacate Grande islands is San Lorenzo bay. This insignificant village of the same name is situated on the 
left bank of a narrow, tortuous estero, 3 miles above the head of the bay. The bay can never be made available for commerce until the narrow channel leading into it is lined with buoys and beacons. Three fathoms can be carried in at low water, but in several places the width of the channel is little over 200 yards. For 6 miles the course is amongst banks and shoals before it nears any point sufficiently to make bearings available. With the chart, vessels drawing under 12 feet might enter, but there is still danger, as the channel shifts ; several places were noticed in which the tide flowed with considerable force across the banks. Large ve:sels should not attempt it without planting buoys, at least betwcen the bar and Raton island. Above Raton the channel is wide, and can be easily navigated; here the anchorage is always good, for, though the bay is open to the entrance of the gulf, the shoals and flats form an excellent breakwater. The sea breeze raises the water at the head higher than at any other place in the gulf; on one occasion a rise and fall of 14 feet was noticed. The western shore of the bay above Sacate Grande island, and all the eastern except a small strip on Raton island, is lined with mangroves. There are numerous esteros, but in none of them except that of San Lorenzo can boats penetrate beyond the low swampy land. From San Lorenzo bay to the mouth of the estero Real the shore continues low, and the water is so shoal that at one point only 3 fathons can be carried to within 2 miles of the land. The natives call this place Condega, and it is reported that several vessels have loaded here with dyewood. Several rivers enter the gulf betreen Condega and the estero Real, but they are either choked with bars and mud flats, or they are too shallow, after a few miles, for anything but lighters and small boats.

The estero Real.-This broad navigable river enters the gulf near the head of the large bay behind Coseguina volcano. On the bar there are $2 \frac{1}{2}$ fathoms at low water, and from the mouth to the junction of the estero Palomina, 20 miles above, the depth is sufficient for the largest ships. $\mathrm{Up}$ to this point the tides are but slightly affected by the river currents, consequently there is but little trouble in ascending with the light prevailing winds. Above it the depth diminishes rapidly, and $1 \frac{1}{2}$ miles farther on the stream is compressed between two rocks. Dyewoor, the only article of commerce, is cut and shipped in large quantities; the country contiguous to the water courses is being rapidly stripped of it. Little in the way of supplies can be obtained on the estero. Ducks, curlew, and pigeons are plentiful. There is a spring near Nagascol, and another at Tampisco that uncovers at low tide, but the flow is so small that ships should water if possible before entering the river.

The large bay into which the estero flows has shoals and flats over nearly all the upper portion, and the channel leading across them begins properly $7 \frac{1}{2}$ miles above Monypenny point. Having reached this point, steer 
S. $34^{\circ}$ E. (S. $40^{\circ}$ E. mag.) until Conchagua volcano is just inside the shore line on the soutli side of the bay, and then steer on this range. The shore astern being low when the point selected dips, edge off to the southward so as to keep the volcano at all times in range over the visible land. To insure this change in range, the height of the eye should be less than 20 feet. This will keep the vessel in the curve of the channel until the mouth of the estero is fairly open, and when you can see well up the first reach, starboard and run in.

Eight miles above the mouth, on the left bank, is Playa Grande, consisting of a customhouse and one or two huts. Five miles farther on the stream is narrowed between two ledges, but by keeping, in mid-channel they will be avoided. Thus far the banks have been low and the country level, but 4 miles above the narrows. Nagascol hill rises from the soutly bank of the river, and a little above it ships generally lie while loading. After two or three bends a 2-mile reach succeeds, and at the upper end the estero Palomina joins the main stream. The Tampisco creek also flows into this reach from the southward, $\frac{1}{2}$ mile below the junction.

Directions.-Entering the gulf of Fonseca from the westward, keep at least a mile from Amapala point, and do not go inside of 5 fathoms while running up the western shore; if from the eastward, pass Coseguina point off, and if bound for the estero Real, keep about that distance from the shore until the Farallones are abeam.

\section{NICARAGUA.}

Nicaragua extends from the gulf to Fonseca to Salinas bay in the gulf of Papagayo. Its population, estimated, in 1883, at 350,000 inhabitants, of whom $\frac{1}{20}$ are whites, produce, or require comparatively little from the rest of the world. It is of importance on account of the magnificent line of lakes and of the proposed ship canal across the isthmus. The northern part of the republic is mountainons, but the southern part is a vast plain in which lie the lakes, being about 200 miles long and 100 miles broad. The sierra Madre range, with many volcanic peaks, passes through the western part, broken by the above valley, and the lakes leave but a narrow neck of land between them and the Pacific coast.

Managua, the present capital, contains about 18,000 inhabitants.

Canal.-The proposed canal route, from Greytown on the Atlantic coast to Brito on the Pacific, is 169.5 miles in length. The summit level is lake Nicaragua, 110 feet above tide water. This is reached by means of three locks on either side. The canal is to have a bottom width of from 80 to 120 feet, and an upper width of from 80 to 288 feet. The depth is to vary from 2$\}$ to 30 feet. Of the entire route 142 miles are included in the San Juan river, the lake, and in artificial basins. The total length of the summit-level reach is 151 miles, and will be available for rapid nayigation. 
Port charges.-Tonnage dues, 10 cents per ton; lighterage, $\$ 1$ per ton; pilotage, $\$ 3$ per foot draft.

Monypenny point is 12 miles northeastward of Coseguina point, the SE. point of the gulf of Fonseca. The point is low, but the water is deep close to, and the anchorage to the eastward, where vessels may wait before attempting to enter the estero Real, is well sheltered.

Coseguina point-Volcano.-Near the point is the celebrated volcano Coseguina. The verge of the crater is $\frac{1}{2}$ mile in diameter, and thence the interior walls fall perpendicularly to a depth of 200 feet, when the bottom of the crater become flattish, with a small transparent lake in the center. It was last in erruption in 1835 .

The summit of the volcano is 2,830 feet high, and it can be seen at a distance of 70 miles in clear weather.

Viejo or Chinandega, 5,670 feet high, 36 miles from Coseguina and 17 miles inland, is next to Ometepe, the highest mountain in Nicaragua, and is directly back of Corinto, or Realejo, which is the most important seaport. The summit is very sharp, and in appearance has been cut off at an angle. On the west side two small peaks rise near the base, while on the other side a high ridge shoots out for 2 or 3 miles and then sinks down to the foothills. Viejo is really the first of the Marabios range, which extends nearly ESE., and terminates in the volcano of Momotombo. The volcanoes of Telica, San Jacinto, Rota, Las Pilas, and Assoco are also included in this range, but as Viejo and Momotombo are higher than any between them they alone are especially valuable as landmarks.

Momotombo, 3,910 feet high, is a conical mountain, so regular in outline that it can not be mistaken for the lower and more rugged peaks to the left. At present it shows signs of activity, and smoke is often seen issuing from the summit.

Cerros de Managua.--This long rounded ridge shows a regular curved outline for nearly 15 miles, and is SE. of Momotombo and parallel to the coast.

Mombacho is very irregular in outline and shows two peaks, when seen from the westward, over the cerros de Managua, and three from the southward. The eastern summit is the highest and is remarkably sharp. It is 4,305 feet high.

Ometepe is in the lake of Nicaragua, and over the high land to the Pacific shows a perfect frustum of a cone. It is active, 5,680 feet high, and often concealed by dense volumes of smoke. The little port of San Juan del Sur is directly in front of it on the coast.

Madera is a saddle-shaped mountain, the eastern and higher summit of which has an altitude of 4,681 feet.

Vessels making the land in front of Ometepe and Madera will have the mountains of Costa Rica in sight to the eastward. 
Coast.-From Coseguina point the coast of Nicaragua preserves a general direction of SE. to the eastern boundary at the head of Salinas bay. The volcanic peaks and mountain ranges near the sea are so distinct in outline or surroundings that they are easily recognized when approaching in clear weather, and as occasionally they become visible during the rainy season, when observations have been obtainer, the advantage of being able to distinguish them can not be overestimated.

From the point, the shore for the first 6 miles, sloping gradually from the base of the voleano Coseguina, breaks squarely off into the sea and forms an almost perpendicular line of cliffs 200 feet in height. The hills here recede from the shore and 9 miles from the end of the bluffs is a lagoon, or river mouth, with an island across it and shoal ground $\frac{1}{2}$ mile out, on which the sea often breaks.

Speck reef, consisting of shoal patches with deep water about then, extends 2 miles along the beach and makes out $1 \frac{1}{4}$ miles. At the western end, one mile off shore, are several rocks awash.

Burra Grande reef.-Between this reef and the shore is a narrow channel with 5 and 6 fathoms, but, owing to shoals, this passage should never be attempted.

Limon or Bubosa island is evidently the Manzana and False Cardon of Belcher and De Laplin. Over it the sea often breaks, and it is low, flat, and covered with trees, with small bight behind it full of dangers. It is said that a number of vessels have been lost on Burra Grande reef, or amongst the shoals close to Limon island, by mistaking the latter for Cardon island in front of Corinto. The lighthouse on the Cardon island and the fact that Limon is densely wooded before it can be made out as an island, while Cardon is comparatively bare, should prevent such disasters in the future.

Corinto harbor is formed by the junction of the Realejo river and the estero Dona Paula, and extends around the southeastern end of Asserradores island, between it and the mainland on the east and south, and Cardon island on the SW. It was formerly called Realejo from the village of that name several miles above the anchorage. Asserradores island is often referred to in descriptions of the port, but it should be borne in mind that separated only by a narrow creek it can never be distinguished from the mainland. It is low, level, and densely wooded, with a narrow sand beach along its whole extent.

Cardon island is of a reddish brown color, almost bare of trees, about 3.5 feet high, and nearly level. 'The northwestern end, known as Cardon head, is faced with perpendicular rocks, and just outside of them is Ponente rock, resembling a tower. As Cardon island is outside of and SW. of the lower end of Asserradores island, and nearly parallel to it, the main entrance to the port, called Cardon channel, is open to the N W. between them. 
Castanon bluffs are 47 feet high; to the eastward are several wooded hills of twice that elevation.

Cardon channel is the only one now used in entering the port. The dangers to be avoided are the rocky patch that makes out to the westward, rather more than 200 yards from the upper end of Cardon island, and Sawyer bank, which extends to the westward from the lower end of Asserradores island, and contracts the channel under Cardon head to a width of 700 feet. A vessel drawing under 18 feet can avoid hauling sharply around Cardon head into the narrow channel, by standing inshore a mile or more NW. of the port until she has the entrance well open to the southeastward. When running in, one of the hills on Pemta Scaco peninsula showing to the left of the lighthouse should be selected and used as a range, the set of, the tides being nearly east and west. The rocks under the lighthouse can be passed within 50 fect, but it is better to keep 100 yards off" as a little helm may be necessary on account of the eddy just inside the head. When directly between Icacos point and the southeastern end of Cardon, steer to pass Icacos within 200 yards. As it is rounded the town will come into view, when anchor in front of it in 5 or 6 fathoms 300 yards from the shore, and reer to a short scope or moor.

With a heavier vessel, or when there is any sea on the bar, it will be necessary to keep nearer Cardon island while approaching the entrance of the channel.

When a heavy sea is running it would be unsafe to cross, as there are patches on the bar with only 4 fathoms over them at low water. If obliged to anchor outside and wait for a pilot let go to the westward of the light, where there are from 5 to 8 fathoms within a mile of the shore and gradually deepening.

Caution.-The flood tide sets strongly across Sawyer bank.

Barra Falsa channel is the narrow entrance to the port between the bluffs and the southeastern end of Cardon island. The depths in this channel are constantly changing. In the spring of 1884 a large French merchantman, mistaking the entrance of the port, ran in through the Barra Falsa, but its use, even with the chart, is not recommended.

The principal danger outside of Corinto is the Conway reef to the southeastward.

Castanon shoal has only $3 \frac{1}{4}$ fathoms over it, therefore vessels coming from the eastward should keep 2 miles from the land, or in 12 fathom's, until the reef is passed, and then haul up to pass Cardon island a mile off: The range of Castanon bluff's and the lighthouse will carry clear of Conway reef, but unless acquainted with the port it will be difficult to distinguish the bluffs from Cardon island beyond them.

The landmarks for making the port in clear weather are the volcanoes of Coseguina, Viejo, and Momotombo; Viejo, owing to its height and 
position, has been seen by vassels 50 miles outside of Corinto. All the peaks between Viejo and Momotombo are visible from the offing, and as the port is neared Assoco will come nearly in range with Momotombo and become like it, conical in appearance. For a considerable distance, above and below Corinto, the coast is low, and back of it is an extensive plain rising towards the interior.

Corinto, situated on the eastern or inshore side of Asserradores island just beyond Icacos point, has a population of 800 , and a steady increase seems assured. A railroad through the cities of Chinandega and Leon connects is with Leon Viejo, on lake Managua, and as one is proposed between the cities of Managua and Granada, communication by rail and steamer may soon be established with lake Nicaragua and the Atlantic. During the year 1883 forty sailing vessels arrived from foreign ports and the $\mathrm{Pa}$ cific mail steamers stopped on an average once a wcek.

The United States is represented by a consular agent.

The principal exports are coffee, sugar, hides, dyewoods, mahogany, and cerlar.

Imports, flour, cotton, and silk stuffs, agricultural implements and machinery.

Supplies, except vegetables, can readily be obtained. Water is procured by sailing boats up one of the creeks above the town, or lighters can be hired for the purpose. Vessels often coal here, but too much dependence should not be placed upon finding it.

Light.-A fixed white light is shown on the north end of Cardon island at an elevation of 64 feet and is visible 13 miles. The light is obscured in the harbor between S. $18^{\circ} \mathrm{W} .\left(\mathrm{S} .12^{\circ} \mathrm{W}\right.$. mag.) and N. $49^{\circ} \mathrm{W} .\left(\mathrm{N} .55^{\circ}\right.$ W. mag.).

Conway reef is $2 \frac{3}{4}$ miles southeastward of Castanon bluff. The two rocks above water, 8 and 5 feet high, are distant from the beach a little more than $\frac{3}{4}$ mile. The ground between these rocks and $1 \frac{1}{4}$ mile to seaward of them, and probably a greater distance, is very uneven. In passing the reef a berth of at least 2 miles should be given the rocks abore water.

Tamarinda river, about 42 miles southeastward of Corinto, is narrow and tortuous, with less than. 2 fathoms on the bar. Occasionally a ressel loading with dyewood anchors within a mile of the beach, in 5 or 6 fathoms, and takes on board all that the natives have cut and floated down. It is reported that a schooner once went inside. The best mark for the river mouth is the Loma de Tigre, a table mountain 8 miles inland, the flat top of which has an extent of one mile from north to south and $\frac{1}{2}$ mile from east to west. It is 1,060 feet high.

Cape Desolado, the northrestern limit of the gulf of Papagayo, is a conspicuous headland, and owing to the low land just to the southeastward 
appears at a distance to project well into the sea, but in reality the change in the direction of the coast is very slight. The cliffs, ending at the point, are over 200 feet high, and just to the northward part of the ascent is faced by a smooth perpendicular rock, back of which the rise is gradual to the summit of the ridge. The highest point, $\frac{1}{2}$ mile inland, when discovered from up the coast, shows several knolls on the seaward slope, and outside of these the headland soon rises. From down the coast the face of the hill towards the interior appears to be steep, the other to descend gradually until near the shore, when it rises and then falls suddenly to the sea. When the cape bears N. $17^{\circ} \mathrm{E}$. (N. $11^{\circ} \mathrm{E}$. mag.) the Loma de Tigre and the volcano of Momotombo will be in range with it, but neither can be seen when close under the land.

Industrie rock lies $1 \frac{1}{4}$ miles, below the cape, and is just awash at low tide, and from this a reef, on which the Bremen bark Industrie must have struck, extends nearly one mile, with the depth over it varying from 6 fathoms to less than one fathom. None of the rocks lie quite as far out as the one first mentioned.

Gigante point, about 53 miles southeastward of cape Desolado is a remarkable sand bank, heaped up against one of the bluffs, and is concealed when approached from up the coast by a projecting cliff, but in front, or from down the coast, it can be seen for more than 12 miles. By moonlight, and when not in the shadow of the bluffs, it is very distinct.

Just beyond Gigante, and 4 miles inland, is a prominent mountain 1,555 feet high, which, from the westward, appears to be capped by a small circular eminence.

The coast in this vicinity is generally bold, some of the cliffs being almost precipitous, but at Brito, 7 miles north westward of San Juan, where there is a slight indentation backed by a sand beach, the land is low, and the depression extends through the hills towards the lake. Brito is the proposed terminus for the Nicaragua canal.

Port Nagascolo is little more than a recess in the cliffs, $1 \frac{1}{2}$ miles NW. of the signal station at San Juan. A vessel anchoring just inside the heads would be less than 200 yards from the rocks on each side, and shoal ground less than 400 yards ahead.

San Juan del Sur.-Formed by an opening through the cliffs, backed by a curving sandy beach, this port is still further contracted by the shallow water along the edge of the beach, while the entrance is narrowed by the rocky points under the cliffs. The opening of the cliffs to seaward outside of the rocks forms a bight about 600 yards deep. The water deepens gradually from the head of the bay to 5 and 6 fathoms between the rocks, and to 10 and 11 fathoms between the headlands. The bottom in some places is rocky, but generally consists of sand and shells. 
The bluffs overlooking the entrance are lofty and precipitous; that on the SE. side projects into the sea, with the narrow ridge at the summit running nearly north and south, and from this the sides and end descend, at first abruptly and then perpendicularly to the water. The signal station, a small square house with a flagstaff near it, stands on the highest point of the ridge and can be seen 6 or 8 miles. A small light is sometimes shown here, but vessels should not depend upon making it when running for the port at night.

The low land back of the bay is succeeded by the foot hills of the dividing ridge between the lake and the ocean, and $2 \frac{1}{4}$ miles from the beach is mount Papayal. When within 15 miles of this mountain a stranger can not fail to distinguish it by the knolls or mounds along the ridge, the outline resembling that of the left hand closed, with the knuckles uppermost and the palm turned away. When near the port the Frailes can be seen to the southeastward.

The village of San Juan stands on the eastern shore of the bay and behind the signal station hill, but several of the houses are visible to a vessel approaching from the westward. It is 10 miles from lake Nicaragua and about the same distance from the town of Rivas, with which it is connected by a good road. There is a small well-sheltered wharf for boats and lighters.

The United States is represented by a consular agent.

Supplies of all kinds; except beef, are difficult to obtain, also water.

Steamers.-The Pacific mail steamers call twice a month going each way, but there are hardly any other arrivals.

Light.--On the south point of entrance to the port a fixed white light is shown, which is visible 8 miles. The light is difficult to recognize from seaward on account of the trees, and very probably is only shown when the steamers are expected.

Directions.-There should be no trouble in finding the port in clear weather, nor in entering at any time, if the headlands are made. When well off shore the volcanoes of Mombache, Ometepe, and Madera, the peaks of Orosi, and the cerros Elena. will serve as landmarks. When the rocky points under the bluffs are made, anchor or run past them into the bay. Coming up the coast pass the Bat islands $\frac{1}{2}$ mile off, outside of cape Elena.

The harbor being open to the SW. the Papagayos blow directly out, and as the squalls are often violent, the bottom shelving, and the holding ground poor, vessels obliged to go inside during the season of these winds should anchor so as to clear the rocks if they drag. When not loading it is better to lie outside, and preferably near the south bluff.

$11562-14$ 
San Juan to Aranca Barba point.-The eoast is everywhere high and bold, with soundings varying from 10 to 20 fathoms $\frac{1}{2}$ mile from the beach. Three miles from the.signal station, and 800 yards off shore is the West Fraile, and one mile farther, and $\frac{3}{4}$ mile from the shore, is the Middle Fraile. They are nearly circular, less than 200 yards in diameter, steep sided, flat or oval topped, while 1,200 yards from cape Natan is the East Fraile, a steep, jagged rock, which, when seen from up the coast, looks like a sloop standing to the southward under all sail except gaff topsail; when in front this islet, owing to the high rock inshore of the same formation, it can not be readily distinguished. Five miles beyond Aranca Barba point the eastern boundary of Nicaragua is reached. The intervening portions of the coast are included in the shores of Salinas bay. 


\section{CHAPTER VII.}

\section{THE COAST OF COSTA RICA.}

Costa Rica extends from a point somewhere about Salinas bay to Burica point. The soil of Costa Rica is exceedingly productive, and, owing to the different elevations, products of both the temperate and torrid zones are grown. The cool lands are from 5,000 to 6,000 feet above the sea, among which several volcanoes shoot up, varying from 8,000 to 11,000 feet in height. The forests, which extend over a large portion of the Republic, abound in timber suitable for shipbuilding, also mahogany, brazil, and various other valuable dyewoods.

The cultivated portion of Costa Rica lies principally within the valley of the rio Grande, and in this district are fully seven-eighths of the inhabitants. The population numbers 213,785. San José, the capital, has a population of 25,000 .

Port charges. - Foreign steamers are free of tonnage, and only pay $\$ 10$ for entering and clearing. Sailing vessels pay 25 cents per ton register and $\$ 10$ for entry and clearance.

Landmarks.- South of Salinas and Elena bays the coast of Costa Rica projecting sharply into the sea at cape Elena, sweeps around to cape Velas, forming, by this change in general direction from that of the Nicaragua coast above, the gulf of Papagayo. The line of volcanic action, which presents so many distinctive land marks in Nicaragua, is prolonged through Costa Rica, but owing to the divergence of the coast line from it, only the mountains near the boundary line are of value to the navigator.

The Orosi.--The north and south peaks of Orosi, over 5,000 feet high, are united by a lofty ridge, which is often visible when the peaks are obscured.

Rincon del Volcan Vieja, 8 miles from Gongora, is occasionally active, and its sides, broken and deeply furrowed, differ from the other volcanic peaks of Nicaragua and Costa Rica.

Cerros Elena, a range of mountains, forming a remarkable headland, reach out into the gulf of Papagayo from the eastward. Seen from the westward this headland looks like a mountainous island, but from the north or south it shows an oval, serrated ridge, the outline resembling the edge of a half-open fan. Four of the peaks are over 2,000 feet in height.

Salinas bay.- This spacious harbor, formed by the doubling back of the coast, which sweeps it around with a regular curve from Aranca Barba 
point to Sacate point, belongs to both Nicaragua and Costa Rica, the boundary line entering near the head. The bay between the points is nearly $2 \frac{1}{2}$ miles wide and is about 4 deep. On the north the shore is.high and bold, but on the east and south sandy beaches, low marshy valleys, and bluffs occur at intervals. The peaks of Orosi and Rincon del Volcan Vieja overlook the hills back of the bay.

Nearly in the center of the bay is Salinas island, the southern acclivity being much steeper than the northern, and as both appear, when entering the bay, to rise unbroken from the water's edge, it resembles a wedge with the, point to the northward.

Except just inside the southern headland, the north and south shore have shallows making out for nearly $\frac{1}{2}$ mile, and while there are several ledges with rocks that uncover at low tide, none are outside of this distance. Close to the western point of the Salinas island is a detached rock, and 400 yards from the eastern point there is another with foul ground 300 yards to the southward.

Descarte point terminates the peninsula separating Salinas and Elena bays. Nearly $1 \frac{1}{4}$ miles from it is a rock above the surface, but so small that it can not be seen at high water until close aboard. A number of dangers were found between it and the point.

The trail from Costa Rica to Rivas and San Juan skirts the northern shore of the bay, and strikes into the hills $1 \frac{1}{4}$ miles east of Aranca Barba point. There is a cattle ranch close to the northern shore and another a short distance from the head of the bay.

Directions for entering Salinas bay.-Salinas bay can easily be found, as it occupies the northeastern angle of the gulf of Papagayo. Coming down the coast the entrance will be hidden by cape Natan, the shore apparently continuing unbroken to the head of Elena bay, but as the East Fraile is passed the port will come into view. Arriving from the southward, having passed punta Blanca at a safe distance, keep cape Elena showing outside of it, and the rock off Descarte point will be cleared; when Salinas island opens from Sacate point, port and run in. If the Orosi mountains are visible, bring the north peak to bear S. $72^{\circ}$ E. (S. $78^{\circ}$ E. mag.) and stand in on that course. Having entered, pass to the northward of the Salinas island and nearer to it than to the northern shore of the bay, and then, if to get shelter from the westerly winds, stand on towards the head and let go when the island bears north of west; but if the Papagayo is blowing, haul up and anchor as near the north shore as the depth of water will permit.

Elena bay, open to the westward between Descarte point and punta Blanca, is separated by a promontory from Salinas bay. A tongue of land divides the head into two small bays, the southern being known as Juanilla, and 5 miles west of this is another called port Elena. Except where it 
breaks at the entrance of port Elena, the southern shore of Elena bay for 10 miles presents a straight east and west line of high wooded bluffs or steep cliffs that terminate abruptly at punta Blanca.

Near the north shore of the bay is Despensa island; of its two elevations the southern is the higher and the northern the more abrupt. 'Two miles farther is another island called Juanilla. Southeast of the latter the depth is convenient for anchoring, but outside of it are soundings to 18 fathoms, deepening to 40 between the headlands. There is a reef between Despensa island and Descarte point, but otherwise the head of the bay is clear of danger.

Juanilla bay.-The tongue of land already referred to which forms this bay is nearly a mile in length, about that distance from the southern shore, and parallel to it. There are two small islands just off the end, and $\frac{1}{2}$ mile farther west is a low rocky islet, Vagares rock. In the passage thus formed are two dangerous rocks, but the channel between the islet and the south shore, a mile in width, is free from dangers, and therefore a vessel entering should approach from the westward and along the south shore of Elena bay. The bottom is mud and holds well. A small indentation on the south side, called San Tomas bay, affords the only protection from a westerly wind and sea.

Port Elena.-CThis fine landlocked harbor lies in a narrow valley under the cerros Elena and behind the cliffs through which the entrance leads. The entrance looks like a gorge, and being the only break in the cliffs east of punta Blanca, can easily be found. The loftiest summits of the cerros Elena are farther west towards the cape, but the ridge back of the port is crowned by two conical peaks that can readily be made out. Just outside the heads are two snall islands, Arriba on the east and Abajo on the west, but the latter is so near the cliffs that it can not al ways be distinguished when approacher from the northward. A small rock (Tooth rock) will be made as the entrance is neared, and must be left on the port hand going in. In the western angle of the bay a ledge makes out, while from the south shore extend sand and mud flats.

Directions.-Entering Elena bay from the southward, keep $1 \frac{1}{2}$ miles from punta Blanca to avoid the rock west of it; with this caution the directions given for approaching Salinas bay, on account of its proximity, will suffice.

To enter, keep $\frac{1}{2}$ mile from the cliffs until the entrance and the islands off it are recognized, when steer between the small rock and the western shore, and anchor anywhere inside.

Water.-The natives in the vicinity state that water can always be obtained.

Punta Blanca.-This bold and striking headland, sometimes called Elena point, projects to the westward, its rocky sides rising abruptly from the 
water to the sharp and jagged summit. The ridge it terminates is separated from the cerros Elena on the south by a narrow valley, which extends eastward and includes port Elena. Nearly 200 yards outside the point is a small rock 5 feet above water, and nearly a mile west of this is another 2 fathoms under water, with 20 and 25 fathoms all about it. To avoid this danger keep the Bat island open from cape Elena.

Playa Blanca bay.-This bight, though open to the westward, affords a shelter from the Papagayos, and, if it could be reached by a vessel overtaken by darkness when bound for San Jnan or Salinas bay, should be preferred to an anchorage under cape Elena. Three miles above cape Elena and a mile from the shore are two large rocks, and inside of them is an island.

Cape Elena.-Owing to its position and appearance this headland must be regarded as the most striking feature of the coast. It is a narrow rocky ridge, extending into the sea in a westerly direction nearly 2 miles, the sides rising abruptly from the water's edge and meeting sharply at the summit. A small island and some rocks above water lie close off the cape.

Murcielago bay is includer between cape Elena on the north and the Nurcielago or Bat islands on the south. It was surveyed in 18:38 by Sir Edward Belcher, R.N., and the following are his remarks, copied from Imray's Sailing Directions: "On rounäing the point in view, corresponding to the point Catalina of Banza, we discovered a cluster of eight islands. These I determined to examine, as they did not appear upon the chart. They almost formed two distinct harbors; the smaller islands forming a crescent by the south, one large island protecting the east and another of similar size forming the line of separation. Passing into the bay, we anchored in the inner or eastern harbor, and having fixed the positions, surveyed it, and completed watering at a very convenient position, where we anchored in 32 fathoms, with a hawser fast to the shore. We found the gulf squalls, even in this sheltered position, come down the gullies with great force, and impede our work as well as endanger our boats. The geological structure of the cape and islands is a schistose serpentine, containing balls of noble serpentine."

The Ranger anchored several times under the northeastern shore, between Rush and Ackerman, the two large islands above referred to, in from 12 to 15 fathoms, but, generally speaking, the bay is unsafe during the season of the Papagayos. On the lee side the islands have 30 fathoms or more close to, and the declivity of the bottom along the northern slope is so sharp that the anchors do not hold well. The gusts that come down the sides of the mountain are often heavy. As a rule, the Papagayos moderate towards sunset, but this is not always the case. 
San José, the largest of the Murcielago islands, is the third in the chain from the east.

Ackerman, thelarge island at the eastern end of the bay, has at $1 \frac{1}{4}$ miles to the southeastward (Piedra Negra) a low rock with deep water close to, which is almost connected by a reef nearly $\frac{1}{2}$ mile long.

Between the most westerly of the Murcielago group and the Little Bat islands are dangerous ledges.

The bay is occasionally visited by small vessels engaged in the pearl fishery. There is a spring on Cocine, the next island east of San José. It is doubtful if water can be found there later than February, but 30 yards from the beach and $\frac{1}{2}$ mile north of the low point on the mainland connected with the eastern end of Ackerman by a reef there is a fresh-water pond.

Directions.- To reach the anchorage from the north ward haul close round cape Elena, keep the Murcielago group on the starboard hand, and, passing to the southward of Rush island, separating the two bays, haul up a little, and anchor under the lee of the land with the west end of Ackerman bearing south (S. $6^{\circ}$ E. mag.).

Little Bat islands.-The larger of these rocks is about 200 feet in extent and 70 feet in height, with flat top and perpendicular sides. From it the smaller rock, similar in appearance, though with an opening showing to the southward and northward, is distant 200 yards.

Caution.-The ledges to the eastward suggest the existence of pinnacles along the submerged ridge, which the lead failed to find, and as the lead gives no warning of dangers, the passage between the rocks and the Murcielago islands should never be attempted.

Potrero Grande bay, open to the WSW. between high hills, widens a a little inside, but not enough to afford any additional protection to the anchorage. A sand beach curves around the head of the bay, and behind it is a lagoon which receives several rivulets from the surrounding hills, but as they are lost in the marshy ground along the borders, while the outlet is obstructed by shallows, vessels should not attempt to water here. A number of rocks show above water close under the heads; but there is.no danger outside of them.

Huevo bay and islands. - The bay is a small inlet, open to seaward, while the two islands on the north side lie so near each other and the shore that they appear to be high wooderl bluffs on the mainland.

Between the two last-named bays the coast recedes, forming a large open bight, in the northern part of which are reefs and outlying rocks. In the central part of the bight is a wooded platean 1,000 feet high.

Port Culebra is separated from Huevo bay by a narrow peninsula, 3 miles long, and terminating in Mala point, off which are the North Viradores, two flat rocky islets, with a rocky column near the center of the larger. This forms an excellent mark for vessels approaching from the 
northward. It will not be so readily discovered when coming from the westward, owing to the lack of vegetation on the steep face of Mala point beyond, in which direction lies one other islet. About $1 \frac{3}{4}$ miles south of the North are the Suuth Viradores, three small grass-covered islands, the outer one about a mile off Cacique point, which may be said to be the southeastern point of the port. Being fairly well defined against the wooded hills behind, the South Viradores serve as a mark for port Culebra and Cocos bay. The channel between them and Cacique point is foul and should not be attempted. From a line between the two points the port stretches over 4 miles in a northeasterly direction and is a mile wide at the narrowest part of the entrance between Mala and Buena points. It is spacious, secure, and easy of access, with water for the largest ships, and is one of the finest harbors in Central America. The shores are steep to and the water shoals very gradually towards the head of the harbor, over a bottom of mud and sand.

Cocos bay.-From Buena point the coast outside sweeps around to Cacique point, and then makes a deeper curve, forming Cocos bay, open to the NW., between Cacique and Miga points. Rocks and shoals extend off Buena point in a northwesterly direction to the 10 -fathom line.

Port Culebra and Cocos and Huevo bays were surveyed in 1838 by Sir Edward Belcher, R. N. He says: "Water fit for consumption was not found at the beach, but may be obtained a short distance up the creek, which a boat may enter at high water. Brazil wood is very abundant." As people are principally employed cutting the Brazil wool, probably all the mahogany and cedar which formerly grew near the beach has been hewn and shipped.

Directions. - Making port Culebra from the northward, having rounded cape Elena and the Bat rocks, steer S. $56^{\circ}$ E. (S. $62^{\circ}$ E. mag.) until the Viradores are made, when bring the pillar rock a little on the port bow and rum in between it and the South Viradores, hauling up to the eastward, around the rock, and so in through the entrance. Approaching from the westward, or from down the coast, having made Santa Catalina island, above cape Velas, and run by, keeping outside of it, past Brumel island and Gorda point, and then along the shore. The South Viradores will soon be made out under the land, with the entrance beyond and a little to the left, and the anchorage will be reached with hardly a change of course.

If intending to anchor in Cocos bay, bring the South Viradores about east, and run to within a mile of them, or until a long low building at the head of the bight can be seen, when steer in, keeping a little nearer Cacique point, as there are several ledges near the southwestern shore, and anchor in 8 fathoms.

Bramel islands.-About 2 miles SW. of Gorda point is a projecting point, sometimes called Gorda, which appears as a great rounded hill with 
a slight indentation in the midrlle of its summit; it is higher than the country in its vicinity, and its highest part is near the sea. Off this point are the Brumel islands. The two larger are covered with grass and bare of trees. Reefs extend north and south from the outer island and shoreward from the inner island. The extreme western end is apparently clear, and no dangers were found in the channel between the island and shore.

Santa Catalina islands are an important landmark and not easily mistaken. They have been usually considered as one island, the opening being seen when bearing NE. On every side a perpendicular wall of rock rises directly from the sea, and as the sloping face is covered with sacate, the resemblance to a stone fortification with tufted parapets is striking. The highest point of the island is 231 feet; the depth close to is nowhere less than 20 fathoms, while to seaward it increases in less than a mile to 35 fathoms. A bank extends $2 \frac{1}{2}$ miles to the southeastward, shoaling to 15 fathoms; and making with the coast a wide, 20-fathom channel.

Caution.-Scattered over this bank are several groups of pointed rocks that rise above the surface. Vessels should give these rocks a wide berth, never venturing. inside of a line from cape Velas to Santa Catalina islands, except to run through the channel referred to.

Protrero and Braxilito bays, open to the northward and westward, are in the angle of the coast between Brumel island and cape Velas and behind the bank SE. of Santa Catalina island. They are simply curves in the shore, separated by a high, wooded point, nearly a mile in length, with Eyre island close to its extremity.

Protrero, the northeastern bay, has several small islets, and near the head a shoal patch with rocks awash. A small house, the only one in the vicinity, stands, on the beach near the eastern angle of the bay, and a line through it from the middle of Eyre island between the two bays passes orer this shoal. When going in keep on the southwestern side and anchor where the depth is suitable, as the water shoals in gradually from 15 fathoms.

Braxilito, the south western bay, has soundings which diminish regularly from 16 fathoms, midway between the points of entrance, to 6 and 8 fathoms, $\frac{1}{2}$ mile from the shore, but inside this distance they are irregular, and on each side 800 yards from the shore are rocks under water, or part awash, 800 yards off. If intending to anchor within $\frac{1}{2}$ mile of the beach, do not allow Eyre island, between the bays, to shut out the point of land back of and nearest to Brumel islands, nor any of the group of rocks to close in with Santa Catalina islands; by keeping between these ranges the dangers on each side of the bay will be avoided.

Ships loading on the coast with dyewood, cedar, and mahogany visit these bays occasionally. The streams do not probably long outlast the rainy season. 
While the outlying bank does not prevent the sea from rolling in, the waves are more or less broken by the rocks, and these bays may be regarded as tolerably secure anchorages. Vessels may use either entrance to the channel leading in. From the northward run in between Brumel and Santa Catalina islands and steer so as to pass to the eastward of a small black rock, showing but little above the surface at high water. When on the range between Brumel island and cape Velas the rock will be passed, and the point separating the two bays being a little on the starboard bow the course can be maintained into Protrero bay.

Cape Velas is well wooded and some islets and rocks lie off it to the southward. Morro Hermoso, 769 feet high, is immediately back of it.

Gulf of Papagayo is scarcely worthy of the name; it extends from Velas to Corinto and is more familiar from the fact of the peculiar winds experienced off it. The Papagayo is a strong wind blowing from NE. to F. by $\mathrm{N}$. with a bright clear sky overhead and a glaring sun, with a dense atmosphere.

At Cape Velas Capt. Sir Edward Belcher lost the Papagayo; therefore he says, "The limits may be included in a line drawn. from cape Desolado. to cape Velas, and it is rather a curious phenomenon that the strength of this breeze seldom ranges so far as this chord, but seems to prefer a curve at a distance of 15 to 20 miles from the land."

In passing the gulf of Papagayo it is considered best to keep at 5 or 6 miles off shore rather than farther off; the squalls and calms are of shorter duration and less force at this distance than in the offing. Should this ccurse be impracticable, a distance of from 30 to 45 miles should be taken. In proceeding northward the wind will be found to veer more to the east.

Landmarks. - Between cape Velas and the gulf of Nicoya, the mountains are of moderate elevation and to a vessel in the offing they present few peculiarities of outline, but upon a nearer approach the cerros de San Blas will be made out above Guionos point, or Split peak, north of cape Blanco.

Morro Hermoso rises immediately behind cape Velas and, making an important turn of the coast, looks like an island when first seen from the southward, and is often the first point recognized by vessels entering the gulf of Papagayo when well over to the eastward. The sides have a regular and gradual slope, and the short narrow ridge running east and west has a slight depression, which gives it a saddle-shaped appearance; the eastern summit is round and the western sharp. Back of morro Hermoso are several hills of greater elevation, and when approached from the westward will first be noticed as a conical hill under them.

Cerros de San Blas.-A short mountainous ridge, 8 miles from and parallel to the coast, can easily be made out, as it is so much higher than land between it and the gulf of the Papagayo to the westward. The 
cone-shaped summit of mount Boughey will be seen a little farther down the coast, and between it and Split peak the coast range shows several points of equal elevation with no particular way of distinguishing them.

Split peak, 2,392 feet high, takes its name from the cleft which is distinctly visible from the westward and divides the summit, the south point being the higher. It rises north of the plateau behind cape Blanco and as it exceeds in altitude any of the peaks to the gulf of Nicoya may be regarded as the eastern termination of the coast range.

Coast.-Between San Francisco point and Guionos point detached black rocks will be found in many places, but, with the exception of these and shoals in the vicinity of Guionos point, there are no dangers over $\frac{1}{2}$ mile from the shore.

Guionos point from above and below shows a wooded hill with a gradual descent to the edge of the cliffs that overhang the sea. A rocky reef, making out from the point to the westward, uncovers at low water, and at all times the sea breaks over the mass of rocks at the foot of the cliffs. A little distance below the point the bluffs, with bare precipitous faces, are crowned by several wooded knolls. There are a number of dangers to navigation off this point, made serious by the great depth of water close to them, and by the NW. current, which here reaching its maximum runs in the winter at the rate of 2 knots an hour. Two and three-quarters miles from the point and 2 miles from the shore is a sunken rock, with 20 fathoms just inside of it and 50 fathoms within $2 \frac{1}{2}$ miles. A little more than a mile distant is another rock under water, with 15 fathoms close to it and 50 fathoms within $1 \frac{1}{4}$ miles. In calm weather the sea breaks over these rocks only at long intervals. There are other dangers in the vicinity of the point, but none of them are outside of a line between the two. just described.

The rocks above mentioned are said to form a continuous reef covering about the same ground as indicated on H. O. chart 1016 .

It is also said that current off Guionos point runs at times with great velocity, frequently setting directly on shore to the northward of the point.

Piedra Blanca bay.-The coast between Guionos point and the western point of the bay, 8 miles to the ESE., has off-lying rocks and reefs for almost the whole distance, but apparently they are all within $\frac{1}{2}$ mile of shore.

From the western point a reef of rocks extends SE. $\frac{1}{2}$ mile, leaving an entrance to the southeastward between the end of the reef and the extreme point of the bay. A vessel entering should keep close to the land on the eastern side, and in anchoring should let go far enough over to the westward to swing clear of a sunken rock nearly 600 yards from the extreme point of entrance. The water shoals gradually from 10 fath- 
oms. The best mark for the bay is Piedra Blanca, a large whitish rock 1,100 yards off the outer end of the reef, on the western side of the entrance.

Coast.-From Piedra Blanca the coast curves into the southward and eastward for a distance of 30 miles to cape Blanco, with the points of Quinones and Musimillama in between. It is apparently clear of danger outside $\frac{1}{2}$ mile from shore.

Quinones point, the extremity sharp and rocky, projects slightly into the sea to the westward.

Musimillama point is similar to Quinones point.

Cape Blanco is one of the most striking landmarks on the coast, especially when approached from the westward. Back or north of it a lower plain succeeds, which stretches to the foothills under Split peak, and while this remains below the horizon the more elevated plain resembles a long level island some distance from the land. Every other headland on the coast is irregular in outline, and Cano island (south), which alone can be said to resemble it, is so near the coast to the eastward that a mistake would be impossible. From the brow of the cliffs at the southern end of the plateau the distance to the extreme point of the cape is a little more than a mile.

Blanca island, 193 feet high and oval in shape, is a mass of whitish rock, rising abruptly on all sides, with a small patch of scanty vegetation at its highest point; and though no dangers were found near it, the use of the channel between it and the point is not recommended.

Gulf of Nicoya.-This large gulf is an important resort of trades and extends about 50 miles into the land in a northwesterly direction, with an entrance width between cape Blanco and Judas point of about 34 miles; it soon begins to decrease in width, and at its head is only 6 miles across. It contains numerous islands, all lying off the western coast, and vessels nxvigating the gulf pass to the eastward of them.

West coast. - It has already been remarked that the ordinary track of vessels lies to the eastward of the islands, and as the western shore of the gulf borders on an uncultivated and almost uninhabited region, it is seldom visited. Between cape Blanco and the Negritas islands the soundings increase rapidly off shore, but 3 miles above the cape a rocky reef, marked by a flat circular islet, makes out. Above the Negritas, and as far as Venado island, the depth is convenient for anchoring, but between the latter and the head of the gulf extensive shallows are found.

Ballena bay.-Having rounded cape Blanco and brought the western shore and Jasper island into view, Ballena head, a bold conspicuous promonotory, will be made out, and upon nearing it Ballena bay will open between it and several wooded hills to the southward. A low sand beach, broken by several entrances to the estero behind, sweeps around the head 
of the bay, and scattered along it, just above high-water mark, are a few native huts. The water shoals regularly over a hard sandy bottom. Running in, it is only necessary to keep $\frac{1}{2}$ mile from either point.

Negritas islands are two islands close to each other which run off $2 \frac{3}{4}$ miles from the coast ; from the eastern one a ledge of rocks extends $\frac{1}{4}$ mile to the eastward and has near its extremity a large rock known as Sail rock.

Gaution.-With light or variable winds sailing vessels should avoid getting too near this rock, as the tide runs past it with considerable force and the depth is too great for anchoring.

Coast.-From the Negritas the coast curves into the westward and northward and has several islands off of it; the largest, Cedro, is about 2 miles westward of the Negritas. At the next bend in the coast are the islands of Aves, Pan de Azucar, and San Lucas. Pan de Azucar is sometimes resorted to by vessels for shingle ballast, the anchorage being on the west side.

San Lucas island, with a small but secure harbor on the NW. side, was a few years ago made a convict station by the Costa Rican Government, and communication with it is forbidden.

At San Lucas island the coast makes a decided bend to the westward to the head of the bay, and off this stretch are Caballo, Vegieco, Venado, and Chira islands. The last named island is the largest in the gulf, and has anchorage $\frac{1}{2}$ mile from its northeastern shore. Nearly all the woods from the gulf are cut on the banks of the Tempisque river and its tributaries and floated down to Chira, where vessels load.

The Tempisque, a sluggish muddy river, empties into the gulf at the head, 6 miles above Chira island. It is navigated by a snall steamer from Punta Arenas as regularly as the tides admit, high water being taken advantage of, both for crossing the mud flats below the mouth and for ascending the river.

East coast.-Judas point, the eastern headland of the gulf, has a reef-Judas reef-extending from it in a southwesterly direction for over a mile. In approaching it directly, only the breakers on the reef serve to mark it, but from either side, when near the land, a wooded eminence will be made out above it, having a steep ascent at first, and then rising gradually to the highest point, $\frac{1}{4}$ of a mile inland.

Judas reef makes out from the point in a southwesterly direction, and shelving slightly and partially uncovers with the tide; the sea at all times breaks over detached rocks that show here and there above the surface. Vessels passing should keep at least 2 miles from the shore, and when just off the reef will have at that distance soundings in 10 and 12 fathoms. The existence and direction of a submarine ridge is indicated by this reef.

Cano island.-From Judas point the coast trends in a northwesterly direction to Cano island with Guapinol point, off which is Escollo rock, 
in between. The island lying close to the land, and connected with it by a reef bare at low water, is a prominent mark for vessels coming up the coast, appearing as a bold and lofty headland to the left of the Herradura mountains. It is a narrow, rocky ridge, perpendicular in direction to the line of the shore, the sides rising abruptly and terminating sharply at the crest.

Port Herradura.-Open to the westward, between Cano island on the south and Herradura point, a steep and rugged headland on the north, is rarely visited, communication with the interior being virtually cut off by the mountains that hem it in, while a sunken rock, nearly in the center, impairs its advantages as a port of refuge and an anchorage at the entrance of the gulf. The water is deep between the heads and the soundings are irregular for some distance inside; but near the beach across the head of the bay, and a little below the mouth of a small stream that affords an abundant supply of fresh water, the anchorage is good.

Havannah rock.-The danger above referred to was correctly located in 1856 by T. A. Hall, master R. N. The remark "breaks at half tide" appears upon the chart made from his survey, but as the officers of the Ranger never saw it break, even at low water, and as Belcher failed to discover the rock when he surveyed the bay in 1838, vessels running in, with the ordinary conditions of wind and sea, should depend upon bearings to avoid striking it. Along the northern shore of the bay are numerous detached rocks.

Coast.-From Herradura point the coast trends northward about $2 \frac{1}{2}$ miles to Sucia point, off which a rocky ledge extends for over a mile, with deep water close to the outer edge ; thence the coast turns to the northeastward for $4 \frac{1}{2}$ miles and then turns to the northwestward for 10 miles to Calderas bluff, back of which is port Caldera formerly of some importance, but now deserted. From the bluff the coast bends around northward and westward 8 miles to Arenas point.

The village of Agujas, above Sucia point, contains about thirty houses; and will be known by two detached light-colored rocks to the northward. Outside of the beach in front of the village is a ledge that uncovers at low tide, and beyond this the water soon deepens to 20 and 25 fathoms. The natives land at high water and haul their boats into the basin at the mouth of the creek south of the village.

Calderas bluff is bigh, steep, and covered with trees. In the northern portion of the bight it forms, and within one or 2 miles of the beach the depth is not too great for anchoring.

Arenas point has a bank of $3 \frac{1}{2}$ and $4 \frac{1}{2}$ fathoms extending from it in southeasterly direction for over 3 miles. On this bank are several 2 and $2 \frac{1}{2}$ fathom spots. The bank is steep $t_{1}$ on its western edge. The point has 
a shelf of mul extending about a mile westward from it, which is awash at low water. It forms the south bank of a small stream, which has its outlet immediately northward of it. On the north side of this river there is another shelf of mud which becomes dry at low water.

Punta Arenas (Sandy point) is not only the single port of entry in the gulf but the only place of any importance on the Pacific coast of Costa Rica. The channel leading up the gulf is to the westward of the bank making out from the western end of the peninsula. The outer anchorage, or roadstead, is on the eastern side of the bank and in front of the town, but as far east as Calderas bluff or the Barranca river the depth is convenient for anchoring. Though open to the entrance of the gulf, some protection is afforded from the rollers by the Negritas islands. The inner harbor, or the estero behind the town, is landlocked and perfectly secure, but is only used hy vessels of very light draft, and a pilot must be taken if intending to enter. Vessels entering the roadstead should keep the pier a little on the port bow to clear the tail of the bank.

The town, the seat of government of the province, is built on the sand point projecting into the gulf and is almost surrounded by water. It is regularly laid out and has a population of about 2,000. It has a small hospital to which all are admitted free. The port is connected by a welltraveled highway with San José.

The trade of the port has of late years greatly declined; San José, the capital, being now connected by rail with port Limon, on the Atlantic coast, while the construction of the Pacific division of the road seems to have been indefinitely postponed after the few miles between punta Arenas and the village of Esparta were completed. Coffee is the principal export, but there is some trade also in hides, cedar, mahogany, and dyewoods ; manufactured goods of various kinds are imported; tobacco, gunpowder, and saltpeter are admitted only on government account, and rum and firearms only by special permission ; mails arriving are first sent to the capital and then returned for distribution.

The United States is represented by a consular agent.

Supplies.-Fresh provisions and good native potatoes are plentiful. Water can be had ashore free, ships supplying their own boats and labor, or from the Barranca river, 5 or 6 miles to the SE., but at some risk to the boats in crossing the bar. Ballast is readily supplied.

Coal.-Some 400 or 500 tons of Cardiff are usually on hand, but the prices are high.

Pier.-The iron pier, the property of the government, is 425 feet long and about 30 feet wide, with an " $\mathrm{L}$ " on its west side. The pier is furnished with facilities for the rapid handling of freight. The Pacific Mail steamers anchor almost within 200 yards of the pier and abreast of it. 
Light.-A fixed white light is shown from the top of the shed at the end of the pier. The lamp is an ordinary one and the light is not to be depended upon. There are a number of street lamps of equal brilliancy.

Lighters.-All vessels discharge by means of lighters, of which there are ten, each holding about 300 tons.

Steamers.-The Pacific Mail call four times a month going each way. Two German steamers also call per month each way. A small steamer makes regular trips to and from the villages on the Tempisque river.

Mails and telegraph.-The mails for the United States and Europe via port Limon leave every week; for San Francisco, Cal., twice per month, and for Panama and the south four times monthly.

Punta Arenas is in telegraphic communication with San Juan, the nearest cable station, and with the rest of the towns in the State.

Pilots.-None are required; when vessels intend loading up the gulf a pilot is necessary, and the charges are $\$ 10$, Costa Rican money. When loading outside, the charges are $\$ 20$ for the trip. The Costa Rican dollar is about 50 cents, United States.

Harbor rules.-No communication can be had with the shore until after the visit of the captain of the port, and vessels must come in close for this visit. When the flag of the captain of the port is hoisted vessels must keep their colors at the peak. Vessels should not leave port for any purpose until permission has been received.

The charges for attending to a vessel's business is about 5 per cent on disbursements.

Directions.--The entrance of the gulf is marked on the west side by Blanca island and the plateau back of cape Blanco, and on the east by the termination of the nountain range that overlooks the coast below; the last spur, known as the Herradura mountain, rises abruptly from the eastern shore of the gulf.

Cerro Grande de Turubales, showing over the Herradura mountains when off the entrance and to the eastrvard of them from down the coast, is a prominent peak with a small conical summit; $2 \frac{1}{2}$ miles east of it is a mountain with a flat top nearly $\frac{1}{2}$ mile across; 20 miles farther east are mountains of still greater elevation.

The entrance to the gulf of Nicoya is so wide that no difficulty whatever is experienced in making it. It is usual to steer for cape Blanco, keeping a little eastward of its meridian, and afterwards to direct the course into the gulf; but it appears probable that some advantage would be gained if the land about port Herrarlura was made instead of the cape, as the effect of the westerly current would thereby be to some extent neutralized; a mile or two would also be saved in the subsequent route to Punta Arenas. 
Having entered the gulf, keep along the eastern shore, as it is shallower than the opposite coast, and also because the effects of the ebb stream, which, south of the Negritas islands, flows in a southwesterly direction, will not be so strongly felt. The soundings, although great, are not so deep but that the anchor can be let go in the event of baing overtaken with a calm and a contrary current. The flood has occasionally considerable strength, and requires to be guarded against, as its tendency is towards the Negritas islands, in the vicinity of which the water is very deep; close to the south side of the Sail rock the depth is 24 fathoms, deepening rapidly seaward to 36 fathoms. The course hence to Punta Arenas is direct, and by keeping the light to the eastward of N. $22^{\circ}$ W. (N. $28^{\circ}$ W. mag.) vessels will be clear of all dangers until the anchorage is reached. Both ebb and flood set strongly over the Punta Arenas bank.

In a steamer, having rounded cape Blanco at a distance of one mile, if bound into Punta Arenas, steer for Sail rock. If at night, pick up Jasper island, which is higher than the Negritas; and if very dark be sure and give Sail rock a berth, as it is not very high and can not be seen far. If the light is made after passing Sail rock, bring it to bear N. $22^{\circ} \mathrm{W}$. (N. $28^{\circ} \mathrm{W}$. mag.), run for it and anchor in 5 fathoms, sandy bottom. If, however, the light is not made (and it can not be depended upon) run over and make Calderas bluff, and then coast along in 6 fathoms until off the village; anchor in 5 fathoms.

By running close to Calderas bluff, and then coasting it, the shoals will be avoided, and if there are vessels here they will show clear of the point. These hints are only intended for night, as by day there is not the slightest difficulty in making this port. In the daytime run for the end of the pier, keeping it a little on the port bow.

In running for the port from the eastward pass Cano island (the SE. island of that name) 2 miles distant, and steer about N. $40^{\circ} \mathrm{W} .\left(\mathrm{N} .46^{\circ} \mathrm{W}\right.$. mag.) for Cano island No. 2. At a distance of 30 miles, by day, if the weather is clear, Cano island will be seen lying off a high mountain, and at the same time Judas point, a low point under the mountain, will be seen to the right. About this time Quepos point will be abeam, distant about 20 miles; this point looks like a saddle and is easily recognized. High land a little on the port bow, and, perhaps, cape Blanco broad off the port bow, will be seen. If a dark night do not try to make Judas point but keep on until Guapinol point is seen. This is a bold, high bluff, and readily known. Cano island is the best mark for the anchorage. It is bold, and can not be mistaken; when abeam it resembles a haystack.

After this comes Herradura point, and then Sucia point. 
Having passed Cano island and hauled up as directed, run until the light is seen, which will be at a mean distance of 6 miles, or if it is not scen run for Calderas bluff and proceed as before.

In the dry season there will be many fires on the land; be careful not to mistake them for the light.

Tides.-The tides at Punta Arenas are regular. The flood sets NE. and north from cape Blanco, then NW. and at the anchorage west; the ebb runs in contrary direction. It is said that off Herradura point the flood sets over to the westward, probably $\mathrm{NW}$, while on the western shore it sets into the land. Strong tide-rips off Sail rock will be found. Always calculate the time of high water at Punta Arenas when bound there, so as to know the set in going up the gulf.

When coasting along from Calderas bluff in 5 or 6 fathoms of water, and no lights are seen, be careful not to pass the lighthouse, as there is danger of running on the shoal. Pass Cano island $2 \frac{1}{2}$ miles distant, and when Herradura is abeam steer N. $16^{\circ} \mathrm{W}$. (N.22 $2^{\circ} \mathrm{W}$. mag.).

When in doubt anchor and await daylight.

Coast.-From Judas point the coast trends about E. by S. for nearly 23 miles to the Viejo river and then southfor 2 miles to Quepos point. The land immediately back of the beach is low, and the ascent towards the mountains in the interior, for the first few miles, is gradual. Vessels can anchor anywhere as there are no dangers over $\frac{1}{2}$ mile from the shore; and the soundings diminish regularly.

Quepos point, bold and prominent, at the western end of a line of densely wonded bluffs, rises abruptly from the shore to the eastward. Near the point and to the northward of it are a number of outlying rocks.

Quepos group, with the exception of one wooded island east of Naranjo point, consists of a chain of bare, detached rocks. No hidden dangers were found in the vicinity, but it would be prudent to keep more than $\frac{1}{2}$ mile to the southward when passing. Should the land hereabouts be sighted in thick weather the rock to the southward of Naranjo point can easily be recognized, as much of its surface is of a reddish color.

Coast.-From Naranjo point the coast trends about SE. by E. for nearly 25 miles to Uvita point. Dominical point, $6 \frac{1}{2}$ miles northwestward of Uvita, is easily distinguished by its dark color. A reef extends southeastward from this point for over a mile, but is close to shore. About half way between Dominical and Uvita points and $1 \frac{3}{4}$ miles off shore is an islet and $\frac{1}{2}$ mile south of this islet is a rock awash and about the same distance off shore.

Uvita bay.-Southwest of Uvita point, and connected with it by a sand spit that uncovers at half tide, is a small circular island, also called Uvita, from which the rocky reefs make out, one in a westerly and the other in a southeasterly direction, the whole resembling in form the letter $\mathrm{Y}$. 
Behind the hook formed by the point, the sand spit and the southeastern arm of the reef, is Uvita bay, and as the coast a few miles below sweeps around to the southward it affords a tolerably secure anchorage during all winds.

There are two or three huts on this island that can be distinguished several iniles, and as there are no others near the shores of the bay they serve to mark the anchorage and the position of the reefs.

From Uvita point the sand beach, with a strip of low land to the mountains, curves around 2 miles to the southward and eastward ending at the foot of the bluff. Fresh water can be obtained from two small streams that enter the bay near the anchorage; the one farther from the point flows, from a pool 10 to 12 feet deep, where casks can easily be filled and rolled across the beach.

Ballena island, a mass of whitish rock, shows distinctly against the wnoded slope of the mountain behind it, being often mistaken at a distance for a cliff or hillside left bare by a land slip. Coming from the southward or southward and westward three points of equal elevation will be seen, while from the westward there are only two. The Ballenitas are three pointed rocks near the shore and one mile east of Ballena. There are many sunken rocks in this vicinity.

Coast.-From Mala point, southward of Uvita bay, the coast bends in to the eastward for a mile, then turns sharply south for 15 miles to Guajamal bay, whence it again bends sharply to the westward to Violin point. All this coast is low, well wooded, and in this distance are several rivers.

Sacate islands, 3 miles northward of Violin point, are two flat rocks so close together that they generally appear as one. It would be prudent to keep a mile to the westward of a line between them and the Violin islands.

Guajamal bay, above Violin point, is shoal, and the low eoast north of it must be approached with caution, especially off the river mouths, as the soundings diminish suddenly inside of 15 fathoms.

Violin point, which is steep and rugged, has several small wooded islands so close under it that they can only be made out clearly when approached along the coast. They are known as the Violin islands.

Sierpe bay, south of Violin point, is a small, shallow inlet.

Coast.-From Violin point the coast trends suuth for $5 \frac{1}{2}$ miles, thence bends sharply to the west for 3 miles to San José point. At the head of the bight thus formed the Aguja river empties. It is said that it can be entered by boats and is the only place on the coast between the gulfs of Nicoya and Dulce where water can be obtained with facility. San José is a bluff headland with deep water at a moderate distance from the rocks at its base. San Pedro, the next point, is a cliffy projection having rocks 
abont it under water. Between these points and nearly a mile off shore is Lowrock reef.

The coast between San Pedro and Llorena points is bordered by a rocky reef, along which a number of islets rise, the largest called San Pedro rock, and another, close to it, being marked by trees that resemble umbrellas. At the upper end of the reef only low, black rocks are visible, but near Llorena point the islets are high and wooded, like the bluffs from which they have evidently been detached. The tace of the reef is comparatively clean, and vessels will avoid all danger by keeping a mile from the shore.

Llorena point, being at the termination of a well-wooded plain, can be easily distinguished over 15 miles; upon getting nearer a number of red patches on the face of the cliffs will be seen amongst the trees. One mile below the point there is a little waterfall, with a descent of nearly 100 feet.

Cano island lies about 10 miles off this part of the coast. It is covered with trees, rises on all sides with a steep ascent, and the surface of the island is so level that the tree tops present, from a distance, the appearance of almost an horizontal line. It is surrounded by rocks which extend from its western side for upwards of $\frac{1}{2}$ mile. From the NE. and SE. points reefs also extend out some distance. Outside the reefs the water deepens rapidly to 10 and 15 fathoms. The best water for anchoring is NE. of the island, but under no circumstances should a vessel go inside of 15 fathoms without sending a boat ahead.

Corcovado rock, midway between Llorena and Sal si puedes point and 2 miles off the mouth of the Sirena river, is dome-shaped and 60 feet high. No dangers were found outside of it, but from the nature of the bottom, as indicated by the pointed rocks to the southeastward, it would be prudent to keep a mile off in passing, or in not less than 12 fathoms. The shoals between it and Sal si puedes point will be cleared if, in running down the coast, the vessel is kept to the south ward of the range of Corcovado rock and Llorena point until you have Chanca Pelona rock of Sal si puedes point, bearing east, and, conversely, Chanca Pelona rock must be kept to the northward of east until the range of Corcovado rock and Llorena point is crossed. 'Losing the wind and drifting with the current, which sometimes sets to the northward and westward $1 \frac{1}{2}$. knots an hour, and, as the depth is not too great, it is best to anchor.

Sal si puedes point is high, and will be easily recognized from above or below by a natural terrace back of it. A reef, with rocks above water and awash, makes out from it 1,200 yards to the southward and westward.

Chanca Pelona is a circular, flat-topped rock, outside of which the soundings deepen in 2 miles from 10 to 120 fathoms.

Coast.- From Sal si puedes point the coast trends eastward and ESE. for a distance of 17 miles to Matapalo head. It is low and sandy and covered with trees all the way; immediately behind it is high land which 
can be seen for a considerable distance. The coast is generally steep to and at times there are very heavy breakers. .

Gulf of Dulce.-The gulf of Dulce extends into the land about 30 miles in a northwesterly direction. It is but little frequented and at present not more than 400 people inhabit its shores. It possesses numerous anchorages, and has no known dangers at a greater distance from the land than a mile, with the exception of the bank facing the Coto river; this is the principal danger in the gulf, but as the sea generally breaks upon it, there is but little difficulty in avoiding it.

The upper and larger portion of the gulf is a remarkable basin, with an average depth of 100 fathoms; therefore its navigation by sailing vessels, in the season of squalls and calms, must be attended with some risk.

Matapalo head, the western point of the entrance; is high, steep, and covered with trees. Under it and just off the extreme point is a conical rock that stands out prominently as the entrance is approached from the westward.

Matapalo rock is dark, and vessels must keep at least $\frac{1}{4}$ mile outside of it on account of the ledges near it and a sunken rock midway between it and the shore.

West coast.-All of the western shore of the gulf consists of a flat wellwooded country; sandy to Arenitas point and afterwards alluvial, Sombrero point has a reef extending from it for about $\frac{1}{2}$ mile and Tigrito point, 2 miles farther north, also has a reef extending $\frac{3}{4}$ mile.

Arenitas point is 10 miles inside of Matapalo head, but as the old chart represents the distance as nearly 16 miles, vessels using it must be careful not to mistake the sand bars at the mouth of the Tigre river for the beach.

Only two or three houses can be seen from below the point, and even after it is turned the village is not easily distinguished against the woods.

The anchorage above the point is between the mud flats in front of the village and the deep water to the northward, but SE. of the point and below the coral reef there is a broad shelf, on which the anchorage is also good.

Punta Arenitas.-Behind the point and just above the mouth of a small creek that enters from the southward is the village of Punta Arenitas, or San Domingo. The population of about 200 is made up of half-breeds, Indians, and negroes, but as this number is increased whenever political disturbances occur in the States of Chiriqui and Panama, the chance of obtaining fresh provisions is correspondingly diminished.

Supplies._Bullocks, poultry, and fish can generally be purchased at reasonable rates, but the wells are only sufficient to supply the inhabitants, and vessels short of water will have to send their boats 3 miles above the anchorage, to the Tigre river.

Directions.-Except in thick weather the anchorage can be easily found by the marks. on the opposite shore near Golfito. 
If iutending to anchor above the point run on, keeping over $\frac{1}{2}$ mile from the beach, and when you have the end of the spit bearing to the southward of S. $45^{\circ} \mathrm{W}$. (S. $39^{\circ} \mathrm{W}$. mag.) you will be past the upper end of the coral reef and can steer in for the anchorage in front of the village. The mud flats make out nearly 300 yards, and $\frac{1}{4}$ mile farther out the soundings are 20 and 25 fathoms; therefore the lead should be kept going and the anchor let go whenever a cast gives 12 or 15 fathoms.

Tigre point.-The Tigre river discharges here and boats can fill with fresh water from a small stream that joins nearly a mile above the mouth. El Rincon.-At $\frac{1}{3}$ mile from the head of the gulf, Isadora, a low point, covered with trees, projects $\frac{1}{2}$ mile from the southwestern shore; the little bay behind affords the only secure anchorage above Golfito. From the end of the point a sand spit runs out 200 yards, but while part of it is above high-water mark the depth is 20 fathoms just outside. El Rincon river flows into the bay here and at low tide the water is fresh nearly to the mouth. 'There are three or four huts on the northern and western shores with a little cleared land about them, but only bananas and plantains are raised. The bay is surrounded by the spurs of the sierra Sierpe.

As the shores gradually approach each other it is only necessary in making the anchorage to keep midway between them, and when the point and sand spit are made out, to round the latter at a safe distance.

El Rincon to the Esquinas river.-Bluffs of moderate elevation rise abruptly and the shore is indented by several small bays where the water is shoal enough in places to anchor, but vessels without a chart should not attempt feeling in with the lead, as some of the reefs have 50 fathoms close to their edges. The islets marked on the chart show distinctly against the bluffs and will assist in finding an anchorage. The valley of the Esquinas is a mile wide, and across the end are mud flats and sand bars that choke the several mouths of the river and make it difficult even for boats to enter.

San José is the name given to several cattle ranches that occupy the small patches of level ground between the bluffs just above San Juan point.

Golfito is a fine landlocked harbor opposite Punta Arenitas. The entrance, open to the southward and westward, leads into the northwestern end of the bay. On the peninsula, south of the entrnace, is a wooded hill 862 feet high, and, as the coast to the northward is high and abrupt, the entrance looks like a canyon or mountain pass. South of this hill the land is low and flat, and here the southeastern end of the bay is separated from the gulf by a narrow neck. Still farther south there is another hill, similar in appearance but more conspicuons to vessels coming up the gulf, as the coast below it is comparatively flat for several miles. Behind the bay is a steep ridge, with a conical eminence near the northwestern end, called Adams peak, 1,726 feet high. 
Three or four families live here, but nothing in the way of provisions can be obtained, and though several streams flow into the bay there is no place where a vessel can conveniently water.

Directions.-The coast below is bordered by a shoal that makes out from $\frac{1}{2}$ to $1 \frac{1}{2}$ miles, with from 20 to 50 fathons just outside; therefore a vessel rumning up the gulf should keep well off the shore until she has the entrance bearing N. $45^{\circ}$ E. (N. $39^{\circ}$ E. mag.). Steer in on that course, and when in the narrowest part, nearly ahead and against the woods beyond, a low island will be seen. It is covered with mangroves, and is connected with the sand beach on the starboard hand by a bar that uncovers at low water. When the island bears from SE. to SW. anchor. Soundings 6 to 7 fathoms, mud bottom. On the north side of the entrance the shore recedes, but a $2 \frac{1}{2}$-fathom shoal makes out from it and contracts the channel.

A vessel drawing over 15 feet, and not provided with the harbor chart, should wait for high water, or send a boat ahead to mark the end of the shoal on the north side of the channel. On account of the great depth of water outside the entrance, and the shoal coast to the southward, the lead can not be depended upon when the landmarks are obscured; therefore vessels should anchor above Banco point, and wait for clear weather.

Coto river.-The shoals at the mouth make out $1 \frac{1}{2}$, miles, and most of them uncover at low tide, leaving two narrow passages with less than $\frac{1}{2}$ fathom in them ; one along the northern shore, and the other leading across north a little to the left of a hut on Coto point. The sea generally breaks on the bar, and as sharks are numerous, the attempt to cross is attended with considerable danger. Outside the shoals the water deepens at once to 30 and 40 fathoms.

Pavon bay, inside of Banco point, there are soundings of from 3 to 5 fathoms at a mile from shore. Vessels may anchor here but only in fine weather and with the wind from the eastward.

Banco point, the eastern point of entrance to the gulf, is not very prominent, but as the entrance is neared it will be made out at the foot of the northwestern slope of Platanal head. There are a few detached rocks about it over which the surf breaks, and vessels passing should keep $\frac{1}{2}$ mile off, where they will have soundings in 9 and 10 fathoms.

Platanal head at a distance appears to mark the eastern side of the entrance.

Directions.-The gulf is in the projection of the coast between Llorena and Burica points, and navigators without observations for several days, and missing the entrance on either side for 30 miles, would know by the direction of the coast their position with respect to it. When in the offing the cerro Sal si puedes is the best mark, as it rises abruptly at Matapalo head and runs northwesterly 15 miles, gradually increasing in altitude. 
Rounding Burica point 25 miles to the southeastward of the entrance, Platanal point will easily be distinguished. Entering the gulf at night, the most convenient anchorage is in Pavon bay. Should it be blowing heavily from the SW., having run inside the heads 2 or 3 miles, you may steer about $\mathrm{N}$. $33^{\circ} \mathrm{W}$. (N. $39^{\circ} \mathrm{W}$. mag.) for an anchorage, as the lead will give you 10 and 12 fathoms over a mile from any danger. The report concerning the great depth of water along the western shore south of Tigrito point proves to have been incorrect. Running in from the westward at nightfall and being anxious to keep hold of the land, be careful not to mistake the rock just off the head for Matapalo rock.

Burica point is at the extremity of the peninsula SE. of the gulf of Dulce and marks the boundary between Costa Rica and Colombia. It has a group of hills back of it and looks like an island when first seen by vessels approaching along the land. Burica island is $\frac{1}{2}$ mile off the point and outside of the island are some rocks. The point should not be approached within the 20-fatthom line.

Tide.-In the vicinity of the point the flood tide sets NW. with some strength. 


\section{CHAPTER VIII.}

THE COAST OF COLOMBIA-BURICA POINT TO GARACHINE POINT, INCLUDING THE GULF OF PANAMA.

David bay.-Between Burica point and Parida island the coast, receding, forms a large bay, within which are no known dangers, and the shore on the east part consists of low islands, forming the delta of the David river. The principal entrance to the river is the boca San Pedro.

Anchorage.-Vessels may anchor outside the bar of David river in about 9 fathoms, distant about one mile from the breakers with the SE. point of San Pedro island bearing N. $6^{\circ}$ E. (north mag.). Vessels drawing up to 16 feet may cross the bar and enter the river.

Ciudad de David, the capital of the province of Chiriqui, has from 9,000 to 10,000 inhabitants, and is situated on the western branch of the David river, about 10 miles from the sea.

Supplies.-Meat, poultry, eggs, rice, yams, and fruit are in abundance and cheap. Good drinking water can be obtained from the river where it divides into the eastern and western branches.

Sevilla island abounds in game, which can be obtained with facility.

Parida island, of irregular shape, is well wooded, while rivulets afford an abundance of fresh water. The only commodious anchorage near Parida island is at its NE. end, under the protection of an island which affords shelter from southward in $6 \frac{1}{2}$ fathoms, mud bottom. If this anchorage be approached from seaward, steer for and pass Viuda rock, on the west side, at a distance of about $1 \frac{1}{2}$ miles, then direct the course for San José islands; leave these islands to the northward and steer for the north end of Parida island, keeping in from 7 to 8 fathoms, but decreasing to $3 \frac{1}{2}$ fathoms as the anchorage is approached; when it deepens again to $6 \frac{1}{2}$ fathoms anchor. At this end of Parida plenty of good water will be found. At the SW. end is a small bay called Chimmo; in it is from $2 \frac{1}{2}$ to 10 fathoms. In front of the bay is a small islet called Santa Cruz. The passage in is north of this islet. The lead should be kept going, and a good lookout for any sunken, rocks. Good water can be obtained here. The bay between Parida island and El Juco point, also known as Darid bay, has numerous islands (the largest Bolano), and among them many sunken reefs are scattered about on the east and $\mathrm{SE}$. sides to a distance from 3 to 4 miles, making the approach to this bay from SW. of some 
little risk. With the chart an anchorage can be selected without much difficulty.

Monitas islets._A About a mile SIV. from El Juco point are two islets named Monitas, connected together and surrounded by a reef, the southern of which has a close resemblance to a saddle.

Caution.-When sailing around the SW. point of Parida island it should be given a berth of about a mile on account of some sunken rocks $\frac{1}{2}$ mile from it, which have a depth of 15 and 16 fathoms close to then.

Viuda rock (the Widow).-At $2 \frac{3}{4}$ miles S. $11^{\circ} \mathrm{W}$. (S. $5^{\circ} \mathrm{W}$. mag.) from Monitas islets is an isolated rock named Viuda, having a reef extending from it about $\frac{1}{2}$ mile. As this reef and rock are both steep, with soundings of 10 to 12 fathoms close around, they require great care to avoid. It is said that to vessels approaching the bay, from southward, Viuda reef may be known by breakers; however, this is a very formidable danger.

Buey rock lies in the middle of the bay, and is a dangerous rock. It is only visible at half tide, and for which no well-defined landmarks can be given. Its extent is small, and the soundings close to it are 5 to 7 fathoms.

Channel.-The channel between Monitas islets and El Juco point is not considered safe, though the depth is 7 to 8 fathoms; hence vessels seeking anchorage steer for San José island and generally pass to the southward of these islands, between them and Viuda, or between the latter and the islets off the east side of Parida islands. Vessels can approach the islands within a moderate distance if ordinary precaution be taken to avoid undiscoverable dangers and anchor about midway between them and the Monitas.

San Lorenzo bay. - Vessels should avoid entering this bay, which is near El Juco point, as it is full of sunken rocks. There is a village a few miles up the San Lorenzo river.

Coast.-From Venado islands to Espartal island the coast is clear except the rocks off Red hill.

Pueblo Nuevo river.-The entrance is south of Espartal and Insolita islands and between them and Entrada point. The best time to enter the river is during the flood and with the wind from the seaward. The channel between the two large islands is shallow and can only be used by boats at high tide.

Provisions can be obtained at the village of Pueblo Nuevo.

Coast.-From Pueblo Nuevo to bahia Honda the coast is free a short distance off shore. The coast line is very irregular, and forms several bays, of which Pajaros, Rosario, and Monita are the principal ones, though all of them are exposed to winds from the westward.

Bahia Honda affords shelter from all winds and a berth can beselected in almost any part of it. The head of the bay is shallow, and when running in it is only necessary, to keep in mid-channel. The entrance does not 
stand out with sufficient prominence to be distinguished from a great distance, but a near approach brings it out distinctly.

Sentinela island forms the southern point of entrance. It is small, and rocks lie around it. A smaller islet, Cono, lies a short distance south of it, and both are separated by a narrow rocky channel from cape Jabali. Guarida point is the north point of entrance, nearly a mile northward of Sentinela, and the depth between is tolerably even, about 20 to 23 fathoms. This depth gradually decreases within the bay to 12 and 33 fathoms $1 \frac{1}{4}$ miles within the entrance up to Talon island, which is about 120 feet high.

Off the west point of Talon is Pueril a small island, and off its south point is another, Espuela. These separate bahia Honda into two anchorages, Chinche bay and Legamo bay. At 2 miles westward of the entrance is Medidor island, and off the south end of this is Pacora or Trucha, a small island, steep to on its southern side.

Directions.-In making bahia Honda, after having made out A fuera, in mid-channel off it, the islands of Medidor and Pacora will be seen. Pass south of Pacora and steer for Guarida point or more southward. When past this point bear up to port and make for the round wooded islet, Chinche, in the northwestern part of the bay, and anchor in from 11 to 14 fathoms, muddy bottom and well sheltered. Leaving bahia Honda is as easy as its access.

Water can be procured in great abundance, especially from a stream named Cobre. There is a watering place on the SE. side of the bay. A boat can anchor in calm weather and use a hose.

Anchorage.-The most convenient anchorage for large vessels is to the westward of Talon island, in Chinche bay. The only dangers in this vicinity are a sunken rock of 8 feet, 300 yards in length, northward of Guarida point, and a reef about the same distance northwestward from: Pueril island.

The Ladrones are two rocky and barren islands lying 14 miles S. $20^{\circ}$ W. (S. $14^{\circ} \mathrm{W}$. mag.) of the SW. point of Parida. They are steep to on the southern edge. The only known dangers are some rocks about a mile north of them, and a reef about 4 miles in the same direction, upon which at low tide is only 6 feet of water. As this reef is only shown by breakers when there is a stiff breeze, it must be carefully guarded against.

Montuosa is a smali, lofty, wooded island lying S. $25^{\circ}$ E. (S. $31^{\circ}$ E. mag.) 27 miles from the Ladrones. There are some rocks SE. of it, and a reef extends fully 3 miles to the northwestward. The bottom is rocky on the south and west sides. There is a beaclı of sand behind some little creeks that run in between the rocks, and here landing has been found.

Secas islands lie nearly on the meridian of $82^{\circ} \mathrm{W}$, at 14 miles off the coast. The group consist of three principal islands, with numerons 
rocks and islets, one of which is 5 miles northward of their southern edge. Among these islets and rocks are no known sunken dangers which are not indicated by breakers. Good shelter for small vessels can be found, and upon some of the islets a landing can be made. No fresh water is to be obtained.

La Bruja.-About 3 miles eastward from the Secas is a dangerous rock called La Bruja. The position of this reef makes it a formidable danger, especially at night.

Contreras.-This group, about 15 miles southeastward and 10 miles to the northward of Coiba, is composed of two principal islands, but has no good anchorage. Vessels can approach these islands without hesitation, as it is believed there are no sunken dangers which are not shown by breakers. About $1 \frac{1}{2}$ miles south of the islands is Prosper rock, a pimnacle bearing the appearance of a black tower. It is not prudent to pass between it and the islands on account of a reef midway in the channel, which is partially dry at low tide.

Afuera island is nearly midway between the north point of Coiba and the shore. It may be passed on either side, the only known danger around it being a reef from its SE. side, which has a black rock always uncovered at its outer edge, 400 yards from the shore. Afuerita islet nearly touches Afuera on the north.

Coiba or Quibo is the largest of the islands off this coast, and is 60 miles in circumference. It is covered with forests and there is abundance of water.

Vessels can anchor off all parts of it in fine weather, but it does not possess any bay or harbor in which vessels may be protected from all winds.

The western coast of Coiba is clear of danger, but there is a shoal extending a mile off its southern shore. Outside of this shoal about $2 \frac{1}{3}$ miles trom Racimo point is Hill rock, a dangerous shoal with 6 feet of water over it. There are several other rocks hereabouts, but they are above water. Hermosa point is the N W. extreme of the island, and east of it is the open bay of Hermosa. Baltasar head is the north extreme of the island.

Damas bay, on the eastern side of Coiba, is the principal anchorge. It is about $6 \frac{1}{2}$ miles wide and has a broad sandy flat at its head through which the rio San Juan flows. There is good anchorage in any part of the bay, the depths at $\frac{1}{4}$ mile from the flats being from 10 to 12 fathoms. The tide rises and falls about 6 feet. There is a narrow inlet between the reefs in the southern part of the bay, which might, with care, afford protection from the SE.

Rancheria or Quibito is a small island $1 \frac{1}{2}$ miles long, and $1 \frac{1}{2}$ miles off the NE. point of Coiba. To the SSE. of it there is anchorage sheltered by 
a round and high islet. Wood and water are easily procured. There are several other islands off this part of Coiba, but Rancheria is the largest.

There is a channel between Coiba and this island, but as there are several rocks in the passage it is not prudent to attempt it.

Hicaron, which lies off the SW. side of Coiba, is of triangular form, $3 \frac{3}{4}$ miles long, and well wooded. Its highest point, 830 feet high, is on the eastern side. David point is its northeastern extremity. Off Ursula the south point is Hicarita; a small islet, covered with cocoanut trees. The channel between these islands and Coiba is clear of sunken rocks, but as there are some dangers near the SE. point of Coiba, it will be better to pass to the southward of the Hicarons than to attempt this passage.

Montijo bay is half way between bahia Honda and Mariato point. It is an extensive bay, in front of which is the long, narrow island. of Cebaco, which nearly incloses it to the southward ; the channel to the westward of it is partly closed by Gobernador island. The bay is completely sheltered, but the depths inside are so irregular that it can be used only by vessels of light draft. The channel east of Cebaco shoals suddenly, and has some rocks in it. West of Cebaco the channel is divided by Gobernador island; the channel between the island and Brava point is preferable ; it is the widest, and in it the tidal stream is not so strong. Vessels should not proceed farther in than 4 fathoms, and it is necessary to be very careful with the lead on account of the steep banks which extend through the bay as far as Leones island.

Mariato point is about 27 miles SE. of Cebaco island and is bold and steep to. The coast between is low and in this distance several small rivers empty. Five miles NW. of the point is the small wooded island Naranjas, which has deep water outside. Mariato point is a good landfall for vessels from the westward bound to Panama; the southerly current setting. out of the gulf will be avoided by keeping under the land eastward of it.

Morro Puercos is 27 miles eastward of Mariato point. The coast between is clear except a reef above water 4 miles westward of morro Puercos. Two miles to eastward of the morro and $1 \frac{1}{8}$ miles off shore is another shoal which has 3 fathoms over it.

Coast.-From morro Puercos to Guanico point 7 miles to the north westward the coast bends in forming an open bight; it then bends again to the northward forming another and larger bight, in the eastern part of which is the Juera river, said to be navigable by large vessels and affording a supply of fresh water. Off the eastern point of this bight is a small island, Venade; eastward of this point about 12 miles is cape Mala.

Los Frailes are two remarkable rocks or islets, the southern one of which is $11 \frac{3}{4}$ miles S. $46^{\circ} \mathrm{W}$. (S. $40^{\circ} \mathrm{W}$. mag.) of cape Mala. They are $2 \frac{1}{4}$ miles apart and all steep-to with the exception of a reef extending 
about 200 yards from the NW. point of the southern rock. They are a good mark for approaching cape Mala.

The Gulf and Bay of Panama.-General Description.-By the isthmus of Panama is sometimes understood the whole neck of land between the continent of North and South America; generally the name is restricted to the narrow crossing from Panama to Colon or Aspinwall, the two other narrowest crossings being distinguished as the isthmus of San Blas (31 miles) and the isthmus of Darien (46 miles). Nearly the whole isthmus constitutes a State of the Confederation of Colombia, extending from the frontiers of Costa Rica to those of the State of Canca. Total population of Panama in 1881 was 285,000.

Cape Mala on the west and Garachiné point on the east may be taken as the limits of what is known as the Gulf of Panama. These points lie WSW. and ENE. 103 miles apart. The depth of the gulf within this line is about 80 miles, the city of Panama being at its head, and Panama bay is the space between the main and the Pearl islands.

Climate.-The geographical position of the isthmus of Panama, the absence of high mountains and the vast extent of forests and other uncultivated parts, tend to produce a hot and rainy climate, which, with the rexception of a few localities, as Chagres, Colon, Porto Cabello, is more - healthy and more favorable to Europeans than that of most tropical countries. Diseases of the digestive and integumentary systems are common, and malarial fevers, often of a most pernicious type, prevail throughout the year. The rainy season is the most unhealthy, especially at its end when the weather is changing. Yellow fever has prevailed at times in an epidemic form. On board ship, Panama is the most healthy place on the coast of Central America. Vessels of war have remained here many months at a time, their crews continuing in a healthy state.

The wet season commences in May and lasts till November. The rainfall gradually increases until it is fairly established in June, and continues through July, August and September, with strong southerly winds. In December the rains cease; the $\mathrm{NW}$. and $\mathrm{NNW}$., winds set in, producing an immediate change. During the dry season regular land and sea breezes blow. The sea breeze sets in about 10:30 a. m. from SSW., and generally increases in force until about 3:30 p. m., after which it gradually subsides and at sundown is quite calm.

About the end of June, the rains are regularly suspended for a short time. The average temperature of the year is very high.

Winds.-The navigation of the approaches to the gulf of Panama becomes to a sailing vessel one of the most tedious, uncertain, and vexatious undertakings known to the seaman. Between cape Corrientes and Panama the prevalent winds are from the northward and westward, with frequent :squalls from the SW. between the months of June and December. In 
the gulf of Panama the winds are regulated by the seasons; the prevalent wind is from the northward. In the fine season, commencing in December, the winds are regular and constant, bringing fine, dry weather. To the southward of the gulf they blow much harder, and off the coast of Veragua a double-reefed topsail breeze in January and February is not uncommon. In April and May the northerly winds are less regular and have more westings in them, with calms, light sea and land breezes, with occasional squalls from the southwestward. In June the rainy season sets in and the southerly winds become stronger, still the NW. wind occurs at times, and vessels sailing from Panama at all seasons will generally have a fair wind until south of cape Mala.

Between the Galápagos islands and the coast westward of the meridian of $80^{\circ} \mathrm{W}$. and south of the parallel of $5^{\circ} \mathrm{N}$., the winds are between south and west all the year round, and, except between the months of February and June, they are of sufficient strength and duration to make navigation easy; but northward of lat. $.5^{\circ} \mathrm{N}$. and between $80^{\circ} \mathrm{W}$. and $110^{\circ} \mathrm{W}$. is a region of calms and doldrums accompanied by rains and squalls.

Currents.-The gulf of Panama is subject to irregular currents, partly caused by the formation of the land and partly influenced by the Peruvian and Mexican streams, according to the varying strength of each. Malpelo island is surrounded by strong and rapid currents; these have been observed to set in opposite directions, sometimes to the NE. and sometimes to the SW. A steady current has been found to set to the northward after passing cape San Lorenzo, at the rate of 24 to 36 miles per day and extending off shore about 60 miles. This stream runs along the coast, following the direction of the land, enters and makes a complete circuit of the gulf and the bay of Panama, and then sets with considerable force, especially in the dry season, to the southward down the western side of the bay.

After passing cape Mala it meets the Mexican current from the WNW., causing tide rips, eddies, and the short choppy sea met with at the entrance to the gulf.

West coast.-Cape Mala, which forms the western point of entrance to the gulf of Panama, is a low but cliffy point with outlying rocky ledges, having deep water close to them. The land from the NW. slopes gradually down to the sea at this point from a considerable distance, making the exact cape difficult to distinguish, unless the breakers are seen. On opening the gulf around this cape a strong southerly set is generally experienced, especially in the dry season.

Iguana island, lying about 9 miles to the northward of cape Mala, is a little higher than the adjacent coast, and thus forms a conspicuous object. A ledge extends about 600 yards from its southern and also from its east- 
ern point, and in 1858 a reef was reported to stretch to the NNE. from its north point, but otherwise the island is steep to with 15 fathoms in the channel of about one mile in width between it and the main.

Parita bay, nearly 20 miles wide and open to the eastward, lies 38 miles NW. of cape Mala and 45 miles SW. of Chamé point. From the cape to Lisa point, on the suuth side of the bay, the shore is a hard bank with sandy beach in front; at the point mud flats are found and extend on the western side of Parita bay, the coast being a low mangrove shore, intersected by the mouths of no less than five small rivers; the land to the westward is also low, with several hummocks. The coast between the bay and Chamé point is a continuous beach, named playa Grande, in front of a low wooded bank. There is a depth of 4 and 5 fathoms about 2 miles off this beach, except S. $22^{\circ}$ E. (S. $27^{\circ}$ E. mag.) of the cerro Chamé, where there are only 4 fathoms nearly 7 miles from the land, the bank extending from that to Chamé point.

Tides.-The flood sets to the northward and the ebb to the SE., the latter being considerably the stronger, especially between the months of December and June.

Otoque and Bona islands, with Estiva and Redondo rosk, lying 6 miles southeastward of Chamé point, form a group similar but smaller than Taboga and Taboguilla, being cultivated and having a considerable village named La Goleta in the bay on the western side of Otoque. Otoquie and Bona are high and peaked and form good landmarks for vessels entering this side of the bay." Anchor in from 10 to 14 fathoms in any part of the group, as all dangers are above water.

Chamé bay, at the hear of which is a small river of the same name, is nearly filled up by large mud and sand banks. The largest is named Cabra Loma bank, lying in the middle, with Tabor island on it. Chamé point, the southern horn of the bay, is a singular, low, woody promontory jutting out into the sea. Between it and Cabra Loma bank is a convenient harbor, 2 miles. long by $\frac{3}{4}$ wide, with from 3 to 8 fathoms in it, and 16 to 18 feet close to the beach.

Coast.-The coast from Chamé point to Bruja point, a distance of 16 miles, forms a shoal bay, with several outlying banks and rocky islets, and vessels bound to Panama should keep near the island of Taboga and not approach the shore within the depth of 5 fathoms. Vique cove, in which there is a small village, is 5 miles westward from Bruja point. One mile to the NE. of Vique is a lofty treble-peaked hill, named cerro de Cabra, a conspicuous object for vessels bound to Panama, and is frequently mistaken for Taboga by those coming from the eastward.

Melones island, small and rocky, lies $2 \frac{1}{2}$ miles $\mathrm{NW}$. of Taboga, with a a rock above water, $\frac{1}{2}$ mile to the northward of it. 
Chamé island and Perique rock are of a similar nature and situated about the same distance southward of Taboga. Valladolid is a large rock nearly 2 miles to the SW. of Chamé island, with 8 and 10 fathoms close to.

Taboga island, with the islands of Urava and Taboguilla, is a small group lying south of Panama. Taboga, the highest and largest, is well cultivated, with a large village on its NE. side. To the north ward of the village is the morro of Taboga, a small hill connected with the mainland by a sandy neck covered at high water. This was formerly the headquarters of the Pacific Steam Navigation Company, which still have here some stores, a water tank with abundant supply of good water, and a gridiron 300 feet long.

The anchorage off the village is convenient, being about 600 yards from the shore in 10 fathoms.

Urava is a small lofty island separated from the SE. point of Taboga by a narrow and shoal channel; off its extreme is the small islet of Terapa.

Taboguilla, also well cultivated, with some islets off its SW. extreme, forms the NE. island of the group, with a wide and deep channel between it and Urava, in the center of which is a rock ; the sea seldom breaks over it at high water, and it must be carefully avoided by closing either island, both being steep-to, or vessels may pass south of it by keeping the neck of the Morro open, bearing N. $55^{\circ} \mathrm{W} .\left(\mathrm{N} .60^{\circ} \mathrm{W}\right.$. mag.). Farallon, a small islet, also lies in this channel, but it is steep-to, with 11 fathoms between it and Tuboguilla.

Panama road.-Guinea point is the northern extreme of a large, round, hilly projection which forms the western side of Panama road. Between this and the city of Panama are the mouths of the Farfan, San Juan, and rio Grande, small rivers with cultivated banks. The water on this side of the road is very shoal as far as Tortola and Tortolita. Changarmi island, surrounded by the Pulperia reefs, and the small islets of Cocovi and Cocoviceta are dangers mostly above water. This part of Panama bay should be avoided.

The shore between Panama and Petillo, a black, rocky promontory with a rocky leilge, forms a bay nearly $\frac{3}{4}$ mile deep, its head being mud, edged with a sandy beach ; a great portion of the bay is dry at low-water springs. It is termed "El Puerto" and it is here that most of the minor trade of the gulf is carried on by means of large canoes. 'These canoes, though of clumsy appearance, are well fitted for the navigation of the gulf and bring most of the tropical productions of the isthmus of Panama.

Buey point, only seen at half tide, forms the southern horn of this bay and the northeastern point of the long, rocky ledges that surround the eastern and southern shores of the peninsula of the city. These ledges extend 900 yards from the NE. bastion, 1,000 yards from the $11562-16$ 
SE. bastion in an easterly direction, and 500 yards in a southerly direction, forming a bay southward of Buey point on which is easy landing after half flood on the sandy bach. From the commencement of the suburbs, on the southern side, another ledge runs off for nearly $\frac{3}{4}$ mile, east of which are Los Hermanos, three black rocks visible at first quarter ebb. Detached rocks with 3 and 7 feet of water between them, visible only at low-water springs, lie off the SE. extreme of the rocks, the outer outer one being $6(00$ yards from the reef.

Naos, Perico, and Flamenco, and the outlying rock of San José, are a group of islands forming the south side of Panama road.

The passage between Perico and Flamenco is shoal and should not be used, but that between Flamenco and San José is deep and both islands steep to.

Naos is the headquarters of the Pacific Mail Steamship Company; the bay to the NE. forms a convenient anchorage. The isthmus on this side is sandy and steamers of 2,500 tons and upwards have been easily beached. beached. Large vessels drawing over 20 feet may coal at Perico. Coal is brought off in lighters. Vessels using the anchorage should, after passing Flamenco, keep close round the north end of Perico and anchor when the isthmus opens. Attention must be paid to the state of the tide. As before mentioned, fresh water, coal, and supplies from the mail company may be obtained here.

The dredging of the canal company has practically closed the channel west of Naos island and this has thrown the current down past Perico island. It is now practicable to go with large ships quite near the island and vessels drawing over 24 feet can anchor to the north and NNE. of Perico.

Danaide rocks.-These patches of conical rocks have only from 15 to 18 feet on them and $3 \frac{1}{2}$ and 4 fathoms on all sides. They lie awkwardly in the track of vessels standing in for the anchorage. This spot is a favorite fishing place and vessels should avoid canoes seen in its vicinity, as they are probably fishing on the rocks.

Sulphur rocks.-This dangerous reef, 1,200 yards long by 600 yards broad, has a rock awash in its center with 6 and 9 feet around it and outlying patches of 12 and 14 feet. The railroad flagstaff on with the center of Ancon bearing $\mathrm{N} .89^{\circ} \mathrm{W}$. (S. $86^{\circ} \mathrm{W}$. mag.) leads to the northward of the reef in 15 feet, but this passage should not be used at low-water springs. The Hermanos rocks, in line with a round peak over the rio Grande, leads to the anchorage in 18 feet.

The Knocker and Taboga rocks have only 6 feet of water on them. The Knocker lies nearly one mile S. $89^{\circ}$ E. (N. $86^{\circ}$ E. mag.) of the SE. bastion; the Taboga rock lies a little more than 400 yards to the SW. of 
the Knocker, with 16 feet of water between them and 12 feet inshore of them. No stranger should attempt to pass west of the buoy.

Directions.-Panama road, although shoal, may be considered secure; with good ground tackle and common precaution a vessel might lie there all the year round with one anchor down. The bottom being muddy holds well. Attention to the tides and soundings will enable a vessel to lie close in at times for discharge of cargo.

The inner anchorage is in 2 fathoms about a mile off shore; the outer anchorage is in $3 \frac{1}{2}$ to 4 fathoms about 2 miles off shore. Vessels drawing over 18 feet may round the Danaide rocks safely by keeping San José rock open of the west point of Taboga island bearing S. $32^{\circ} \mathrm{W}$. (S. $27^{\circ} \mathrm{W}$. mag.) until the cathedral towers are open to the eastward of mount Ancon. Having passed the Danaide rocks the ship will be fairly in the road and may anchor according to her draft. Hermanos rocks, visible at firstquarter ebb, in line with the hill between rio Grande and Farfan rivers, bearing S. $84^{\circ} \mathrm{W}$. (S. $79^{\circ} \mathrm{W}$. mag.), lead northward of Danaide rocks. Vessels drawing over 20 feet may anchor to the NE. of Perico.

Tides.-The flood tide usually sets to the northward and eastward, the abb to the southward and westward, and runs in strength according to the winds and seasons of the year from $\frac{1}{2}$ to $1 \frac{1}{2}$ knots per hour. The ebb is stronger than the flood. The long swell which occasionally sets into the road always ceases with the flowing tide. It has been remarked by the officers of the Pacific Mail Company that there is more rise in the small bay north of the town and also in their own anchorage than in the more open parts of the roadstead.

Panama, situated at the head of the bay, is the capital of the Department of Panama. It stands on a rocky peninsula, jutting out into the shallow water of the bay, and was formerly a strongly fortified city. It has a fine appearance from the sea, the churches, towns, and houses showing above the ruins of the fortifications, standing out from the dark hills inland and rendered still more conspicuous by mount Ancon, a hill nearly a mile to the westward.

Health and Hospitals.-The highest and lowest temperature at the observatory on Naos island was $102^{\circ}$ and $66^{\circ}$ Fahr. The most sickly parts of the year are at the changes of the seasons. It is considered that the prevailing direction of the wind has some influence upon the sanitary state, that the $\mathrm{NW}$. winds are healthful and the SE. winds have a contrary effect. During the wet season the air is loaded with moisture, calms and light variable winds prevail, and it is very oppressive. The sanitary condition is bad. The people are generally careless as to sanitary precautions. Yellow fever, remittent, bilious, and pernicious fevers are endemic and yellow fever was considered epidemic in July, 1885. No reliable information can be obtained as to the mortality of the port. It has been re- 
ported as high as 40 per diem during the sickly season. The Foreign hospital, built and owned by the canal company, is located on the side of mount Ancon. It is well managed and clean. It has a capacity of 500 beds; cost of occupation, $\$ 2$, and $\$ 5$ per day for a separate room. A sanitarium on Taboga island is connected with the hospital.

The St. Thomas hospital, in the city, is subsidized by the Government. It is not well kept and is very dirty. Capacity, small ; cost of occupation, $\$ 1$ per day.

Population.-The population in 1892 was estimated by the Prefest at 15,000 .

Consuls.-The United States is represented by a consul-general ; Great Britain and France by consuls, and other nations by honorary consular officers.

Supplies.-All the regular steamship lines have their own stores. Few transient ships visit the port and the supplies in dealers' hands are limited. Fresh provisions can be purchased. Beef, 12 cents; vegetables are often scarce; bread, 5 cents per pound; artificial ice, $\$ 50$ a ton. All kinds of fruits are obtainable. Sand is obtained from Perico island. Good water can be obtained from the Pacific Mail Company at Flamenco island, or from the Pacific Steam Navigation at Taboga island. From this place it is brought alongside and pumped into the tanks by steam pumps. The cost is 2 cents per gallon. The water supply of the city is derived entirely from springs or wells in the suburbs and from the rainfall collected in the tanks of the city houses.

Coaling facilities.-The Pantma Railroad Company, Pacific Mail Steamship Company, and the Pacific Steam Navigation Company keep on hand large quantities of coal. Of the different kinds, Cumberland, Cardiff, Welsh, New Castle, and Australian coal can be obtained, though it is said the steamship companies will not part with any coal when it can be purchased elsewhere. The coal is delivered alongside, the lighters holding from 150 to 250 tons. The cost per ton is from $\$ 13$ to $\$ 17$.

Coal may be obtained directly from the ship or collier, which greatly lessens the danger of fever.

Telegraph and postal communication.-Panama is connected with South American and Central American ports by the Mexico, Central and South American cable, also by a land line to Colon and thence by cable to Jamaica and the West Indies. The line to the United States goes via City of Mexico and Galveston, Tex. Postal communication to the United States and Europe is by Pacific Mail and other steamers from Colon ; for Central America, Mexico, and San Francisco by the Pacific Mail steamers from l'anama, and for South American ports by steamers of Pacific Steam Navigation Company. Mails from the United States are irregular at times. 
Steamer lines.-There are five lines of steamers which make Panama their terminal point, viz: (1) The line from Panama to San Francisco, on the 9 th, 19 th, and 29 th of each month, calling at Central America and Mexican ports. (2) The line from Panama to Champerico twice a month, calling at way ports. These lines are owned and managed by the Pacific Mail Steamship Company. (3) The line from Panama to Guayaquil, twice a month, Pacific Steam Navigation Company. (4,5) The Pacific Steam Navigation Company and the South American Steamship Company's lines from Panama to Valparaiso and way ports alternate with each other, working a weekly service.

Lights.-A fixed red light is shown on end of railroad wharf and is visible 3 miles. A fixed white light on top of customhouse, visible 7 miles.

Exports, imports, and port duties.-The commerce and trade of Panama naturally divides itself into two branches, viz, that which is local and that which is in transit. The transit trade is also divided into two parts; that to and from the United States, and that to and from Europe.

From the best information the entire local trade of Panama with the United States for the year 1885 was, exports, $\$ 3,728,961$; imports, $\$ 4,263,519$.

The local exports are India rubber (growing scarcer), gold dust, hides, ivory nuts, manganese, shells, tobacco, cocobolo (a cabinet wood), tortoise shells, vanilla, whale oil, sarsaparilla, cocoanuts, and fruit.

From South America the bulk of the shipments consists of bark, cotton, cocoa, and rubber. From the Central American States, coffee, sugar, and indigo.

There is a captain of the port, and also a health officer. These officers board all incoming vessels. The quarantine station is near Tabogilla island. Pilots are not requirel. The police force is inefficient.

Panama is nominally a free port, but import duties are levied on tobacco in all its forms, salted or preserved meats, wines and spirits, ale, beer, ginger beer, cider, etc., salt. In shipping stores for naval vessels on the coast to the care of the Consul-general at Panama, it is absolutely necessary that they should be accompanied by complete invoices, stating contents of each package, the weight thereof, and the cost value.

Small parcels must also be accompanied by a statement of contents and value, addressed to the Consul-general or to the person to whose care they are consigned.

Docks and machine shop.-There are no docks at Panama, nor any Government docks near by. The Pacific Mail Steamship Company have a small machine shop on Naos island for repairing ressels of their line, and the Pacific Steam Navigation Company have one at Taboga island for 
the same purpose. The gridiron at Taboga is the only means of repairing vessels' hulls.

Landing.-The general landing place at high water is round Bully point, inside the NE. bastion, at the market place known as "the steps." Great care is required when landing at Panama in steamcutters or other heavy boats, which can only be effected at nearly high water. Boats should pass southward of the outer white beacon, and leave all the other beacons on the port hand when going in.

Official calls and salutes.-The only native authorites to be called upon are the president of the Department of Panama and the president of the Republic, who is seldom in Panama. There are no saluting facilities.

Panama ship canal._-The Panama shipcanal, to connect the Atlantic and and Pacific oceans, is under construction between Colon and Panama. On the Pacific slope it will descend the valley of the rio Grande and be continued seaward to the island of Perico. Total length is 54 miles. Work on the canal ceased in 1889 .

The Panama railway, from Panama on the Pacific to Colon on the Atlantic, is 47 miles long. Fare is $\$ 25$ in American gold.

East coast.-Garachine point is the eastern entrance point of the gulf of Panama. The laud over the point is lofty. About 3 miles SW. of the point is cape Escarpado, off which is an islet named Gajuala.

Garachine bay, lying to the $\mathrm{NE}$. of the point, is shoal, the shore being low mangrove land, forming the mouths of the Sambu river, with mud banks, extending 3 miles from the coast. Three mouths open into the bay; at the entrance to the western is pueblo de Garachiné, a small collection of huts. Between Garachiné and Patena points is a bank $5 \frac{1}{2}$ miles long with patches of 15 feet of water on it and 4 and 5 fathoms inside, and 4 miles N. $49^{\circ} \mathrm{W}$. (N. $54^{\circ} \mathrm{W}$. mag.) of the former point is a small patch of $4 \frac{1}{2}$ fathoms with 6 and 8 fathoms close to. Vessels may anchor close off these points in convenient depths.

San Miguel bay.-The entrance to this bay is $6 \frac{1}{2}$ miles wide between Lorenzo point on the north and Patena point on the south. Off Lorenzo point is Iguana island, and 3 miles to the northward the mouth of the Congo river. From Iguana island the bay expands, being nearly 11 miles across. At 7 miles to the NE. is Pierce point, a rocky projection on the north shore; the eastern side has plenty of water along it. Off Patena point, which is just separated from the main, there is no known danger; at $2 \frac{1}{2}$ miles inside this is Colorado point, bold and rocky with a conspicuous patch of reddish clay on its face, the coast between forming a bay. The land then for $1 \frac{1}{2}$ miles gradually gets lower to Hamilton point, when it falls back to the eastward and bends around again to the.north, forming a bay $3 \frac{1}{2}$ miles across, with low mangrove shores, having a village and anchorage in it. There are some ledges of rocks in this bay that do not 
always show; great caution is necessary in using it, and a boat shruld first be sent in to point out the deep water.

Buey bank.-Buey bank is an extensive shoal, drying in patches at low water, on which a heavy sea breaks. Its inner edge lies nearly $1 \frac{1}{2}$ miles SW. of Lorenzo point, but the passage between should not be used, as there are only 10 feet of water in it and generally a heavy swell. A spit with 12 feet of water extends $1 \frac{1}{2}$ miles off the SW. end of the bank, and as $4 \frac{1}{2}$ fathoms of water only are found 5 miles SW. of it, vessels should not stand in within that depth.

Marks.-Colorado point kept open of Patena point bearing N. $50^{\circ} \mathrm{E}$. (N. $45^{\circ}$ E. mag.) is a good mark to clear the Buey bank and also for running into San Miguel bay.

Washington island is small and densely covered with wood. It lies about a mile from the inner point of the bay just spoken of, with several islets and rocks in the intermediate space. The channel up San Miguel bay is between Washington and Jones islands, a conspicuous little rock covered with grass

Strain island is covered with trees and scrub, and surrounded by a ledge of roccks extending a short distance off it towards the channel, but connected by mud banks with two islands westward of it. At this point Barry rock, an islet covered with cacti, lying about 600 yards from the eastern shore, contracts the channel to one mile in width; apparently there is deep water all around this rock, but the passage on its western side being by far the widest, most direct, and sounded, should be used. The channel continues about the same breadth to Virago point. In working through do not go within a line drawn from one island to the other, and avoid Bains bluff, one mile to the southward of Virago point, where there is a dangerous ledge of rocks 600 yards from the shore.

Stanley island, a low wooded island, divides the channel into two passages, both leading into Darien harbor; the principal one, or boca Grande, being a continuation of San Miguel bay in a northerly direction past the west and north sides of Stanley island; and the other, or boca Chica, between its southern side and Virago point. The latter channel, although much shorter, is too narrow for a sailing vessel to use with safety on account of the rapid tide.

Boca Chica has two dangerous ledges of rock at its outer entrance, one on each side, the passage between them being barely 300 yards wide. The southern ledge lies nearly 200 yards west of Virago point and only shows at low water, spring tides. Trevan rock, on the north side of the entrance, uncovers at half tide, about 400 yards from the shore of Stanley island. Mary island, the northern of the group before mentioned, kept just midway between the summit and NW., extreme of Jorey island, 
bearing S. $50^{\circ} \mathrm{W}$. (S. $45^{\circ}$ E. mag.) is an excellent mark for clearing these dangers. If brought on with the summit the vessel will get on the northern ledge, and if open to the westward she will be on the western one; when past these rocks keep in mid-channel. A small edge runs out a short distance from the SE., point of Stanley island, having passed which the vessel will be in Darien harbor, and may anchor as convenient in 5 and 10 fathoms of water, sand, and mud. The boca Chica is not recommended unless used at slackwater, for during the strength of the tide it runs 6 or 7 knots, the eldies making the steering difficult.

Boca Grande, between the rocks outside the boca Chica and Milne island on the western shore, is one mile broad, and continues nearly the same width for $1 \frac{1}{2}$ miles between Stanley island and the shore. After passing the boca Chica steer N. $40^{\circ} \mathrm{W}$. (N. $45^{\circ} \mathrm{W}$. mag.) so as to shut in Mary island by Milne island, and do not approach Stanley island within 600 yards. Milne island, just touching the eastern end of the islands connected with Strain island, bearing S. $3^{\circ} \mathrm{W}$. (S. $2^{\circ}$ E. mag.), is a good mark for rumning, and if working, when north of Milne island, tack directly Mary island opens off it on the one side and when Edith island is shut in on the other. The navigable channel at this point is $\frac{3}{4}$ mile wide, and begins to turn to the eastward round the north end of Stanley island, narrowing to $\frac{1}{2}$ mile between Ray and Jeannette islands on the north, and a large flat rock nearly always uncovered, and a little wooded island about 200 yards off Stanley island on the south ; following the chan nel it bends back to the SE. and contintes of the same brealth between Ellen and Paley islands on the west and the mainland on the east, into Darien harbor.

Darien harbor extends from the boca Grande for 11 or 12 miles in a SE. direction as far as the village of Chupigana. It is formed by the junction of the Tuyra and Savanna rivers, and the depth of water in it from Paley island as far as the mouth of the Savanna is from 10 to $4 \frac{1}{2}$ fathoms, beyond which there is not more than 12 to 18 feet at low water springs. The shores of the harbor are one continuous line of mangrove, with densely wooded hills from 100 to 300 feet high a short distance in-. land.

Palma village appears to be situated on the best spot, and has an abundance of fresh water.

Anchorage. - The best place is in from 7 to 10 fathoms, off the village of Palma, one mile to the southward of Price point, at about 600 yards from the western shore.

Vaguila rock, showing at about half tide, lies off the mouth of the Savanna, east $1 \frac{3}{4}$ miles from Palma point, with a good channel between it and Graham point, the west point of entrance to the river. 
Produce.-All tropical produce of the western hemisphere can be grown. Mahogany can be had in abundance, also the palm and India-rubber tree. Maize, rice, sugar, coffee, cocoa, yams, and plantains grow almost wild.

Climate.- The climate has its rainy and dry seasons, the former, commencing in May and lasting till November, accompained by the winds peculiar to the gulf of Panama. The other six months of the year are fine. With common care the country is comparatively healthy.

Tuyra river enters Darien harbor near the village of Chupigana. The river is described as being navigable 6 miles beyond the town. The rise and fall of the tide is 15 feet.

Savanna river meets the Lara river a few miles from its source, where the bottom is level with the half tide. From this point the depth increases, 3 fathoms at low water, being found $3 \frac{1}{2}$ miles to the southward, and from thence to the mouth, a distance of 12 miles, the depth varies from 9 to 2 fathoms, over a soft, muddy bottom. The navigable entrance is nearly a mile wide between Graham point and Haydon bank, and the shoresare low mangrove land, skirted with hills from 200 to 300 feet high within 2 miles of the banks. The anchorage is in $3 \frac{1}{2}$ fathoms, one mile NE. of Graham point.

Tides.-The tides in the narrows of Darien harbor run strong, and great care should therefore be taken. Springs are said to rise 24 feet.

San Josá bank.-This dangerous shoal, in the center of which is Trollope rock, with only 2 feet of water on it, lies in the fairway of vessels bound to Panama from the southward. The bank has $3 \frac{1}{2}, 5$, and 6 fathoms close to the rock, and 7 and 8 fathoms on its outer edge; vessels should not approach it within the depth of 10 fathoms.

Marks.-The Trollope rock may be easily avoided, either by keeping on the main shore until Garachiné point bears to the southward of east, or by passing about 2 miles from Galera island, taking care of the shoal patch and rocks off its southern side.

Brava point forms, with Lorenzo point, the northern point of entrance to San Miguel bay. Both these points are edged with reefs and outlying rocks, on which the sea breaks with great violence. This fact, together with the proximity of the Buey bank, makes this part of the coast dangerous, and it should therefore be avoided even by small vessels.

Farallon Ingles is a small but high island lying at the edge of the shoal off the Buenaventura river; there are 12 and 15 feet of water on its western side. At 4 miles northward of the Farallon is Gorda point, bold and woody, with 4 fathoms close to ; there is less swell after passing this point.

The Pajaros are two small rocky islets, with 4 and 5 fathoms off their west sides, but only 12 feet between them and the shore. At these islets 
a shoal commences with 5 fathoms on its outer edge, which fronts the whole shore of Panama bay as far around to the westward as Chamé point.

Trinidad river has a low, rocky projection forming its south point of entrance. A 3 -fathom channel was found in this river extending $1 \frac{1}{2}$ miles from the point; beyond which it was not examined. The northern bank of the river is composed of mangroves, continuing along the coast as far as Panama. Shag rock lies north of the entrance.

Mangue and Majaguay islands are high, wooded islets on the southwestern edge of a mud flat which extends from the north bank of Trinidad river and dries at low water.

Chiman river is wide at the mouth, but shoal, being nearly dry at low water, with small channels for canoes. The entrance is well marked by the Mangue islet and the wooded bluffs on each side. On the eastern side, under a hill, is the small town of Chiman.

Pelado islet, directly off the mouth of the Chiman river, is flat, of small extent, and has no trees, but is covered with a coarse, prickly shrub. It is steep-to on all sides, and forms an excellent mark for vessels bound up the bay for Panama.

The coast between Pelado islet and Chepillo island, 31 miles to the $\mathrm{NW}$. is low river land with mangrove bushes. There are several small streams, the principal being the Hondo and Corutu rivers, but both are shoal at the entrance. The land north of these rivers is of some elevation. Column peak and Asses Ears, about 12 miles north of Chiman river, and Thumb peak, at the west extreme of the range, are conspicuous. Extensive mud banks, dry at low water, from 4 to 2 miles off the coast; outside these again the water is shoal for some distance, and vessels standing towards the main should tack in 9 fathoms.

Chepillo island lies off the mouth of the Chepo river, about 2 miles from the coast, and is one mile long by $\frac{1}{2}$ mile broad, very fertile, being low on the north side, and rising by a gentle ascent towards the south, over which is a remarkable tree that forms an excellent mark to vessels bound up the bay. The southern point may be approached to one mile, but the other sides are shoal, a reef running off its northern point in the direction of the river.

Chepo river comes from some distance in the interior, having its rise near the head of the Savanna river. The entrance to the westward of Chepillo island, through a 10 -foot channel, is about 600 yards broad.

At the west bank of this river the mud flat recommences, and continues to Petillo point, just to northward of Panama; a shoal bank lies in front of the flat, and vessels should not stand nearer than 6 fathoms between Chepillo island and Panama. 
The Pearl islands, also known by the name of Islas del Rey, Perlas islands, Islas del Istmo, and Islas del Colombia, form an archipelago on the eastern side of Panama bay, covering an area of about 450 square miles, and consisting of 16 islands and several rocks.

Rey island is the largest, San José, Pedro Gonzales, Casaya, Saboga, and Pacheca are of secondary, and the rest of minor importance. There are from thirty to forty fishing villages about these islands, containing over 2,000 inhabitants, chiefly engaged in the pearl fishery.

The pearl shells gathered at these islands are what are known as Panama or Bullock shells, and are shipped to San Francisco or Panama in barrels.

These islands are low and wooded, the soil fertile, but not much cultivated, and the numerous cocoanut groves and bright sandly beaches, intersected by small rocky bluffs, crowned with trees, give them a pleasant appearance.

Saboga anchorage.-Pacheca, Saboga, and Contulora islands form the northern part of the archipelago, and between them is a gool and spacious harbor, well suited as a depot for steamers.

On the eastern side of Saboga is a considerable village. Contadora has 5 fathoms close to its NW. shore, which is low and well adapted for wharves.

This harbor is nearly 2 miles long by one mile broad, has an average depth of 9 fathoms and three entrances, each possessing a 5 -fathom channel, which may be used as best suited to wind and tide.

All these channels should be used with caution as several shoal patches are reported, especially in the Saboga channel, and the soundings are changing.

Chapera and Pajaros.-There is a 4 -fathom channel between Chapera and Pajaros, but the ground is foul and it should not be used. No ressel should attempt the passage between these islands and Rey island.

Clearing marks.-The whole of the islands stretching to the northwestward, from the northwestern point of Rey island should be avoided by vessels bound up Panama bay, by approaching no nearer on their western side than just to open the eastern part of San José island eastward of Peciro Gonzales island, bearing S. $6^{\circ}$ E. (S. $11^{\circ}$ E. mag.), while on their eastern side they should not open San Pablo, a small islet off the NE. point of Rey island, or bring it to bear eastward of S. $31^{\circ}$ E. (S. $36^{\circ}$ E. mag).

Rey island is 15 miles long by 7 miles wide, with several peaks on it. Numerous islets, having deep water between them, lie 3 miles off its western shore, but they should not be approached by strangers within the depth of 10 fathoms. Cocos point, its southern extreme, is a remarkable promontory, jutting out into the sea, its extreme cliff being crowned by an umbrella tree, which makes it conspicuous. 
There are also islands off the eastern shore of Rey island, but they are steep-to and may be alpproached to within $\frac{1}{2}$ mile, with the exception of Canas islind, where there is a 3 -fathom patch lying outside a sunken rock ner rly $1 \frac{1}{2}$ miles from shore.

St. Elmo bay, on the east side Cocos point, has convenient anchorage in from 6 to 9 fathoms and a good stream of water at its head at Lemon point.

San Miguel, the principal town of these islands, is on the north side of Rey island. It is of some size, has a conspicuous church, but is badly situater, landing being difficult at low water. Supplies are uncertain and dear. Vessels having to lie off the town should run in between Caracoles and Canrejo, using caution, as the bottom is irregular and rocks abundant, and anchor in about 6 or 7 fathoms when the church is shut in behind Afuera, an islet lying off the town.

Galera island is generally the first land made by vessels bound to Panama, the channel between the island and Cocos point being used, which clears vessels off San José bank. The island is small, has a cliff on its southern side sloping down to the beach, on which is a remarkable umbrella tree.

Pedro Gonzales island is separated from the rocky islets off the west side of Rey island by a broad deep channel and has on its northern side two bays, protected from the north by the islands of Senora and Senorita. The bays named Perry and Magicienne were examined as to their capabilities for a depot for steamers, and although not so good nor so near Panama as the harbor south of Pacheca island, yet they still have some advantages. Trapiche island, which is connected with the shore of Gonzales island at low-water springs by a sandy neck, divides the two bays. A large stream of water runs into the sea on the western side of Magicienne bay. The bay is small and 'shoal, without the advantage of Perry bay, the eastern one, which runs back a mile. Senora and Senorita, including the shoal off their eastern side, lie nearly a mile to the northward of 'Trapiche island, with a 7 -fathom channel between them and steep-to on both sides. The tidal stream is not felt in the anchorage, but there is a considerable set off the island, the flood running to the northward, the ebb to the southward being generally the stronger.

San Josá island.-The summit of this island is a table land. Nearly 2 miles southeastward from Iguana point, its northern extreme, is a large waterfall flowing into the sea and forming an excellent watering place.

On the SE. side of the island is a deep bay, but as the swell sets in there with great violence it is not convenient for shipping. Off the southern point are a number of rocks of singular and fantastic shapes, lashed by a violent surf. The western shore is bold and cliffy with a small bay near the center. 
Passage rock.-This dangerous sunken rock, with 12 and 9 fathoms alongside of it, lies near the center of the channel between San José and Gonzales islands, which otherwise is deep and clear.

Passages.-Bound to Panama.-Vessels bound to Panama from the northward should make the island of Hicaron, which lies about 50 miles westward of Mariato point, and from this endeavor to keep under the land as far as cape Mala. If unable to do this they should push across for the opposite coast of the continent, where the current will be found in their favor, or, getting eastward of cape Mala, the safest plan is to shape a course for Galera island and to use the eastern passage. At the same time, if tempted up the gulf by a fair wind, vessels should endeavor to get on the western coast of the Pearl islands, which have the advantages hereafter explained.

The passage from the southward into the gulf of Panama is easily made during the greater part of the year by keeping about 60 miles from the coast north of Guayaquil, and after crossing the line shaping a course for Galera island, at the same time taking. care, especially in the dry season, to stand inshore with the first northerly wind. By so doing vessels will most probably lave the current in their favor along the coast, whereas by keeping the center or on the western side of the gulf a strong southerly set will be experienced. After making Galera and clearing the San José bank the navigation between the Pearl islands and the main is clear and easy, with the adrantage of being able to anchor should the wind fail or the tide be against the vessel. As a rule this passage should be taken, but with a strong southerly wind the navigator is tempted to run up the bay, in which case he should still keep on the western shore of the Pearl islands, where anchorage and less current will be found should the wind fail, an event always to be expected in these regions. Between Chirambira point and cape Corrientes the land is low and faced with shoals, caused by the numerous rivers which have their outlets on this part of the coast; but after passing cape Corrientes it may be approached pretty closely, except off Francisco Solano point, where some rocky shoal patches extend to seaward, as the coast in general is bold-to. Care, however, should be taken not to run into the calms caused by the high land, as it is difficult to get off into the lreeze again, and the swell sets inshore, where it frequently happens that no anchorage is to be found till close to the rocks.

In beating up the bay of Panama in the fine season the eastern passage, or that between the Pearl islands and the main, is to be preferred, as, with one exception, it is free from dangers. The water is smooth and a regular tide enables you to make more northing than it would be possible to do in nine cases out of ten against the strong current and short high sea, which at this season prevails in the center or western side. During the rainy 
season a straight course up the bay is preferable to entangling yourself with the islands, the current generally following the direction of the wind.

Bound from Panama. - The great difficulty, however, is the passage out or rather from Panama bay.

The best plan for all sailing vessels, whether bound north or south from Panama, is to push to the southward and gain the SE. trade; by so doing they will not only avoid the doldrums and vexatious winds, but will have the additional advantage of salubrious weather, with the sea at a temperature of $75^{\circ}$ instead of $85^{\circ}$ Fahrenheit.

The passage to the northward has been made by keeping close inshore after passing cape Mala and navigating by the land and sea breezes, but this should only be attempted by vessels that are well found and manned unless bound to the ports of Central America when it is their only route.

The passage to the westward during the rainy season is a most tedious affair ; calms, squalls, contrary winds and currents, a heavy swell, and extreme heat, as well as an atmosphere loaded with moisture and rain, are the daily accompaniments. It often occurs that 20 miles of westing are not made in a week, and it is only by the industrious use of every squall and slant of wind that the passage can be made.

The following directions, the best for sailing vessels, are by Lieut. Maury, U. S. Navy:

"From Panama bay a vessel should make the best of her way south until she gets between latitude $5^{\circ} \mathrm{N}$. and the equator; on this course let her endeavor to keep near the meridian of $80^{\circ} \mathrm{W}$, and from this make a SW. course, if the winds will allow. Should the wind be SW. stand to the southward, but if SSW. stand to the west, if a good working breeze; if the wind be light and baffling, with rain, the vessel may know that she is in the doldrums, the quickest way to avoid which is by getting to the southward.

From latitude $2^{\circ} \mathrm{N}$., between June and January, vessels may stand off from the coast to the westward and pass northward of the Galapagos islands, taking care to keep to the southward of $5^{\circ} \mathrm{N}$. As far as $85^{\circ} \mathrm{W}$. they will have south and SSW. winds; but after passing that meridian the wind will haul round to the southward, and ressels bound to the South Pacific may consider themselves fairly in the trade. Vessels bound northward, after passing meridian of $105^{\circ}$, may edge away for the Clipperton rock, after passing which they may push to the northward for the northern trade.

Between January and April it may be better to cross the line between the Galapagos islands and the coast before pushing to the westward. This may probably take a week, which outlay of time, however, is far preferable to encountering the rexatious weather met in that season north of the Galapagos.

In this route it must be remembered that southward of latitude $1^{\circ} \mathrm{N}$. the wind hauls to the eastward as the vessel leaves the coast, and in the meridian of $83^{\circ} \mathrm{W}$. it is frequently found eastward of south; but at the same time vessels in standing off before crossing the equator must take care to avoid being driven to the northward of that latitude. In fact, there are few passages in which so much depends on the skill and experience of the navigator as in leaving the gulf of Panama.

Vessels bound to the northward in the above season should keep south of the line until westward of $105^{\circ} \mathrm{W}$., when a course may be shaped for $10^{\circ} \mathrm{N}$. and $120^{\circ} \mathrm{W}$., in which track they will probably find the northern trade." 
The above difficulties will be easily avoided by steamers. They may at once proceed to the starting points mentioned before. The best plan will be to steam for the meridian of $85^{\circ}$ west on the equator, from which position a course may be shaped according to destination and season of the year. From that position the sails will be found to be as powerful as the engines. 



\section{INDEX.}

A.

Abajo island

Abreojos point

Abreojos point, anchorage......

Acajutla

Acajutla, anchorage, caution -..

Acajutla landing...............

Acajutla light

Acajutla, steamers

Acajutla, supplies

Acamana point

Acamana point,anchorage

Acapulco ............

Acapulco, anchorage ...........

Acapulco, caution

Acapulco, customhouse

Acapulco, directions

$-159,163$

Acapulco, dues, telegraph _..... 162

Acapulco, exports, imports .......

Acapulco, harbor

Acapulco, light

Acapulco, mail, repa

Acapulco, pilots..............

Acapulco, supplies

Acatenango volcano .............

Ackerman island............

Adams peak ..................

Adair bay

Afuera island

Afuera point.

Afuerita islet

Agiabampo

Agua Pepa peak

Agua Verde bay

Agua volcano

Aguja mount

Aguja point

Aguja river

Agujas village

Ahome

Ahome point 11562
Page.

213

18

19

193

193

193

193

193

193

164

164

160

162

163

163

162

160

160

162

162

161,162

189

215

230

92

236

6

236

112

118

57

189

27

67

227

222

112

112
Alamo _...............

Alamos peak _...

Alcatraz $---c_{-1}$

Algodones islands ............ 102

Algodones mountain ............ 101

Alijos rocks_._.

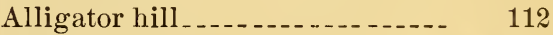

Almagre Chico .............. 105

Almagre Grande .............. 105

Almejas or Lee bay ......... $\quad 26$

Alotengo lagoon _............ 167

Altamura island............. 117

Altamura point ........ 117

Altata _...

Altata, anchorage ............ 118

Altata, estero _..._._. 118

Altata, railroad _...

Altata, steamers _..._. . _._._... 119

Altata, supplies _.............. 118

Amapala_._._._._._._._. 200

Amapala, anchorage _......... 200

Amapala, directions _..._...... 200

Amapala, port charges ........ $\quad 200$

Amapala, tides............ $\quad 200$

Amapala, supplies -......... 200

Amapala point _.......... 196

Amortajada bay .............. 53

Ancon -... 242

Angel de la Guardia island ..... 82

Angeles bay ................ 80

Angeles bay, directions ......... 81

Angeles bay, supplies .......... 81

Angeles port _.............. 174

Animas rock _...

Apisa river . . . . .

Aranca Barba point _............ . 210

Arboleda point............. 110

Arco cape_._.

Ardilla island ................ 105

Arena de la Velana point _._._._ 40 
Arena point

Arena point, anchorage .........

Arena point, caution

Arenas point

Arenilla point ..............

Arenitas point ........

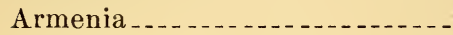

Arranco Cabello point

Arriba island ..................

Arroyo Blanco ..............

Arroyo de las Palmitas .........

Asadero estero ....................

Asserradores island

Asses Ears

Assoco volcano .

Asuncion bay

Asuncion island

Asuncion passage ...........

Asuncion point.

Atitlan volcano

Aves islands .

Ayres mount

Ayuca bay -

Ayuca river

Ayulta bar.

Azada island

\section{B.}

Bahia del Espiritu Santo _........

Bahia Honda -.................

Bahia Honda, anchorage .......

Bahia Honda, directions ........-

Bains bluff...-...............

Baja point ........................

Ballena bay ...........-...-.

Ballena head ...............

Ballena island ....................

Ballenas bay

Ballenas channel

Ballenas island ............

Ballenitas rocks .

Balsa river..................

Bamba bay

Banco point

Banda point

Banderas bay .

Baredito island

Bargo island

Barnabé rocks

Barnabe rocks, anchorage -...-

Baroyeca mountain
Page.
Barra Falsa channel

Page.

206

Barracas cape................ 71

Barracas table -........ 70

Barranca river ............ 223

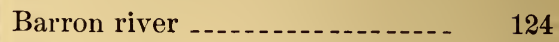

Barry rock

Bat islands .

Bay of Five Hills . . 7

Bayona river................ 125

Ben rock .

Bird rock _...

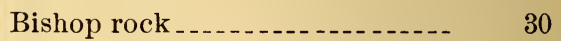

Black head ...... 150

Black point__._._._._._. 10

Black rock _._._. 55, 122, 141, 157, 171, 193

Black Rock point _._._._._._._._ 141

Black Warrior lagoon _._._._._. 11

Blanca bay ............... 9

Blanca island .............. 104, 220

Blanca point _._._._._._. 9

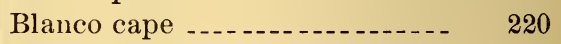

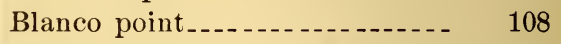

Blossom rock -........-..... 122

Bluff point _...

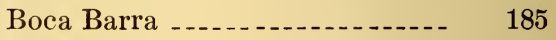

Boca Chica.... . . . . . . . 106, 160, 247

Boca de Comandu........... 22

Boca de la Purissima_._._..... 22

Boca de las Animas .......... 22

Boca de San Domingo .........- 22

Boca de Soledad ............. 22

Boca de Soledad, directions ....- $\quad 23$

Boca de Soledad, remarks......- 23

Boca de Soledad, wells. .......... 23

Boca del rio de Nexpa_......... 164

Boca Grande ........ 160,248

Boca Macapule _..._..._._._._. 116

Boca San Pedro ......... 233

Boca Tavala _._.

Boca Tecapan .............. 125

Boca Tecapan, anchorage....... $\quad 125$

Boca Trinidad _......... 40

Bolano island ............... 233

Bona island _...

Bonanza island ................ 44

Bonanza point ........... 50

Boundary monument .......... 1

Braithwaite bay _._._._._. 135

Brava point_..._._._._._._._. 237, 249

Braxilito bay -................ 217

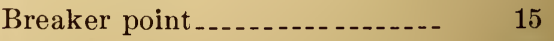

Brito .... -... 208 
Page.

Brothers point

144

Bruja point

160,240

Brumel islands

216

Bubosa island.

Buena point

Buenaventura river

Buena Vista mountain

Buey bank

Buey point

Buey rock

Bully point

Burica island

Burica point

Burica point, tide

Burra Grande reef

\section{C.}

Caballo island

Cabeza Ballena

Cabo Negro.

Cabra Loma bank

Cacaluta island

Cacaluta island, anchorage....--

Cacique point

Calamahue mountain ...........

Calderas bluff _..._..............

Calpica village _._._............

Camaron point

Camichen estero $-120,131$

Canas island

Candelero island

Candeleros point

Candeleros point, caution

Candeleros point, rocks

Cano island

Cano island (south)

Canoas point.

Cañon de Providencia

Cañon de Purgatorio .

Cañon de Santa Agueda

Cañon de Santa Rosalia

Canrejo island

Cantada island

Canuta

Cape Arco

Cape Barracas

Cape Blanco

Cape Colnett

Cape Corrientes

Cape Corrientes, current.

Cape Corrientes, danger, landing
205

216

249

188

247

241

234

246

232

232

232

205

221

36

10

240

173

173

216

6,88

222

155

126

252

103

58

58

59 221, 228

220
Cape Corso

Cape Desolado

Cape Elena

Cape Falso

Cape Haro

Cape Haro, light

Cape Henslow

Cape Jabli .

Cape Lobos

Cape Mala

Cape Middleton

Cape Natan.

Cape Pearce

Cape Pulmo

Cape Redondo

Cape Rule

Cape San Agustin

Cape San Lazaro

Cape San Lucas

Cape San Miguel

Cape San Quentin

Cape Tepoca

Cape Tepoca anch

Cape Tepopa...............

Cape Tortolo _..................

Cape Toseo _......................

Cape Velas -..................

Cape Virgenes ................

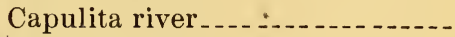

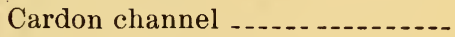

Cardon channel, caution .......-

Cardon head ...................

Cardon island .....................

Caracoles island

Carmen island

Carmen island, anchorage .....-

Carmen island, fish

Carmen island, port rules

Carmen island, salt pond.......

Carmen island, supplies ........

Carmen island, village ........

Carrera de los Viejos ..........

Carrizal bay ........................

Casparino point

Cassaya _...

Castanon bluff ................

Castanon shoal _..................

Castillo de la Entrada ..........

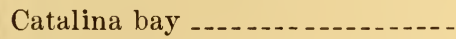

Catalina point.......

Cayo island ............................

Cayutlan lagoon
Page. 
Cebaco island

Page.

237

Cedro island

Center rock

Ceralbo channel

Ceralbo channel, caution

Ceralbo channel, directions

Ceralbo island

Cerro Bocochibampo

Cerro Chamé

Cerro Colorado

Cerro Compostella ..............

Cerro de Cabra...............

Cerro de Coacoyal..............

Cerro de la Ocote ...............

Cerro de la Playa ...............

Cerro de las Vigas .............

Cerro de Leon ..................

Cerro de Zadan .................

Cerro Grande de Turubales.....

Cerro Juluapan .................

Cerro Sal si puedes..............

Cerro Tordillo ...................

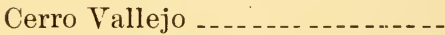

Cerro Yacicoris ...............

Cerros de Managua ............

Cerros de Piastla...............

Cerros de Sin Blas ............

Cerros Elena....................

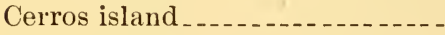

Cerros Prietos .................

Chacahua bay, anchorage .....-

Chacahua bay...................

Chacahua lagoon _..............

Chacala ensenada _..............

Chahuhe mountain............

Chamalta .....................

Chamalta hills ................

Chamalta river.................

Chamalta river, anchorage.....

Chame bay....................

Chame island

Chame point ..........-.

Chamela bay.................

Chamela point................

Chamela village...............

Chamela village, anchorage ....

Chamela village, directions .....

Chamela village, exports ......-

Chamela village, imports ......

Chamela village, supplięs ......

Chamela village, tonnage dues.-

Champerico
221

145

42

42

42

41

104

240

36

131

240

164

170

29

119

174

173

224

147

231

109

132

108

$20 \frac{4}{2}$

119

218

211

13

38

169

IER

$\pm \in E$

181

184

125

125

124

125

240

241

240

142

143

143

142

143

143

143

143

143

190
Champerico, anchorage.........

Champerico, currents ..........

Champerico, steamers _......

Champerico, tides ...........

Chanca Pelona rock ..........

Changarmi island ............

Chapala lake.................

Chapera island .............

Chapetona island ............

'Chepillo island...............

Chepo. river..................

Chester islets ....................

Chicarene point.............-

Chila river................ 131

Chillamo point__._._._._._._. 194

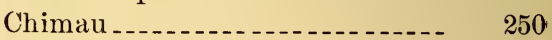

Chimau river._._. 250

Chimo point._..... 134

Chimo river................ 134

Chimmo bay ................ 233

Chinandega................. 207

Chinandega mountain........ 204

Chinche bay -................. 235

Chinche islet_............... 235

Chipequa bay ................ $177^{\circ}$

Chipequa bay, anchorage...... 177

Chipequa point ......... 176

Chiquito islet ............... 200

Chira island _................. 221

Chira island, anchorage........ 221

Chira river................... 221

Cholla islet ................ 62

Chubascos _._._._._._._._. 199

Chuenque bay _............ 59

Chupigana_................. 248

Ciaris estero _.............. 111

Ciaris island ............... 110

Ciervo island _................ 122

Cismuyo bay .................. 201

Ciudad de David .............. 233

Clarion island.............. 137

Clarion island, supplies........ 138

Clement island.............. 30

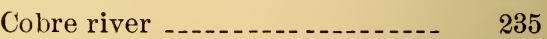

Cocina island ........... 142, 215

Cocos bay .............. 216

Cocos point

Cocovi islet ............ 241

Cocoviceta islet _......... 241

Coffin rock._._._._. 15

Coiba island _._._._._._._. 236

Coiba island, supplies _...... 236 
Colima

Page.

150

150

Colima volcano

Colnett bay

Colnett cape

Colorado island

Colorado peak

Colorado point $\_46,64,67,70,104,118,246$

Colorado river

Colorado river, beacons ...........

Colorado river, caution

Colorado river, currents

Colorado river, remarks

Column peak

Colville

Comandu mission

Conception bay

Conception point

Conchagua volcano

Conchaguita volcano

Condega -

Cone point

Cone rock

Conejo bay

Conejo bluff

Congo river.

Cono islet.

Consag rock

Contadora island

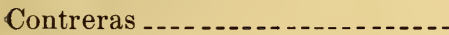

Conway reef ...................

Cooper island

Corcovado peak

Corcovado rock

Corrientes cape

Corrientes cape, current

Corinto

Corinto, exports, imports _...-.-

Corinto, harbor

Corinto, landmarks

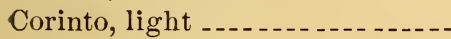

Corinto, supplies

Cornwallis bay

Coronodos island

Coronados island, anchorage..--

Coronados island, passage ......

Coronados islets

Coronados islets, anchorage ....

Corrales harbor

Corso cape

Cortez shoal

Corutu river

Corvetena rock.

90

91

91

91

250

91

22, 61

67

67

196

199

202

9

146

177

177

246

235

88

251

236

207

32

164

228

135

135

207

207

205

206

207

207

136

64

64

64

2
Coseguina point ...............

Coseguina volcano -.......-...-

Costa del Balsamo _.............

5 Costa Rica .....................

142 Costa Rica, landmarks ..........

70 Costa Rica, port charges ........

Coto river.

Cove, the -

Cove point.......................

Coyolate river

$\begin{array}{lr}\text { Coyote point } & \\ \text { Coyote rocks } \ldots \ldots & 52\end{array}$

Coyuquilla river _............ 159

Craig channel_..._._._._._._. 72

Cresciente island

Creston island ................ 121

Creston island, light_..._._._._. 121

Cuayacan bar._._._._... 187

Cucheritas rocks _._. 139

Culiacan _._.

Culiacan mountains _._._._._-_. 118

Culiacan river _._._. 118

Custodias river ............. 131

D.

Damas bay _...

Danaide rocks . .............. 242

Danzante island.............. 59

Darien harbor _._._._._._._._._. 248

Darien harbor, climate _........- $\quad 249$

Darien harbor, produce _..._._. $\quad 249$

Darien harbor, tides ............ $\quad 249$

Dark bluff _._.

Dark hill _......_.

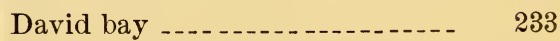

David bay, anchorage _._._._._. 233

David bay, supplies ........... 233

David point__._._._._._._._. 237

David river ................ 233

Del Marquiis point

Descanso bay _................ 2

Descanso point _............. 2

Descarte point_..._._._._._._. 212

Desolado cape ................ $20 \%$

Despensa island ............... 213

Dewey channel _............. 13

Diablo point _..._.

Diamante point ............ 162

Diggs point_..._._._._._._. 88

Direction sandhill _._._._._._. $\quad 89$

Dispensa point__._._._._._._. 51

Page.

204

204

194

211

211

211

231

135

25

191

68 
Disposicion island

Doble island

Doble point

Dolores bay

Dolores point

Dominical point

Double peak.

Dulce bay

Dulce gulf

Dulce river

Dulce river, supplies

Durango railroad

E.

East rock

Eastern harbor

Eastern harbor, directions .......

Edith island.....................

El Altar

El Cardonal

El Cochore

El Conejo point

El Cordonazo -................

El Cuello_.....................

El Dorado saddle

El Fuerte

El Infiernillo

El Juco point

El Limona _....................

El Mogote . . . . . . - . - . - .

El Morro _......................

El Morro Redondo ..............

El Mostrador ................

El Puerto..... . . .

El Recodo . .

El Rincon river ..............

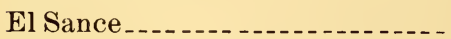

Elena bay -...-.-.-...........

Elena bay, directions...........-

Elena cape.........-.........

Elena port - . - . - . -

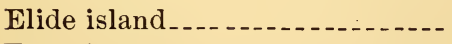

Ellen island .........

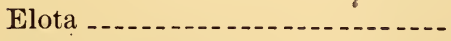

Elota river

Encomiedo point.

Ensenada

Ensenada, anchorage

Ensenada pilots

Ensenada point

Ensenada, port charges

Ensenada, steamers
Page.

200

102

102

55

55

226

82,118

164

229

164

164

119

193

84

85

248

94

50

108

27

34

121

118

112

97

233

42

47

160

13

42

241

166

230

61

212

213

214

213

10

248

119

119

169

3

3

3

3

3

3
Ensenada, supplies

Page.

Ensenada, telegraph

Ensenada Carisel ..............

Ensenada de Bocochibampo -..--

Ensenada de San Francisco .....-

Ensenada de las Tetas.

Ensenada Matenchen

Entrada point

Equipalto rock

Escarpado cape

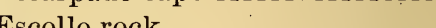

Escollo rock -.......-...-.

Escondido bay -.............

Escondido bay, landing -.....-.--

Escondido bay, supplies ........

Escondido bluffs

Escondido point

Espartal island .................

Espiritu Santo island .........-.-

Espuela island .................

Esquinas river ..................

Estero Cochore

Estero de Agiabampo...........

Estero de San Cristobal........-.

Estero de Santa Lugada ........-

Estero de Soldado ................

Estero de Tastiota..............

Estero de Tomates.............

Estero de la Luna ...............

Estero de la Paran .............

Estero de las Piedras...........

Estero del Rancho...............

Estero Donna Paula .............

Estero Palomina

Estero Real

- - - - - - - -

Estero Real, directions

Estiva rock

Estrella rock

Estrete island ..................

Eyre island

\section{F.}

Falsa bay -...

False bay -...

False Cardon ..................

False point

False point, reef ............

Falso cape...-. -

Farallon de San Ignacio........

Farallon Ingles ................

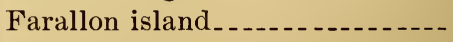

Farallon point ........-..-....

Farallon point, anchorage ......
3

3

104

103

103

102

131

$6,24,234$

69

246

221

170

170

170

169

169

234

43,50

235

230

108.

112

131

111

103

101

134

110

134

113

108

205

202

202

203

240

121

176

217

9

46

205

9

12

29

114

249

241

143

143 
Farallones Blancos ............

Farallones, the .................

Farfan river

Final point

Five hills

Flamenco island

Flat hill

Flat rock

Flat Top point

Fort lagoon

Frailes, the

Frigoli point

Fuego volcano

Fuerte

G.

Galera island

Gallina island

Gallina island, anchorage......-

Gallito point

Gallo island

Gallo island, anchorage .........

Gajuala islet.

Gama island

Garachiné bay

Garachiné point

Garova island

Gaspar rock

Gavelones point

Georges bar

Georges island

Gigante mountain

Gigante point

Gobernador island

Golfito

Golfito, directions

Gongora

Gorda point.

Gore island

Graham head

Graham point

Granite island

Grifo island

Grifo island, light

Grifo point

Grueza point

Guacalate river

Guadalajera

Guadelupe island

Guadelupe island, anchorage....

Guadelupe mission.
Page.

42

199

241

86

7

242

93

13

142

11

210

68

189

112

252

51

51

69

51

51

246

122

246

246

200

31

63

93

93

208

208

237

230

230

211

249

90

146

249

84

160

160

163

120

191

129

31

31

71
Guajamal bay ..................

Page.

Guanico point

227

237

Guapa island_.............. 69

Guapa rocks _............. 69

Guapinol point_............ 221

Guarida point_............... 235

Guatemala _................. 189

Guatemala, climate_.......... 189

Guatemala, dues.............. 189

Guatemala, exports_._._....... 189

Guatemala, seasons._._._._... 189

Guatemala la Nueva_........... 189

Guatulco harbor _.............. 173

Guatulco inner harbor......... 174

Guatulco river _..._._._._._. 173

Guaymas _._._._._._._._. 107

Guaymas, anchorage _.......... 106

Guaymas, climate _..._....... 107

Guaymas, directions _........ 106

Guaymas, exports _............ 107

Guaymas harbor _............ 105

Guaymas imports_..._....... 107

Guaymas, mails _..._._._._. 108

Guaymas, railroad _..._........ 107

Guaymas, steamers _.......... 107

Guaymas, supplies _........... $\quad \mathbf{1 0 7}$

Gueguenton mountain.......... 143

Guinea point_.............. 241

Guichicovi mountain _......... 184

Guionos point _._._._. 199,219

Guionos point, current _._._._. 199

Gulf of California _........... 33

Gulf of California, currents _... $\quad 34$

Gulf of California, fish _....... $\quad 35$

Gulf of California, red water.-.- 35

Gulf of California, weather _..._ $\quad 33$

Gulf of California, winds _..... 33

Gulf of Dulce..._._._._._._. 229

Gulf of Dulce, directions _..... $\quad 231$

Gulf of Fonseca_._._._._. 199

Gulf of Fonseca, currents_..._. $\quad 199$

Gulf of Fonseca, remarks...... 198

Gulf of Isadora _._._._.... $\quad 230$

Gulf of Nicoya_............. 220

Gulf of Nicoya, directions _.... $\quad 225$

Gulf of Nicoya, tides _......... $\quad 226$

Gulf of Papagayo _._._._._._. 218

Gulf of Tehuantepec _......... 181

Gulf of Tehuantepec, directions_ $\quad 181$

Gulf of Tehuantepec, currents - $\quad 180$

Gulf of Tehuantepec, winds _..._. 182, 183

Gull rock.................. 66 
H.

\begin{tabular}{r|l} 
Page. & Istapa \\
246 & Istapa bay \\
146 & Istapa bay, anchorage \\
146 & Istapa bay, island \\
104 & Istapa peninsula \\
5 & Islas del Colombia \\
175 & Islas del Istmo \\
222 & Islas del Rey \\
& Ixbue mountain
\end{tabular}

Page. 192

156

156

156

156

251

251

251

188

Haydon bank .................

249

163

Heads of Acapulco ............

Heintzelmans point ...........

Henderson island

Henslow cape ...................

Hermano rocks .

Hermosa bay ................

Hermosa cone ...............

Hermosa point

Hicarita islet ..................

Hermosillo _....................

Herradura mountains ..........

Herradura point and port.......

Hicaron island.......

Higeras bay .................

High bluff _.................

High Leaning peak ..........

Hill rock .......................

Huevo bay

Huevo islands ...................

Hondo river..................

Humbug bay ................

Hydrographic Office, agents of. -

Hydrographic Office, publications of . . . . . . . . .

\section{I.}

Icacos point

Iguana island 239,246

Ildefonso island

Ilo Pango lake.

Industrie rock

Insolita island

Isabel island

Isabel island, landing ...........

Isabel mount

Isadora gulf

Isalco volcano

Isla Grande bay ........

Isla Grande island

Isla Partida

Isla Raza

Islas Blancas.

\section{$\mathrm{J}$.}

Jabli cape.

235

Jalisco province:-_._._._._._. 92

Jaltemba bay _............. 131

Jaltepeque lagoon ............. 195

Japutica point _.............. 158

Jasper island ............... 220

Jiquilisco bay ................. 195

Jones island .... . . _ _._. 247

Jorey island ................ 247

Juanilla bay _._._._._._._._. 213

Juanilla island _.............. 213

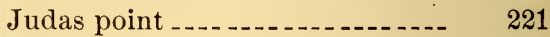

Judas reef _..... .

Juera river ................ 237

K.

Kellet channel_............. 13

Kelp point _.............. 14

Kino bay . . . 100

Kino point _........... 100

Knepper shoal _............. 19

Knob island . . . . 200

Knocker rock._._.

L.

Le Brea . . . .

La Bruja rock _.............. 236

La Cabeza de Cabello .......... 124

La Concordia -................ 195

La Cruz lăkgoon -.............. 100

La Giganta _................. 61

La Goleta................ 240

La Laguna . . . . . 108

La Libertad .................... 194

La Libertad, directions _........- 194

La Libertad, light _............... 194

La Libertad, steamers, telegraph_ $\quad 194$

La Libertad, supplies _..._. _..._. 194 
La Luz point

La Pasajera

La Paz

La Paz, anchorage

La Paz, boat channel

La Paz, climate

La Paz, commerce

La Paz, communication

La Paz, directions

La Paz, lights

La Paz, pilots

La Paz, port charges ...........

La Paz, quarantine

La Paz, supplies

La Paz, water

La Paz bay

La Paz bay, tides

La Paz channel

La Paz channel, directions

La Poza point

La Puerta

La Puerta, anchorage

La Tinaja . . . . . . . . . . . . .

La Tinaja point.

La Union .......................

La Union, directions .............

La Union, light ................

La Union, port ...................

La Union, supplies

La Union, tides

La Ventana

La Villa de los Castillos .........

Las Animas.....................

Las Animas bay.

Las Animas islets

Las Animas point

Las Galeras .......-..-

Las Mesas

Las Ornillas point

Las Piedras Blancas

Las Pilas volcano

Las Tetas de Cabra

Las Tres Marias

Las Tres Marietas

Las Ventanas

Las Virgenes

Ladrones

Lagoon head

Lara river

Lechuguia estero

Lechuguia island

Lee or Almejas bay
Page.
Legamo bay

Page.

Lemon point

23.)

Leones island

Lempa river

Lempa shoals

Lempa shoals, caution -..........

Lengua point

Leon -.-.-

Leon Viejo ...................

Light, Acajutla .................

Light, Acapulco _...............

Light, Cape Haro .............

Light, Corinto _.................

Light, Creston island ............

Light, La Libertad ..............

Light, La Paz.................

Light, La Union...............

Light, Mazatlan_..._._-_._._._.

Light, Nicoya gulf..............

Light, Ocos _..................

Light, Panama ...............

Light, San José de Guatemala _. -

Light, San Juan del Sur .........

Libertad

252

237

194

195

195

27

207

207

193

160

104

207

121

194

49

196

121

224

190

244

192

207

96

Libertad, anchorage -......... 95

Limon island.......... 205

Lisa point.....

List of H. O. agents _... _...... $\quad 282$

List of H. O. publications _...... $\quad 277$

Little Bat islands_............. 215

Little Bat islands, caution _..... $\quad 215$

Little Morro _ . _. _._. _._._. 167

Lizard point . . . .

Llorena point _...

Lorenzo point . .

Lobos cape . . .

Lobos island _..._. _ _ $45,104,110$

Lobos point ............ 28, 50, 62, 110

Lobos rock .............. 45, i2

Loma de Tigre _............... _ $20 \%$

Loreto

Loreto, anchorage.......... 60

Loreto, supplies_._._._._.

Los Arcos _...

Los Burros _........... 55

Los Cacachiles ..... . .

Los Candeleros ............. 58

Los Cordonazos -.... 34

Los Coronados .............. 2

Los Frailes _... _..._._. 29, 144, 148, 23 \%

Los Hermanos _.............. 242

Los Islotes............... 50 
Lowrock reef

Lower California, east coast_...- -

Lower California, east coast, currents

Lower California, east coast, remarks ......................

Lower California, east coast, weather

Lower California, e a st coast, winds

Lower California, west coast ....

Lower California, west coast, currents

Lower California, west coast, remarks

Lower California, west coast, weather, fogs .............

Lower California, west coast, winds .....................

Lupona point

M.

Macapule island .... . . . . . . . .

Madera mountain ..............

Madre Vieja river..............

Magdalena bay ................

Magdalena bay, anchorage .... -

Magdalena bay, landing -.......

Magdalena bay, remarks.........

Magdalena bay, settlement......

Magdalena bay, supplies .......

Magdalena bay, tides..........

Magdalena bay, water.........

Magdalena plains

Magicienne bay .

Mala cape ..................

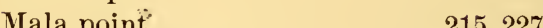

Maldonado bluffs ..............

Maldonado point .............. -

Maldonado point, tides, currents _

Managua -..................

Managua lake.............

Mangles point ................

Mangles point, anchorage -.....

Mangles point, caution .........

Mangrove point ............

Mangrove point, tides, currents -

Manguera island ............

Manguerita island .

Mangue island ..............

Manialtepec river

Manjagua island
Page,

228

33
Man of War cove.

Manuela lagoon.

Manzana

Manzanilla, the

Manzanilla bay -

Manzanilla point

Manzanillo

Manzanillo, anchorage

Manzanillo, currents, tide

Manzanillo, directions

Manzanillo, exports, imports...-

IIanzanillo, port charges.......

Manzanillo, steamers..........

Manzanillo, supplies ...........

Marabios range ................

Marcy channel .

Iarcy channel, shoal

Marcy channel, shoal ............

Marguerite island .............

Maria Cleopha _...............

Maria Laxara island............

Maria Madre .................

Maria Magdalena

Maria point ...................

IIaria rock ................

Mariato point

Marquez bay

Maruata bay

Maruata bay, anchorage ........

Maruata bay, landing:

Maruata bay, supplies

Matapalo head

Matapalo rock

Mayo river.

Mary island

Mazatlan

Mazatlan, anchorage

Mazatlan, caution

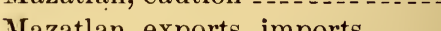

Mazatlan, exports, imports......

Mazatlan, harbor...........

Mazatlan, landing -.............

Mazatlan, lights.-......-....-.

Mazatlan, pilots, harbor dues...-

Mazatlan, steamers............

Mazatlan, supplies .............

Mechudo head ................

Mechudo mountain .............

Medidor island......................

Medio island ....................

Megia island ....................

Melones island .................

Mercenarios point.............

IIescal river ....................
Page.

25

11

205

162

147

148

149

148

149

148

149

149

149

149

204

26

27

201

129

31

130

130

9,105

12

237

61

152

152

152

152

229

229

101

247

123.

122

123

124

122

124

121

124

124

123 
Mesquite point

Metato peak

Mexico, coast of

Mexico, currents

Mexico, remarks

Michatoya river

Middleton cape

Miga point

Milne island

Mombacho mountain

Momotombo mountain

Moneypenny point ............

Monita bay ...................

Monitas islets

Monserrate island

Mońtague island

Montana rock

Monterey point

Monte Sella

Monte Verde

Montigo bay

Montuosa island

Monument point

Monument rock

Moreno rocks

Morro Ayuca

Morro Colorado

Morro de Papanoa

Morro de Petatlan

Morro de Potoci.

Morro de Salina Marques......

Morro de Salinas . ............

Morro de las Animas .........

Morro Hermoso _... . _ _..... 16, 169, 218

Morro Ingles...............

Morro Puercos

Morro Redondo point

Morro Tequepa ..............

Mount Agua

Mount Aguga........

Mount Ayres.

Mount Boughey

Mount Calamahue.

Mount Isabel

Mount Papayal

Mount San Carlos

Mount San Juan

Mount San Lazaro

Mount San Rafael

Muertos bay

Mulege .

Mulege, anchorage
Page.

104

124

92

92

92

192

136

216

248

204

204

204

234

234

58

90

42

132

122

110

237

235

85,98

138

55

175

101

158

157

158

178

178

158

105

237

13

158

118

27

13

219

6

25

209

114

128

37

104

40

70

70
Mulege, supplies

Murciellago bay

Murciellago bay, directions.....

Murciellago islands

Musimillama point

N.

Nagascol ….................

Nagascol hill _.................

Naguala river ..................

Naranjo point .................

Narisson point ..............

Natan cape .................

Natavidad bay . ..._._._._._.

Natividad island ..............

Navachista _.................

Navachista estero _...........

Navidad bay ....................

Navidad bay, anchorage -.......

Navidad bay, supplies ...........

Navidad head ...................

Negrita islet...........................

Negritas islands ................

Negritas island, caution ........

New island ......................

Nexpa village ................

Nicaragua -................

Nicaragua canal_._._.........

Nicaragua lake ...............

Nicaragua, port charges.......-

Nopolo point

North Hermano...........

North Viradores

Northers

Novilla islet

202

203

191

226

105

210

135

12

116

116

146

146

146

145

142

221

221

31

164

203

203

203

204

52,60

121

215

182

142

o.

Oaxaca _................

170

Oaxaca, road to ............. 170

Obispo rock

Ocos _..... 190

Ocos, anchorage....

Ocos, light _...

Ocos river.............. 190

Ojo Liebre, salt fields _......... 12

Ometepe mountain ............ $\quad 204$

Ometepes bay _............. 89

Oneal rock _...

Orosi peaks .................. 211

Oto bay ............... 62

Otoque island ............... 240 
P.

Pacheca island

Pacora island.

Pachutla

Pajaros bay

Pajaros island.

Pajaros island, anchorage -.....-

Pajaros, the

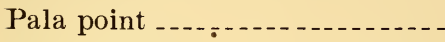

Paley island.

Palma point

Palma village

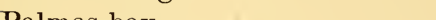

Palmas bay ...................

Palmia point.

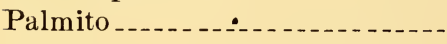

Panama -................

Panama bay -...-...-...-...-

Panama canal

Panama, climate -.............

Panama; consuls .....-.-.-...-

Panama, directions -............

Panama, docks...............

Panama, exports -.............

Panama, hospitals .............

Panama, landing .

Panama, passages

Panama, population

Panama, port dues.

Panama railway.

Panama road ................

Panama, steamers

Panama, supplies

Panama, telegraph

Panama, tides.

Panama, gulf of .

Panama, gulf of, climate.......-

Panama, gulf of, currents ......

Panama, gulf of, east coast _....-.

Panama, gulf of, passages ......

Panama, gulf of, tides.

Panama, gulf of, west coast

Pande A

Pande Azucar island -...-..-.-.-.

Papagayo, gulf of ............

Papagayo lagoon or river.......

Papagayos _............... 198, 218

Paps, the

Paps of Coyuca

Paps of Maruata.

Paps of Tegupan

Paredones point ...............

Parida island

Parida island, caution
Page.

251

235

171

234

105,121

121

249

121

248

248

248

39

36

125

243

241

246

238

244

243

245

245

248

246

253

244

245

246

241

245

244

244

243

238

238

239

246

252

240

238

221

218

163

29

159

153

153

103

233

234
Parita bay _... Page.

Partida island ...._._._. 78

Passarera island............ 142

Passage rock -...

Passion island................ 32

Patena point _._._. 246

Patos island _........ 96

Patos island, anchorage........ 997

Pavon bay _._..._._._._._. 231

Paxaros island ............. 31

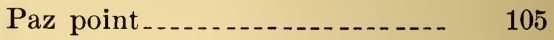

Pearce cape _..._._._._._._. 136

Pearl islands_..._._._._._._._. 251

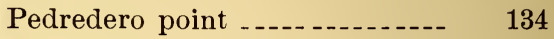

Pedro Gonzalez island _......... $\quad 252$

Pequeña bay ................. '21

Pelado islet................. 250

Pelican island._._._._._._._. 100

Pelican rock _............... 148

Pemta Scaco peninsula_._._._._. 206

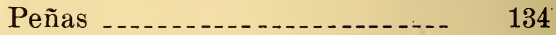

Peresil point _......_._._._._. 121

Peresil point, shoal _........... 121

Perez island ........ 200

Perico island ................ 242

Perico point _...

Perigallo island_.._..._._._. 199

Perique rock _._._._._._._. 241

Perlas islands _.............. 251

Perry bay _...

Perula bay _._. _._._._._._._. 142

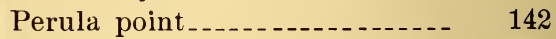

Petacalco bay

Petillo point _................ 241

Pescadores bay -............... 28

Pescadores point_............. 40

Phenomena _................ 18

Philips point _._. 90

Piastla _._._._. 120

Piastla point

Piastla point, anchorage _._._._. $\quad 120$

Piastla point, islet....-_-_-_._. 120

Piastla point, pier ............. 120

Piastla point, supplies _._._._._. 120

Piastla river.............. 120

Piedra Blanca _..._._._._147, 152, 169, 174

Piedra Blanca bay _............... 219

Piedra Blanca de Tierra.......- 127

Piedra Blanca del Mar..._._._._. 126

Piedra de la Marina_.._._._._._. $\quad 170$

Piedra Negra _.........._._._._. 215

Piedras Gordas.............. 42 
Pierce point

Pichilinque bay

Pichilinque bay, coal station....

Pichilinque bay, lighters.........

Pichilinque bay, water

Pichilinquillo bay

Pinacate mountain

Pinnacle rocks

Pitahaya island

Plantanal head

Playa Blanca bay

Playa Colorado

Playa Colorado estero

Playa de las Dolores.

Playa Grande

Playa Maria bay

Playa San Juan.

Point (see proper name)

Point of Rocks

Polfia point

Pond island

Pond island, anchorage.

Ponentè rock

Porfia point

Porpoise rock

Port Angeles

Port Angeles, anchorage

Port Angeles bay

Port Angeles, oil wells

Port Angeles, supplies

Port Caldera

Port Culebra

Port Culebra, directions

Port Elena

Port Herradura

Port Isabel

Port la Union

Port Marques.

Port Nagascolo

Port San Bartolomé.

Port San Bartoleme, anchorage. -

Port San Bartolomé, directions ..

Port San Quentin

Potrero

Potrero bay ....................

Potrero Grande bay

Prieta point

Primera Agua point

Prosper rock

Pueblo de Garachiné

Pueblo Nuevo .

Pueblo Nuevo river
Page.
Puerto Ballandra

Page.

Puerto Froond

Puerto Refugio _..._._.

Puerto San Benito _._._._._._. 187

Puerto San Carlos_... _._._._._. 103

Pueril island _................ 235

Pulmo cape _._._............ 38

Pulpito point

Pulpito point, anchorage

Punta Arena.................. 61

Punta Arenas................ 223

Punta Arenas, directions _.... . . . $\quad 224$

Punta Arenas, light, dues . ..... $\quad 224$

Punta Arenas, supplies......... 223

Punta Arenitas.............. 229

Punta Arenitas, directions . ... - 229

Punta Arenitas, supplies....... 229

Punta Baja_............. 61, 74, 105

Punta Blanca_._._._._._._._. 213

Punta Carrizal _..._._._._._. 147

Punta Chipequa_............. 176

Punta Coyote................. 59

Punta Coyote, water.......... 59

Punta de Campos............. 147

Punta de Papanoa............ 158

Punta de Santiago_............ 147

Punta de los Cuevas..._._._._. 103

Punta Escondido_........... 165

Punta Galera.................. 167

Punta Guela-gichi ............ 177

Punta los Custodias _.......... 131

Punta Mita_. _. . .

Punta Piedra Blanca_._._._._._. 134

Punta Raza_.................. 132

Punta Rosa_....._._-_._-_._-_ 111

Punta Sacate island.........-. 200

Punta Sicatela_._._._-_-_-__._ $\quad 170$

Punta Troncones_........_._._. 156

Purissima village

Q.

Quepos group............... 226

Quepos point_.............. 226

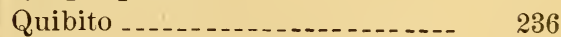

Quibo island

Quila_............... 119

Quinones point_._._..._...... 220

R.

Racimo point ............. 236

Ray island

Ranada point ................ 68 
Rancheria rocks ...............

Page.

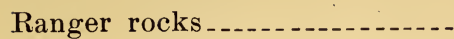

Raza island _.......................

Raza island, anchorage........

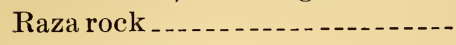

Realejo river

Red bluff _...........

Red Bluff point........

Red cone -...-..-.

Red hill ....-

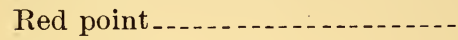

Red rock

Red water

Redondo cape................

Redondo rock

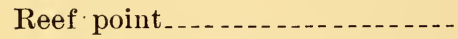

Reforma silver mine -.......-.

Rehusa channel................

Remedios bay....................

Remedios point............

Remedios point, caution_.....-

Remedios rock...............

Reported islands and shoals ....-

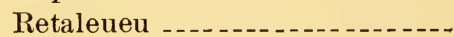

Revilla Gigedo islands _........

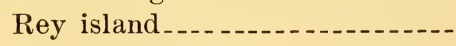

Ricason island....................

Rincon del Volcan Viejo......-.

Rincon river........

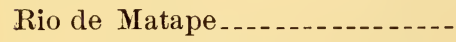

Rio de Santa Maria de Ahome.-

Rio de la Poza................

Rio del Fuerte...............

Rio del Valle..................

Rio Grande

Rio Grande de Lerma

Rio Grände de Santiago .........

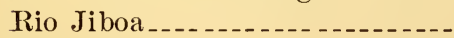

Rio la Paz........................

Rio Lempa..................

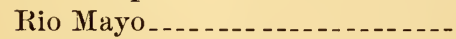

Rio Pascuales..................

Rio Piginto ..........................

Rio Real..............................

Rio Real, anchorage........

Rio San José......................

Rio San Juan

Rio San Lorenzo..............

Rio San Miguel.

Rio Santa Rosalia _.... _.........

Rio Sonora _..........

Rio Tavala

236

175

78

78

78

205

87

98

9

234

54,80

14

82, 193

193

193

30,138

190

135

251

68

211.

156

109

112

100

112

134

69,211

126

126

195

192

194

111

150

134

134

134

53

236

119

195

70

100

119
Rio Tecogame

Rio Verde........................

Rivas

Rivas point.

Road to Oaxaca.............

Robinsons landing -

Page.

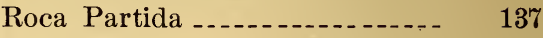

Rock point_._.

Rock point, anchorage .........-. 83

Rocky bluff -.-_-_-_-_-_._- 93

Rocky island -............. 80

Rocky point_......_._._._._10,93, 137

Rocky Point bay _. _. . . _ _._._. 93

Rodrigo rock

Roja point_-_._- 120

Roqueta island.............. 601

Rosalia point_._._._... 10

Rosario _..._._. 125

Rosario bay ................ 43, 234

Rosario bay, anchorage _....... 7

Rosario mission .............

Rota volcano_._............ 204

Round hill_._._._._._._.... 114

Round Top mountain_._._._... 81

Rugged peak

Rugged point_........... 136

Rule cape

Rush island _........ 214

\section{S.}

Saboga island..._.

Saboga, anchorage _..._._... 251

Sacate point _..._._._. 212

Sacate Grande island..._..... $\quad 200$

Sacate islands.............. 227

Sacate reef _... 200

Sacrificios bay _._._._._._. 172

Sacrificios bay, directions...... 173

Sacrificios bay, supplies _....... 173

Sacrificios island _._._._._. 173

Sacapulco bar._._._._. 186

Sacatula point._. 155

Sacatula river._._._._._._.-. 155

Sacatula river, anchorage_._._- 155

Sacramento reef _._._._._._._. 8

Sacua river _... 191

Safa volcano _...

Sail rock _............. 12, 85, 148, 221

Salada bay.................. 156

Salatea _._.

Saliaca island_._._._._..... 117

Salina Cruz_._._._._._._. 178 
Salina Cruz bay -...

Salina Cruz, landing

Salina Marques bay .............

Salinas bay

Salinas bay, directions ...........

Salinas island ...................

Salinas point

Salinas point, anchorage...-...-

Sal si Puedes channel ...........

Sal si Puedes island

Sal si Puedes point.

Salt pond

Samala river .....

Sambu river

San Andres islet

San Antonio

San Antonio point

San Augustine cape

San Augustine islet

San Bartolomé

San Basilio bay

San Basilio point.

San Benedicto island

San Benedicto island, landing -..

San Benedicto island, rocks .....

San Benito

San Benito islands

San Benito railroad

San Benito, supplies

San Bernadino hills

San Blas

San Blas, anchorage

San Blas, caution

San Blas, directions

San Blas, fevers

San Blas harbor

San Blas, landmarks

San Blas, remarks

San Blas, steamers

San Blas, supplies

San Bruno creek

San Bruno valley

San Carlos bay.

San Carlos point

San Cosme point

San Cosme rock

San Cristobal bay

San Cristobal point

San Damien rock

San Diego fort

San Diego island.

San Domingo point
Page.

178

179

178

63,211

212

212

54

54

77

77

2,228

62

191

246

142

41

7, 102

14

142

15

66

65

137

137

137

187

14

187

187

186

126

127

128

127,128

128

127

128

129

129

128

64

64

$55,75,155$

75

57

57

16

29

57

160

56

20,67
San Domingo point, anchorage. -

San Edwards point ..............

San Esteban island.............

San Eugenio point .............

San Evaristo head ...............

San Evaristo point...............

San Felipe........................

San Felipe bay ................

San Felipe point ................

San Fermin point ..............

San Francisco point............

San Francisco bar.............

San Francisco bay .............

San Francisco island ..........

San Francisco island, anchorage.

San Francisco village ...........

San Francisquito bay -.........

San Francisquito point .........

San Gabriel bay

San Gabriel bay, winds

San Gabriel point

San Geronimo

San Geronimo -...-...-.......

San Geronimo island ............

San Geronimo island, caution.-.

San Guillermo point............

San Hipolito bay -...-...-...-.

San Hipolito point

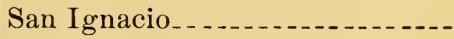

San Ignacio bay -.............

San Ignacio island .............

San Ignacio lagoon ............

San Ignacio lagoon, caution ....-

San Ignacio lagoon, products ...

San Ignacio point _..._._._._._20, 68, 113

San Ignacio river ............. 94

San Jacinto volcano _._. . . _. . . 204

San José _...

San José bank ............. 249

San José cañon _............

San José del Cabo_............. 37

San José del Cabo, anchorage _. $\quad 36$

San José del Cabo, bay ...-_...-. $\quad 36$

San José del Cabo, steamers -..- $\quad 36$

San Jose del Cabo, supplies..... 37

San Jose de Guaymas _-_._._._._ 108

San José de Guatemala _......... 191

San José de Guatemala, current, winds

191

San José de Guatemala, landing - 192

San José de Guatemala, light _.. 192

San José de Guatemala, mail telegraph ...........................

\section{0}

$18 \tilde{5}$

4
1 1 7

\section{6} 6 
San Jose de Guatemala, supplies $\quad \begin{array}{r}\text { Page. } \\ 191\end{array}$

San José point ................ 5, 227

San Jose island $215,233,252$

San José ranch................. 230

San José river 37

San José rock 243

San Jose valley

San Josef channel

San Josef island

San Juan

San Juan Bautista flats

San Juan Bautista point

San Juan de Dios bay

San Juan del Sur

San Juan, directions ...........

San Juan, light ................

San Juan, steamers.............

San Juan, supplies ............

San Juan, village .............

San Juan point .............

San Juan ranch ...............

San Juan river

San Juanico cove .............

San Juanico lagoon -...........

San Juanico point ..............

San Juanito island . .............

San Juanito island, caution .....-

San Juan Nepomucino island - - .

San Lazaro cape ..............

San Lazaro mount ..............

San Lino bay ................

San Lorenzo ................

San Lorenzo bay _..._. _. _._._._. 201, 234

San Lorenzo channel ...........

San Lorenzo channel, buoys -..-

San Lorenzo channel, directions.

San Lorenzo channel, winds ...-

San Lorenzo island ............

San Lorenzo island, landing ....

San Lorenzo point .............

San Lorenzo reef.

San Lorenzo river

San Lorenzo rocks

San Lucas cape

San Lucas bay, anchorage .....-

San Lucas bay, directions.

San Lucas bay, landing -........

.San Lucas cove ..............

San Lucas island.

San Lucas village
San Lucas village, supplies....-

San Luis .................. 191

San Luis island _...

San Luis river .... . .

San Luis Gonzales bay ......... $\quad 86$

San Marcial_................ 109

San Marcial point _............ 47

San Marcial rock _............. 57

San Marcos bar .............. 186

San Marcos island_............. 71

75 San Marcos island, anchorage _... 72

100 San Marcos island, remarks.... $\quad 72$

75 San Marcos island, water....... 72

156 San Marte bay .............. 56

208 San Martin island _........... 5

209 San Martin island, anchorage _.. 5

209 San Martin passage ............. 6

209 San Mateo .................. 184

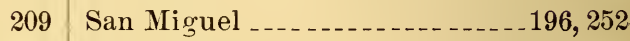

209 San Miguel bay _.... _......... 246

230 San Miguel cape _..._._._._._. $\quad 3,75$

49 San Miguel Chimalapa mountain 184

San Miguel point_._._._._._._. 99, 119

65 San Miguel volcano _........... 195

21 San Nicolas bay _............. 66

21 San Nicolas island............ 103

130 San Pablo bay _..._._._._._. 17

131 San Pablo islet _............... 251

45 San Pablo point ............... 16

23 San Pasquel point............. 57

37 San Pedro bay _............... 28, 101

67 San Pedro de Mistepec ......... $\quad 170$

201 San Pedro island _.............. 233

San Pedro islet................ 142

San Pedro Martin island ....... $\quad 76$

44 San Pedro Nolasco island ....... 69, 101

44 San Pedro point ............_28, 101, 227

44 San Pedro rock ............... 228

77 San Quentin bay ............. 7

77 San Quentin bay, caution ....... 7

45 San Quentin cape ............. 7

44 San Quentin port.............. 6

234 San Rafael bay _._._.

160 San Rafael point _......._._._. 104

29 San Ramon bay ............. 5

30 San Roque bay ............. 17

30 San Roque island ............. 17

30 San Roque point ............ 17

30 San Rosario

72 San Salvador

221 San Salvador city _._. _........ 192

30 . San Salvador, port charges ....- 192 
Page.

194

San Salvador volcano

San Selastian mines.

San Simon bar

San Telmo point

San Tomas bay.

San Vicente island

San Vicente volcano

San Vincente mission

San . Ysidro river

Santa Agueda point

Santa Agueda cañon

Santa Ana bay

Santa Ana lay, anchorage ......

Santa Ana creek

Santa Alla point

Santa Antonita point

Santa Barbara bay

Santa Catalina island.

Santa Catalina islands

Santa Catalina mission

Santa Catalina mountain........

Santa Clar’a teacon .............

Santa Clara mountain ..........

Santa Clara river..............

Santa Cruz _................

Santa Cruz bay

Santa Cruz island

Santa Cruz islet.

Santa Cruz point

Santa Cruzita point

Santa Inez bay

Santa Inez islands ..............

Santa Inez point

Santa Inez point, anchorage ...-

Santa Lucia bay

Santa Magdalena plains

Santa Margarita island .........

Santa Maria bay _..............

Santa Maria cañon

Santa Maria cove

Santa Maria del Marka

Santa Maria island

Santa Maria mountain

Santa Maria point

Santa Rosa mission

S.anta Rosalia bay

Santa Rosalia cañon _...........

Santa Rosalia de Moleje mission.

Santa Rosalia river .............

Santa Teresa bay.

Santa Teresa point

Santo Tomas 11562
123

187

56,151

213

105

194
Santo Tomas, anchorage

P'age.

Santo Tomas, directions

Santo Tomas point

Santo Tomas valley

Sand island

Sandy point

Santiago bay.

Sargents point

Savanna river

Sawyer lank

Sawyer bank, caution

Scammon lagoon _..............

Scammon lagoon, caution .......

Scout shoal

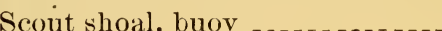

Seal rock

Seal rocks _.................

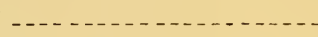

Sebastian Viscaino bay

Secas islands

Senora island

Semorita island

Sentinela island ...............

Serieuse shoal

Sesecapa

Sevilla island

Sextant point.

Shadani

Shag rock

138,250

Sharp peak .................. 2, 75,82

Shell point _.................. 114

Ship rock ................. 88

Shoal point _..._._._._. 89

Sicatela point _..._........... 170

Sicatela river ................ $\quad 170$

Sierpe bay _................. 227

Sierra de Navachista _... . . . . - 116

Sierra de San Lazaro _. . . . _.... 39

Sierra de San Pablo _........... 113

Sierra de San Sebastian_..._._._. 119

Sierra de la Giganta_........... 21,61

Sierra de la Victoria_._._._._._. 27, 36

Sierra Madre _..._._._._._._. 203

Sierra Pirtada _.............. 16.

Sierra Sierpe _..._._._._._._._. 230

Sierra Yaqui.................. 109

Sihuatanejo harbor._.......... 157

Sihuatanejo harbor, directions _. $\quad 157$

Sihuatanejo harbor, supplies_... $\quad 157$

Sinaloa _..._. _._._._._._._._. 92, 117

Sinaloa, railroad _._._......... 119

Sinaloa river .............. $117^{\circ}$

Sirena river................. 228

4

4

14

23

47

96

49

6

11

11

44

44

53
9

235

252

52

35

191

4

1

160

33

6

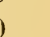

4

9

0

9


Six cañons

Six cañons, caution ..............

Smiths island .................

Smoke, remarks...............

Socorro island .................

Socorro island, remarks ..........

Soconusco bar.................

Soconusco bluffs .............

Soconusco volcano -......-...-

Soledad rocks ..................

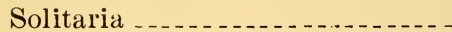

Solitary rock

S.ombrero peak

Sombrerito point

Sonora coast

Sonora, railroad

Sonora river

Sonsonale.

South bay.

South bluff -

South Hermano

South Viradores

Southeast point

Southwest hill

Speck reef

Sphynx islet

Split rock

Squall point

St. Elmo bay

Stanley island

Strain island

Suchiate bar ...............

Suchiate river

Sucia point

Sugarloaf peak

Sugarloaf rock

Sulphur bay

Sulphur rock

Sulphur rocks

Suwanee rocks

\section{T.}

Table mountain

Table peak -.....................

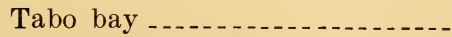

Tabo point........................

Taboga island

Taboga rocks

Taboguilla island
Paga:
Talor island .................

Tacana volcano ...............

Talon island ...............

Tamarinda bay _..............

Tamarinda river ............

Tambaliche roads............

Tampisco

Tampisco creek

Tangola Tangola bay ..........

Tangola Tangola island ........

Tangola Tangola island, supplies

Tapachula_...................-

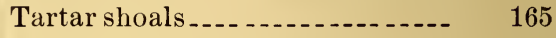

Tartar shoals, anchorage -.-.--.- 166

Tartar shoals, caution -...-_..-_ 165

Tartar shoals, current _._._._._._166, 172

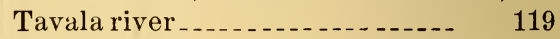

Tayuta river ................. 173

Tecoanape _._.

Tecojate_._.

Tecuani mountain

Tecusitan point

Tehuantepec city _._._._._._. 179

Tehuantepec gulf _..._._._._. 181

Tehuantepec gulf, currents _._._. 179, 180

Tehuantepec gulf, directions _.. 181

Tehuantepec gulf, northers _...-. 181

Tehuantepec gulf, remarks ..... 182

Tehuantepec gulf, winds _.......182, 183

Tehuantepec river............. 179

Tegojate _................. 191

Tegucigalpa_._.

Tejupan point_._._._._._._._._. 151

Tejupan point, caution _........ 151

Telica volcano _..._._._._._._._. 204

Tempisque river ............ 221

Tenacatita bay _._._._._._._. 144

Tenacatita bay, anchorage -...-. $\quad 145$

Tenacatita bay, supplies .......-. 145

Tenacatita bay, village _..._.... 145

Tepic_._._.

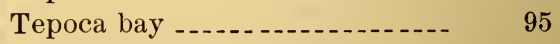

Tepoca bay, anchorage........ 95

Tepoca hill or cape _._._._._._. 94

Tepoca point

Tepopa cape................ 96

Tepopa peak

Tequepa bay _............ 158

Tequepa point _._._. 158

Terapa islet............... 241

Tetas de Cabra............. 102 
Thumb peak

Thurloe head

Tiburon island

Tiburon island, remarks ........

Tiburon island, west shore.

Tierra Firma point

Tigre island

Tigre mountain

Tigre point

Tigre river

Tigrito point

Tintorera point

Todos Santos

Todos Santos, anchorage------

Todos Santos bay

Todos Santos islan

Todos Santos river

Todos Santos valley

Tonala

Tonala, anchorage

Tonala bar

Tonala, landing

Tongulunda lagoon

Topolobampo

Topolobampo, anchorage ......

Topolobampo, bar............

Topolobampa, currents _........

Topolobampo, directions

Topolobampo harbor

Topolobampo, remarks _........

Tooth rock

Tortolita islet

Tortolo cape

Tortolo island

Tortuga island

Tortuga rock

Tosco cape

Tosco cape, anchorage

Trail to la $\mathrm{Paz}$

Trapiche island

Tres Picos

Trevan rock

Trinidad island

Trinidad point

Trinidad river

Triunfo mines

Trollope rock

Truncha island

Tule

Tule estero

Tule river

Turners island
Page.

250

16

97

99

99

64

200

200

230

230

229

62

27

28

3

185

185

185

185

184

114

114

114

115

114

114

115

213

241

16

241

73

121

26

26
Tututepec

Page.

Tututepec, supplies .............

168

Tíyra river

168

249

\section{U.}

Upper lagoon

11

Urava island .................. 241

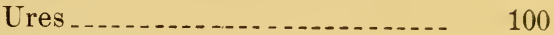

Ursula point ................ 23r

Uvita bay ................. 226

Uvita point ............... 227

V.

Vacamora - .... -

Vagares rock _............... 213

Vaguila rock ................. ¿48

Valladolid rock _..._.......... 241

Valle de Banderas bay _........ 133

Vegieco island ................. 221

Velas cape................... 218

Velasques island _............. 200

Venadi island................ 237

Venado island.............. 102, 121, 220

Ventana bay .................. 40

Ventana bay, anchorage _...... 41

Ventana point_............... 105

Ventosa bay _................ 179

Ventosa point_.............. 179

Viejo Mayo _.................. 111

Viejo river................. 226

Viejo volcano _._. _._._._._._._. 204

Viejo Yaqui _................... 109

Vigia Chica_.................. 148

Vigia Grande _................ 147

Vigia hill._................ 29

Vinorama island _............ 116

Violin island ............... $22 \%$

Violin point _............. 26 $22 \%$

Virago point _..._........... $24 \%$

Virgenes cape................

Vique cove ................. $\quad 240$

Virgin de Dolores mission ...... 55

Viradores, the _._._._._._._._. 216

Viuda rock -................. 234

Volcano of Colima _._._._._. 150

W.

Washington island .............

West bay .................... 144 
INDEX.

West harbor

Page.

West harbor, directions......... 85

Whale rock..................

White beacon -

White friars

White point

White rock

Widow, the

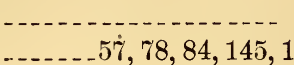

Willards bay

Willards point

Wreck cone.

Wright shoals

85

$\mathrm{Y}$.

19 Yaqui river

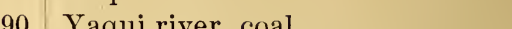

58 Yaqui river, curents........ 109

Yaqui river, fogs

Yaqui river, fogs............ 109

Yapala point_............... 140

Yapala point, anchorage _....... 140

Yapala point, landing -......... $\quad 140$

Yapala point, supplies......... 140

Yapala point, village _... . . . . 140

Ysatan point _.............. 139 


\section{LIST OF HYDROGRAPHIC OFFICE PUBLICATIONS, ETC.}

\begin{tabular}{l|l} 
No. & TITLE OF BOOK.
\end{tabular}

\section{NORTH ATLANTIC OCEAN.}

General examination of the Atlantic ocean. By Capt. Charles Phillippe De Kerballet Translated by Capt. R. H. Wyman, U. S. N. 8vo. 1870. Hyılrographic Office _.

Supplement No. 1. 1886 . Hydrographic Office
General directions for the Atlantic ocean. From the French of F. Lacrosse. Translated by Lient. Commander J. B. Coghlan, U. S. N. 8ro. 1873. Hydrographic Office. Second edition ...............

Nova Scotia, bay of Fundy, and south shore of gulf of St. Lawrence. Compiled by R. H. Orr. 8vo. 1891. Hydrographic Office.........

Gulf and river St. Lawrence and Cape Briton island. Compiled by R. H. Orr. 8vo. 1891 . Hydrographic Office

The navigation of the Caribbean sea and the gulf of Mexico. Vol. I.
The West India islands, including the liahama banks and islands, and the Bernuda islands. Compiled bs R. C. Ray, U. S. N. 8vo.

1892. Hydrographic Office. Third erlition
The navigation of the Caribbean s+a and the gulf of Mexico. Vol. II. Coasts from the Rio Grande ciel Norte to cape Orange with adjacent islands and dangers. Revised by R. C. Ray, U S. N. 8vo. 1890. Hydrographic Oftice......... Supplement. 1891.0 Gulf coast of the United States. Compiled Supplement No. 2. Gulf coast of the United States. Compiled
loy Lieut. W. s. Hughes, U. S. N. 8vo. 1891. Hyrlographic Office

Newfoundland and Labrador. Compiled by Lieut. W. W. Gilpatrick and Ensign John Gilson, U.S. N. 8vo. 1884. Hydrographic Office.

Newfoundland and Labrador. Supplement. 8vo. 18-6. Compiled by Lieut. R. G. Davenport and Ensign John Gibson, U. S. N. Hydrographic Office........... Supplement No. 2. 1891 . Hydrographic Office

Sailing directions for the Kattegat sound, and the Great and Little belts to the Baltic sea. Compiled by Commander Willian Gibson, U. S. N. 8vo. 1881. Hydrographic Oftice ....... Supplement No. 1. 1886 . Hydrographic Office

Sailing directions for the Encrlish channel. Part I. South coast of England. 8vo. 1872. Hydrographic Office ..................... Supplement. Second edition. 1889. Hydrographic Office..... Supplement No. 2. 1891. Hydrographic Office .............. Sailing directions for the English channel. Part II. Compiled by Master Asher C. Baker, U. S. N. 8vo. 18Ti. Hydrograplic Office. Supplement. Second edition. 1889. Hydrographic Uftice..... Supplement No.2. 1892. Hydrographic () ficice Coasts and ports of the bay of Biscay. Translated and compiled by Lients. G. M. Totten and Seaton sichroeder, U. S. N. 8vo. $1876^{\circ}$ Hydrographic Office _. supplement. 'I hird edition. 1892. Hy loographic Otfice ......

Winds, currents, and navigation of the gulf of Cadiz, the western coast of the Spanish Peninsula, and the strait of Gibraitar. By Capt. R. H. Wyman, U. S. N. 8vo. 1870. Hydrographic Othice

Northwest, west, and soutl coasts of Spain. and the coast of Portingal from point Estaca to cape Trafal gar. Translated and compiled hy Liut. George M. Totter, U. s.. N. 8ro. 1874. Hylrographic Office

Supplentent. Second edition. 1890 . Hrolrographic Uttice...... 


No. $\quad$ TITLE OF BOUK.

\section{NORTH ATL.INTIC OCEAN-CONTINUED.}

General examination of the Mediterranean'sea. By Capt. A. Le Gras, I. F. N. 'Translated by Capt. R. H. Wyman, U. S. N. 8vo. 1870. Hydrographic Office.

Mediterranean. PartI. South and SE. coasts of Spain from Mala Bahia to cape Creux. Balearic islands and north coast of Africa from Ceuta to La Cala. Translated and compiled by Lieut Commander H. H. Gorringe, U. S. N. 8vo. 1875. Hydrographic Office............. Supplement. 'Third edition. 1892. Hydrographic Office.......

Mediterranean. Part II. South coast of France, west coast of Italy, Tuscan archipelago, Corsica, and Sardinia. By Lieut. Commander H. H. Gorringe, U. S. N., assisted by Lieut Seaton Schroeder, U. S. N. 8vo. 1878. Hydrographic Office _. Supplement. Third edition. 1892. Hydrographic Office

Mediterranean. Part III. Coast of Tunis; Sardinia; Sicily; and Malta channels ; Lipari islands; Sicily; strait of Messina ; coast of Tripoli ; coast of Egypt; Syria. By Lient. Comniander H. H. Gorringe, U. S. N., assisted by Lieut. Seaton Schroeder, U. S. N. 8vo. 1879. Hydrographic Office _ ............ Supplement. Third edition. 1892. Hydrographic Uttice.........

Mediterranean. Part IV. Gnlf of Gioja to cape Santa Maria di Leuca, south coast of Italy, the Adriatic sea, Ionian islands, the coasts of Albania and Greece to cape Malea, with Cerigo island, including the gulfs of Patras and Corinth. 1883. Hydrographic Office -...... Supplement. 'Third edition. 1892. Hydrographic Office....

The Azores, Madeira, Canaries, and Cape Verde islands. Compiled by R. C. Ray, U. s. N. 8vo. 1892. Hydrographic Office..........

The West coast of Africa. Part I. From cape Spartel to Sierra Leone. Translated and compiled by Lieut. Commander H. H Gorringe, U. S. N. 8vo. 1873. Hydrographic Office ....... Supplement. 1886. Hydrographic Office..............

The West Coast of Africa. Part II. From Sierra Leone to Cape Lopez. Translated and compiled by Lieut. L. Chenery, U. S. N. 8vo. 1875. Hydrographic Office Supplement. 1886 Hydrographic Otfice.

Papers on the eastern and northern extension of the Gulf stream. From the German of Dr. A. Peterman, Dr. W. Von Freeden, and Dr. A. Mühry. 'Translated by E. R. Knorr. 4to. 1871. Hydrographic Office

First, second, third, fourth, fifth, and sixth supplements to papers on the eastern and northeru extension of the Gulf stream. (Pamphlets ) 1872-75. Hydrographic Office

Memoir of the dangers and ice in the north Atlantic. (Pamphlet.) 1868. Bureau of Navigation ...

Ice and ice movements in north Atlantic oceall. By Ensign Hugh Rodman, U. S. N. (Pamphlet.) 1890. Hydrographic Office .......

\section{SOU'TH A'TLANTHC OCEAN.}

The west coast of Africa. Part III. From cape. Lopez to the cape of Good Hope, iucluding the islands in the bight of Biafra, and Ascension and St. Helena islands. Translated and compiled by Lieut. Commander J. R. liartlett, U. S. N. 8vo. 1877. Hydrographic Office.

Supplement. Second edition. 1892. Hydrographic Office-_._.-

The east coast of South America. From cape i)range to cape Virgius, including Faulkland, South Georgia, Sandwich, and Soutl Shetland islands. Compiled by R. H. Orr. 8vo. 1889. Hydrographic Office . . . . Supplement. 1891. Hydrographic Office

The Rio de la Plata. 'Translated and compiled by Lient. Commander H. H. Gorringe, U. S. N. 8vo. 1875. Hydrographic Othice ........ Supplement No. 1. 1886. Hydrographic Office 


\section{SOUTH A'TLINTIC O)CE.I.Y-CONTINEED.}

Navigation of the strait of Magellan. Trans'ated from the French by Commodore J. C. P. de Krafft and Conmander William Gibsom, U. S. N. 1883. Hydrographic Office

Remarks by Capt. M. A. Lef evre, of the Flench Navy, on the voyage of the Vaudreuil through the Patagonian channels and Magellan strait. Translated by Lieut. George M. Totten, U. S. N. (Pamphlet.) 1874. Hydrographic Office.

\section{PACIFIC OCEAN.}

General examination of the Pacific ocean. By Capt. Charles Plitlippe De Kerhallet, French Imperial Navy. 'Translated nuder the direction of Conımodore Charles Henry Davis, U. S. N. 8vo. 1867. Supplement No. 1. 1886. Hydrographic Office....................

The navigation of the Pacific ocean. Translated from the French of Mons. F. Labrosse, by Lieut. J. W. Miller, U. S. N. 8vo. 1874. Hydrographic Office. (Republication, 1893.)

The west coast of South America, including Magellan strait, Tierra del Fuego, and the outlying islands. Compiled by R. C. Ray, U. ¿.

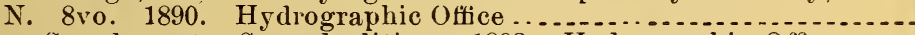
Supplement. Second edition. 1892. Hydrographic Office.....

West coast of Mexico and Central America, from the United States to Panama, including the grulfs of California and Panama. Compiled by R. C. Ray, U. S. N. 1893. Hydrographic Office.

The coast of British Columbia. From Juan de Fuca strait to Portland canal, including Vancouver and Queen Cliarlotte islands. Compiled by R. C. Ray, U. S. N. 8vo. 1891. Hydrographic Office..

Supplement. 1891. Hydrographic Office.....................

Directory for coast of Alaska and Bering sea. 8vo. Bureau of Navigation. (Edition exhausted.)

List of reported dangers in the North Pacific ocean. 8vo. 1871. Hydrographic Office......

Supplement to reported dangers in the north Pacific ocean. Compiled and arranged by Commander Wm. Gibson, U.S. N. 8vo. 1880. Hydrographic Office

List of reported langers in the south Pacific ocean. Compilerl and arranged by Lieut. J. E. Pillsbury, U. S. N. 8vo. 1879. Hydrographic Office

Supplement. 1891. Hydrographic Office $\ldots \ldots \ldots \ldots$

Ice and ice movements in Bering sea and the Arctic basin. By Ensign E. Simpson, U. S. N? (Pamphlet.) 1890. Hydrographic Office.

\section{INDIAN OCEAN.}

Sailing directions of the Indian ocean, the winds, monsoons. currents, and passage, inclnding also the Java sea, Sulu sea, Afuera sea, and the Philippine islands. Compiled by Lieut. F E. Sanyer,

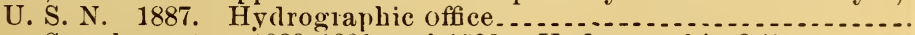

Sinplements. 1889,1890, and 1892. Hydrographic Ottice....... General examination of Indian ocean, with directions for the ravigation of 'Torres strait, etc. By Capt. Charles Plillippe De Kerhallet, I. F. N. Translated by Capt. K. H. Wyman, U. S. N. 8vo. 1870. Hydlographic Office iV. Krop, I. A. N. Translated by F. R. Knorr. 8vo. 1872. Hydrographic Office

\section{LIGHT LISTS.}

List of lights (No. 1) of North and Sonth America (excepting the United States), inclnding the West Indies and Pacific islands. 8 vo. 1893. Hydrographic Oftice 


\section{LIGIIT LISTS-CoNTNEED.}

74 List of lights (No. 5) of the Morth, Baltic, and White seas, including the coasts of Denmark, Prussia, Russia, sweden, and Norway. 8vo. Hydrographic Otfice of the Bitish islands. 8vo. Hydrographic Office. (Edition exhansted) Portugal France. Belginm, and Holland. 8vo. Hydrographic Uffice. (Edition exhausted)

List of lights (No. 3) of the west cuast of Africa and the Mediterranean sea, including the west and north coasts of Africa, the Mediterranean, the Adriatic, the Black seas, and the sea of Azof. 8vo. Hydrographic (Iffice

Supplement, 1890 . Hydrumaphic (1ttice

List of lights ( No. 2) of sonth and east coasts of Africa, and the East Indies, inchnding the East India islands, China, Japan, Australia, Tasmania, and New Zealand. 8vo. Hydrographic Oftice

\section{NAVIGATION BOOKS.}

72 List of geographical positions. By Lient Commander F. M. Green,

9 The New Anerican practical navigator. By Nathaniel Bowditch,

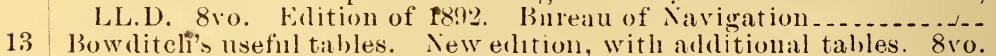
1892. Bnrean of Navigation _... . . . . .

17 Projection tables. 8vo. 1869. Burean of Xiveation..............

71 Azimuth tables for parallels of latitude betwe n $61^{\circ} \mathrm{X}$. and $61^{\circ} \mathrm{s}$. By Lient. IV. H. H. sontherland. U. S. N. 1883. Hydrographic office--

66 Arctic azimuth tables for parallels of latitule between $70^{\circ}$ and $88^{\circ}$. Preparen by Lients. Seaton Schroeder and R chard Wainwright, U. s. N. 12mo. 1881. Hydrographic Otfice......................

57 Tables for finding the distance of an object by two hearings. (Panphlet) 1874. Hyilographic oftice........

49 The romte of mail steaners hetween the Finglish channel and New York. 1873. (Pamph et) Hydrographic Othice.................

90 The development of great circle sailing. liv G. WV. Littlehaies. $8 \mathrm{rog}$

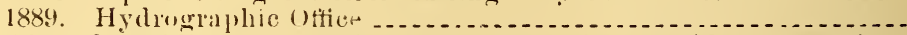

91 Tables of meridional parts for the terrestrial spheroid, compression

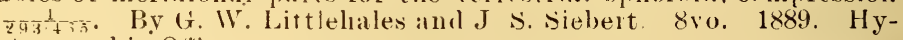
drographic Oftice ...

\section{COMHASSES AND DEVIAIION.}

8 Magrietism of ships and the deviations of the compass. Br Poisson, Airy, Smith, Evans. and liandall. with other papers and documents. Edited by B. Franklin Green. 8ro. 1867. Bnean of Navigation..

Magnetism of ships and the deriations of the compass. Comprising the three reports of the Liverpool Com!pass Commission, with additional papers by Mr. Archibald -mith. F. R. S., etc. and Staff-Captain F. J. Lvans, R. . . 8vo. 1869. Bnrean of Navigation ........

19 Ship's compasses, inchinding the snbject of binnacles and swingmg ships. By Cominodore T. A. Jenkins, U S. N. 8vo. 1869. Bureaul of Navigation . . .

62 Finding the compass error on board ship By B. F. Green. professor of mathematics, U. S. N. 8 V.. 1875. Burean of Naviqation......

\section{MEI'EOROLOGICAL.}

4 The way to aroid the center of our violent gales. 8ro. 1868. Bu-

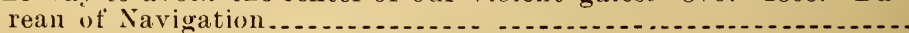

77 Practical hints in regard to West India hinricanes. By Lieut. G. L. Dyer. U. S. N. 1887. (Pamphlet) Hydrographic Office .......... Nantical monograph No. $_{5}$. The great storm off the Atlantic coast of the Uniterl States, March 11-14, 1888. By Everett Hay, U. S. N.

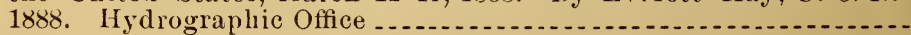


No.

$-$

General instructions for hydrographic surveyors. (Pamplilets.) 1868. Bureau of Navigation . . . .

The methods and results of the survey of the west coast of lower California by the officers of the U.S. S. Ranger during the season of 1889 and 1890. By Lieut. O. W. Lowry, U. S. N., and (x. W. Little-

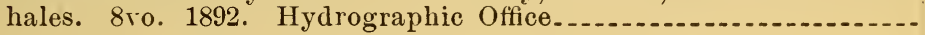

PRICE.

\section{SIGNALS.}

International signal code. Revised and corrected to 1890, including the semaphore and storm-signal service of the maritime countries, the life-saving service and time-ball system of the United States. Prepared by Lieut. Chas. M. McCarteney, U. S. N. 8vo. 1890. Bu-

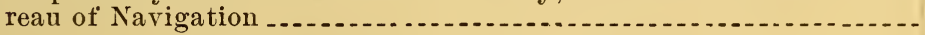

\section{MISCELLANEOUS PUBLICATIONS.}

U. S. Hodrographic Office papers. Occasional publications, 1 to $6 \ldots$ Report on the telegraphic determination of differences of longitude in the West Indies and Central Anerica. By Lieut. Commander F. M. Green, U. S. N. 4to. 1877. Bureall of Navigation................

Report on the telegraphic determination of difference of longitude on the "east coast of South America. By Lient. Commander F. M. Green, U. S. N. 4to. 1880. Bureau of Navigation

Report on the telegraphic deternination of longitude in the East Indies, China, and Japan. By Lieut. Commander F. M. Green, U. S. N.

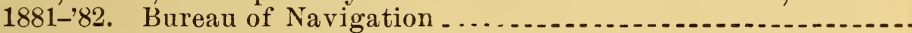

Report of telegraphic determinations of longitudes in Mexico, Central America, and west coast of South America. By Lieut. Commander C. H. Davis, Lieuts. J. A. Norris, and Charles Laird, U. S. N. 1885 . Bureau of Navigation

Report on the telegraphic determination of longitudes in Mexico, Central America, the West Indies, and on the north coast of South A merica, with the latitudes of the several stations. By Lients. J. A. Norris and Charles Laird, U. S. N. To which is appended a report on magnetic observations in Mexico and the West Indies. By Lient. Charles Laird and Ensigns J. H. L. Holcombe and L. M. Garrett, U. S. N. 1891. Bureau of Navigation .......................

Report of the International Meteorologic Congress at Paris, 18×9. By Lieut. Aaron Ward, U. S. N. (Pamplilet.) 1890

The average form of isolated subnarine peaks and the interval which should obtain between deep-sea soundings taken to disclose the character of the bottom of the ocean. By G. W. Littleliales. 8vo. 1890. Hydrographic Office

Report on uniform system fur spelling foreign geographic names. By Lieut. C. 1". McCartenes, U. S. N:, Boynton Leach, and Gustave Herrle. (Pamphlet.) 1891. Hydrographic (office.

103 Submarine cables. Instruments and implements employed in cable surveys; theory of cable laying; specifications and costs; submarine cable systens of the world. Prepared by G. W. Littlehales. 8vo. 1892. Hydrographic Office Atlantic and Gulf coasts of the United States. Prepared by Gustave

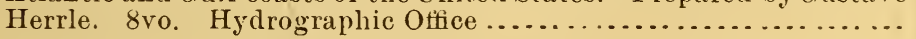




\title{
AGENTS FOR THL SALE OF HYDROGRAPHIC OFFICE CHARTS, SAILING DIRECTIONS, ETC.
}

\author{
AGENTS IN UNITED STÁTES.
}

C. H. Cummings, Eastport, Me.

N. C. Wallace, Millbridge, Me.

Albert W. Bee, Bar Harbor, Me.

Spear, May \& Stover, 408 Main street, Rockland, Me.

George Bliss, Waldoborough, Me.

William O. McCobb, Booth Bay Harbor, Me.

Charles A. Harriman, Bath, Me.

William Senter \& Co., No. 51 Exchange street, Portland, Me.

P. A. Chisolm, No. 161 Main street, Gloucester, Mass.

Henry P. Ives, 232 Essex street, Salem, Mass.

Chas. C. Hutchinson, No. 126 Commercial street, Boston, Mass.

Samuel Thaxter \& Son, No. 125 State street, Boston, Mass.

D. W. Stevens, Viueyard Haven. Mass.

C. R. Sherman \& Son, New Bedford, Mass.

Geo. A. Stockwell, Providence, R. I.

J. M. K. Southwick, 185 Thames street, Newport, R. I.

C. C. Ball, Block Island.

D. B. Hempsted, 25 Bank street, New Londou, Conn.

Seargt. P. Daniels, New London, Conn.

Jas. H. Stivers, 72 Water street, Stonington, Conn.

R. D. Stevens, Customhouse, Hartford, Conn.

H. H. Babcock, Customhouse, New Haven, Conn.

A. H. Kellam, New Haven, Conn.

T. S. \& J. D. Negus, No. 140 Water street, New York City.

R. Merrill's Sons, 179 Water street, New York City.

Michael Rupp \& Co., No. 39, South street, New York City.

E. Eggert's Sons, No. 74 Wall street, New York City.

John Bliss \& Co., No. 128 Front street, New York City.

Thomas Manning, No. 53 Beaver street, New York City.

E. Steiger \& Co., 25 Park place, New York City.

Thomas S. Faulkner, Emigrant Clearing House, Ellis Island, N. Y.

Frank M. Porch, Custo̊nhouse, Bridgeton, N. J.

Riggs \& Bro., No. 221 Walnut street, Philadelphia, Pa.

F. J. Sloane \& Co., cor. Pratt street and Speer's wharf, Baltimore, Md.

M. V. O'Neal, No. 502 East Pratt street, Baltimore, Md.

C. C. Lapsley, 53 South Gay street, Baltimore, Md.

J. J. Chapman, No. 915 Pennsylvania avenue, Washington, D. C.

W. H. Lowdermilk \& Co., $1424 \mathrm{~F}$ street $\mathrm{NW}$., Washington, D. C.

J. H. Hickcox, 906 M street NW., Washington, D. C.

R. Bell's Sons, South Fairfax street. Alexandria, Va.

C. F. Greenwood \& Bro., 158 Main street, Norfolk, Va. 
Vickery \& Co., 124 Main street, Norfolk, Va.

Godfrey Hart, No. 24 South Front street, Wilmington, N. C.

W. N. Harriss, with Geo. Harriss \& Co., North Water street, Wilmington N. C

W. B. Wilson, No. 115 East Bay street, Charleston, S. C.

J. P. Johnson, Customhouse, Savannah, Ga.

W. S. Cherry \& Co., No. 89 Bay street, Savannah, Ga.

T. W. Howell, Customhouse, Fernandina, Fla.

Horace Drew, Jacksonville, Fla.

Robert Ranson, Titusville, Fla.

Brelsford Bros., Paln Beach, Fla.

Alfred Brost, office of lighthouse inspector, Key West, Fla.

Babbitt \& Co., Franklin street, Tampa, Fla.

C. D. Webster, 83 and 85 Tarpon avenue, Tarpon Springs, Fla.

J. E. Grady, Apalachicola, Fla.

Henry Horsler \& Co., 706 and 708 South Palafox street, Pensacola, Fla.

McKenzie,Oerting \& Co., 599 Palafox street, Pensacola, Fla.

J. R. Edwards, Mobile, Ala.

Chamberlain \& Co., Mobile, Ala.

Jas. I. Friar, Pascagoula, Miss.

L. Frigerio, No. 161 Canal street, New Orleans, La.

Frigerio \& Schully, 85 Royal street, New Orleans, La.

Woodward, Wight \& Co., Nos. 38, 40, 42 Canal street, New Orleans, La

Chas. F. Trube, Galveston, Tex.

Rand, McNally \& Co., 148-154 Monroe street, Chicago, Ill.

Dodge \& Burbeck, cor. Fifth and D streets, San Diego, Cal.

W. L. Banning, San Pedro, Cal.

Stoll \& Thayer Co., 139 Sonth Spring street, Los Angeles, Cal.

H. A. C. McPhail, Santa Barbara, Cal.

S. S. Arnheim, No. 8 Stuart street, San Francisco, Cal.

Dillon \& Co., No. 310 California street, San Francisco, Cal.

Louis Weule, No. 418 Battery street, San Francisco, Cal.

Griffen \& Reed, Astoria, Oregon.

James E. Matthews, Eurreka, Humboldt county, Cal.

J. K. Gill \& Co., Nos. 28 and 30 First street, Portland, Oregon.

James Jones, Port Townsend, Wash.

Waterman \& Katz, Port Townsend, Wash.

Vaughan \& Morrill, Tacoma, Wash.

Boeringer \& Co., Tacoma, Wash.

Lowman \& Hanford, Seattle, Wash.

W. H. Pumphres, Seattle, Wash.

AGENTS IN FOREIGN PORTS.

Garrett Byrne, St. Johns, Newfoundland.

Alexander Bain, Port Hawkesbury, Nova Scotia.

Robert H. Cogswell, Halifax, Nova Scotia.

J. \& A. McMillan, St. John, New Brunswick.

Hunter \& Grant, Hamilton, Ontario.

T. Darling \& Co., Nassau, Bahamas.

E. J. D. Astwood, Turks Island.

Edwin W. Wilson, 41 and 43 Obispo street, Havana, Cuba.

Juan B. Carbo, United States Vice-Consul, Cienfuegos, Cuba.

J. P. Thorsen, St. Thomas, West Indies.

James Gall, Kingston, Jamaica.

G. Anciaux, United States Consulate, Barbados, West Indies.

John A. Donnatien, Port Spain, Trinidad, West Indies. 
Para, Brazil, at the consulate.

$\Lambda$ rthur B. Dallas, Pernambuco, Brazil.

St. Helena Island, at the consulate.

John Newton, 2 Calle de la Constitucion, Callao, Peru.

F. A. Markert, Guaymas, Mexico.

M. W. Waitt \& Co., 77 Government street, Victoria, British Columbia. Philip, Son \& Nephew, 41 to 51 South Castle street, Liverpool, England. Alexander Dobbie \& Son, 18 Clyde Place, Glasgow, Scotland.

V. \& M. Lepetit, 15 Rue de Paris, Havre, France.

G. W. Lohmann, Schliefmuhle 21, Bremen, Germany.

Charles Gaupp \& Co., Hongkong, China.

Russell L. Webb, Manila, Philippine Islands. 


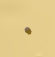

. - 




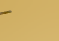

\section{.}

. 



.

$$
\text { , }
$$



